\title{
GUIDE TO RANGE PLANT COMMUNITY TYPES AND CARRYING CAPACITY FOR THE DRY AND CENTRAL MIXEDWOOD SUBREGIONS IN ALBERTA
}

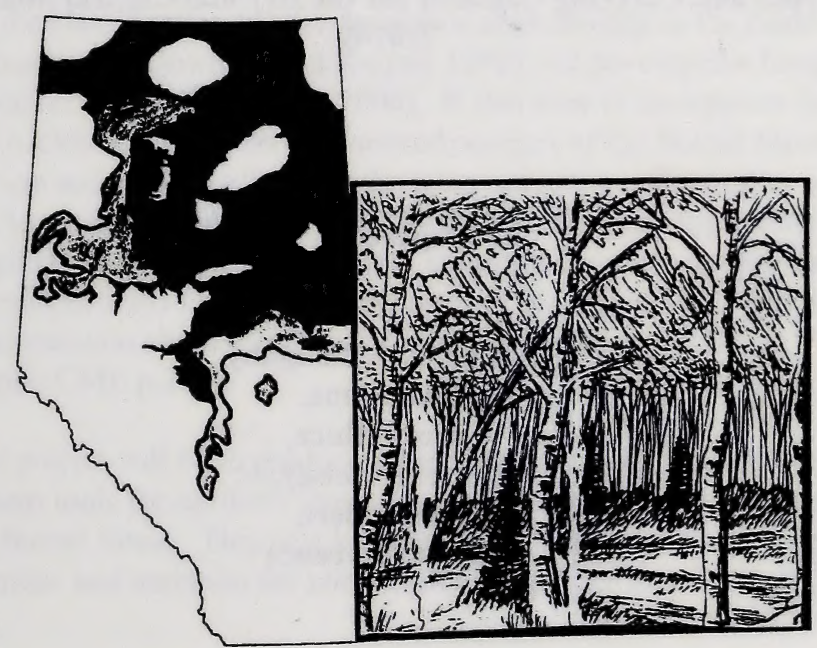

Alberra

SUSTAINABLE RESOURCE DEVELOPMENT

Public Lands $\&$ Forests 


\section{GUIDE TO RANGE PLANT COMMUNITY TYPES AND CARRYING CAPACITY FOR THE DRY AND CENTRAL MIXEDWOOD SUBREGIONS IN ALBERTA}

$$
6^{\text {th }} \text { approximation }
$$

(Please note this edition is a revision of the $5^{\text {th }}$ approximation of the Range Plant Community Types and Carrying Capacity for the Dry and Central Mixedwood Pub. No. T/074)

\section{Prepared by}

Michael G. Willoughby,

Colin Stone, Carcey Hincz, Darlene Moisey, Gerry Ehlert, Donna Lawrence 


\section{FORWARD}

In January, 1999 the Rangeland Health Assessment Project was initiated. Its purpose was to coordinate the development of rangeland health assessment methods and ecological site descriptions for both forested and grassland dominated rangelands in the province and transfer the new technology (awareness, information and tools) to livestock producers, staff and other stakeholders. This document "Range plant communities and carrying capacity for the Dry and Central Mixedwood subregions of Alberta, Sixth Approximation" is an effort to organize existing range plant community information for the Boreal Mixedwood subregions into an ecological framework, with the ultimate goal of developing ecological site descriptions as outlined in the Alberta Rangeland Health Task Group, Terms of Reference (1999). This guide encompasses the work of Karen Sundquist (who worked on previous approximations) and Dave Downing who developed the classification for the deciduous communities in the Eastern ecodistricts of the Dry Mixedwood (Downing and Karpuk 1992) and developed a forage gap analysis for the Mixedwood subregions (Downing 2000). It also tries to incorporate the work done by Beckingham and Archibald (1996) on the forested ecosites of the Boreal Mixedwood and work done by Thompson and Hansen (2004) on the lotic and lentic communities of the Mixedwood subregions. As we collect new research information, the sixth approximation will evolve into a range ecological site field guide. The sixth approximation has updated successional sequences of tame pastures in both the Dry and Central areas of the Mixedwood region. This approximation has new information about 4 cutblock community types in the Central Mixedwood area [see section CME p.232].

One major outcome of the project will be to produce ecological base information which will be used to develop management tools for northern livestock producers, resource managers and other stakeholders of Alberta's Boreal forest. This new knowledge will aide in the sustainable grazing of forested plant communities, and maintain the good health and proper functioning of these ecosystems. 
ISBN No. 0-7785-4538-5 (Printed Edition)

ISBN No. 0-7785-4539-3 (On-line Edition)

Pub No. T/103

For copies of this report contact:

Michael Willoughby

Public Lands and Forests Division(PLFD)

9920108 st, 9th Floor

Edmonton, Alta.

T5K2M 4

(403) $422-4598$

mike.willoughby@.gov.ab.ca

Darlene Moisey

PLFD

St. Paul, Alta.

(780) 645-6308

darlene.moisey@.gov.ab.ca

Donna Lawrence

PLFD

Barrhead, Alta.

(780) 374-8231

donna.lawrence@.gov.ab.ca

Colin Stone

PLFD

Peace River, Alta.

(780) 624-6116

colin.stone@.gov.ab.ca

Carcey Hincz

PLFD

Grande Prairie, Alta.

(780)538-8026

carcey.hincz@.gov.ab.ca 


\section{Table of Contents}

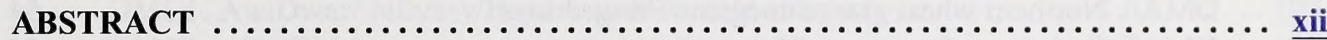

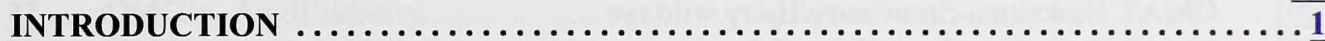

CLIMATE AND MODAL PLANT COMMUNITIES $\ldots \ldots \ldots \ldots \ldots \ldots \ldots \ldots \ldots, \ldots \ldots$

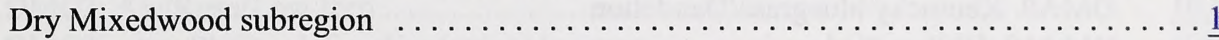

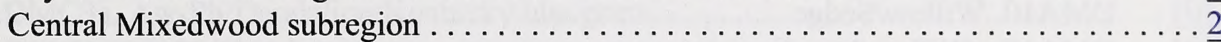

APPROACH AND METHODS OF CLASSIFICATION $\ldots \ldots \ldots \ldots \ldots \ldots \ldots \ldots, \ldots \ldots \ldots$

Approach: Ecological classification hierarchy and terminology $\ldots \ldots \ldots \ldots \ldots \ldots, \frac{3}{3}$

Methods: Plant community classification $\ldots \ldots \ldots \ldots \ldots \ldots \ldots \ldots \ldots \ldots \ldots \ldots \ldots \ldots$

RANGE MANAGEMENT CONCEPTS AND METHODS $\ldots \ldots \ldots \ldots \ldots \ldots \ldots \ldots, 6,6$

Ecologically sustainable stocking rates $\ldots \ldots \ldots \ldots \ldots \ldots \ldots \ldots \ldots \ldots \ldots \ldots \ldots \ldots, \underline{6}$

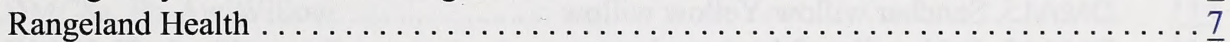

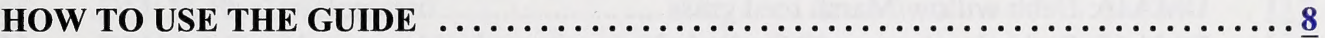

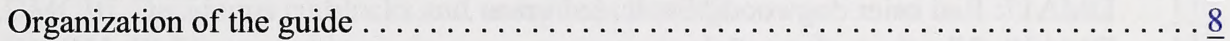

Identifying plant community types $\ldots \ldots \ldots \ldots \ldots \ldots \ldots \ldots \ldots \ldots \ldots \ldots \ldots \ldots$

Method 1. Use dichotomous key within dominant cover categories ........ 9

Method 2. Use edatope and indicator species $\ldots \ldots \ldots \ldots \ldots \ldots \ldots \ldots \ldots \ldots \ldots \ldots$

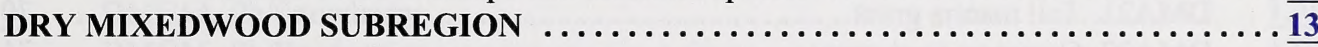

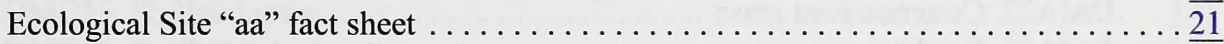

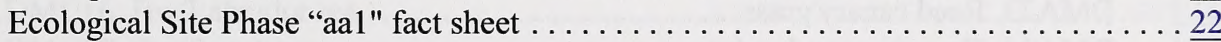

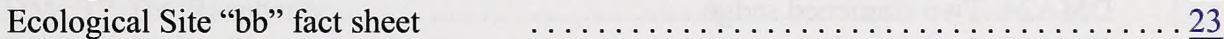

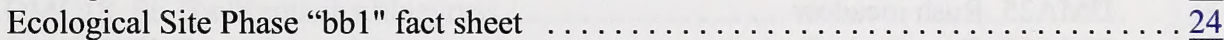

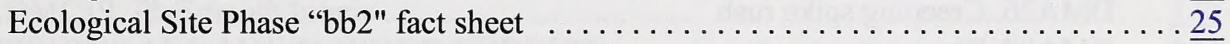

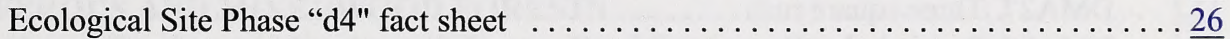

Ecological Site Phase "d1a" fact sheet . . . . . . . . . . . . . . . . . . . . . $\frac{27}{28}$

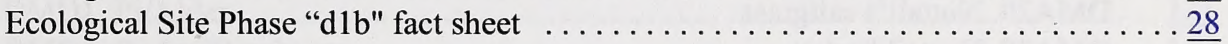

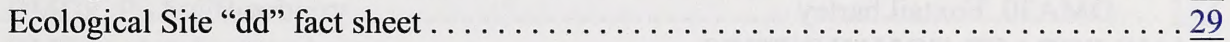

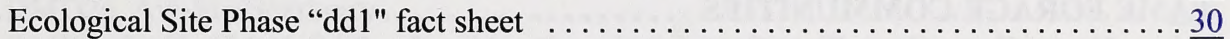

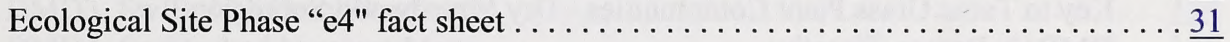

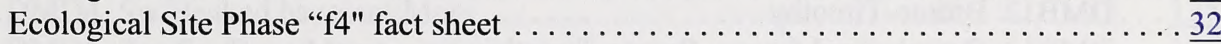

Ecological Site Phase "f5" fact sheet ........................... 33

Ecological Site Phase "g2" fact sheet . . . . . . . . . . . . . . . . . . . . . $\frac{34}{34}$

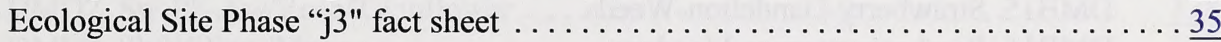

Ecological Site Phase "k2a" fact sheet ........................

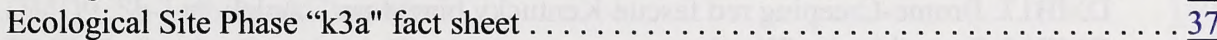

GRASSLAND AND SHRUBLAND COMMUNITY TYPES $\ldots \ldots \ldots \ldots \ldots \ldots \ldots \ldots, \mathbf{3 8}$

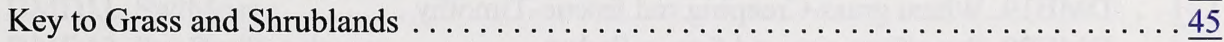

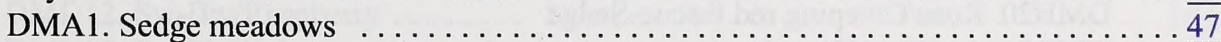

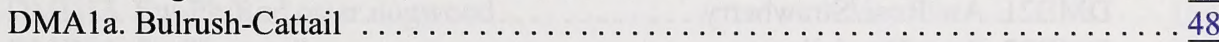

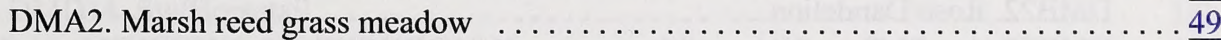

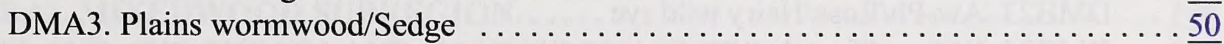

DMA4. Purple oat grass-Sedge-California oat grass $\ldots \ldots \ldots \ldots \ldots \ldots \ldots \ldots \underline{\underline{51}}$ 
DMA4a. Veiny meadow rue/Slender wheat grass-Fringed brome $\ldots \ldots \ldots \ldots \ldots \underline{52}$

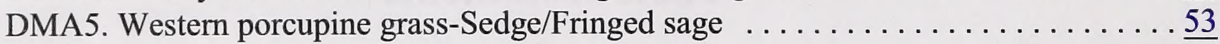

DMA6. Northern wheat grass-Junegrass/Fringed sage $\ldots \ldots \ldots \ldots \ldots \ldots \ldots \ldots \ldots \underline{54}$

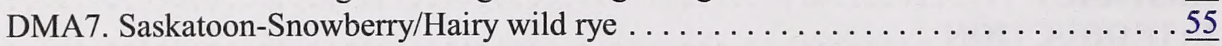

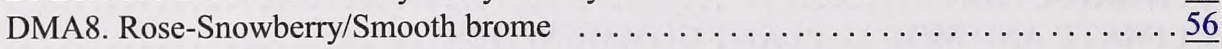

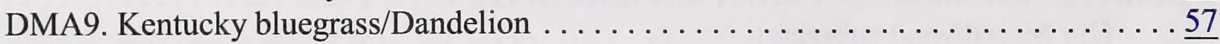

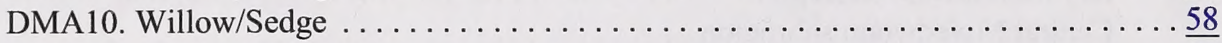

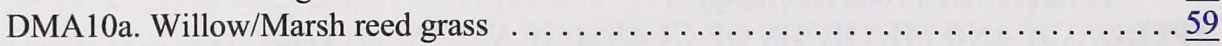

DMA11. Willow/Marsh reed grass-Kentucky bluegrass $\ldots \ldots \ldots \ldots \ldots \ldots \ldots \ldots \ldots \underline{\underline{60}}$

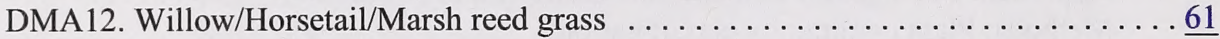

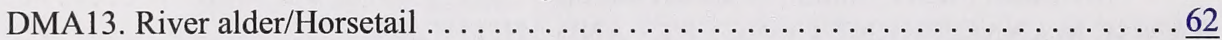

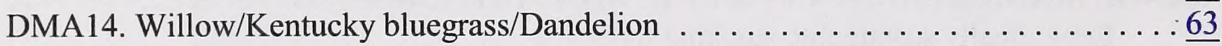

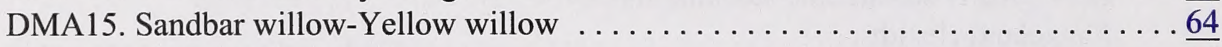

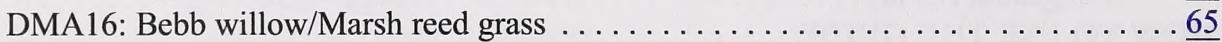

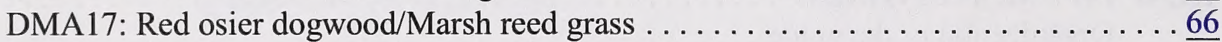

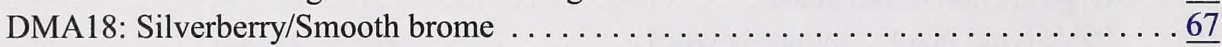

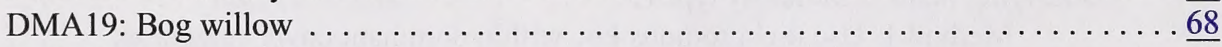

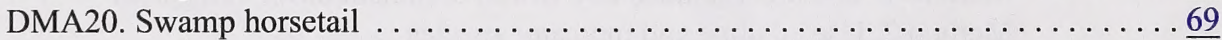

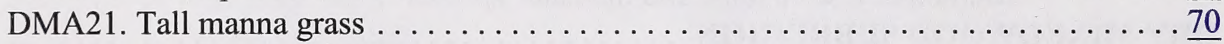

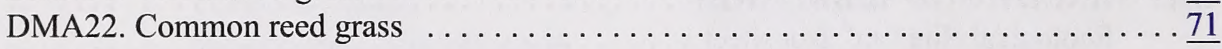

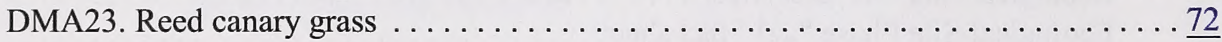

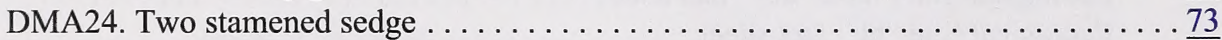

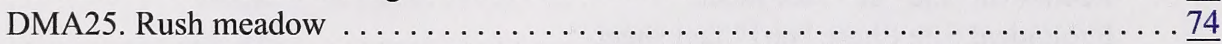

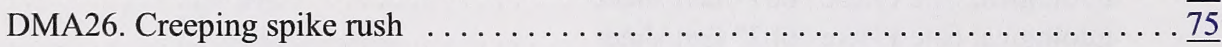

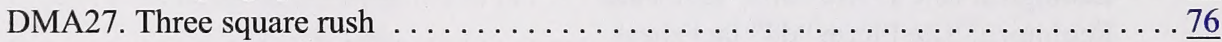

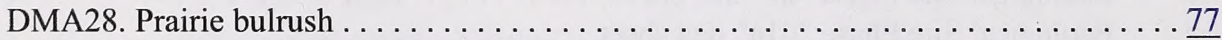

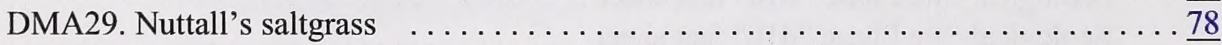

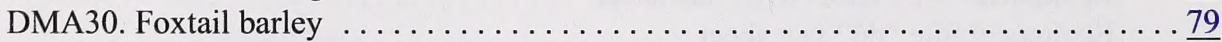

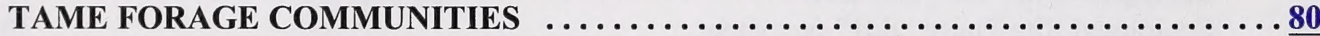

Key to Tame Grass Plant Communities - Dry Mixedwood Subregion . . . . . . $\frac{84}{84}$

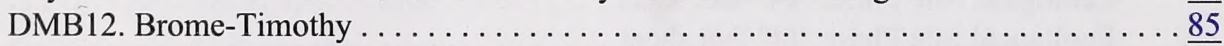

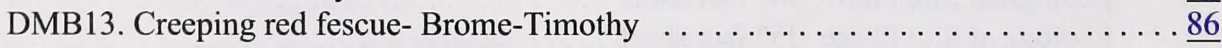

DMB14. Creeping red fescue-Kentucky bluegrass/Dandelion $\ldots \ldots \ldots \ldots \ldots \ldots \ldots 7$

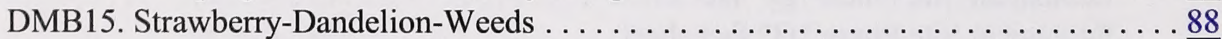

DMB16. Reed canary grass-Meadow $\ldots \ldots \ldots \ldots \ldots \ldots \ldots \ldots \ldots \ldots \ldots \ldots \ldots \ldots \ldots$

DMB17. Brome-Creeping red fescue-Kentucky bluegrass/Dandelion $\ldots \ldots \ldots \ldots \underline{\underline{90}}$

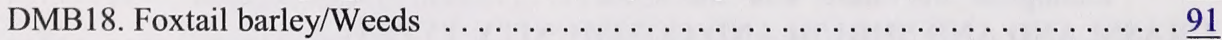

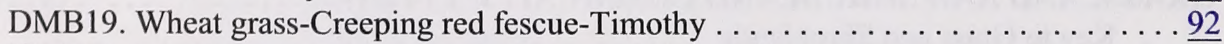

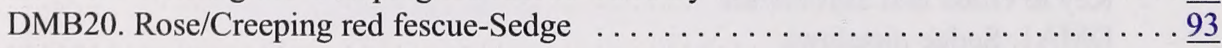

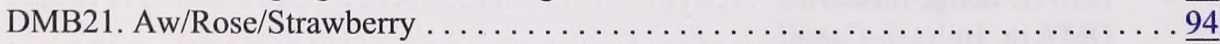

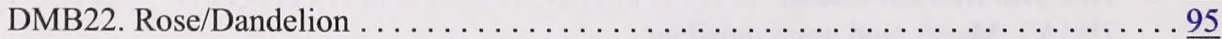

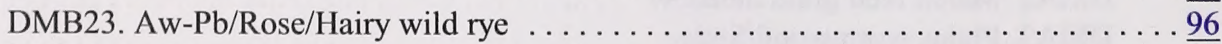

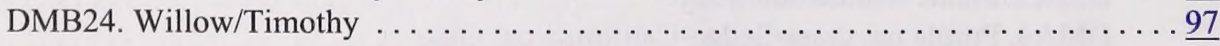




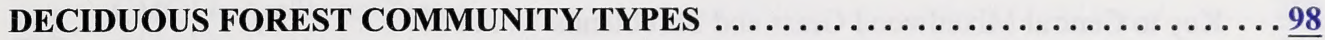

Key to Deciduous Community Types - Dry Mixedwood $\ldots \ldots \ldots \ldots \ldots \ldots \ldots \ldots \ldots \ldots$

DMC1. Aw/Dwarf bilberry/Bearberry/Mountain ricegrass $\ldots \ldots \ldots \ldots \ldots \ldots \ldots \underline{104}$

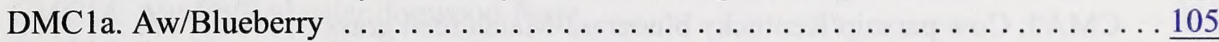

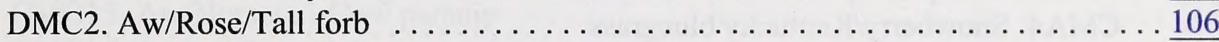

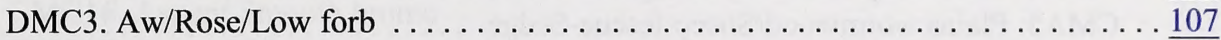

DMC3a. Aw-Pb/Dandelion/Kentucky bluegrass $\ldots \ldots \ldots \ldots \ldots \ldots \ldots \ldots \ldots \ldots \ldots$

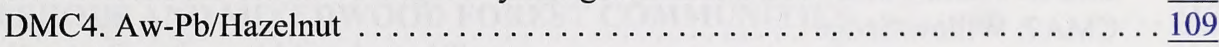

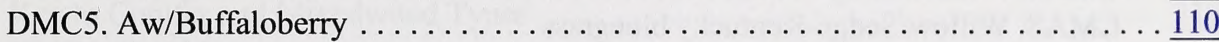

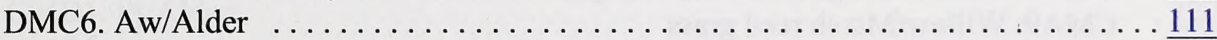

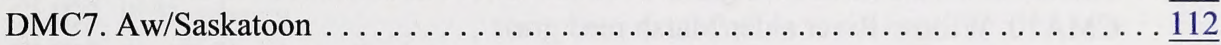

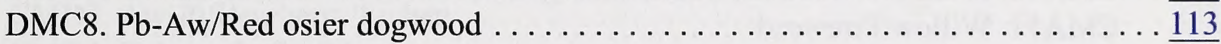

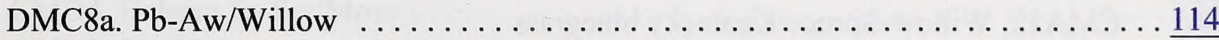

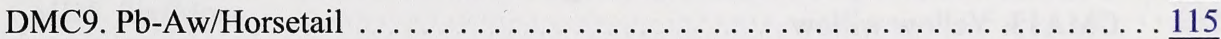

DMC10. Deciduous cutblocks and unseeded clearings $\ldots \ldots \ldots \ldots \ldots \ldots \ldots \ldots \ldots \ldots \ldots$

DMC11. Pb/Honeysuckle . . . . . . . . . . . . . . . . . . . . . . .

DMC12. Pb/River alder . . . . . . . . . . . . . . . . . . . . . . . . . 118

DMC13. Pb-Aw/Silverberry . . . . . . . . . . . . . . . . . . . . . . . . . $\frac{119}{119}$

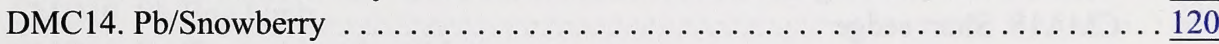

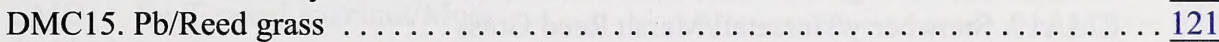

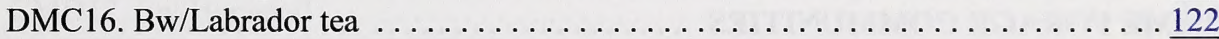

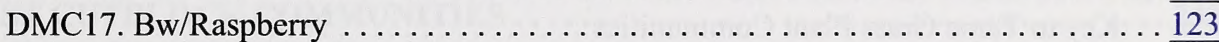

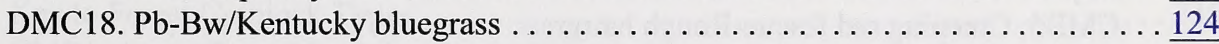

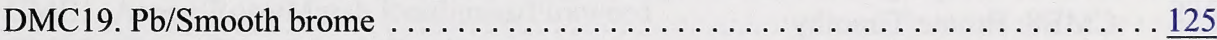

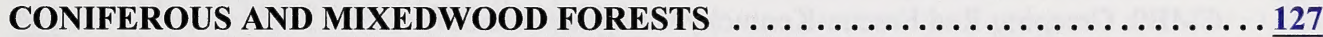

Key to Conifer and Mixedwood* Types - Dry Mixedwood $\ldots \ldots \ldots \ldots \ldots \ldots \ldots \ldots \ldots \ldots$

DMD1. Pj/Alder . . . . . . . . . . . . . . . . . . . . . . . . . .

DMD2. Pj-Aw/Bearberry . . . . . . . . . . . . . . . . . . . . . . .

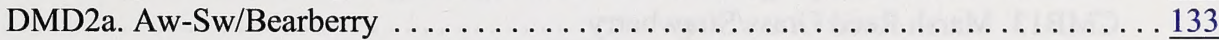

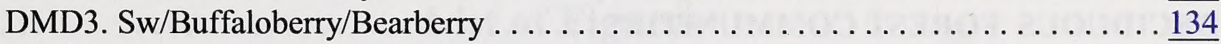

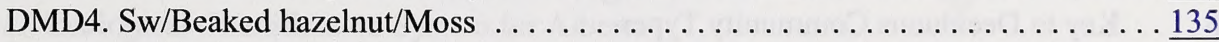

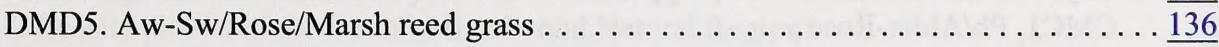

DMD6. Aw-Pb-Sw/Willow/Wild sarsaparilla . . . . . . . . . . . . . . . $\frac{137}{137}$

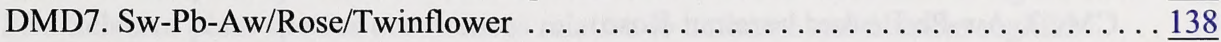

DMD8. Sb/Willow/Moss . . . . . . . . . . . . . . . . . . . . . . . . 139

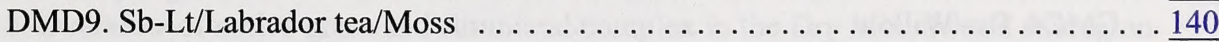

DMD10. Sw-Aw/Low bush Cranberry $\ldots \ldots \ldots \ldots \ldots \ldots \ldots \ldots \ldots \ldots \ldots \ldots \ldots \ldots \ldots \ldots \ldots$

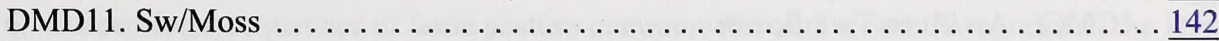

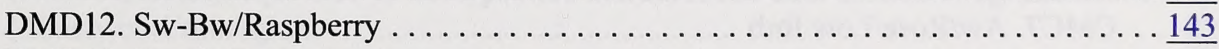

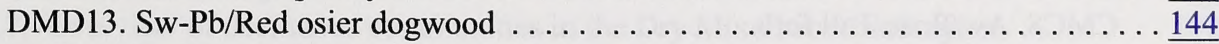

DMD14. Sw/Horsetail . . . . . . . . . . . . . . . . . . . . . . . . . 145

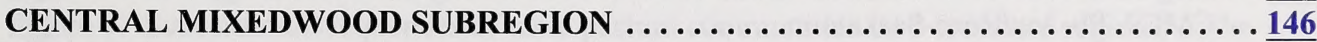

GRASSLAND AND SHRUBLAND COMMUNITY TYPES $\ldots \ldots \ldots \ldots \ldots \ldots \ldots, \underline{153}$ 


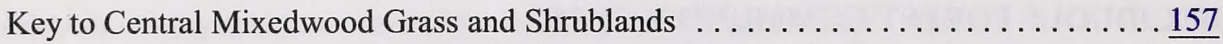

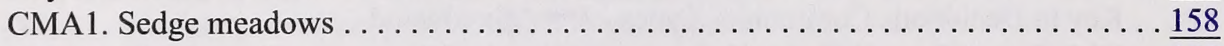

CMA2. Marsh reed grass meadow . . . . . . . . . . . . . . . . .

CMA3. Cow parsnip/Kentucky bluegrass-Marsh reed grass $\ldots \ldots \ldots \ldots \ldots \ldots \ldots \underline{160}$

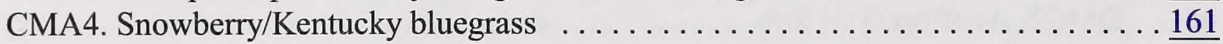

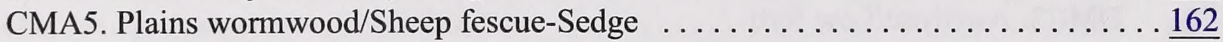

CMA6. Plains wormwood/Kentucky bluegrass-Sedge $\ldots \ldots \ldots \ldots \ldots \ldots \ldots \ldots \ldots \ldots \ldots$

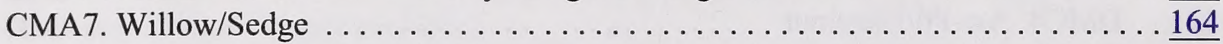

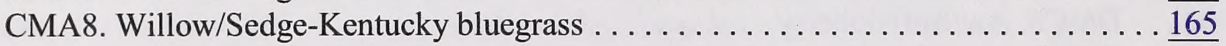

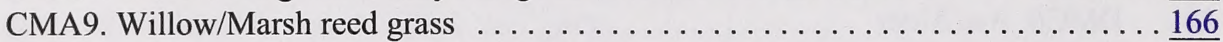

CMA10. Willow-River alder/Marsh reed grass $\ldots \ldots \ldots \ldots \ldots \ldots \ldots \ldots \ldots \ldots \ldots \ldots$

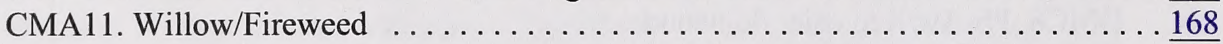

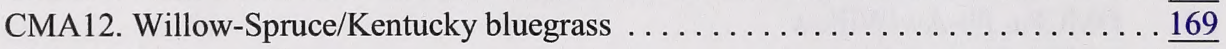

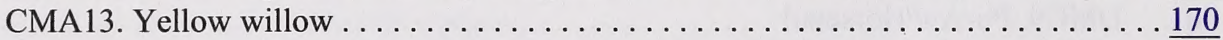

CMA14. Scouler willow-Red osier dogwood $\ldots \ldots \ldots \ldots \ldots \ldots \ldots \ldots \ldots \ldots \ldots \ldots$

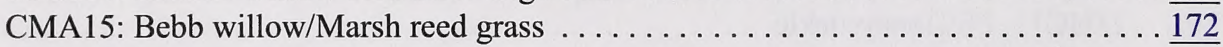

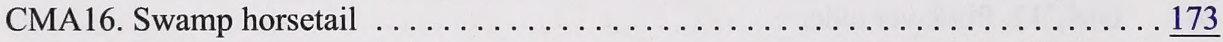

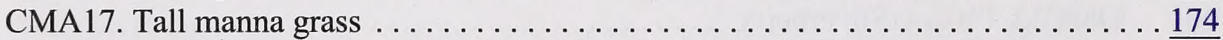

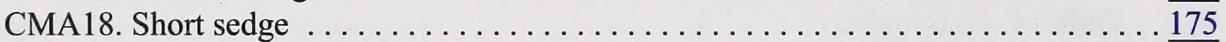

CMA19. Snowberry/Horsetail/Marsh Reed Grass . . . . . . . . . . . . $\frac{176}{176}$

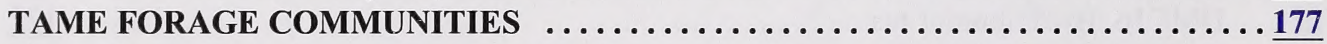

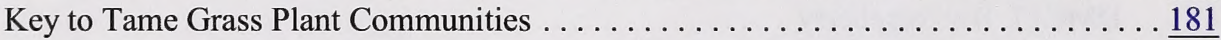

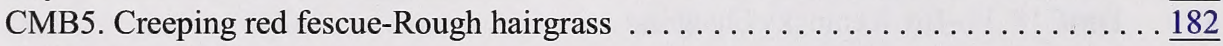

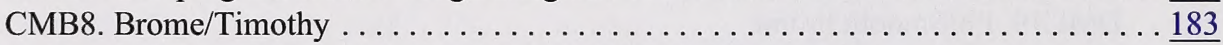

CMB9. Creeping Red Fescue-Kentucky Bluegrass-Timothy $\ldots \ldots \ldots \ldots \ldots \ldots \underline{184}$

CMB10. Creeping Red Fescue-Kentucky Bluegrass/Dandelion $\ldots \ldots \ldots \ldots \ldots \ldots \underline{185}$

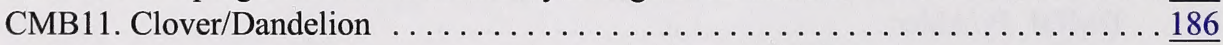

CMB12. Willow/Creeping red fescue/Kentucky Bluegrass $\ldots \ldots \ldots \ldots \ldots \ldots \ldots \underline{187}$

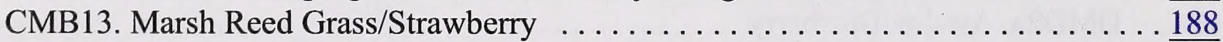

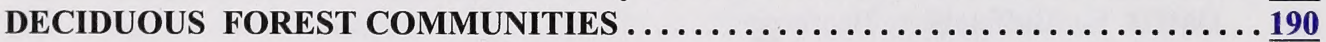

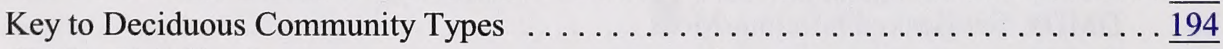

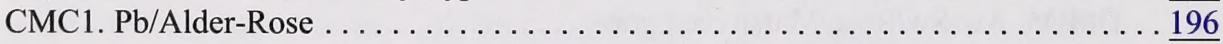

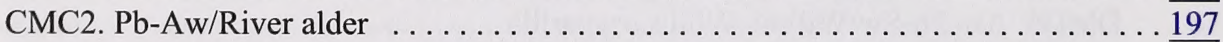

CMC3. Aw-Pb/Beaked hazelnut-Rose $\ldots \ldots \ldots \ldots \ldots \ldots \ldots \ldots \ldots \ldots \ldots \ldots \ldots$

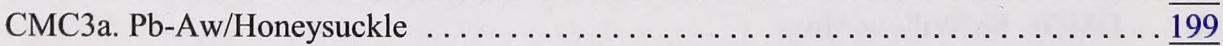

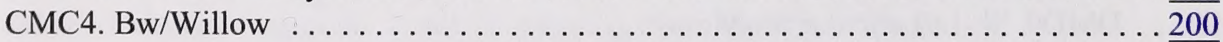

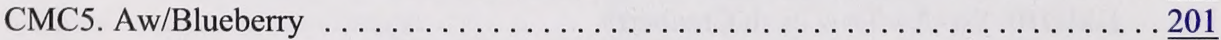

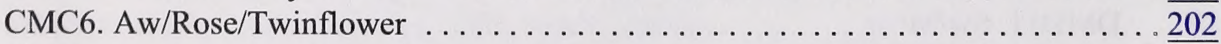

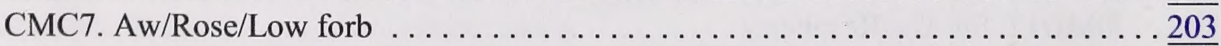

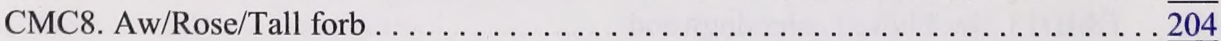

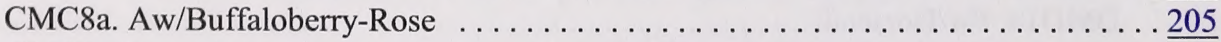

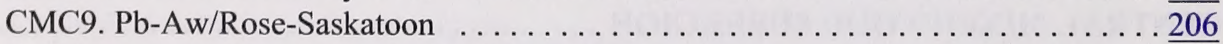

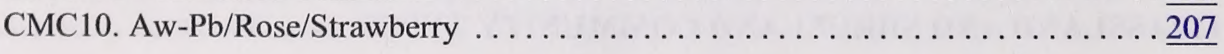




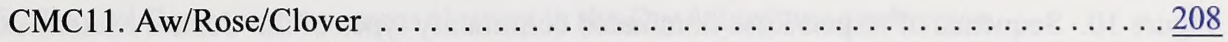

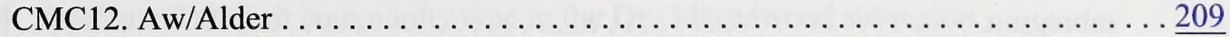

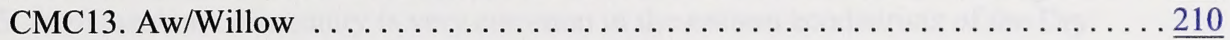

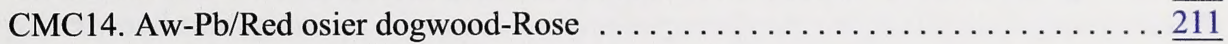

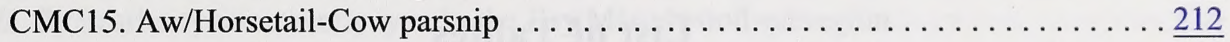

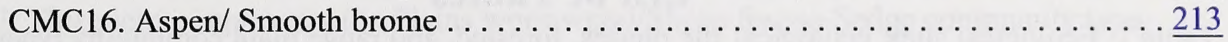

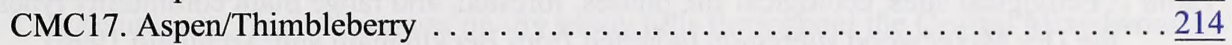

CONIFEROUS AND MIXEDWOOD FOREST COMMUNITIES $\ldots \ldots \ldots \ldots \ldots \ldots \ldots \underline{215}$

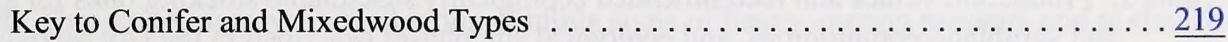

CMD1. Pj/Alder . . . . . . . . . . . .

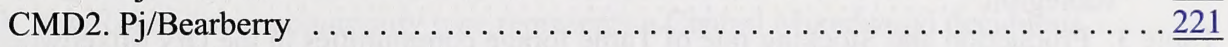

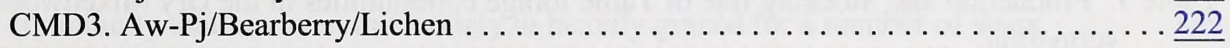

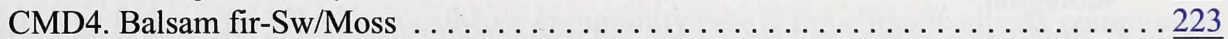

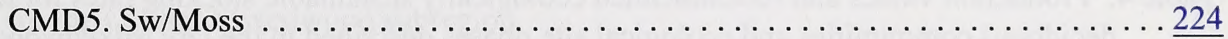

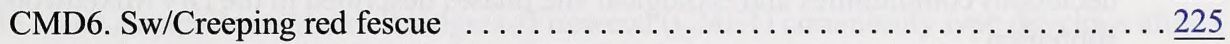

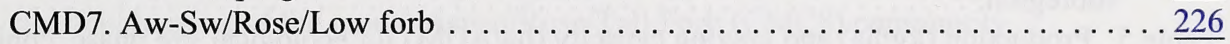

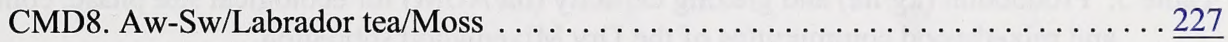

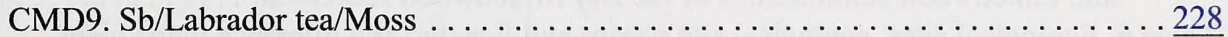

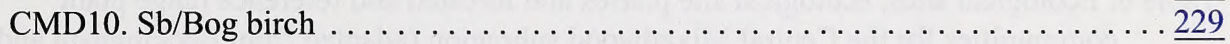

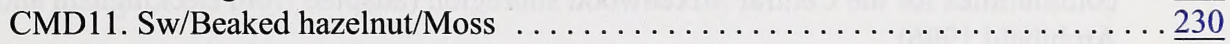

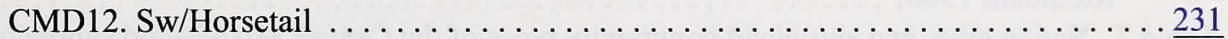

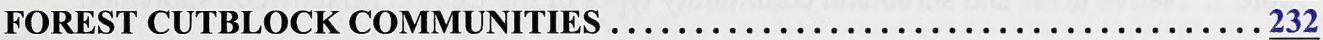

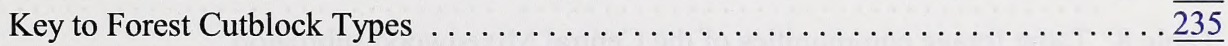

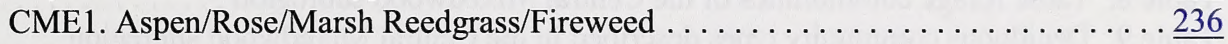

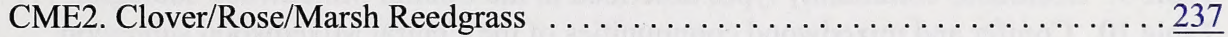

CME3. Beaked Hazelnut/Aspen/Wild Sarsaparilla . . . . . . . . . . . . . . . $\frac{238}{239}$

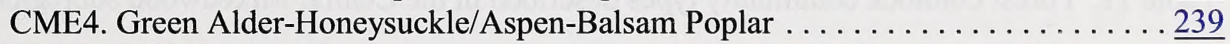

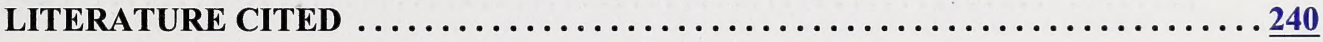

\section{List of Figures}

Figure 1. Ecological Classification System for Alberta $\ldots \ldots \ldots \ldots \ldots \ldots \ldots \ldots \ldots \ldots$

Figure 2. Ecosite phases of the Boreal Mixedwood Natural Region. $\ldots \ldots \ldots \ldots \ldots \ldots \ldots \underline{5}$

Figure 3A. Selected plant species occurrences relative to moisture and nutrient regimes. $\ldots \underline{18}$

Figure 3B. Selected plant species occurrences relative to moisture and nutrient regimes. . . . 19

Figure 4. Edatopic grid for the Dry Mixedwood subregion $\ldots \ldots \ldots \ldots \ldots \ldots \ldots \ldots \ldots \ldots \ldots$

Figure 5. Overview of native grass and shrubland complex in the Dry Mixedwood subregion.

Figure 6. Successional sequences of tame pasture communities on 3 moisture regimes in the Dry

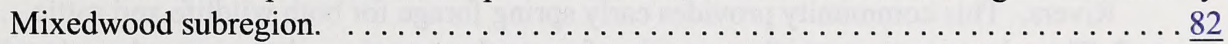

Figure 7. Overview of deciduous communities in the Dry Mixedwood subregion. . . . . 100

Figure 8. Ecology of the native grass and shrublands of the Central Mixedwood subregion. . 154

Figure 9. Successional sequences of tame pasture communities on 3 moisture regimes in the

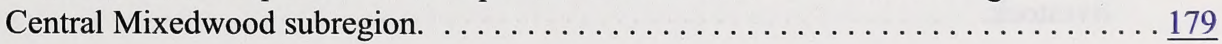


Figure 10. Sequence of Aspen/Rose dominated community types of the Central Mixedwood subregion. . . . . . . . . . . . . . . . . . . . . . . . . . . 191

\section{List of Tables}

Table 1. Ecological sites, ecological site phases, forested, and range plant community types for the Dry Mixedwood subregion (adapted from Beckingham and Archibald 1996) . . . 14

Table 2. Production values and recommended ecologically sustainable stocking rates for grass and shrubland communities, and ecological site phases described in the Dry Mixedwood subregion. .............................

Table 3. Production and Stocking rate of Tame forage communities in the Dry Mixedwood

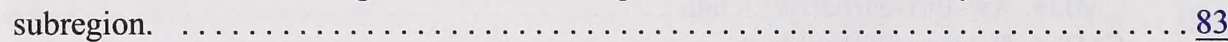

Table 4. Production values and recommended ecologically sustainable stocking rates for the deciduous communities and ecological site phases described in the Dry Mixedwood

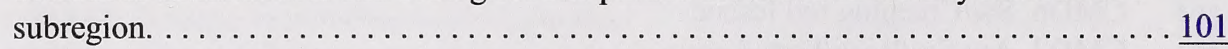

Table 5. Production $(\mathrm{kg} / \mathrm{ha})$ and grazing capacity (ha/AUM) for ecological site phase, conifer and mixedwood communities of the Dry Mixedwood subregion. . . . . . . . 128

Table 6. Ecological sites, ecological site phases and forested and reference range plant communities for the Central Mixedwood subregion (adapted from Beckingham and Archibald 1996) ...........................

Table 7. Native grass and shrubland community types of the Central Mixedwood subregion.

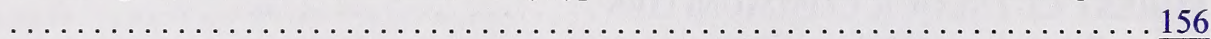

Table 8. Tame forage communities of the Central Mixedwood subregion ..........

Table 9. Deciduous community types described in the Central Mixedwood subregion . . . . $\frac{192}{217}$

Table 10. Conifer and mixedwood communities of the Central Mixedwood subregion .... 217

Table 11. Forest cutblock community types described in the Central Mixedwood subregion $\underline{234}$

\section{List of Maps}

Map 1. Location of Dry and Central Mixedwood Subregions in Alberta. ............. 2

\section{List of Photos}

Photo 1. The Western porcupine grass-Sedge/Fringed sage community is found throughout the Dry Mixedwood subregion on the south-facing slopes of the Smoky, Wapiti and Peace Rivers. This community provides early spring forage for both wildlife and cattle. $\ldots .38$

Photo 2. This picture represents the transition from sedge-marsh reed grass meadows to willow sedge dominated community types in the Dry Mixedwood subregion. These community types provide a large amount of forage, but the moist conditions limit their use by

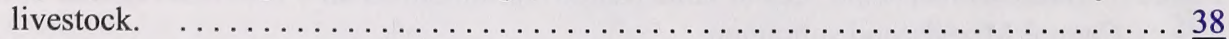


Photo 3. Typical Range improvement clearing in the Dry Mixedwood subregion. . . . . . 80

Photo 4. Aw/Rose/Tall forb community type in the Dry Mixedwood subregion ......... $\underline{98}$

Photo 5. Aw/Hazelnut community is very common in the eastern ecodistricts of the Dry

Mixedwood subregion.

Photo 6. Pj/Bearberry community type in the Dry Mixedwood subregion ..........

Photo 7. This picture represents the Plains wormwood/Sheep fescue-Sedge community type.

This community type is common on dry sandy hills throughout the Central Mixedwood

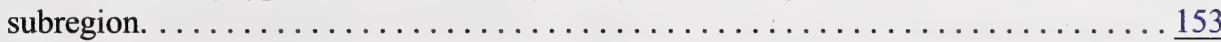

Photo 8. This range improvement clearing exhibits signs of heavy grazing pressure and is slowly being invaded by tall buttercup. ....................

Photo 9. Aw/Rose/Clover community type represents a Central Mixedwood deciduous community that has been moderately to heavily grazed for a number of years. $\ldots \ldots \underline{189}$

Photo 10. The Balsam fir-White spruce/Moss community type is the climatic climax community

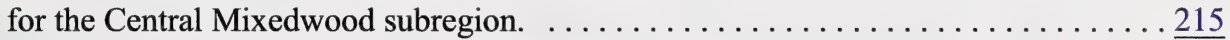

Photo 11. The Aspen/Rose/Marsh Reedgrass/Fireweed (CME1) community type develops after clear-cut logging of the modal Aspen/Rose/Tall Forb (CMC8) community. . . . . 232 


\begin{abstract}
The Dry and Central Mixedwood subregions cover nearly $40 \%$ of the province and are dominated by aspen, jack pine on coarse textured soils and black spruce, willows and sedges in the poorly drained areas. The vegetative communities in these subregions are important because they provide summer range for livestock, prime habitat for many species of wildlife, productive watersheds, recreational areas and timber harvesting. Despite the importance of these vegetation types there is little information on their ecology. The lack of information makes it very difficult to develop sustainable management prescriptions for multiple use. As a result guides like this and "Ecosites of Northern Alberta" (Beckingham and Archibald 1996) are being developed to provide a framework that will easily group the vegetative community types. It is hoped these classification systems can be used by field staff to assess the ecology of the sites and develop management prescriptions on lands within each region.

This guide represents the analysis of 949 grass, shrubland, conifer and deciduous plots described in the Dry and Central Mixedwood subregions. These types are split into:
\end{abstract}

\title{
Dry Mixedwood subregion
}
A. Native grasslands and shrubland
33 types
B. Tame forage communities
13 types
C. Deciduous community types
22 types
D. Mixedwood and Conifer community types
15 types

\section{Central Mixedwood subregion}
A. Native grassland and shrubland
B. Tame forage communities
C. Deciduous community types
D. Mixedwood and Conifer community types
E. Forest Cutblock community types

19 types

7 types

19 types

12 types

4 types 


\section{INTRODUCTION}

The province of Alberta is covered by a broad spectrum of vegetation regions from prairie in the South, to alpine vegetation in the mountains and dense forests in the Central and Northern parts of the province. These broad vegetation regions have been classified into 6 regions and 20 subregions (Dept. of Environmental Protection 1994). Within each subregion, there are groups of plant communities which exist under similar, localized, environmental conditions and can be further influenced by human impacts. Sustainable management of these subregions requires an understanding of the ecology of the site as well as the ability to recognize the vegetative communities that have similar productivity and response to disturbance.

Vegetative communities in the province of Alberta are highly regarded by most resource managers for their ability to provide a wide variety of benefits. They are a classic example of multiple use land, providing summer range for livestock, prime habitat for many species of wildlife, productive watersheds and recreational areas. Despite the importance of these vegetation types there is little information on their ecology. The lack of information makes it very difficult to development sustainable management prescriptions for multiple use.

The purpose of this guide was to develop a framework that would easily group the plant community types utilized by livestock in the Dry and Central Mixedwood subregions of the province and provide ecologically sustainable stocking rate information. Plant communities are grouped into a hierarchal system based on ecology. These groupings include successional communities which occur under natural succession or disturbance such as fire, timber or grazing operations. All of the known relationships among communities are described within this guide in table format and/or schematically. Additionally, each known plant community is described in detail.

It is hoped this classification system can be used by field staff to assess the ecology and sustainable stocking rate of sites in order to develop management prescriptions on lands within each subregion. This guide supplements the work done by Beckingham and Archibald (1996) on the forested community types in the Boreal Mixedwood of northern Alberta. Their guide is a good description of the forested community types found within the subregions, but it does not include forage production values or grazing management information. It also does not provide a description of the native grassland and shrubland communities which are utilized extensively by livestock in these subregions.

\section{CLIMATE AND MODAL PLANT COMMUNITIES}

\section{Dry Mixedwood subregion}

The Dry Mixedwood (DM) subregion represents a transition between the Central and Peace River Parklands and the Central Mixedwood subregions. This subregion occurs in three areas of the province (Map 1). One section is located between the Central Parkland and the Central Mixedwood subregions in the southern portion of the boreal forest and includes the Onion Lake, Athabasca, Westlock plains and Whitefish and Frog Uplands ecodistricts (Strong 
and Thompson 1995). A second area is located immediately east of Edmonton in the Cooking Lake upland ecodistrict. The third and largest area parallels the Peace River in northwestern Alberta from Grande Prairie to Fort Vermillion and includes the Debolt, Dunvegan, Falher, Smoky, Grimshaw, Manning, High Level and Boyer plains ecodistricts.

Mean summer temperature is $13.8^{\circ} \mathrm{C}$ and winter temperatures average $-10.5^{\circ} \mathrm{C}$, which is somewhat warmer than the Central Mixedwood subregion and somewhat cooler than the Parkland subregion. Mean annual precipitation is $380 \mathrm{~mm}$, which is drier than the Central Mixedwood, but wetter than the Parkland subregion.

The modal plant community in this subregion is dominated by aspen, with a variable understory dominated by rose, pea-vine, beaked hazelnut, saskatoon and marsh reed grass. Jack pine stands are found on well drained, coarse-textured parent materials and poorly drained sites are dominated by black spruce, willows and sedge species.

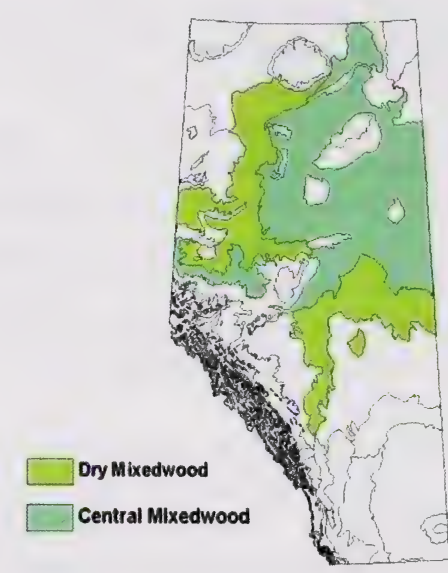

Map 1. Location of Dry and Central Mixedwood Subregions in Alberta.

\section{Central Mixedwood subregion}

The Central Mixedwood (CM) subregion is the largest in the province covering over $210,000 \mathrm{~km}^{2}$ or nearly $32 \%$ of the province (Strong and Leggat 1992)( Map 1). Mean annual summer temperature is $13.5^{\circ} \mathrm{C}$ and winter temperature averages $-13{ }^{\circ} \mathrm{C}$. Annual precipitation averages $397 \mathrm{~mm}$ which is wetter than the Dry Mixedwood.

The modal plant communities are vegetated by aspen and balsam poplar with understories composed of a variety of herbs and deciduous shrubs. White spruce and balsam fir are the climatic climax species but are not well represented because of the frequent occurrence of fire. On dry, well drained, coarse-textured soils jack pine dominates and the poorly drained sites are dominated by black spruce, willows and sedge species. These communities are very similar to the Dry Mixedwood subregion, but drier conditions of the Dry Mixedwood favours formation of a number of native grassland communities which are not found in the Central Mixedwood. 


\section{APPROACH AND METHODS OF CLASSIFICATION}

\section{Approach: Ecological classification hierarchy and terminology}

The system of classification in this guide was initially based on the community type approach of Mueggler (1988). Mueggler's system was chosen over the habitat type approach (Daubenmire 1952) or ecosystem association approach (Corns and Annas 1986) because it could classify plant communities irregardless of their successional status. However, as the philosophy of rangeland health and proper functioning condition of a site evolved, it became apparent (through data analysis) that there was a need to also organize the various plant communities based on their response to disturbance (i.e. disturbance vs. natural succession) within an area under similar environmental influences.

It was determined that the ecosystem classification system developed by Corns and Annas (1986) and Beckingham et al. (1996) could accommodate this additional requirement. Thus, the new system developed for rangelands is a combination of Mueggler (1988) and Beckingham et al. (1996). Consequently, this guide adopts a similar ecological unit classification hierarchy (ecosite, ecosite phase, plant community). In an effort to first, link the hierarchical system with the historic rangeland system, and second, to create a provincially standardized rangeland approach, slightly different classification terminology was developed. The new terms ecological site and ecological site phase (replacing Beckingham et al.'s [1996] ecosite and ecosite phase terms respectively), provide subtle distinction to recognize the blending of the old systems and still be recognizable to readers familiar with the original terminology. See Figure 1 for a flow chart of the classification and general presentation of information. See Figure 2 for a representation of the ecosite phases in the Boreal Mixedwood Region.

\section{Methods: Plant community classification}

Sampling for this guide occurred within the Dry and Central Mixedwood subregions. This guide outlines the classification of 685 plots described in the Dry Mixedwood and 210 plots described in the Central Mixedwood subregions. The procedure for inventory of plots followed the Range Survey Manual (1992) and uses the MF5 form. A plot consisted of a $10 \mathrm{~m} \mathrm{x} 10 \mathrm{~m}$ macroplot and ten randomly selected $1 \mathrm{~m} \times 1 \mathrm{~m}$ microplots to record the canopy cover of shrubs and ten nested $20 \mathrm{~cm} \times 50 \mathrm{~cm}$ microplots to record the canopy cover of forbs and grass. For a description of the methodology for riparian plots done in the Mixedwood subregions see (Thompson and Hansen 2004). The data for each site was analysed using the multivariate analysis techniques of classification and ordination. Classification is the assignment of samples to classes or groups based on the similarity of species. A polythetic agglomerative approach was used to group the samples. This technique assigns each sample to a cluster which has a single measure. It then agglomerates these clusters into a hierarchy of larger and larger clusters until finally a single cluster contains all the samples (Gauch 1982). Cluster analysis was performed in SAS and Euclidean distance was used as the Cluster Distance Measure and Ward's method was used in the Group Linkage Method. The groupings generated in cluster analysis were overlain on the site ordination to determine final groupings. 


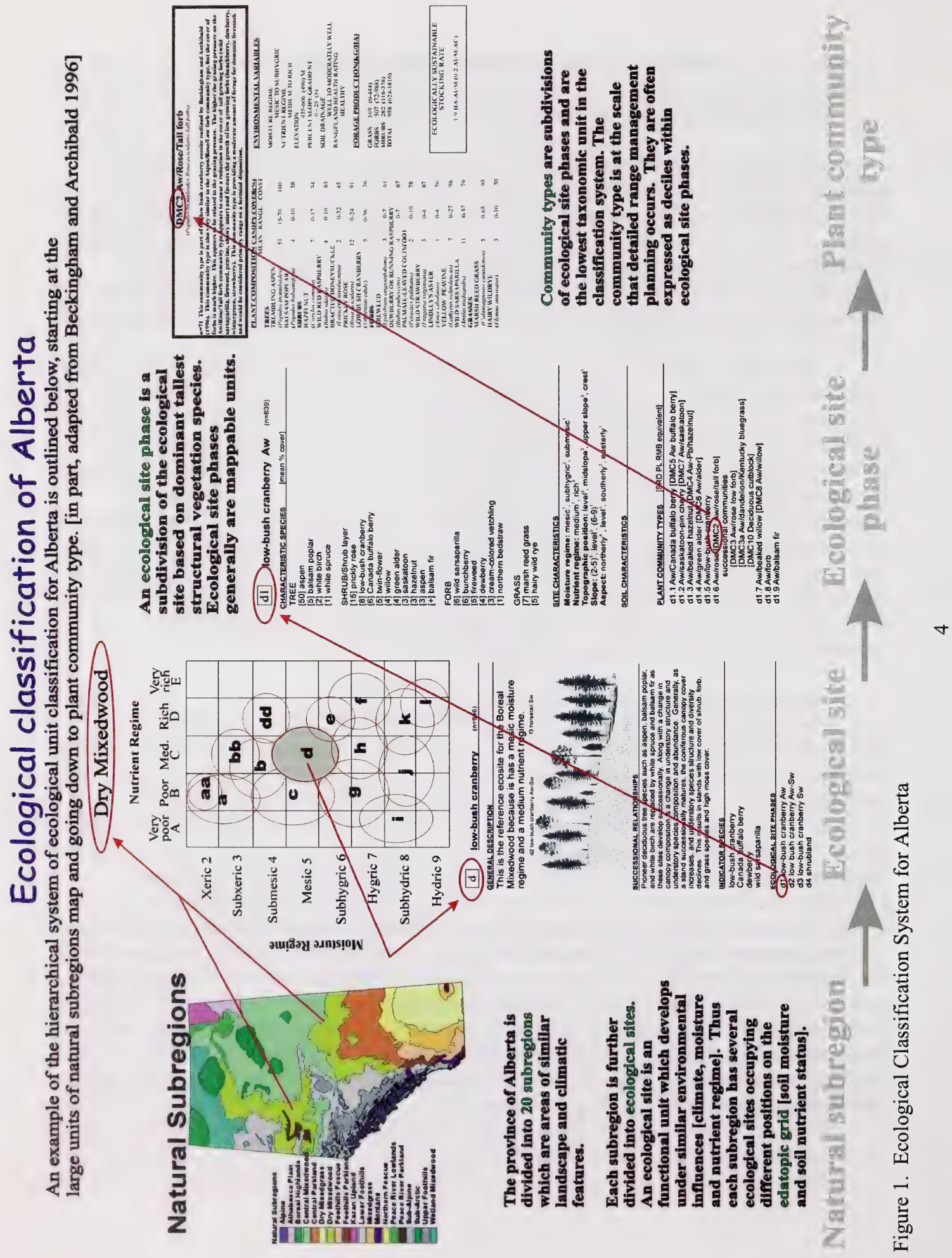



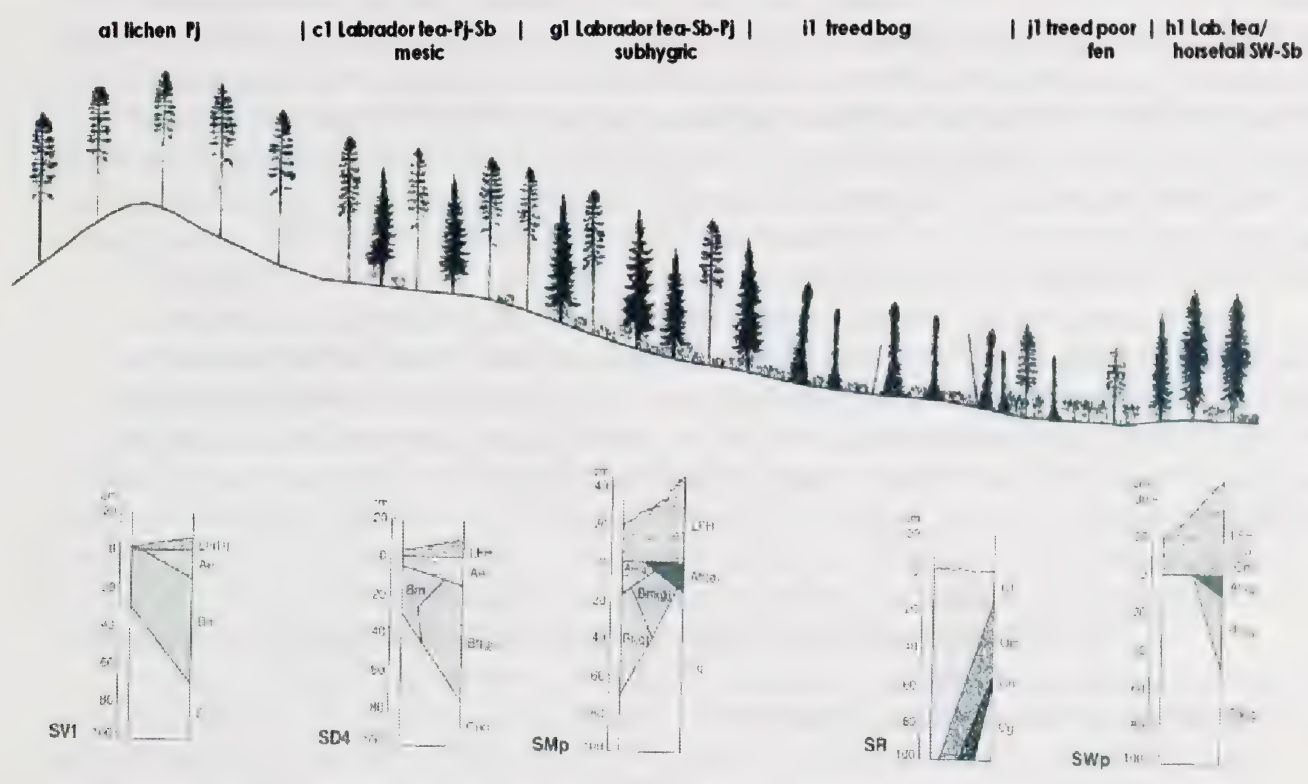

b1 bluebery Pj-Aw | d2 lowbush cranberry Aw-Sw | el dogwood Pb-Aw | B horsetail Sw | k2 shrubby rich fern | II marsh

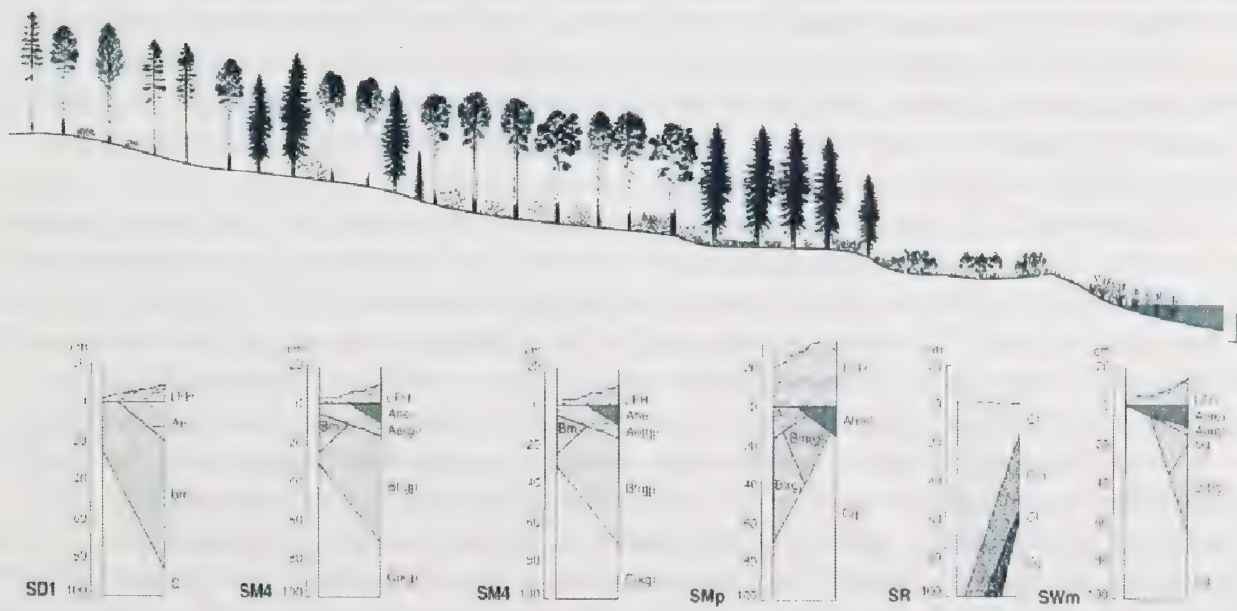

Source: Figure 12 Schematic cross section of the Boreal Mixedwood represented by common ecosite phases and soil types. (Beckingham and Archibald 1996)

Figure 2. Ecosite phases of the Boreal Mixedwood Natural Region. 
Ordination was used to find relationships among species, communities and environmental variables. Ordination reduces the dimensionality of the data to 1-3 most important axes to which environmental gradients can be assigned. The ordination technique used in the analysis of the data was DECORANA (Detrended Correspondence Analysis). DECORANA detrends and rescales the axes thereby reducing the arching and compression of axes problems associated with other ordination techniques (Reciprocal averaging, Principle Components Analysis). Once final groupings were determined on the ordination specific environmental variables can be assigned to the variation outlined on the ordination axes.

Plant community type summaries were generated in SAS, by averaging plant species composition, range in composition, and percent constancy of occurrence, among vegetation inventory plots which were part of a community type. Environmental data was subsequently sorted into the same plant community groupings to create the plant community descriptions outlined in this guide. The number of sample plots on which the description was based is also provided (e.g. $n=16)$.

\section{RANGE MANAGEMENT CONCEPTS AND METHODS}

\section{Ecologically sustainable stocking rates}

Ecologically sustainable stocking rates (ESSR) values are suggested for each plant community. These values reflect the maximum number of livestock (i.e animal unit month [AUM] per area [e.g. ac]) that can be supported by the plant community given inherent biophysical constraints and the ecological goal of sustainable health and proper functioning of the plant community. When the ESSR is multiplied by the area of a plant community polygon the result is termed ecologically sustainable carrying capacity (ESCC), and is expressed as AUMs. Often the ESCC must be adjusted for management factors (e.g. reduced livestock distribution), management goals (e.g. multiple use and values, etc.), drought conditions, and other natural phenomena impacting the site (e.g. forage quality, fire, pests, etc.). This adjusted/reduced value is the ecologically sustainable grazing capacity (ESGC). The ESGC values are not provided in the plant community guide because the necessary adjustments are determined by the rangeland resource manager.

Suggested ESSR values were determined from a combination of clipping studies, longterm rangeland reference area data, estimated production, and historical grazing experience. In order to sustain ecological health and function of the plant community, the ESSR was based on the allocation of up to $25 \%$ of total production for forested plant community types, and up to 50 $\%$ of total production for grass and shrub land types within the Dry and Central Mixedwood subregions, and the forage requirements one animal unit (i.e. $455 \mathrm{~kg}$ of dry matter per month). The stocking rate ranges provided, are based on total forage production tempered by the forage value of the contributing plant species and the ecological status of the plant community. For example a plant community with high total production but that is mostly composed of unpalatable or unreachable material will have a high end range value based on less than $25 \%$ of total production. If this same plant community is of low ecological status, a further reduction is made to the range and the recommended stocking rate to allow for health recovery. The unallocated biomass production (carry over), is needed for the maintenance of ecological 
functions (e.g. nutrient cycling, viable diverse plant communities, hydrological function, and soil protection, etc.) and plant community services (forage production, habitat maintenance, etc.). The allocation of biomass production in this manner is well established, and supported, by the scientific community and the percent allocation varies with Natural Subregion (Holechek et al. 1995).

\section{Rangeland Health}

Range health is determined by comparing the functioning of ecological processes on an area (e.g. plant community polygon) of rangeland to a standard (i.e. RPC) described within an ecological site description. An ecological site is similar to the concept of range site, but a broader list of characteristics are described. An ecological site is defined by the Task Group on Unity and Concepts (1995) as, "a distinctive kind of land with specific physical characteristics that differs from other kinds of land in its ability to produce a distinctive kind and amount of vegetation". This guide can be used to determine the appropriate reference range plant community, within an ecological site, for a rangeland health assessment.

Rangeland health assessments are utilized to make a rapid determination of the ecological health of rangeland. We use range health terminology (healthy, healthy with problems, or unhealthy), to rank the ability of rangeland to perform certain ecological functions. These functions include: net primary production, maintenance of soil/site stability, capture and beneficial release of water, nutrient and energy cycling and plant species functional diversity. For a detailed description on how to assess rangeland health for various plant communities please refer to "Rangeland Health Assessment for Grassland, Forest and Tame Pasture" (Adams et al. 2003).

A ecological status score [i.e. the integrity of the plant community composition compared to the reference plant community] has been added to each community type description. These values are based on what is currently known about how a reference plant community (RPC) responds to various kinds and levels of disturbance or successional processes. The values indicate how a particular plant community fits in the state and transition model relative to the RPC. If an experienced observer wishes to estimate the health of a plant community without competing a health form, (e.g. a small riparian area), these values can be used as a guide. Occasionally there are 2 options provided for the ecological status score. This was done for two reasons: 1) to express the range of divergence from the RPC possible for a particular plant community; or 2) to allow for different health forms to be used in communities with variable shrub or tree cover (e.g. on sites with high woody cover and/or an obvious LFH layer use the forest rangeland health form and the corresponding ecological status score; on sites dominated by herbaceous cover and/or an obvious herbaceous litter layer use the native grassland form). [Note: For riparian plant communities the riparian health assessment form should be used.]

Range management objectives tend to favour the later stages of plant succession (lateseral to potential natural community (PNC) or good to excellent range condition) (Adams et al. 2003). Late seral plant communities tend to be superior in the efficient capture of solar energy, in cycling of organic matter and nutrients, in retaining moisture, in supporting wildlife habitat values and in providing the highest potential productivity for the site. In contrast, early seral stages represent plant communities with diminished ecological processes, which are less stable 
and more vulnerable to erosion and invasion by weeds and non-native species. They also have diminished resource values for livestock forage production, wildlife habitat and watershed protection (Adams et al. 2003). Healthy rangelands perform important ecological functions and provide a broader suite of goods and services. In most cases these late seral plant communities are used as the RPC, but sometimes management goals influence the choice of RPC (e.g. a cut block to be maintained as untimbered rangeland).

\section{HOW TO USE THE GUIDE}

\section{Organization of the guide}

This guide is an expansion of the Ecosites of Northern Alberta guide (Beckingham and Archibald 1996). It contains new information and it is recommended that the reader has access to relevant information from both guides. The community types in this guide are closely related to the ecosites and ecosite phases outlined in Ecosites of Northern Alberta (Beckingham and Archibald 1996), and are similarly arranged (e.g. Table 1). Table 1 and Table 6 are a reproduction of Figure 11 in Ecosites of Northern Alberta with community types in this guide further separated into reference range plant communities, successional communities and harvesting and fire communities. The "Successional community types" or "Harvesting and Fire succession" categories outline the successional sequence the community types undergo with heavy grazing pressure, harvesting or fire disturbance.

The majority of ecological site and ecological site phase summary tables as well as the plant community descriptions are recorded in Ecosites of Northern Alberta (Beckingham and Archibald 1996). Any new ecological sites and ecological site phases reported in the fourth approximation are also included in this guide and are summarized before the community type descriptions. The bulk of this guide is community descriptions which include information on the dominant plant species, canopy cover, environmental conditions, response to grazing, forage production and suggested ESSRs. When available, we have included plant community successional information to help us determine rangeland health and the successional relationships on an ecological site.

Generally, in both guides, ecological units within a subregion are classified by their position on the edatopic grid [a specific combination of soil moisture and soil nutrient regime] (Figures 3 and 6).

The information in this guide is presented and named by:

1. Subregion/Ecological area
a. Dry Mixedwood [DM]
b. Central Mixedwood [CM]

2. Dominant cover type
a. Native grasslands and Shrublands [A]
b. Tame forage communities [B]
c. Deciduous forest [C]
d. Mixedwood and Conifer forest [D]
e. Forest Cutblock communities [E] 
NOTE: Each dominant cover type may overlay several ecological sites and ecological site phases. For example DMA community types occur in 8 ecological sites [aa, bb, c, d, dd, f, k, and 1].

3. Community types are presented and named by:

a. Subregion/Ecological area and dominant cover type [e.g. DMA].

b. Position on the edatopic grid. Generally, communities are named/numbered from low moisture /nutrient status to high moisture/nutrient status. For example, DMA3 is a Plains wormwood/Sedge community on the"aa" xeric/poor ecological site, while DMA7 is a Saskatoon-snowberry/hairy wild rye community type on the "d" mesic medium ecological site.

NOTE: As additional information is collected and new ecological units are identified and described, an attempt is made to fit them into the pre-existing ones. At times the usual conventions of naming and organization have to be compromised to accommodate the new units. Sometimes it was necessary to add an additional letter to an existing name to wedge the new unit into the appropriate place within the pre-existing ones. For example, the extra letter in the new ecological site "dd" and the pre-existing ecological site "d".

\section{Identifying plant community types}

There are two methods to identify plant community types in this guide. The first method uses a key within the dominant cover categories of native grass and shrubland, tame forage, deciduous, or mixedwood and conifer. The second method involves using soil moisture and nutrient information and indicator species to identify plant community types.

\section{Method 1. Use dichotomous key within dominant cover categories}

Step 1. Pick the appropriate subregion [DRY MIXEDWOOD or CENTRAL MIXEDWOOD].

Step 2. Pick the appropriate category the community type is in within each subregion.

A. The area does not have an overstory tree canopy and has not been cleared and broken, the community will fall under the NATIVE GRASSLANDS and SHRUBLANDS category.

B. The area has been cleared of trees, broken, and seeded down to tame forage species such as timothy or creeping red fescue, the community will be in the TAME GRASS category.

C. The DECIDUOUS category includes all plant communities that are dominated, [i.e. $\geq 70 \%$ of the overstory], by deciduous tree species. Deciduous cutblocks are included here.

D. Communities which have begun to undergo succession from deciduous to conifer overstory may fall into the MIXEDWOOD category. The following is a general rule of thumb. The site is a mixedwood community if the conifer and the deciduous overstories each range between $30-70 \%$ of the total overstory cover. For example a deciduous cover of $40 \%$ and a conifer cover of $60 \%$ is a mixedwood community. If in doubt, determine if the 
understory is responding more to a deciduous or coniferous influence [e.g. loss of production due to conifer shading]. Communities dominated [i.e. $\geq 70 \%$ of the overstory] by a conifers are classified in the CONIFER category.

Step 3. Turn to the appropriate section [e.g. DMA] and work through the key provided to determine the choose the closest matching community type for the site you are evaluating. At times, the community in question does not seem to match any of the known / reported types. When this happens, consider the following information in the detailed community type descriptions.

1. In the general description text.

a. The number of plots utilized to describe the community [ $\mathrm{n}=$ number of plots]. The greater the number of plots [i.e. information available], the greater the level of confidence in the clarity and accuracy of the description including the suggested ESSR.

b. Information about where the community is found on the landscape, response to disturbance, and natural succession. Use this information together with your field experience to determine the likely hood of a similar situation occurring on the site in question.

2. Under Plant Composition heading.

a. The range of a plant species canopy cover. For example, a species with a range of $0-25 \%$ may not always be visible on the site, having $0 \%$ canopy cover or it may have up to $25 \%$ cover.

b. The consistency value. This indicates the percentage of the plots that the species was actually present. So if $\mathrm{n}=16$ and consistency was $75 \%$, then the species occurred in 12 of the plots and not in 4 of them.

c. Note that tree species in the shrub LAYER are listed in the shrub section.

3. Try to use the other method to see if you can determine the plant community.

Step 4. This step is necessary only if you are completing a rangeland health assessment. In order to determine the health status of the site in question, you must decide the appropriate reference range plant community $[\mathrm{RPC}]$ to compare it to. Depending on the type of disturbance [grazing, timber operations, etc.] successional pathways may differ. The RPC would usually be the plant community that is at the start of the pathway. Management goals can influence the choice of RPC. For example, if an aspen-rose community on a "d" ecological site [e.g. DMC2] had undergone timber harvest, had not been seeded with tame forage species and the goal was to maintain it as a native community with out a mature aspen canopy, the appropriate RPC would be DMC10. Alternatively, if the site was to be cultivated, seeded and managed as a tame pasture, the appropriate RPC might be DMB12. 
Method 2. Use edatope and indicator species [see appendix for indicator species list and page 18-19 for plant edatopes.]

Step 1. Pick the appropriate subregion [DRY MIXEDWOOD or CENTRAL MIXEDWOOD]. [e.g. DM]

Step 2. Determine the appropriate ecological site based on position on the edatopic grid for the subregion. First decide soil moisture status, then soil nutrient status of the site in question. Use any available soils information to assist [e.g. AGRASID, or PLC]. [e.g. DM - mesic/medium is the "d" low-bush cranberry ecological site or DM-d]

Step 3. Look up the possible ecological site phases within the selected ecological site on Table 1 or 6. [e.g. DM-d has "d1" low-bush cranberry aspen; "d2" low-bush cranberry aspen spruce; "d 3 "low-bush cranberry white spruce; and " $\mathrm{d} 4$ " shrubland.]

Step 4. Select the appropriate ecological site phase by first determining the dominant overstory [i.e the highest layer of vegetation which can be either a tree, shrub, or grass species]. [e.g. For a site dominated by aspen (i.e. DM-d1), the appropriate ecological site phase is "dl" low-bush cranberry aspen.]

Step 5. Select the appropriate community type. Within the selected ecological site phase, use indicator understory species to choose the closest matching community type. This information is shown in table 1 or 6 as part of the community type name [e.g. DMC7 aspen/saskatoon]. It is also detailed in the specific community type descriptions [i.e. species with the highest average canopy cover and consistency]. At times, the community in question does not seem to match any of the known / reported types. When this happens, consider the following information in the detailed community type descriptions.

1. In the general description text.

a. The number of plots utilized to describe the community [ $\mathrm{n}=$ number of plots]. The greater the number of plots [i.e. information available], the greater the level of confidence in the clarity and accuracy of the description including the suggested ESSR.

b. Information about where the community is found on the landscape, response to disturbance, and natural succession. Use this information together with your field experience to determine the likely hood of a similar situation occurring on the site in question.

2. Under Plant Composition heading.

a. The range of a plant species canopy cover. For example, a species with a range of $0-25 \%$ may not always be visible on the site, having $0 \%$ canopy cover or it may have up to $25 \%$ cover.

b. The consistency value. This indicates the percentage of the plots that the species was actually present. So if $n=16$ and consistency was $75 \%$, then the species occurred in 12 of the plots and not in 4 of them.

c. Note that tree species in the shrub LAYER are listed in the shrub section. 
3. Try to use the other method to see if you can determine the plant community.

Step 6. This step is the same as step 4 in method 1 and is necessary only if you are completing a rangeland health assessment. In order to determine the health status of the site in question, you must decide the appropriate reference range plant community [RPC] to compare it to. Depending on the type of disturbance [grazing, timber operations, etc.] successional pathways may differ. The RPC would usually be the plant community that is at the start of the pathway. Management goals can influence the choice of RPC. For example, if an aspenrose community on a "d" ecological site [e.g. DMC2] had undergone timber harvest, had not been seeded with tame forage species and the goal was to maintain it as a native community with out a mature aspen canopy, the appropriate RPC would be DMC10. Alternatively, if the site was to be cultivated, seeded and managed as a tame pasture, the appropriate RPC might be DMB12. 
DRY MIXEDWOOD SUBREGION

13 


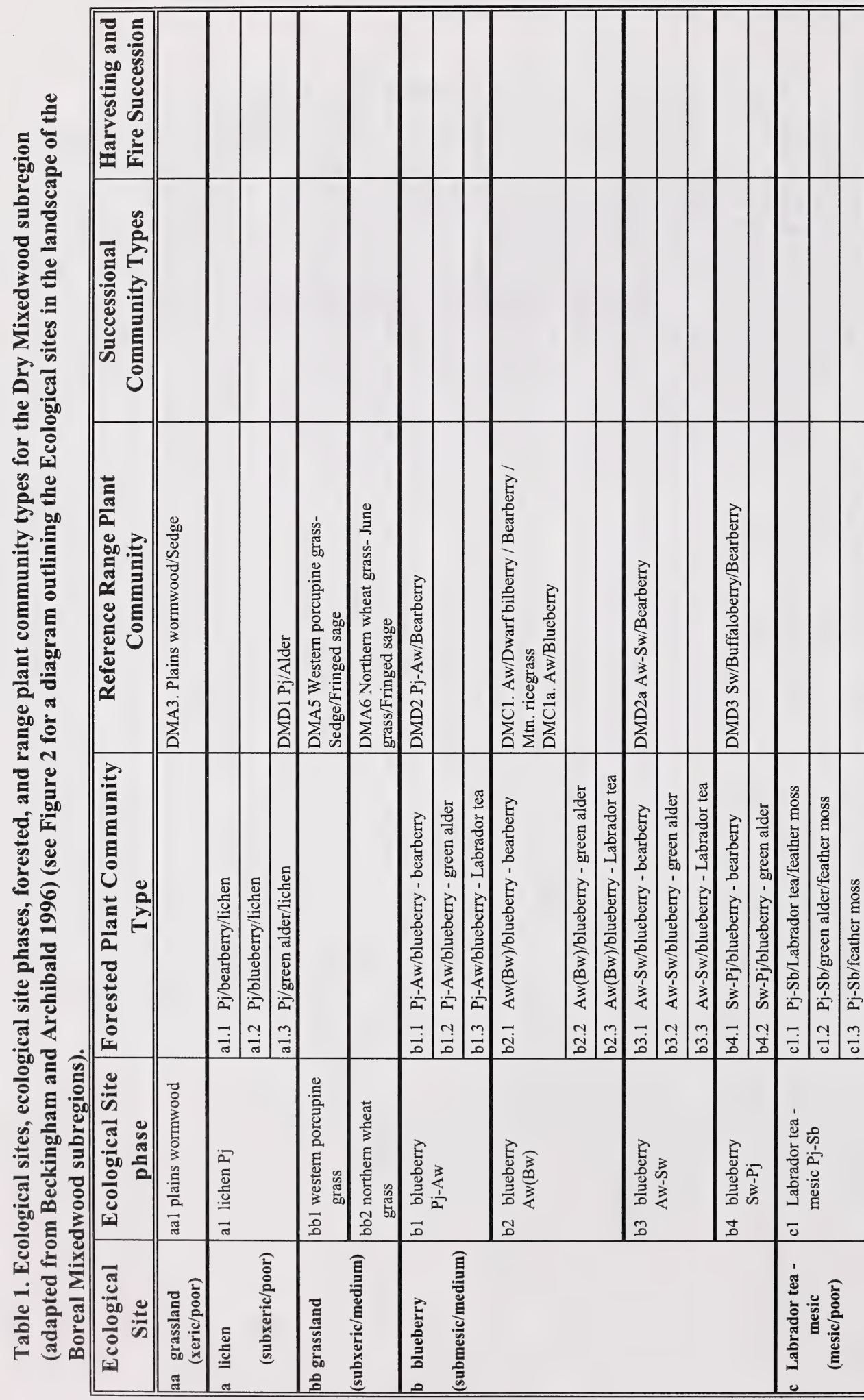




\begin{tabular}{|c|c|c|c|c|c|c|c|c|c|c|c|c|c|c|c|c|c|c|c|c|c|c|c|}
\hline 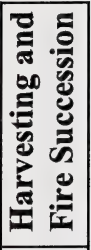 & & & & & & 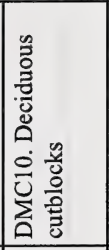 & & & & & & & & & & & & & & & & 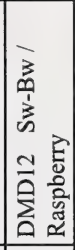 & \\
\hline 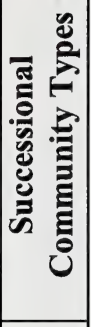 & & & & & & 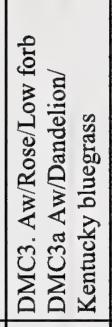 & & & & & & & & & & & & & & & & & 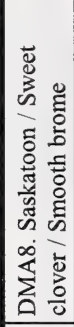 \\
\hline 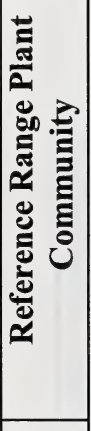 & 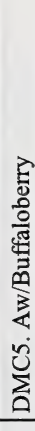 & 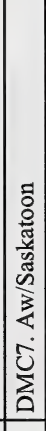 & 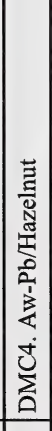 & 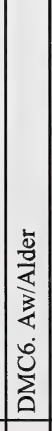 & & 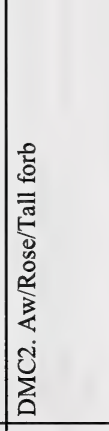 & 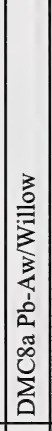 & & & & & & 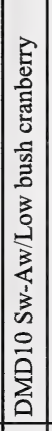 & 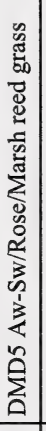 & & & & & 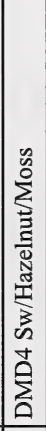 & 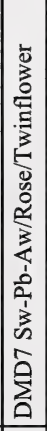 & & 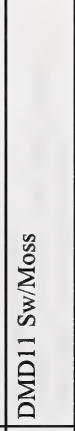 & 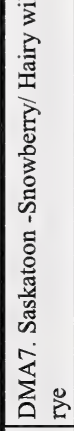 \\
\hline 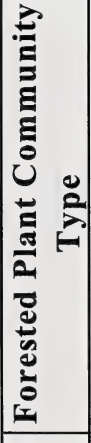 & 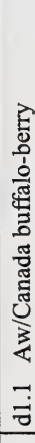 & 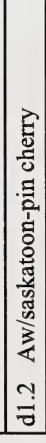 & 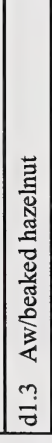 & 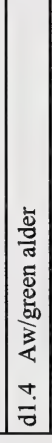 & 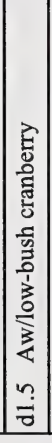 & 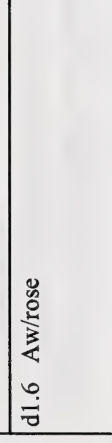 & 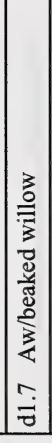 & 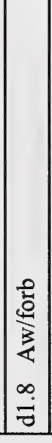 & 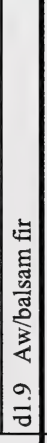 & 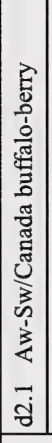 & 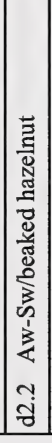 & 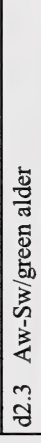 & 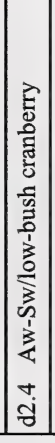 & 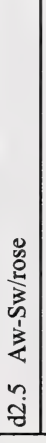 & 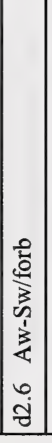 & 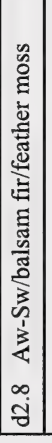 & 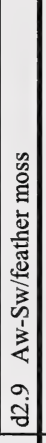 & 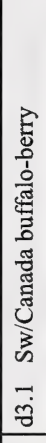 & 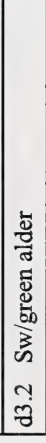 & 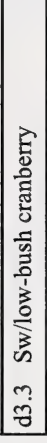 & 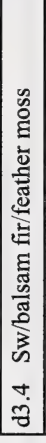 & 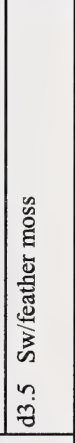 & \\
\hline 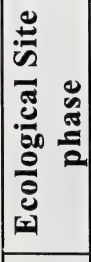 & & 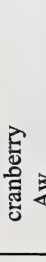 & & & & & & & & & 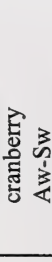 & & & & & & & & $\sqrt{3}$ & & & & 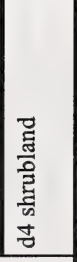 \\
\hline 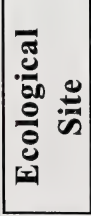 & & 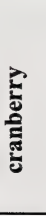 & 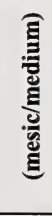 & & & & & & & & & & & & & & & & & & & & \\
\hline
\end{tabular}




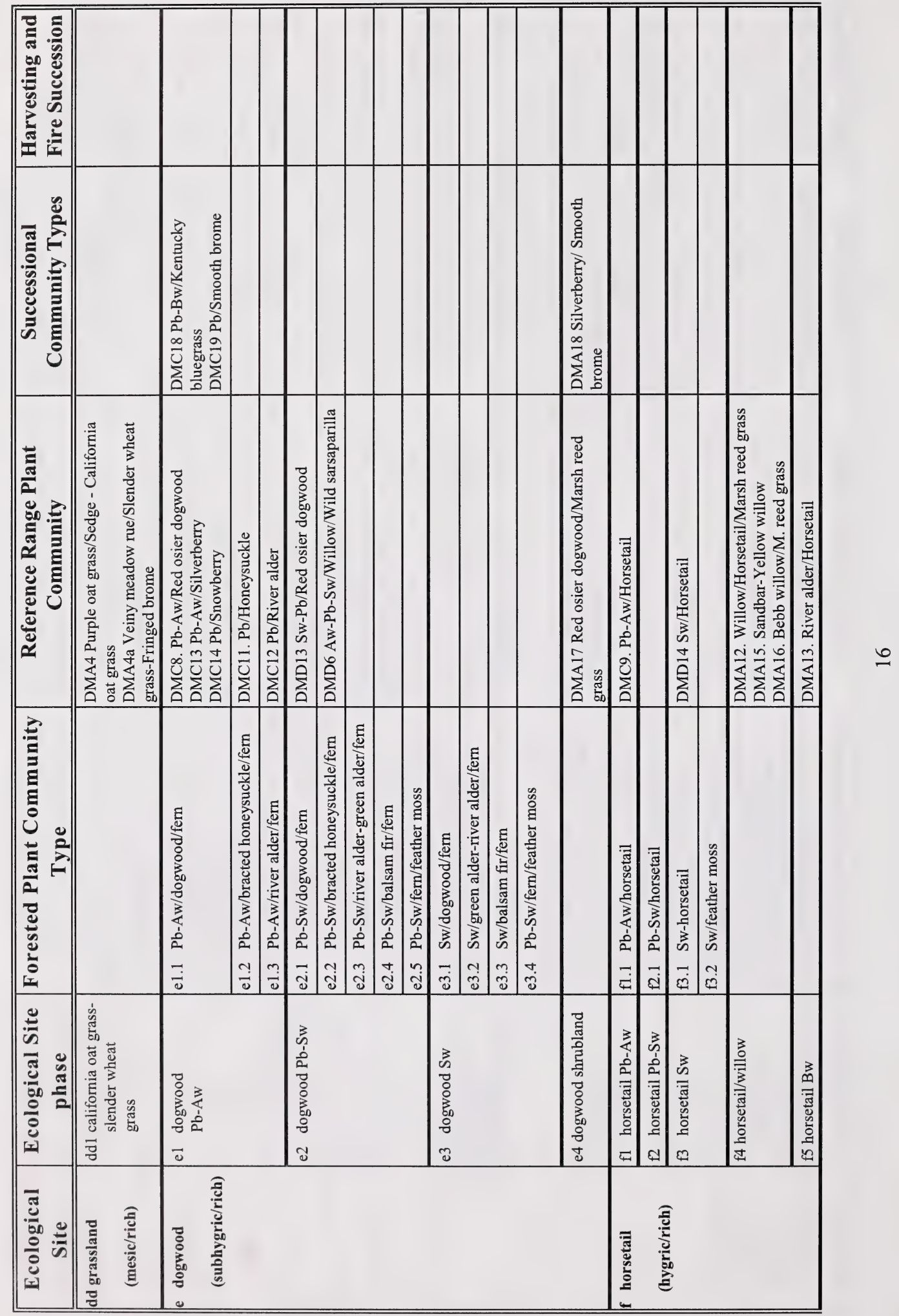




\begin{tabular}{|c|c|c|c|c|c|c|c|c|c|c|c|c|c|c|c|c|}
\hline 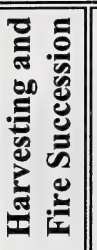 & & & & & & & 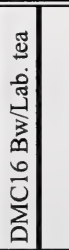 & & 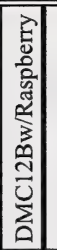 & & & & & & & \\
\hline 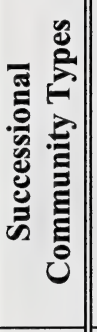 & & 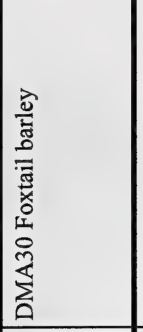 & & & & & & & & & 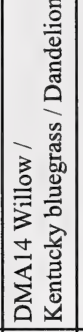 & 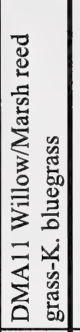 & $\begin{array}{l}8 \\
y \\
5 \\
0 \\
0 \\
0 \\
0 \\
0\end{array}$ & & & \\
\hline 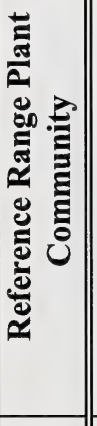 & & 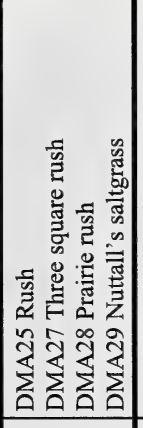 & & & 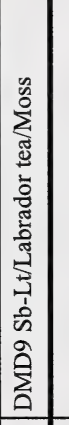 & & 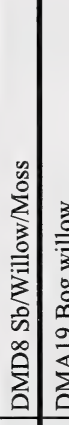 & 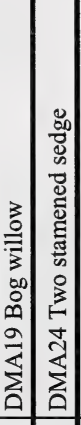 & 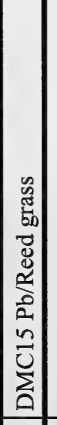 & & 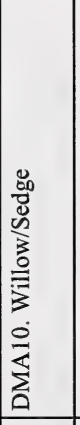 & 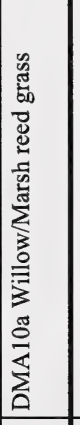 & 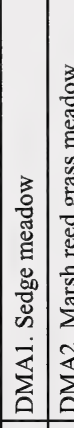 & 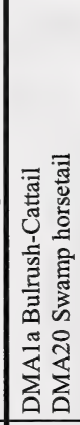 & 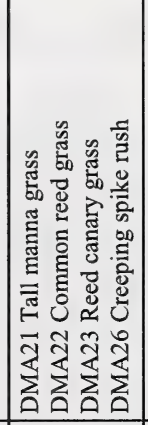 & \\
\hline 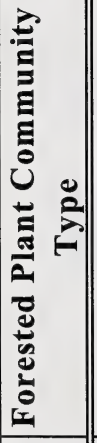 & 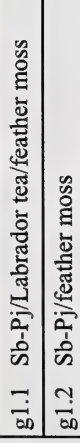 & & 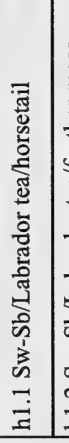 & 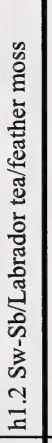 & 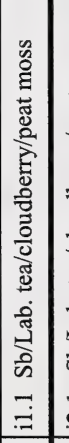 & 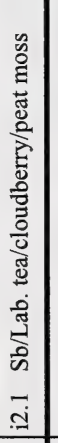 & 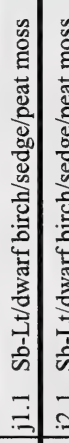 & 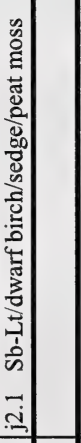 & 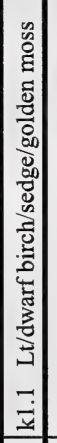 & 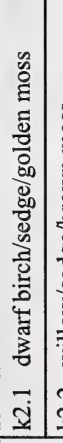 & 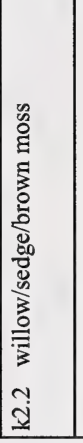 & 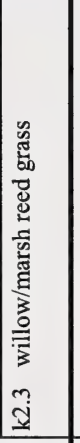 & 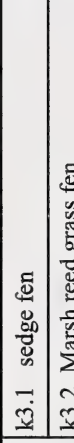 & 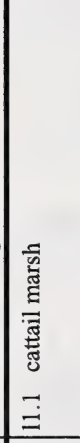 & 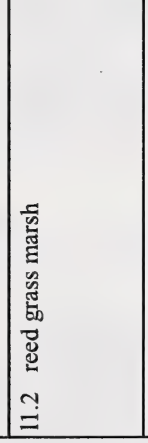 & $\exists$ \\
\hline 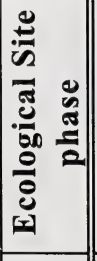 & 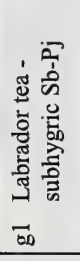 & 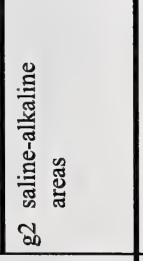 & 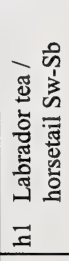 & & \begin{tabular}{c|}
0 \\
0 \\
0 \\
0 \\
0 \\
$\Xi$ \\
$\Xi$ \\
$=$ \\
$=$
\end{tabular} & 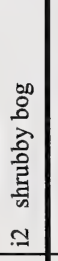 & 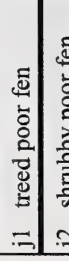 & 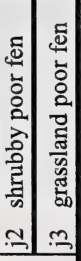 & 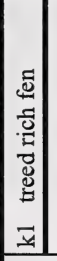 & 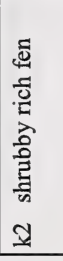 & & & 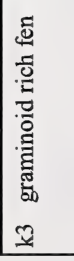 & 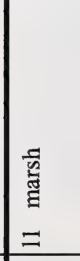 & & \\
\hline 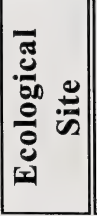 & 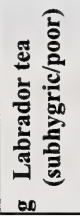 & & 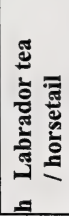 & : & 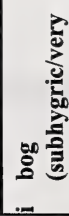 & : & 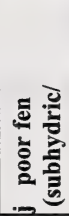 & है & 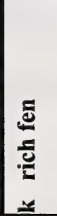 & 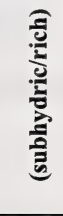 & & & & 해 & 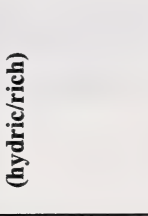 & \\
\hline
\end{tabular}



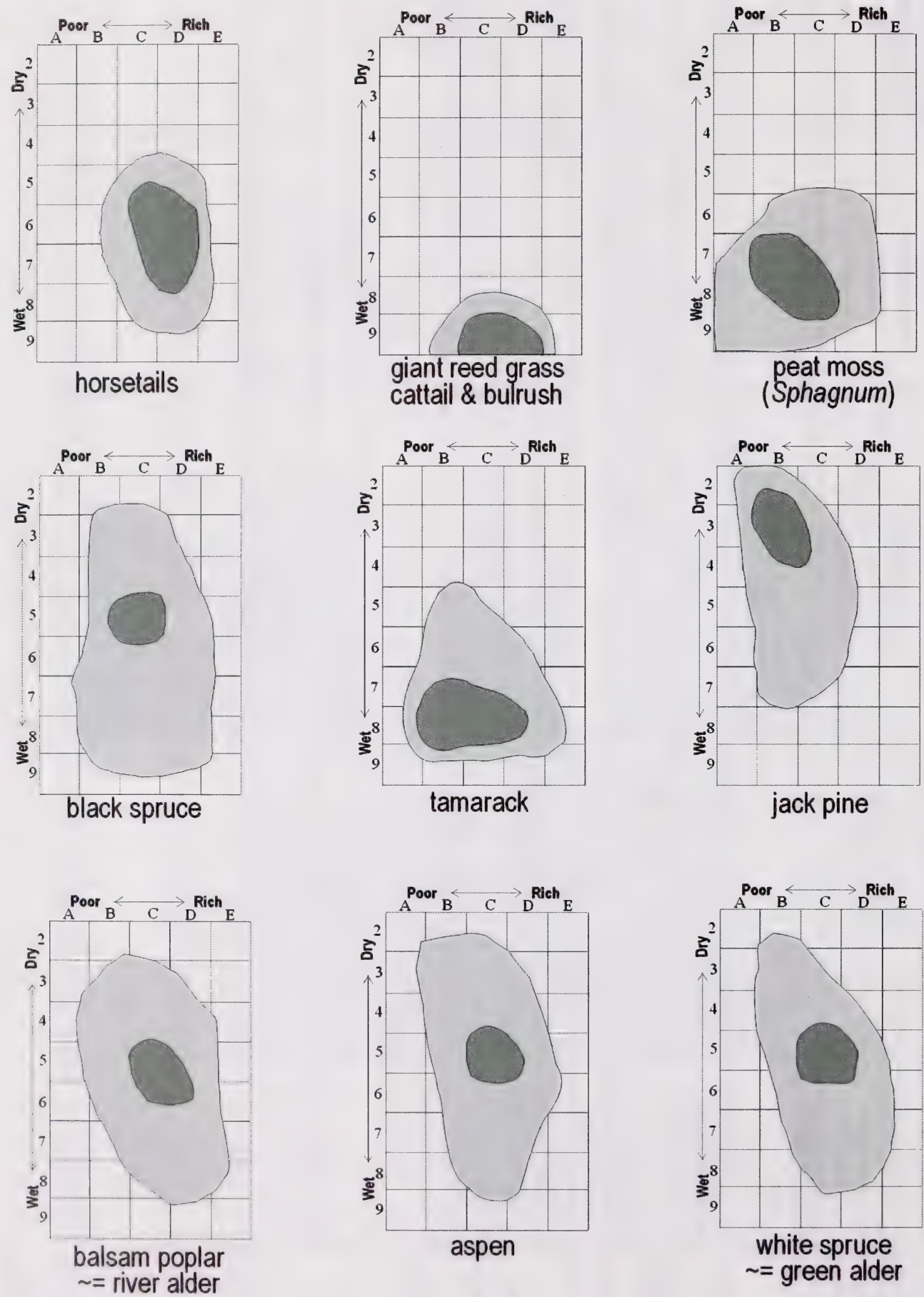

Figure $3 \mathrm{~A}$. Selected plant species occurrences relative to moisture and nutrient regimes. 


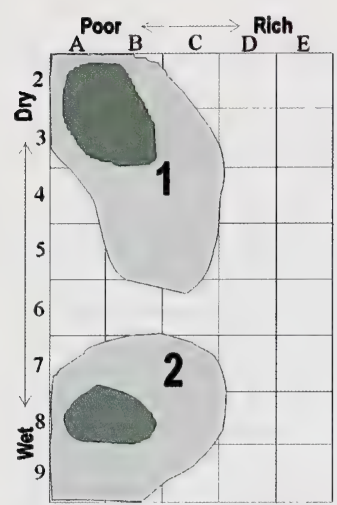

1 - reindeer lichen

2- cloudberry
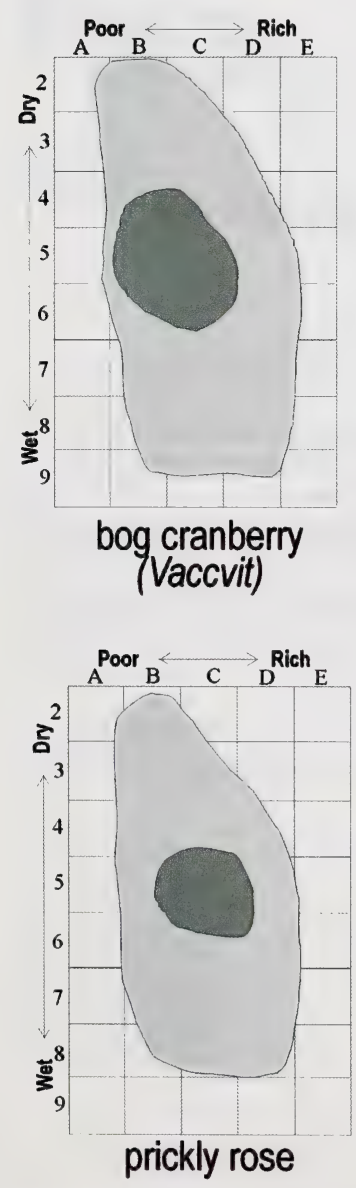

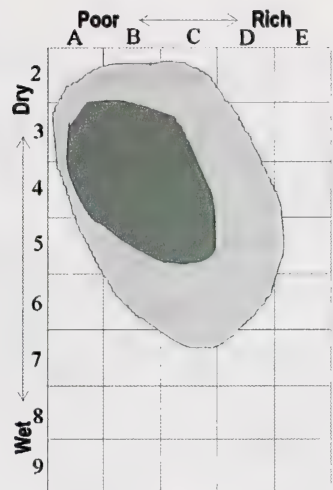

blue berry \& bear berry
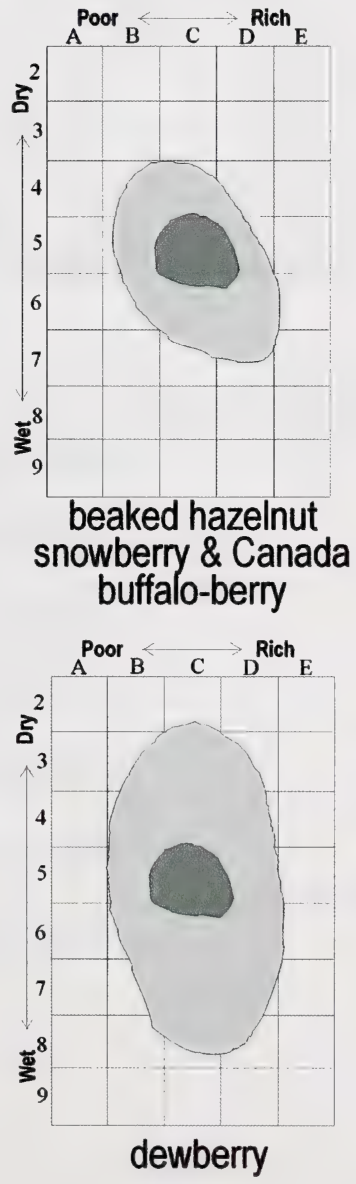
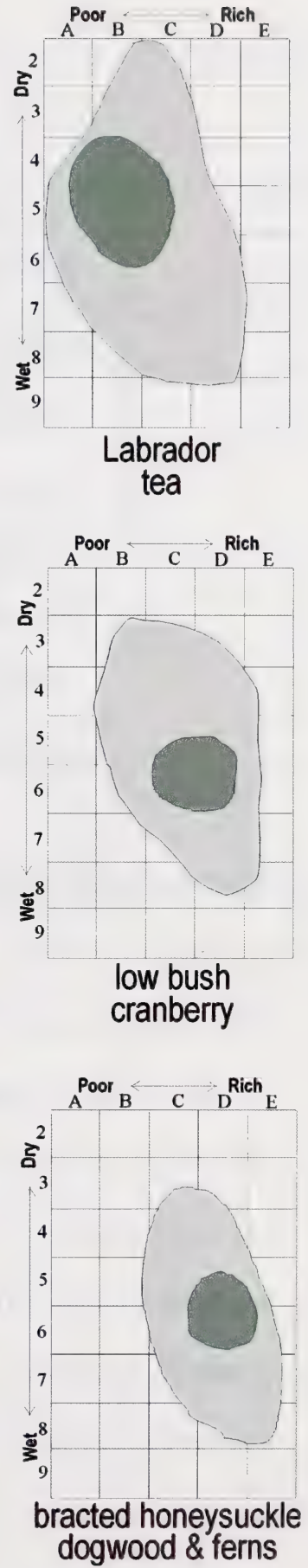

Figure 3B. Selected plant species occurrences relative to moisture and nutrient regimes. 


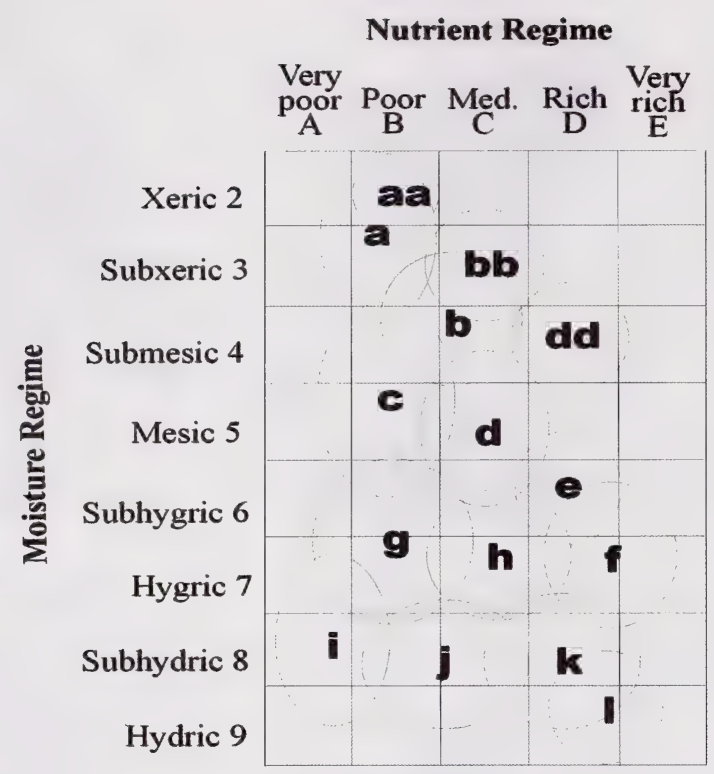

Figure 4. Edatopic grid for the Dry Mixedwood subregion

Ecological sites of the Dry Mixedwood subregion:

f horsetail (hygric/rich)

aa grassland (xeric/poor)

a lichen (subxeric/poor)

g Labrador tea-subhygric (subhygric/poor)

bb grassland (subxeric/medium)

h Labrador tea/horsetail (hygric/medium)

b blueberry (submesic/medium)

i bog (subhygric/very poor)

c Labrador tea-mesic (mesic/poor)

j poor fen (subhydric/medium)

d low-bush cranberry (mesic/medium)

k rich fen (subhydric/rich)

dd grassland (mesic/rich)

1 marsh (hydric/rich)

e dogwood (subhygric/rich) 


\section{Ecological Site "aa" fact sheet}

aa

grass/shrubland $(\mathrm{n}=2)$

\section{GENERAL DESCRIPTION}

This ecosite is associated with small grassy openings within Jack pine and aspen forests. This site has dry conditions, with rapidly drained, nutrient poor soils. The parent materials are generally coarse textured eolian, glacialfluvial or fluvial eolian in origin. The high insolation and dry site conditions favour the growth of grassland species. These include Northern ricegrass, slender wheat grass, Sedge, bearberry and plains wormwood In the moister sites (lower slope positions) aspen and shrubs ( saskatoon, rose) are quite common.

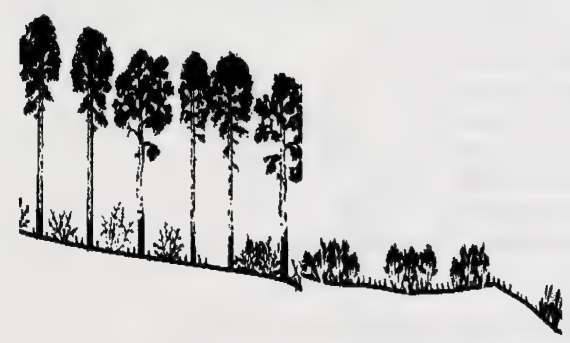

\section{SUCCESSIONAL RELATIONSHIPS}

Due to the nature of the site grasslands often remain the climax vegetation on these sites. In the moister lower slope positions shrubs often dominate the site with succession to aspen and spruce. On the drier hilltops and midslopes grasslands dominated by plains wormwood and northern ricegrass usually represent the climax vegetation. Heavy grazing pressure on the grasslands can often lead to a degraded site that is dominated by kentucky bluegrass on the moister sites.

\section{INDICATOR SPECIES}

\section{Saskatoon}

Rose

Snowberry

Beaked hazelnut

Plains wormwood

Bearberry

Strawberry

Sheep fescue

Northern ricegrass

Slender wheat grass

Hairy wild rye

\section{xeric/poor}

\section{SITE CHARACTERISTICS}

Moisture regime: xeric, subxeric, submesic

Nutrient regime: poor, medium

Topographic position: crest, upper, mid to lower slope Slope: $(0-2 \%)(5-10 \%)$

Aspect: south, southwest, west

\section{SOIL CHARACTERISTICS}

Organic thickness: $(0-2)$

Humus form: mor

Surface texture: SL,L

Effective texture: SL, S

Depth to Mottles/Gley: none

Drainage: rapid, well

Parent material: E, GF,FE,F

Soil subgroup: O.EB, E.DYB O.R, E.EB

\section{ECOLOGICAL SITE PHASES}

aa1 Plains wormwood (2) 
Ecological Site Phase "aa1" fact sheet

aa1 Plains wormwood $(\mathrm{n}=2)$

\section{CHARACTERISTIC SPECIES}

Forb

[8] Scouring rush

[12] Plains wormwood*

[1] Low goldenrod

[1] American vetch

[1] Yellow beardstongue

[10] Common yarrow

Grasses

[18] Sedge species*

[2] Sheep fescue*

[2] Creeping red fescue

[ 5] Kentucky bluegrass

\section{SITE CHARACTERISTICS}

Moisture regime: xeric, subxeric

Nutrient regime: poor,

Topographic position: crest, upper slope, midslope Slope: $5-10 \%, 10-20 \%$

Aspect: westerly, southerly

\section{SOIL CHARACTERISTICS}

Organic thickness: $(0-2)$

Humus form: mor

Surface texture: S, SL

Effective texture: $S$

Depth to Mottles/Gley: none

Drainage: rapid, well

Parent material: E, GF, FE

Soil subgroup: O.R, O.EB, E.EB

RANGE PLANT COMMUNITY TYPES

DMA3. Plains wormwood/Sedge 


\section{Ecological Site "bb" fact sheet \\ bb grassland $(\mathrm{n}=20)$}

\section{GENERAL DESCRIPTION}

This ecosite is associated with the south and west facing slopes along the Peace, Smoky and Wapiti rivers in the Dry Mixedwood subregion of Northwestern Alberta. This site has dry conditions, with rapidly drained, nutrient rich soils. The parent materials are generally glacio lacustrine, morainal, colluvial and fluvial in origin. The high insolation and dry site conditions favour the growth of grassland species. These include Western porcupine grass, Northern wheat grass, Junegrass, Sedge and Fringed sage. In the moister draws aspen and shrubs (snowberry, saskatoon, chokecherry) are quite common.

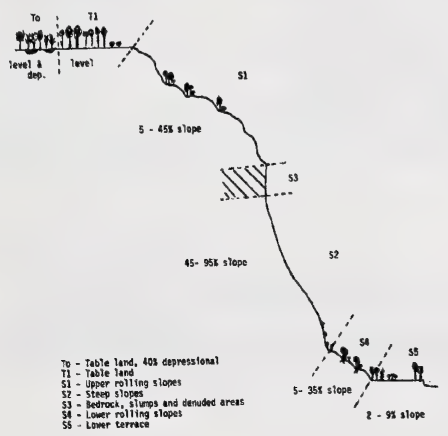

(Adams 1981)

\section{subxeric/medium}

\section{SITE CHARACTERISTICS}

Moisture regime: subxeric, submesic

Nutrient regime: poor, medium, rich

Topographic position: crest, upper slope, midslope

Slope: $27 \%, 45 \%, 90 \%$

Aspect: south, southwest, west

\section{SOIL CHARACTERISTICS}

\author{
Organic thickness: (0-2) \\ Humus form: mull \\ Surface texture: L,CL \\ Effective texture: C, SCL \\ Depth to Mottles/Gley: none \\ Drainage: rapid, well \\ Parent material: GF, M, C, F \\ Soil subgroup: O.BL, R.BL, O.MB, \\ S.GL,CA.DB,O.B,O.EB
}

\section{ECOLOGICAL SITE PHASES}

bbl Western porcupine grass (7)

bb2 Northern wheat grass (13)

\section{SUCCESSIONAL RELATIONSHIPS}

Due to the nature of the site grasslands often remain the climax vegetation on these sites. In the moister draws and lower slope positions aspen and spruce can succeed onto these grasslands. Frequent fire will often control the succession to trees in the moist areas. Heavy grazing pressure on the grasslands can often lead to a degraded site that is dominated by fringed sage, upland sedges and junegrass.

\section{INDICATOR SPECIES}

Western porcupine grass Green needlegrass

Northern wheat grass Saskatoon

Junegrass Snowberry

Upland sedge

Fringed sage 
Ecological Site Phase "bb1" fact sheet

bb1 Western porcupine grass $(n=7)$

\section{CHARACTERISTIC SPECIES}

\section{Shrub}

[8] Fringed sage*
[1]
[2] Saskatoon
Snowberry

Forb

[1] Little leaved everlasting

[1] White camas

[1] Loose flowered milkvetch

[2] Prairie crocus

[1] Wild blue flax

\section{Grasses}

[ 15 ] Western porcupine grass*

[ 15 ] Sedge species*

[5] Green needle grass*

[6] Junegrass*

[1] Western wheat grass

[1] Kentucky bluegrass

[2] Northern wheat grass

\section{SITE CHARACTERISTICS}

Moisture regime: subxeric, submesic

Nutrient regime: medium, rich

Topographic position: crest, upper slope, midslope

Slope: $25-35 \%, 35-72 \%$

Aspect: westerly, southerly

\section{SOIL CHARACTERISTICS}

Organic thickness: (0-2)

Humus form: mull

Surface texture: L,CL

Effective texture: C, SCL

Depth to Mottles/Gley: none

Drainage: rapid, well

Parent material: GF, M, C, F

Soil subgroup: O.BL, R.BL, O.MB, S.GL, CA.DB,O.B,

O.EB

\section{RANGE PLANT COMMUNITY TYPES}

DMA5. Western porcupine grass-Sedge/Fringed sage 


\section{Ecological Site Phase "bb2" fact sheet}

\section{bb2 Northern wheat grass $(n=13)$}

\section{CHARACTERISTIC SPECIES}

\section{Shrub}

[6] Fringed sage*

[6] Saskatoon

[3] Snowberry

[3] Rose

\section{Forb}

[1] Little leaved everlasting

[1] Lindley's aster

[1] Showy locoweed

[1] Cut leaved anemone

[ 1 ] Wild blue flax

[2] Dandelion

\section{Grasses}

[3] Sedge species*

[2] Green needle grass*

[5] Junegrass*

[3] Western wheat grass

[1] Richardson's needlegrass

[ 10] Northern wheat grass*

\section{SITE CHARACTERISTICS}

Moisture regime: xeric, subxeric

Nutrient regime: poor, medium

Topographic position: crest, upper slope, midslope Slope: $10-90 \%$

Aspect: westerly, southerly

\section{SOIL CHARACTERISTICS}

Organic thickness: (0-2)

Humus form: mull

Surface texture: L,CL

Effective texture: $\mathrm{C}, \mathrm{SCL}$

Depth to Mottles/Gley: none

Drainage: rapid, well

Parent material: GF, M, C, F

Soil subgroup: O.R, O.MB, O.EB, O.B, SZ.GL

\section{RANGE PLANT COMMUNITY TYPES}

DMA6. Northern wheat grass-Junegrass/Fringed sage 


\section{Ecological Site Phase "d4" fact sheet}

\section{d4 Saskatoon-Snowberry $(\mathrm{n}=11)$}

\section{CHARACTERISTIC SPECIES}

Tree

[4] Aspen

Shrub

[2] Beaked hazelnut

[ 17] Saskatoon*

[15] Snowberry*

[23 ] Rose*

\section{Forb}

[3] Northern bedstraw

[1] Strawberry

[2] Yellow peavine

[2] Lindley's aster

[2] American vetch

[1] Bearberry

[2] Common yarrow

\section{Grasses}

[4] Sedge species*

[1] Northern ricegrass

[3] Smooth brome

[2] Slender wheat grass*

[1] Kentucky bluegrass

[2] Hairy wild rye

\section{SITE CHARACTERISTICS}

Moisture regime: submesic, mesic

Nutrient regime: medium

Topographic position: lower slope, midslope

Slope: $0-72 \%$

Aspect: westerly, southerly

\section{SOIL CHARACTERISTICS}

Organic thickness: $(0-2)$

Humus form: mor

Surface texture: L, SL

Effective texture: S, SL

Depth to Mottles/Gley: none

Drainage: rapid, well

Parent material: GF, M, C, F, GL

Soil subgroup: O.R, O.MB, O.EB, DG.SO, BR.GL

\section{RANGE PLANT COMMUNITY TYPES}

DMA7. Saskatoon-Snowberry/Hairy wild rye

DMA8. Saskatoon/Sweet clover/Smooth brome 


\section{Ecological Site Phase "d1a" fact sheet}

d1a Grazed Aw (n=66)

\section{CHARACTERISTIC SPECIES}

\section{Tree}

[ 48 ] Aspen*

[1] Balsam poplar

\section{Shrub}

[6] Raspberry

[1] Low bush cranberry

[4] Snowberry

[ 14 ] Rose*

\section{Forb}

[2] Northern bedstraw

[4] Strawberry*

[4] Yellow peavine

[4] Bunchberry*

[3] Lindley's aster

[3] Wild lily-of-the-valley*

[3] Dewberry

[4] Wintergreen*

[1] Dandelion*

[1] Clover species*

\section{Grasses}

[2] Marsh reed grass

[3] Hairy wild rye

[ 1] Purple oat grass*

[2] Slender wheat grass*

[1] Kentucky bluegrass

\section{SITE CHARACTERISTICS}

Moisture regime:, mesic

Nutrient regime: medium

Topographic position: mid, lower slope, level

Slope: $0-5 \%$

Aspect: variable

\section{SOIL CHARACTERISTICS}

Organic thickness: (6-15), (0-5)

Humus form: mor, raw moder

Surface texture: SiL, SL, S, L

Effective texture: C, SiC, CL, SCL, SiCL

Depth to Mottles/Gley: none, (0-25)

Drainage: well, mod. well, imperfect

Parent material: GF, M, GL

Soil subgroup: O.GL, GR.GL, GL.GL

\section{RANGE PLANT COMMUNITY TYPES}

DMC3. Aw/Rose/Low forb

DMC3a. Aw-Pb/Dandelion/Kentucky bluegrass 


\section{Ecological Site Phase "d1b" fact sheet}

\section{d1b Harvested Aw (n=4)}

\section{CHARACTERISTIC SPECIES}

Tree

[ 20 ] Aspen

[1] Balsam poplar

Shrub

[5] Raspberry

[2] Saskatoon

[3] Snowberry

[ 19] Rose

[2] Low bush cranberry

Forb

[4] Northern bedstraw

[21 ] Strawberry

[1] Yellow peavine

[4] Lindley's aster

[1] American vetch

[4] Fireweed

[1] Bunchberry

\section{Grasses}

[17] Marsh reed grass

[2] Northern ricegrass

[1] Hairy wild rye

[1] Slender wheat grass

[2] Timothy

\section{SITE CHARACTERISTICS}

Moisture regime: mesic

Nutrient regime: medium

Topographic position: mid, lower slope, level

Slope: $0-5 \%$

Aspect: variable

\section{SOIL CHARACTERISTICS}

Organic thickness: (6-15), (0-5)

Humus form: mor, raw moder

Surface texture: SiL, SL, S, L

Effective texture: C, SiC, CL, SCL, SiCL

Depth to Mottles/Gley: none, (0-25)

Drainage: well, mod. well, imperfect

Parent material: GF, M, GL

Soil subgroup: O.GL, GR.GL, GL.GL

\section{RANGE PLANT COMMUNITY TYPES}

DMC10. Deciduous cutblocks 


\section{Ecological Site "dd" fact sheet}

\section{dd grassland $(\mathrm{n}=6)$}

\section{GENERAL DESCRIPTION}

This ecosite is associated with the remnant prairies located throughout the Peace River district of Alberta. This site is associated with the dark colored solonetzic and chernomzic soils of the region. The parent materials are generally fine textured, slightly saline, fluvial, lacustrine or lacustrinetill in origin. The hard impermeable B horizon and slightly saline conditions tend to favour the growth of grassland species. These include Western porcupine grass, slender wheat grass, sedge, California oat grass and fringed sage Trees appear to be gradually moving into the old prairie remnants where the unfavorable characteristics of the solonetzic soils have been improved from many of the agricultural practices in the area.

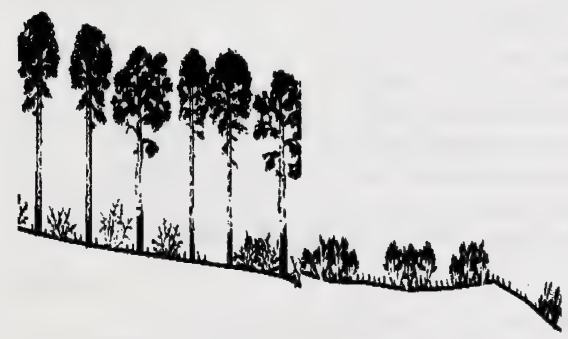

\section{SUCCESSIONAL RELATIONSHIPS}

Due to the nature of the site grasslands often remain the climax vegetation on these sites. However, industrial activities have greatly modified the original vegetation cover. Heavy grazing pressure on the remnant grasslands can often lead to a degraded site that is dominated by purple oat grass, sedge, Kentucky bluegrass, dandelion and smooth brome.

\section{INDICATOR SPECIES}

Saskatoon

California oat grass

Rose

Sedge species

Snowberry

Kentucky bluegrass

Strawberry

Slender wheat grass

Veiny meadow rue

Western porcupine grass

Dandelion

Purple oat grass

Common yarrow

\section{mesic/rich}

\section{SITE CHARACTERISTICS}

Moisture regime: mesic, submesic

Nutrient regime: medium, rich

Topographic position: level, lower slope

Slope: $(0-5 \%)$

Aspect: south, southwest, west

\section{SOIL CHARACTERISTICS}

Organic thickness: (0-5)

Humus form: mull

Surface texture: $\mathrm{L}, \mathrm{SiCL}$

Effective texture: $\mathrm{C}, \mathrm{CL}$

Depth to Mottles/Gley: none

Drainage: well, mod. well

Parent material: L

Soil subgroup: DB.SO, BL.SO, DB.SS, BL.SS, O.DB, R.DB

\section{ECOLOGICAL SITE PHASES}

dd1 california oat grass-slender wheat grass 


\section{Ecological Site Phase "dd1" fact sheet}

dd1 california oat grass-slender wheat

grass $(n=6)$

\section{CHARACTERISTIC SPECIES}

Shrub

[1] Saskatoon

[8] Snowberry*

[4] Rose

\section{Forb}

[2] Northern bedstraw

[9] Strawberry

[5] Common yarrow

[1] Three flowered avens

[5] Dandelion

[10] Veiny meadow rue*

[4] American vetch

\section{Grasses}

[6] California oat grass*

[7] Western porcupine grass*

[9] Sedge species*

[ 14] Slender wheat grass*

[8] Kentucky bluegrass

[3] Junegrass

[ 17 ] Purple oat grass*

\section{SITE CHARACTERISTICS}

Moisture regime: mesic, submesic

Nutrient regime: medium, rich

Topographic position: level, lower slope

Slope: $(0-5 \%)$

Aspect: south, southwest, west

\section{SOIL CHARACTERISTICS}

Organic thickness: $(0-5)$

Humus form: mull

Surface texture: $\mathrm{L}$, SiCL

Effective texture: $\mathrm{C}, \mathrm{CL}$

Depth to Mottles/Gley: none

Drainage: well, mod. well

Parent material: L

Soil subgroup: DB.SO, BL.SO, DB.SS, BL.SS

\section{RANGE PLANT COMMUNITY TYPES}

DMA4. Purple oat grass-California oat grass-Sedge DMA4a. Veiny meadow rue/Slender wheat grass-Fringed brome 


\section{Ecological Site Phase "e4" fact sheet}

e4 dogwood shrubland $(\mathrm{n}=10)$

\section{CHARACTERISTIC SPECIES}

\section{Trees}

[1] Balsam poplar

Shrub

\author{
[25] Red osier dogwood \\ [5] Snowberry* \\ [9] Rose \\ [ 32 ] Silverberry
}

\section{Forb}
[2] Horsetail
[3] Strawberry
[1] Common yarrow
[3] Veiny meadow rue*
[2] American vetch

\section{Grasses}
[3] Smooth brome
[ 3 ] Marsh reed grass
[1 ] Sedge species*
[2] Kentucky bluegrass

\section{SITE CHARACTERISTICS}

Moisture regime: mesic, subhygric

Nutrient regime: rich

Topographic position: level, lower slope

Slope: $(0-5 \%)$

Aspect: variable

\section{SOIL CHARACTERISTICS}

Organic thickness: (6-15)

Humus form: mor

Surface texture: $\mathrm{SiL}, \mathrm{Si}, \mathrm{SiC}, \mathrm{CL}$

Effective texture: $\mathrm{SiC}, \mathrm{C}$,

Depth to Mottles/Gley: (0-25)

Drainage: imperfect, poor, mod. well, well

Parent material: F, GL, M

Soil subgroup: O.LG, O.G, CU.R, GLCU.R

\section{RANGE PLANT COMMUNITY TYPES}

DMA17. Red osier dogwood/Marsh reed grass

DMA18. Silverberry/Smooth brome 
Ecological Site Phase "f4" fact sheet

f4 horsetail/ Willow $(\mathrm{n}=39)$

\section{CHARACTERISTIC SPECIES}

Shrub

[65] Willow*

[1] Bracted honeysuckle

[ 10 ] Rose

Forb

[ 18 ] Horsetail*

[9] Arrow leaved coltsfoot

[8] Lindley's aster

[8] Bishop's cap

[5] Strawberry

[4] Veiny meadow rue

[4] Dewberry

[2] Fireweed

\section{Grasses}

[ 23 ] Marsh reed grass*

[ 1 ] Hair-like sedge

[2] Slender wheat grass

\section{SITE CHARACTERISTICS}

Moisture regime: subhygric, hygric, mesic

Nutrient regime: rich, medium

Topographic position: level, lower slope, toe

Slope: level (2-5\%)

Aspect: level, northerly

\section{SOIL CHARACTERISTICS}

Organic thickness: (6-15)

Humus form: mor

Surface texture: $\mathrm{SiL}, \mathrm{Si}, \mathrm{SiC}, \mathrm{CL}$

Effective texture: $\mathrm{SiC}, \mathrm{C}$,

Depth to Mottles/Gley: (0-25)

Drainage: imperfect, poor, mod. well, well

Parent material: F, GL, M

Soil subgroup: O.LG, O.G, CU.R, GLCU.R

\section{RANGE PLANT COMMUNITY TYPES}

DMA12. Willow/Horsetail/Marsh reed grass DMA15. Sandbar willow

DMA16. Bebb willow/Marsh reed grass 


\section{Ecological Site Phase "f5" fact sheet}

\section{f5 horsetail/ Bw (n=6)}

\section{CHARACTERISTIC SPECIES}

Tree

[25] Paper birch*

[5] Larch

[3] White spruce

Shrub

[ 8 ] Bracted honeysuckle

[ 45] River alder*

[3] Willow

Forb

[27 ] Horsetail*

[6] Dewberry

[5] Bishop's cap

[3] Twinflower

[2] Sweet scented bedstraw

[1] Purple-stemmed aster

[1] American vetch

\section{Grasses}

[ 9 ] Marsh reed grass*

[2] Sedge species

\section{SITE CHARACTERISTICS}

Moisture regime: subhygric, hygric, mesic

Nutrient regime: rich, medium

Topographic position: level, lower slope, toe

Slope: level (2-5\%)

Aspect: level, northerly

\section{SOIL CHARACTERISTICS}

Organic thickness: (6-15)

Humus form: mor

Surface texture: $\mathrm{SiL}, \mathrm{Si}, \mathrm{SiC}, \mathrm{CL}$

Effective texture: $\mathrm{SiC}, \mathrm{C}$,

Depth to Mottles/Gley: (0-25)

Drainage: imperfect, poor, mod. well, well

Parent material: F, GL, M

Soil subgroup: O.LG, O.G, CU.R, GLCU.R

RANGE PLANT COMMUNITY TYPES

DMA13. River alder/Horsetail 


\section{Ecological Site Phase "g2" fact sheet}

g2 saline $(\mathrm{n}=11)$

\section{CHARACTERISTIC SPECIES}

\section{Shrub}

[1] Sandbar willow

\section{Forb}

[1] Sea side arrowgrass

[1] Sea side buttercup

[1] Horsetail

\section{Grasses}

[ 12] Rush species

[ 20] Three square rush

[ 30 ] Prairie bulrush

[ 30 ] Nuttall's saltgrass

[25] Foxtail barley

\section{SITE CHARACTERISTICS}

Moisture regime: subhydric, hygric, hydric

Nutrient regime: medium, poor

Topographic position: level, lower slope, toe

Slope: level (2-5\%)

Aspect: level, northerly

\section{SOIL CHARACTERISTICS}

Organic thickness: $>80$

Humus form:

Surface texture: fibric, mesic

Effective texture: fibric, mesic, humic

Depth to Mottles/Gley: (0-25)

Drainage: imperfect, poor, very poor

Parent material: $\mathrm{O}, \mathrm{M}$

Soil subgroup: TY.M, R.G, TY.F, THU.M, R.HG, ME.OC

-

RANGE PLANT COMMUNITY TYPES

DMA25. Rush meadow

DMA27. Three square rush

DMA28. Prairie bulrush

DMA29. Nuttall's saltgrass

DMA30. Foxtail barley 


\section{Ecological Site Phase "j3" fact sheet}

\section{j3 grassland poor fen $(\mathrm{n}=5)$}

\section{CHARACTERISTIC SPECIES}

Shrub

[6] Bog willow

[1] Bog birch

Forb

[7] Buckbean

[5] Marsh cinquefoil

[3] Marsh marigold

\section{Grasses}

[ 82 ] Two stamened sedge

[1] Water sedge

\section{SITE CHARACTERISTICS}

Moisture regime: subhydric, hygric, hydric

Nutrient regime: medium, poor

Topographic position: level, lower slope, toe

Slope: level (2-5\%)

Aspect: level, northerly

\section{SOIL CHARACTERISTICS}

Organic thickness: $>80$

Humus form:

Surface texture: fibric, mesic

Effective texture: fibric, mesic, humic

Depth to Mottles/Gley: (0-25)

Drainage: imperfect, poor, very poor

Parent material: $\mathrm{O}, \mathrm{M}$

Soil subgroup: TY.M, R.G, TY.F, THU.M, R.HG, ME.OC

RANGE PLANT COMMUNITY TYPES

DMA24. Two stamened sedge 


\section{Ecological Site Phase "k2a" fact sheet}

\section{k2a grazed Willow (n=13)}

\section{CHARACTERISTIC SPECIES}

Tree

[1] Balsam poplar

Shrub

[1] Rose

[14] Willow*

Forb
[22] Dandelion*
[ 1 ] Clover*
[2] Mint
[1] Plantain

\section{Grasses}
[ 16] Kentucky bluegrass*
[ 12] Marsh reed grass
[ 1 ] Foxtail barley
[1] Sedge species

\section{SITE CHARACTERISTICS}

Moisture regime: hydric, subhydric, hygric

Nutrient regime: rich, medium, very rich

Topographic position: level, depression

Slope: level, $(2-5 \%)$

Aspect: level

\section{SOIL CHARACTERISTICS}

Organic thickness: $>80,(6-15)$

Humus form: peatymor

Surface texture: fibric, C, mesic, SiL, humic

Effective texture: mesic, $\mathrm{C}$,hC,fibric,SiC, humic

Depth to Mottles/Gley: (0-25)

Drainage: very poor, poor

Parent material: O, GL, L

Soil subgroup: R.G, R.HG, TY.F, O.F

\section{RANGE PLANT COMMUNITY TYPES}

DMA11. Willow/Marsh reed grass-Kentucky bluegrass DMA14. Willow/Kentucky bluegrass/Dandelion 


\section{Ecological Site Phase "k3a" fact sheet}

k3a grazed meadow $(n=2)$

\section{CHARACTERISTIC SPECIES}

\section{Forb}
[60] Dandelion*
[14] Strawberry*
[12] Yellow peavine
[11] Common yarrow
[7] Horsetail
[3] Smooth aster
[3] American vetch

\section{Grasses}
[ 18 ] Kentucky bluegrass*
[ 16] Rough hairgrass
[5] Slender wheat grass
[4] Fringed brome
[2] Sedge species

\section{SITE CHARACTERISTICS}

Moisture regime: hydric, subhydric, hygric

Nutrient regime: rich, medium, very rich

Topographic position: level, depression

Slope: level, (2-5\%)

Aspect: level

\section{SOIL CHARACTERISTICS}

Organic thickness: $>80,(6-15)$

Humus form: peatymor

Surface texture: fibric, C, mesic, SiL, humic

Effective texture: mesic, $\mathrm{C}$,hC,fibric, $\mathrm{SiC}$, humic

Depth to Mottles/Gley: (0-25)

Drainage: very poor, poor

Parent material: O, GL, L

Soil subgroup: R.G, R.HG, TY.F, O.F

\section{RANGE PLANT COMMUNITY TYPES}

DMA9. Kentucky bluegrass-Rough hairgrass 


\section{DRY MIXEDWOOD SUBREGION GRASSLAND AND SHRUBLAND COMMUNITY TYPES}

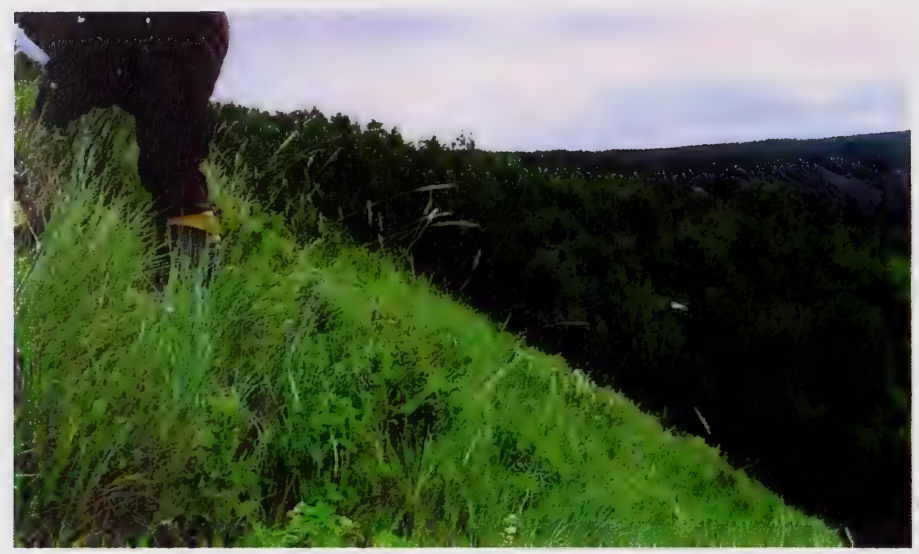

Photo 1. The Western porcupine grass-Sedge/Fringed sage community is found throughout the Dry Mixedwood subregion on the south-facing slopes of the Smoky, Wapiti and Peace Rivers. This community provides early spring forage for both wildlife and cattle.

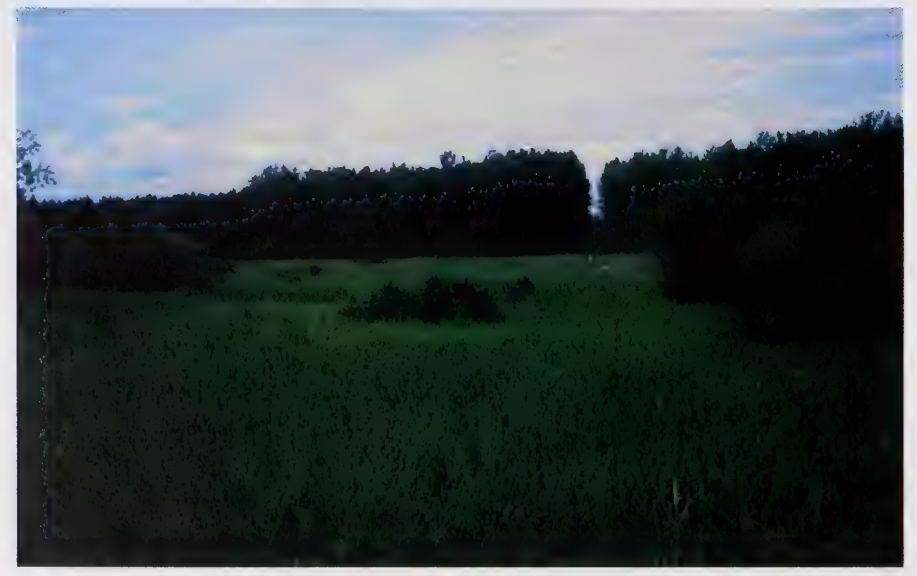

Photo 2. This picture represents the transition from sedge-marsh reed grass meadows to willow sedge dominated community types in the Dry Mixedwood subregion. These community types provide a large amount of forage, but the moist conditions limit their use by livestock. 


\section{NATIVE GRASS AND SHRUBLAND COMMUNITIES}

The Dry Mixedwood subregion represents the transition between the Boreal forest and Parkland subregions. Aspen Parkland-like vegetation can develop where site conditions or drought conditions occur in combination with the driest climatic conditions (Strong 1992). The Grande Prairie area is an example where a number of these conditions occur. It is within this area that a number of native upland grassland community types have been described. On steep, south-facing slopes of the Smoky, Wapiti and Peace Rivers with subxeric moisture regimes and medium nutrient regimes the Western porcupine grass-Sedge/Fringed sage and Northern wheat grass/Fringed sage community types are common (Figure 1). The Purple oat grass-SedgeCalifornia oat grass community type is found on more upland sites with mesic moisture and medium nutrient regimes. Wilkinson and Johnston (1983) felt these grasslands to be the climax community type on Solonetzic soils. Indeed, Adams (1981) found the Western porcupine grassSedge dominated community on the Peace River slopes to be associated with Dark Gray Solods and Solonetzic Gray Luvisols. These grasslands provide important forage locally for both wildlife and domestic livestock. The grasslands of the south-facing river slopes are important spring forage sources because of early spring green-up.

On coarse textured, sandy soil, with submesic moisture and poor nutrient regimes which lack tree cover are found the Plains wormwood/Sedge and Saskatoon/Bearberry/Northern ricegrass community types. These community types are usually found in association with Jack pine dominated community types.

Wet freshwater (subhydric/rich) sites are associated with sedge, bulrush, cattail, creeping spike rush, swamp horsetail, common reed grass, tall manna grass and marsh reed grass dominated meadows. Sedge, bulrush, cattail, creeping spike rush, common reed grass, tall manna grass and swamp horsetail species are usually associated with the areas of free standing water and reed grass species tend to dominate the drier edges. Flat leaved willow and basket willow will invade into these meadows to form the Willow/Sedge and Willow/Marsh reed grass community types. Rich, subhygric upland sites with better drainage are often dominated by Scouler's willow, Bebb's willow or red osier dogwood. These sites will often become dominated by trees in the absence of disturbance.

Boggy and acidic sites are often dominated by two stamened sedge and bog willow and will undergo succession to black spruce and larch in the absence of disturbance. A number of saline and alkaline sites were described in the Dry Mixedwood subregion. These sites are dominated by rush species, prairie bulrush, Nuttall's salt meadow grass, foxtail barley or three square rush. These saline communities are more common in the eastern part of the subregion. 


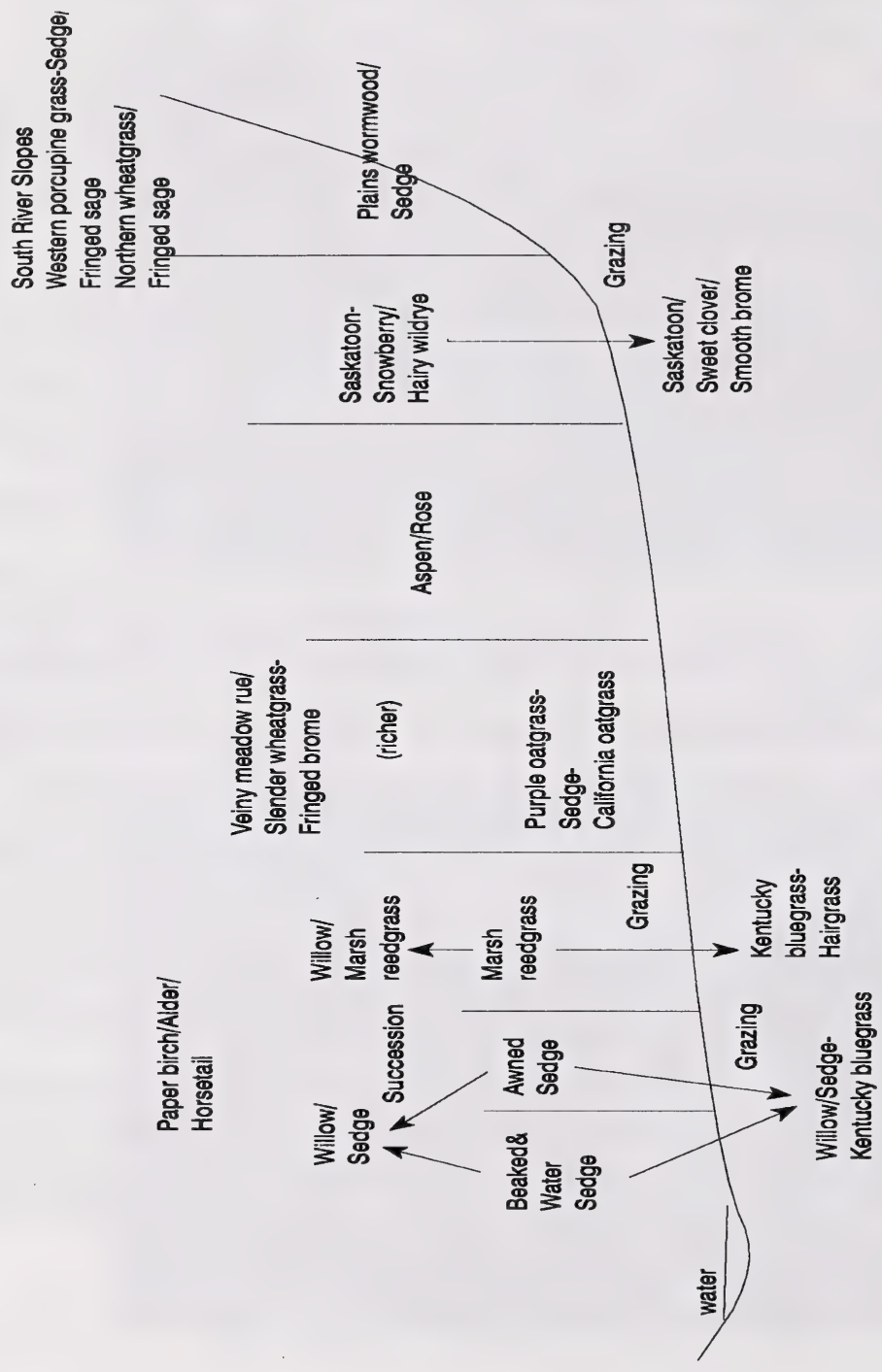

Figure 5. Overview of native grass and shrubland complex in the Dry Mixedwood subregion. 


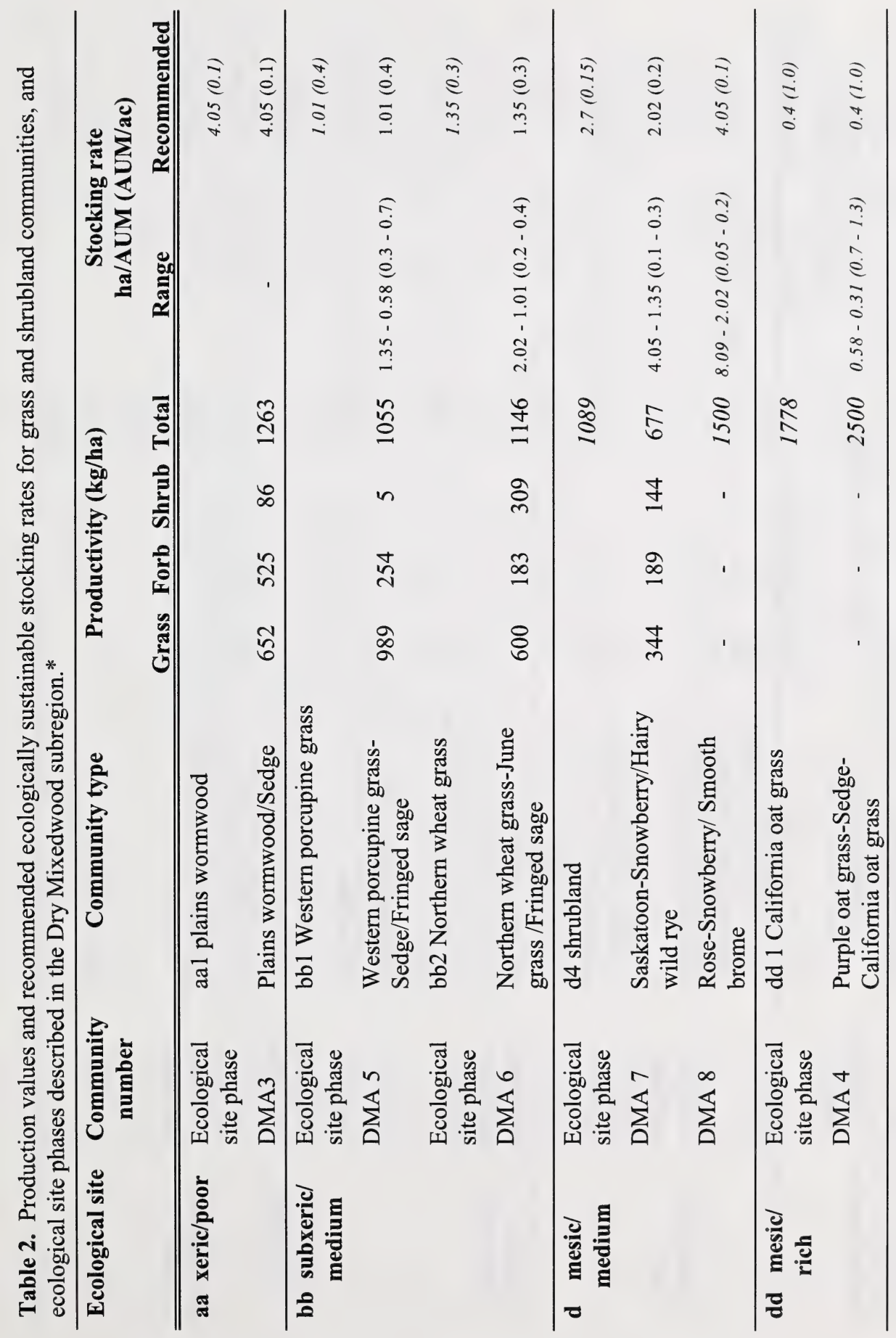




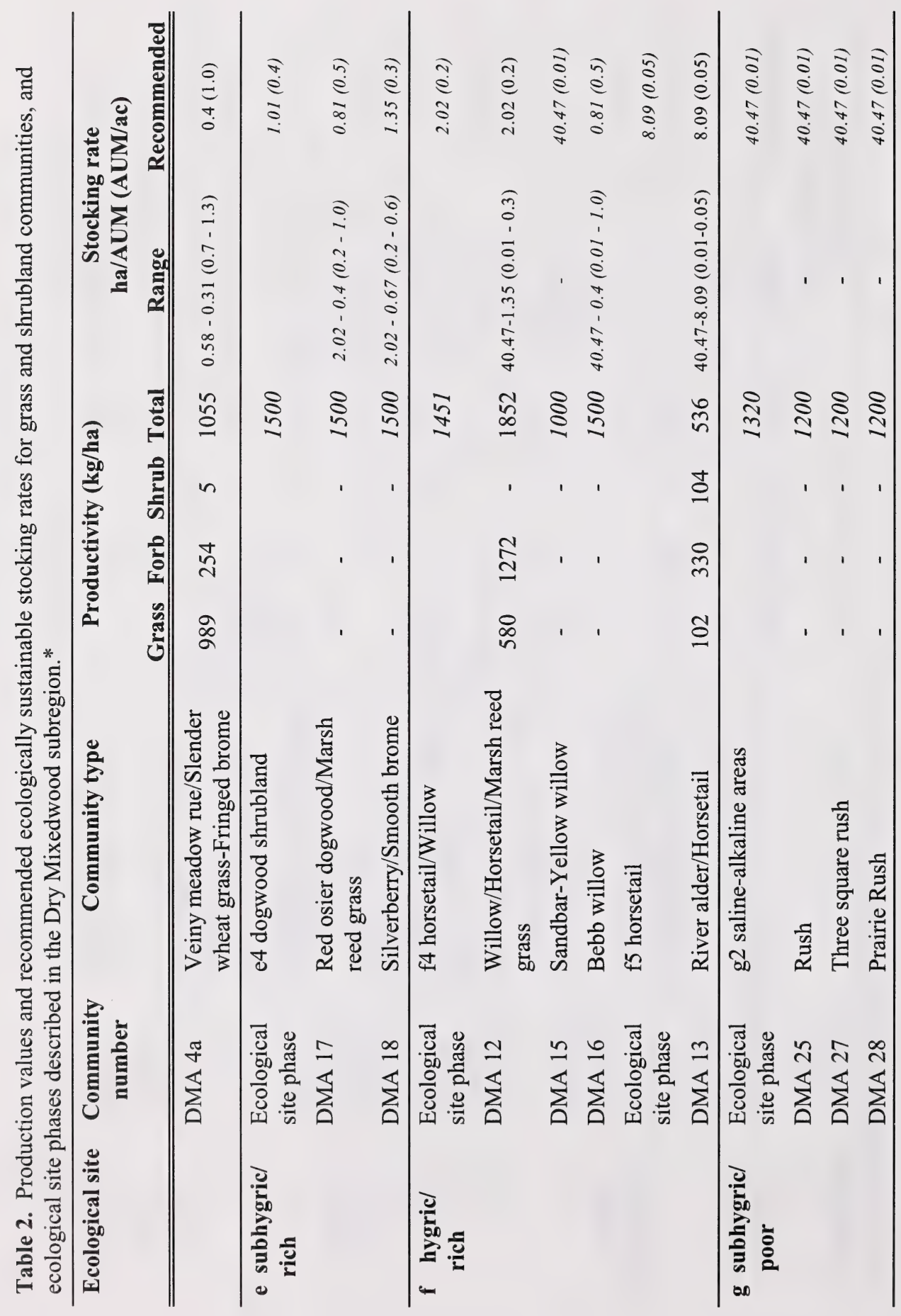




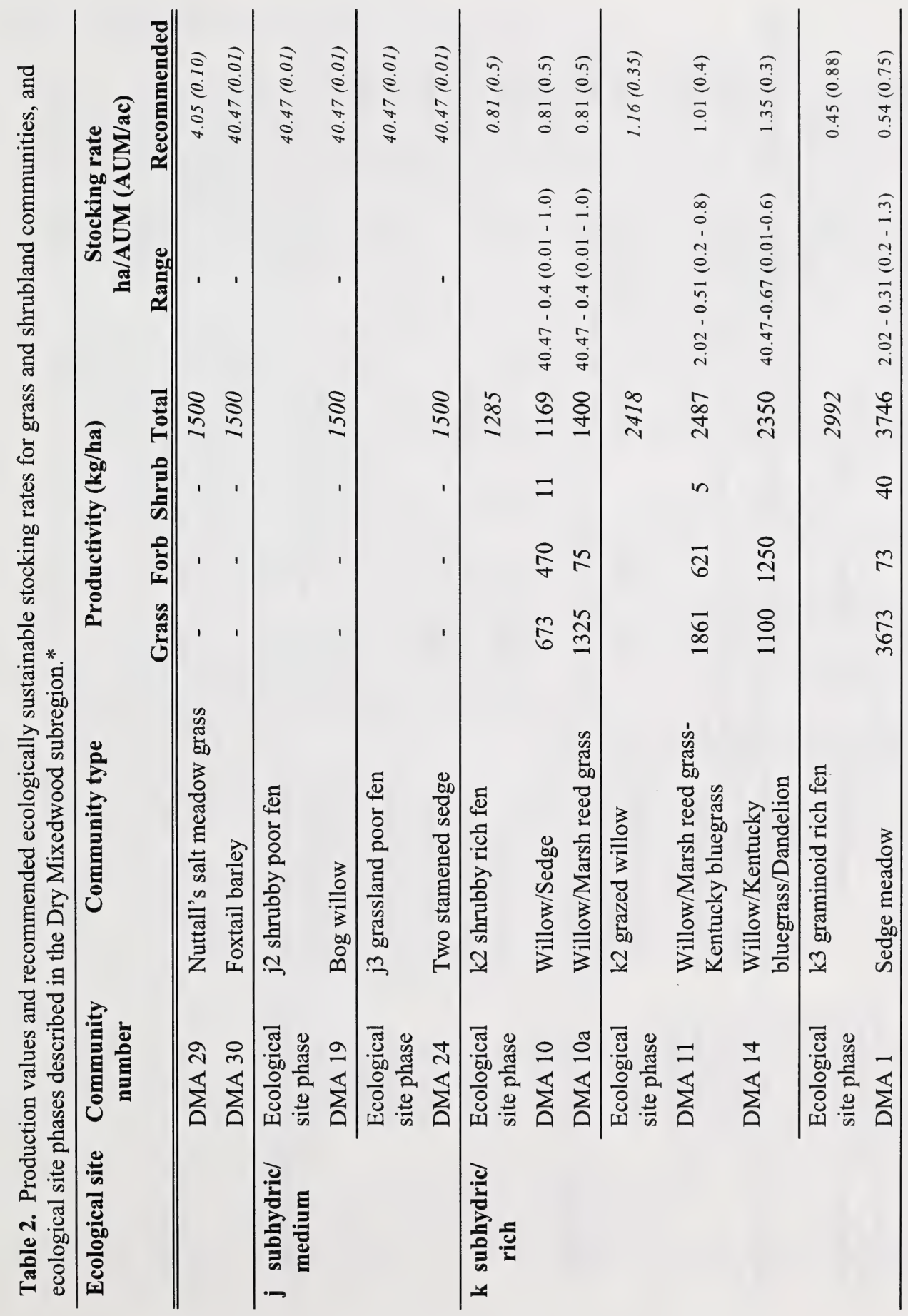




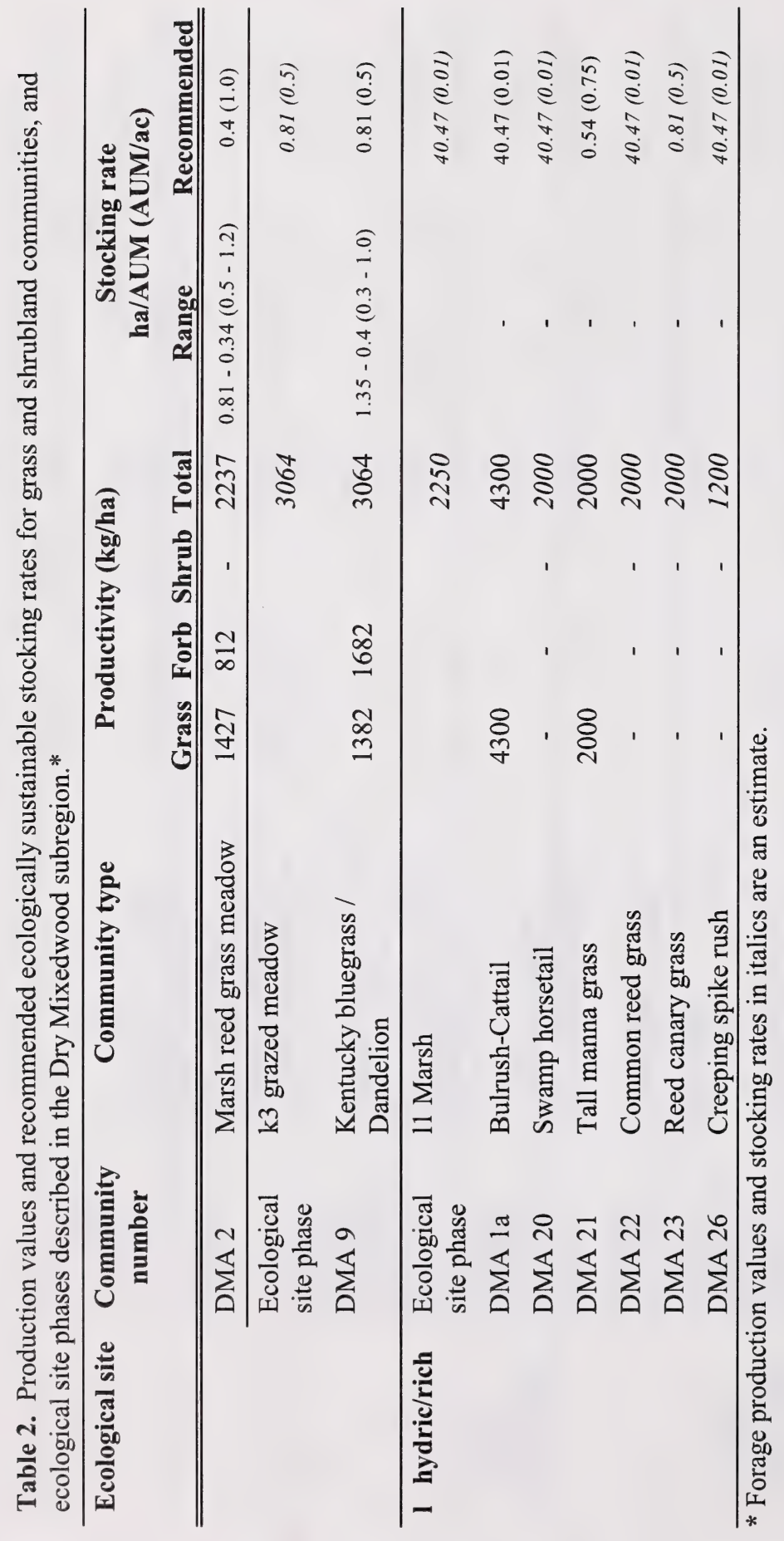




\section{Key to Grass and Shrublands}

1. Shrub dominated site, by willow, bog birch, silverberry, river alder or dogwood............................ . . 2 Grass or grass-likes dominated ( $<20 \%$ cover from shrubs) or if shrub-dominated by upland species like hazelnut, saskatoon, or rose.

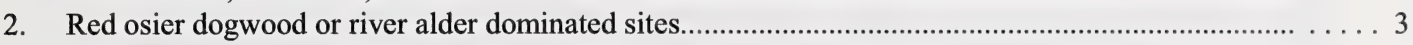

Willow or silverberry dominated community types, sedge, marsh reed grass, horsetail dominate the herbaceous layer

3. Red osier dogwood dominated community.........Red osier dogwood/Marsh reed grass (DMA17)

River alder dominated community.

River alder/Horsetail (DMA13)

4. Heavily grazed community types dominated by grazing resistant species in the herbaceous

layer.

Willow/Kentucky bluegrass/Dandelion (DMA14)

Lightly or moderately grazed sites with the herbaceous layer dominated by native species............. . . . 5

5. Horsetail dominates the herbaceous layer............Willow/Horsetail/Marsh reed grass (DMA12)

Sedges or marsh reed grass dominate the herbaceous layer.

6. Wetland sedge species dominate the herbaceous layer.................................llow/Sedge (DMA10)

Upland sites dominated by willow or silverberry or boggy sites and riparian areas dominated by yellow

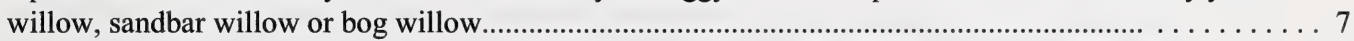

7. Sites dominated by marsh reed grass in the herbaceous layer.......................................................... 8

Willow or silverberry dominated uplands, willow dominated riparian areas, or boggy areas............... . 9

8. Marsh reed grass dominates the herbaceous layer................Willow/Marsh reed grass (DMA10a)

Kentucky bluegrass dominant or co-dominant in the herbaceous layer.

..Willow/Marsh reed grass-Kentucky bluegrass (DMA11)

9. Riparian areas dominated by sandbar and yellow willow.........Sandbar-Yellow willow (DMA15)

Upland sites dominated by Bebb willow, silverberry or boggy sites dominated by bog willow...... . . . 10

10. Boggy sites dominated by Bog willow.

Bog willow (DMA19)

Upland sites dominated by Bebb willow or silverberry.

11. Bebb willow dominated.

Silverberry dominated.

Bebb willow/Marsh reed grass (DMA16)

..Silverberry/Smooth brome (DMA18)

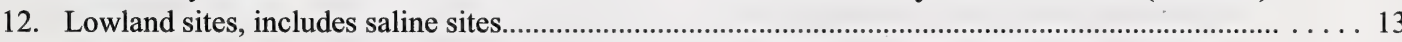

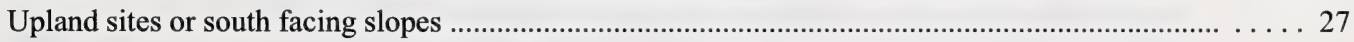

13. Sites dominated by invasive species.............................Kentucky bluegrass/Dandelion (DMA9)

Sites dominated by native species.

14. Saline sites dominated by salt tolerant species (e.g. three square rush, foxtail barley,

Nuttall's salt meadow grass, baltic rush) .................................................................................. 15

Non-saline sites dominated by other wetland species (e.g. cattails, sedges, reed grasses)................ . . 19

15. Salt tolerant bulrush (Scirpus species) dominated sites.............................................................. . . 16

Nuttall's salt meadow grass, foxtail barley, or rush dominated................................................ . . 17

16. Prairie bulrush dominated.

Prairie bulrush (DMA28)

Three square rush dominated

Three square rush (DMA27)

17. Nuttall's salt meadow grass dominated.

Foxtail barley or baltic rush dominated. .Nuttall's salt meadow grass (DMA29)

18. Site dominated by foxtail barley

Baltic rush dominated meadow.

Rush meadow (DMA25)

19. Wet sites, dominated by sedge and marsh, narrow or northern reed grass .................................... 20

Very wet sites with standing water; cattails, bulrush, swamp horsetail, tall manna grass,

common reed grass, reed canary grass, or creeping spike rush present

20. Drier sites dominated by marsh reed grass

Marsh reed grass meadow (DMA2)

Wet sites dominated by wetland sedge species. 
21. Boggy sites; poor to medium nutrient levels; dominated by two stamened sedge. ..Two stamened sedge (DMA24)

Fresh water sites; rich in nutrients; dominated by beaked, water, or awned sedge...

22. Common great bulrush or cattail dominated sites Sedge meadows (DMA1) Drier sites, edge communities near free standing water Bulrush-Cattail (DMA1a)

23. Common reed grass or reed canary grass dominated Tall manna grass, Creeping spike rush or swamp horsetail dominated

24. Common reed grass (Phragmites)dominated. Reed canary grass dominated. Common reed grass (DMA22)

25. Swamp horsetail dominated. Reed canary grass (DMA23)

Tall manna grass or creeping spike rush dominated. Swamp horsetail (DMA20)

26. Tall manna grass dominated Tall manna grass (DMA21) Creeping spike rush dominated Creeping spike rush (DMA26)

27. South facing (river) slopes 28

Open meadows and grasslands, or upland shrublands situated among forested stands. 26

28. Moderate slopes; the dominate grass is western porcupine grass

Western porcupine grass-Sedge/Fringed sage (DMA5)

Very steep slopes or grazing modified communities; western porcupine grass is absent/replaced by northern wheat grass.

Northern wheat grass-Junegrass/Fringed sage (DMA6)

29. Mesic sites with medium to rich nutrient soils; white spruce may be present. 30

Upland sandy sites with poorer nutrient status; grasslands interspersed among jack pine or aspen.

30. Mesic medium sites dominated by purple oat grass, sedge, and California oat grass

Purple oat grass-Sedge-California oat grass (DMA4)

Richer sites, veiny meadow rue, slender wheat grass, and fringed brome dominate Veiny meadow rue/Slender wheat grass-Fringed brome (DMA4a)

31. Very dry south facing hilltops dominated by Plains wormwood and upland sedge species, generally lacking shrub cover .Plains wormwood/Sedge (DMA3) Moister sites dominated by other species 32

32. Sites dominated by native herbaceous species and saskatoon and/or snowberry

Saskatoon-Snowberry/Hairy wild rye (DMA7)

Sites dominated by grazing resistant or invasive herbaceous species

.Rose-Snowberry/Smooth brome (DMA8) 


\section{DMA1. Sedge meadows \\ (Carex aquatilis, $C$. rostrata, C. atherodes)}

$\mathbf{n = 4 1}$ This wetland community type is found near fresh water and can be dominated by water sedge, beaked sedge or awned sedge. The sedge meadow is a poorly drained community. As one moves to the drier edges marsh reed grass becomes predominant. Willows will invade into both the sedge and marsh reed grass dominated meadows. The sedge meadow community is very productive, but the high water table, particularly in the spring when the sedge species are most palatable, restricts livestock movement. One study done in the Yukon found that crude protein on these meadows declined from a high of $10 \%$ in May to less than 5\% in September (Bailey et al. 1992).

Beaked sedge found in abundance in this community is usually associated with nitrogen rich conditions and moving water (Brierly et al. 1985). Water sedge is often found in abundance in this community type and is associated with calcium rich stagnant water (MacKinnon et al. 1992).

\section{PLANT COMPOSITION Canopy Cover(\%)}

$$
\text { MEAN RANGE CONST. }
$$

\section{SHRUBS}

WILLOW SPP.

(Salix spp.)

\section{FORBS}

MARSH WILLOWHERB

(Epilobium palustris)

Dock

(Rumex acetosa)

SKULl CAP

(Scutellaria galericulata)

MINT

(Mentha arvensis)

$2 \quad 0-30 \quad 44$

\section{GRASSES}

BEAKED SEDGE

(Carex rostrata)

AWNED SEDGE

(Carex atherodes)

WATER SEDGE

(Carex aquatilis)

MARSH REED GRASS

(Calamagrostis canadensis)

$23 \quad 0-85 \quad 56$

$35 \quad 0-97 \quad 65$

$21 \quad 0-90 \quad 51$

0-11 17

\section{ENVIRONMENTAL VARIABLES}

Moisture Regime (MEAN):

SUBHYDRIC-HYGRIC

NUTRIENT REGIME (MEAN):

RICH

ELEVATION: 586(579-600) M

SoIl Drainage (MEAN):

POORLY TO VERY POORLY

ECOLOGICAL STATUS SCORE: 24

HEALTH FORM: RIPARIAN

\section{FORAGE PRODUCTION (KG/HA)}
GRASS
FORB
3673(1054-5028)
SHRUB
$73(0-80)$
TOTAL
$40(0-120)$
3746(1254-5028)

ECOLOGICALLY SUSTAINABLE STOCKING RATE

$0.54 \mathrm{ha} / \mathrm{AUM}(2.02-0.31)$

$0.75 \mathrm{AUM} / \mathrm{ac}(0.2-1.3)$ 


\section{DMA1a. Bulrush-Cattail \\ (Scirpus acutus-Typha latifolia)}

$\mathbf{n = 1 8}$ This wetland community type is associated with standing water. This community is an emergent community found in standing water of ponds and sloughs. As one moves away from the water to the drier edges the sedge meadow communities are found. On the drier edges the marsh reed grass community is found and willow are associated in the transition from the slough margin and the forest.

\section{Plant Composition Canopy Cover(\%)}

\section{FORBS}

ARUM-LEAVED ARROW HEAD $\begin{array}{ll}\text { (Sagittaria cuneata) } & 1 \\ \text { NARROW LEAVED BURREED } & \\ \text { (Sparganium eurycarpium) } & 9\end{array}$

BULB BEARING WATER HEMLOCK

$\begin{array}{llll}\text { (Cicuta bulbifera) } & 1 & 0-3 & 11\end{array}$

\section{GraSSES}

COMMON GREAT BULRUSH (Scripus validus)

GREAT BULRUSH

(Scirpus acutus)

CATTAIL

(Typha latifolia)

CREEPING SPIKE RUSH

(Eleocharis palustris)

SPANGLETOP

(Scholochloa festucacae)

$1 \quad 0-3 \quad 17$

$0-80 \quad 11$

11

$\begin{array}{lll}6 & 0-60 & 11 \\ 29 & 0-90 & 44 \\ 27 & 0-97 & 50 \\ 3 & 0-4 & 22 \\ 5 & 0-97 & 5\end{array}$

\section{ENVIRONMENTAL VARIABLES}

MoistuRE REgIME (MEAN): SUBHYDRIC-HYGRIC

NutriEnt REgIME (MEAN $\mathrm{RICH}$

ELEVATION: $606 \mathrm{M}$

SoIL DRAINAGE (MEAN): VERY POORLY

ECOLOGICAL STATUS SCORE: 24

HEALTH FORM: RIPARIAN

FORAGE PRODUCTION (KG/HA)

GRASS $\quad 4300$

TOTAL $\quad 4300$

ECOLOGICALLY SUSTAINABLE STOCKING RATE Generally Non Use

$40.47 \mathrm{ha} / \mathrm{AUM}$

$0.01 \mathrm{AUM} / \mathrm{ac}$ 


\section{DMA2. Marsh reed grass meadow \\ (Calamagrostis canadensis, C. inexpansa, C. stricta)}

$\mathbf{n = 1 2}$ This community is found on the edges of sedge meadows and moist draws where the water table is lower and can be dominated by either species of reed grass. The lower water table makes this community accessible for most of the grazing season. Willow will invade onto these sites to form the Willow/Marsh reed grass community type. Increased grazing pressure on these sites will cause marsh reed grass to decline and their will be an invasion of Kentucky bluegrass and dandelion. These sites are highly productive.

\section{Plant Composition Canopy Cover (\%)}

MEAN RANGE CONST.

\section{SHRUBS}

WILLOW SPP.

(Salix spp.)

FORBS

MINT

(Mentha arvense)

STINGING NeTtLe

(Urtica dioica)

Grasses

MARSH REED GRASS

(Calamagrostis canadensis) 42

BALTIC RUSH

(Juncus balticus)

NORTHERN REED GRASS

(Calamagrostis inexpansa) 1

WATER SEDGE

(Carex aquatilis)

NARROW REED GRASS

(Calamagrostis stricta)

$15 \quad 0-70 \quad 25$

\section{ENVIRONMENTAL VARIABLES}

MOISTURE REGIME (MEAN):

SUBHYGRIC-HYGRIC

Nutrient REgime (MEAN):

RICH

ELEVATION:

603(600-606)M

SoIl Drainage (MEAN):

POORLY

Ecological Status Score: 24

HEALTH FORM: RIPARIAN

\section{FORAGE PRODUCTION(KG/HA)}
Grass
1427(1254-1600)
Forb
812(450-1174)
Total
2237(2050-2424)

ECOLOGICALLY SUSTAINABLE STOCKING RATE

$0.4 \mathrm{ha} / \mathrm{AUM}(0.81-0.34)$

1.0 AUM/ac (0.5-1.2) 


\section{DMA3. Plains wormwood/Sedge (Artemisia campestris/Carex spp.)}

$\mathbf{n = 2}$ This community type is found on coarse textured, sandy soils. It is generally found on hilltops and southfacing slopes in openings among Jack pine on the uplands and black spruce in the lowlands. This community type was also described on similar site conditions in the Central Mixedwood subregion. This community has low forage production and fragile nature.

\section{Plant COMPOSITION Canopy Cover(\%)}

MEAN RANGE CONST.

\section{FORBS}

SCOURING RUSH

(Equisetum hyemale)

PLAINS WORMWOOD

(Artemisia campestris)

LOW GOLDENROD

(Solidago missouriensis)

AMERICAN VETCH

(Vicia americana)

Yellow BEARDSTONGUE

(Penstemon confertus)

\section{Grasses}

KENTUCKY BLUEGRASS

(Poa pratensis)

CREePING RED fESCUE

(Festuca rubra)

SEDGE

(Carex spp)

SHEEP FESCUE

(Festuca saximontana)

$2 \quad 0-4 \quad 50$

$18 \quad 1-34 \quad 100$

$2 \quad 1-3 \quad 100$

\section{ENVIRONMENTAL VARIABLES}

Moisture REgIME (MEAN): XERIC-SUBXERIC

NUTRIENT REGIME (MEAN): SUBMESOTROPHIC

ELEVATION: 467(325-606) M

SoIL DRAINAGE:

RAPIDLY TO WELL

Slope(RANGE): 16(10-22)

Aspect: South to Westerly

Ecological Status Score: 24-16

FORAGE PRODUCTION (KG/HA)

$\begin{array}{ll}\text { GRASS } & 652 \\ \text { FORB } & 525 \\ \text { SHRUB } & 86 \\ \text { TOTAL } & 1263\end{array}$




\section{DMA4. Purple oat grass-Sedge-California oat grass (Schizachne purpurascens-Carex spp.-Danthonia californica)}

$\mathbf{n}=4$ This community appears to be characteristic of dry grassy meadows on dark coloured Solonetzic soils and gentle to level areas throughout the Dry Mixedwood subregion. Wilkinson and Johnson (1982), found there was a close correlation between large tracts of prairie vegetation and the distribution of solonetzic soils in the Peace River district of Alberta. They specifically described Western porcupine grass-Sedge/Fringed sage community on steep south -facing slopes and a Sedge-California oat grass-Western porcupine grass on more gentle slopes. They felt the solonetzic soils supported grasslands and not forests because of their unfavourable ratios of $\mathrm{Ca}$ and $\mathrm{Na}$, hard, columnar B-horizon, and relatively impermeable clay pan close to the surface. This community type appears to more similar to their Sedge-California oat grass-Western porcupine grass community type. It is likely the heavy grazing pressure of the described sites favours the growth of purple oat grass over Western porcupine grass on these sites. Many of the sites described were old homestead sites.

\section{Plant Composition Canopy Cover(\%)}

MEAN RANGE CONST.

\section{SHRUBS}

PRICKLY ROSE

(Rosa acicularis)

SNOWBERRY

(Symphoricarpos

occidentalis)

SASKATOON

(Amelanchier alnifolia)

FORBS

STRAWBERRY

(Fragaria virginiana)

MEADOW RUE

(Thalictrum venulosum)

100DANDELION

(Taraxacum officinale)

YARROW

(Achllea millefolium)

AMERICAN VETCH

(Vicia americana)

\section{Grasses}

PURPLE OAT GRASS

(Schizachne purpurascens)

SLENDER WHEAT GRASS

(Agropyron trachycaulum)

KENTUCKY BLUEGRASS

(Poa pratensis)

PRAIRIE SEDGE

(Carex prairea)

JUNEGRASS

(Koeleria macrantha)
CALIFORNIA OAT GRASS

(Danthonia californica)

$9 \quad 0-28$

50

\section{ENVIRONMENTAL VARIABLES}

Moisture Regime (MeAn): Mesic

Nutrient Regime (MEAN): Medium

ELEVATION: $\quad$ 576-606(584) M

Soil Drainage (MEAN): Well

SLOPE \% (RANGE): $\quad 2(0-5)$

AsPect: SOUth to West

ECOLOGICAL STATUS SCORE: 16

\begin{tabular}{cl} 
FORAGE PRODUCTION (KG/HA) \\
\hline GRASS & $1463(626-2578)$ \\
FORB & $818(500-1192)$ \\
SHRUB & $227(0-606)$ \\
TOTAL & $2508(1600-3316)$
\end{tabular}

ECOLOGICALLY SUSTAINABLE STOCKING RATE

$0.4 \mathrm{ha} / \mathrm{AUM}(0.58-0.31)$

1.0 AUM/ac (0.7-1.3) 


\section{DMA4a. Veiny meadow rue/Slender wheat grass-Fringed brome (Thalictrum venulosum/Agropyron trachycaulum-Bromus ciliatus)}

$\mathbf{n}=\mathbf{2} \quad$ This community appears to be characteristic of dry grassy meadows on dark colored Chernozemic soils and gentle to level areas throughout the Dry Mixedwood subregion. This community type is likely associated with the large tracts of prairie vegetation described by Wilkinson and Johnson (1982) in the Peace River district of Alberta. They specifically described Western porcupine grass-Sedge/Fringed sage community on steep south facing slopes and a Sedge-California oat grass-Western porcupine grass on more gentle slopes. They felt these grasslands were associated with the distribution of solonetzic soils in the Peace River area. This community type appears to be richer than the Sedge-California oat grass-Western porcupine grass community described by Wilkinson and Johnson. The soils on this community are described as Chernozemic and the parent material is fluvial in origin. These sites are very productive.

\section{PLANT COMPOSITION CANopy Cover(\%)}

$$
\text { MEAN RANGE CONST. }
$$

\section{Trees}

WHITE SPRUCE

(Picea glauca)

\section{FORBS}

STRAWBERRY

(Fragaria virginiana)

MEADOW RUE

(Thalictrum venulosum)

FIREWEED

(Epilobium angustifolum)

YARROW

(Achllea millefolium)

TALL LUNG WORT

(Mertensia paniculata)

GraSSES

FRINGED BROME

(Bromus cilatus)

SLENDER WHEAT GRASS

(Agropyron trachycaulum)

WHITE SCALED SEDGE

(Carex xerantica)

MARSH REED GRASS

(Calamagrostis canadensis)

\section{ENVIRONMENTAL VARIABLES}

Moisture Regime (MeAN): Mesic

NUtRIENT REgIME (MEAN): MEDIUM-RICH

ELEVATION: $\quad 472-587(530) \mathrm{M}$

Soll Drainage (MEAN): Moderately WELl

SLOPE: LEVEL

Ecological Status Score: 24

FORAGE PRODUCTION (KG/HA)

Total $2500 *$ ESTIMATE

ECOLOGICALLY SUSTAINABLE STOCKING RATE

$0.4 \mathrm{ha} / \mathrm{AUM}(0.58-0.31)$

$1.0 \mathrm{AUM} / \mathrm{ac}(0.7-1.3)$ 


\section{DMA5. Western porcupine grass-Sedge/Fringed sage (Stipa curtiseta-Carex spp./Artemisia frigida)}

$\mathbf{n = 7}$ This community type is found on steep, south-facing slopes along the banks of the Peace, Smoky and Wapiti rivers throughout the Dry Mixedwood subregion. Wilkinson and Johnson (1982), found there was a close correlation between large tracts of prairie vegetation and the distribution of solonetzic soils in the Peace River district of Alberta. They specifically described Western porcupine grass-Sedge/Fringed sage community on steep south -facing slopes and a Sedge-California oat grass-Western porcupine grass on more gentle slopes. They felt the solonetzic soils supported grasslands and not forests because of their unfavourable ratios of $\mathrm{Ca}$ and $\mathrm{Na}$, hard, columnar B-horizon, and relatively impermeable clay pan close to the surface. Adams (1981), found this community type as being a major source of spring forage for livestock in the Peace River area. He found that with increased grazing pressure sedge, Junegrass, northern and western wheat grass would increase as western porcupine grass declines. Often this community type is on steep slopes and is difficult for domestic livestock to access.

\section{Plant COMPOSITION CANOPY Cover(\%)}

MEAN RANGE CONST.

\section{SHRUBS}

FRINGED SAGE

(Artemisia frigida)

SASKATOON

(Amelanchier alnifolia)

SNOWBERRY

(Symphoricarpos

occidentalis)

\section{FORBS}

LITTLE LEAVED EVERLASTING

\section{(Antennaria parviflora)}

BASTARD'S TOADFLAX

(Commandra umbellata)

PRAIRIE CROCUS

(Anemone patens)

PRICKLY PEAR CACTUS

(Opuntia fragilis)$$
1
$$$$
0-2
$$$$
0-30
$$$$
86
$$$$
71
$$

Grasses

WESTERN PORCUPINE GRASS

(Stipa curtiseta)

BLUNT SEDGE

(Carex obtusata)

GREEN NEEDLEGRASS

(Stipa viridula)

JUNEGRASS

(Koeleria macrantha)

WESTERN WHEAT GRASS

(Agropyron smithii)

\section{KENTUCKY BLUEGRASS}

$\begin{array}{llll}\text { (Poa pratensis) } & 1 & 0-8 & 14\end{array}$

NORTHERN WHEAT GRASS

$\begin{array}{llll}\text { (Agropyron dasystachyum) } & 2 & 0-6 & 29\end{array}$

\section{ENVIRONMENTAL VARIABLES}

\author{
MoISTURE REGIME (MEAN): SUBXERIC-SUBMESIC \\ NUTRIENT REGIME (MEAN): POOR-MEDIUM \\ ELEVATION: 442-606(503) M \\ SoIl Drainage (MEAN): VERY RAPIDLY \\ SLOPE: $\quad 35-82(59) \%$ \\ ASPECT: SOUTH AND WEST \\ ECOLOGICAL STATUS SCORE: 24
}

\section{FORAGE PRODUCTION(KG/HA)}

$\begin{array}{ll}\text { GRASS } & 989(700-945) \\ \text { FORB } & 254(0-531) \\ \text { SHRUB } & 5(0-20) \\ \text { TOTAL } & 1055(752-1476)\end{array}$

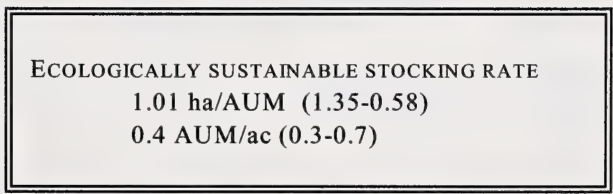




\section{DMA6. Northern wheat grass-Junegrass/Fringed sage (Agropyron dasystachyum-Koeleria macrantha/Artemisia frigida)}

$\mathbf{n = 1 3}$ This community type is found on steep, south-facing slopes along the banks of the Peace, Smoky and Wapiti rivers throughout the Dry Mixedwood subregion. Adams (1981), felt this community type would form when the Western porcupine grass community was heavily to moderately grazed, but a number of plots were described in an area that had little grazing pressure. This community was located on a much steeper slope $(76 \%$ vs $35 \%$ ) than the previously described Western porcupine grass community type. It is likely that the drier site conditions and shallower and poorer nutrient soils favour the growth of northern wheat grass over Western porcupine grass. This community type is located on steep slopes that can be difficult for livestock.

\section{Plant COMPOSITION CANOPY Cover(\%)}

MEAN RANGE CONST.

\begin{tabular}{|c|c|c|c|}
\hline \\
\hline \multicolumn{4}{|l|}{ FRINGED SAGE } \\
\hline (Artemisia frigida) & 6 & $0-20$ & 80 \\
\hline \multicolumn{4}{|l|}{ SASKATOON } \\
\hline (Amelanchier alnifolia) & 6 & $0-15$ & 95 \\
\hline \multicolumn{4}{|l|}{ Rose } \\
\hline (Rosa acicularis) & 3 & $0-15$ & 62 \\
\hline \multicolumn{4}{|l|}{ SNOWBERRY } \\
\hline \multicolumn{4}{|l|}{ (Symphoricarpos } \\
\hline occidentalis) & 3 & $0-10$ & 69 \\
\hline \multicolumn{4}{|l|}{ FORBS } \\
\hline \multicolumn{4}{|l|}{ WILD BLUE FLAX } \\
\hline (Linum lewesii) & 1 & $0-4$ & 23 \\
\hline \multicolumn{4}{|l|}{ LINDLEY'S ASTER } \\
\hline (Aster ciliolatus) & 1 & $0-3$ & 46 \\
\hline SHOWY LOCOWEED & & & \\
\hline (Oxytropis splendens) & 1 & $0-2$ & 39 \\
\hline \multicolumn{4}{|l|}{ DANDELION } \\
\hline (Taraxacum offincinale) & 1 & $0-2$ & 62 \\
\hline \multicolumn{4}{|l|}{ Grasses } \\
\hline \multicolumn{4}{|l|}{ NORTHERN WHEAT GRASS } \\
\hline $\begin{array}{l}\text { (Agropyron dasystachyum) } \\
\text { SEDGE SPP. }\end{array}$ & 10 & $0-17$ & 75 \\
\hline (Carex spp.) & 3 & $0-7$ & 63 \\
\hline \multicolumn{4}{|l|}{ RICHARDSON NEEDLEGRASS } \\
\hline \multicolumn{4}{|l|}{ JUNEGRASS } \\
\hline (Koeleria macrantha) & 5 & $0-20$ & 77 \\
\hline \multicolumn{4}{|l|}{ SLENDER WHEAT GRASS } \\
\hline (Agropyron trachycaulum) & 3 & $0-30$ & 46 \\
\hline
\end{tabular}

\section{ENVIRONMENTAL VARIABLES}

Moisture Regime (MEAN): XERIC-SUBXERIC

NUTRIENT REGIME (MEAN): POOR

ELEVATION: $\quad 345-606 \mathrm{M}$

SoIl Drainage (MEAN): $\quad$ Very RAPIDly

SLOPE: $\quad 68(10-90 \%)$

AsPeCt: $\quad$ South AND WEST

Ecological Status Score: 24-16

\section{FORAGE PRODUCTION (KG/HA)}

$\begin{array}{ll}\text { GRASS } & 600(500-798 \\ \text { FORB } & 183(50-400) \\ \text { SHRUB } & 309(220-450) \\ \text { TOTAL } & 1146(1000-1350)\end{array}$

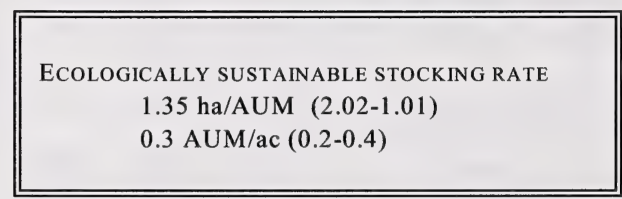




\section{DMA7. Saskatoon-Snowberry/Hairy wild rye (Amelanchier alnifolia-Symphoricarpos occidentalis/Elymus innovatus)}

$\mathbf{n = 9} \quad$ This community represents small shrubby openings within aspen forests on southwest facing slopes and level areas. These sites have well developed Luvisolic soils with colluvial, glacialfluvial and glacial lacustrine parent materials. It is likely these shrubby openings are drier than the surrounding forest, which favours the growth of shrubs over trees. Forage productivity on these sites is only moderate averaging only $677 \mathrm{~kg} / \mathrm{ha}$. These sites are also heavily utilized by wildlife. As a result caution should be used when managing these sites for domestic livestock grazing in order to prevent over-utilization.

\section{Plant COMPOSITION Canopy Cover(\%)}

MEAN RANGE CONST.

\section{SHRUBS}

BLUEBERRY

(Vaccinium myrtilloides)

CHOKECHERRY

(Prunus virginiana)

SNOWBERRY

(Symphoricarpos

occidentalis)

SASKATOON

(Amelanchier alnifolia)

PRICKLY ROSE

(Rosa acicularis)

\section{FORBS}

BEARBERRY

(Arctostaphylos uva-ursi)

STRAWBERRY

(Fragaria virginiana)

YELLOW PEAVINE

(Lathyrus ochroleucus)

LINDLEY'S ASTER

(Aster ciliolatus)

$\begin{array}{lll}1 & 0-5 & 22 \\ 12 & 0-45 & 78 \\ 10 & 1-30 & 100 \\ 15 & 6-65 & 100 \\ 13 & 5-27 & 100\end{array}$

Grasses

NORTHERN RICEGRASS

(Oryzopsis pungens)

SLENDER WHEAT GRASS

(Agropyron trachycaulum)

BLUNT SEDGE

(Carex obtusata)

HAIRY WILD RYE

(Elymus innovatus)

KENTUCKY BLUEGRASS

(Poa pratensis)

\section{ENVIRONMENTAL VARIABLES}

Moisture Regime (MEAN): MESIC-SUBMESIC

NUTRIENT REGIME (MEAN): POOR

ELEVATION: 343-606(460) M

SoIl DRAINAGE (MEAN): VERY RAPIDLY TO WELL SLOPE (RANGE): 17(0-72)

ASPECT:

VARIABLE

ECOLOGICAL STATUS SCORE: 24

\section{Forage Production(KG/Ha)}

$\begin{array}{ll}\text { GRASS } & 344(124-564) \\ \text { FORB } & 189(82-296) \\ \text { SHRUB } & 144(104-184) \\ \text { TOTAL } & 677(524-830)\end{array}$

ECOLOGICALLY SUSTAINABLE STOCKING RATE $2.02 \mathrm{ha} / \mathrm{AUM}(4.05-1.35)$ $0.2 \mathrm{AUM} / \mathrm{ac}(0.1-0.3)$ 


\section{DMA8. Rose-Snowberry/Smooth brome (Rosa acicularis-Symphoricarpos occidentalis/Bromus inermis)}

$\mathbf{n = 2}$ This community type appears to represent the Saskatoon-Snowberry/Hairy wild rye community type which has undergone disturbance by livestock. Sweet clover and smooth brome are both invasive species often originating from roadsides or settlements. Sweet clover is well adapted to growing on roadsides and in waste places. Sweet clover and brome can be very productive but must be used before they become over mature.

\section{Plant COMPOSITION Canopy Cover(\%)}

$$
\text { MEAN RANGE CONST. }
$$

\section{TreEs}

ASPEN

(Populus tremuloides)

$$
5
$$

$$
\text { 4-5 }
$$$$
100
$$

\section{SHRUBS}

SNOWBERRY

(Symphoricarpos

occidentalis)

PRICKLY ROSE

(Rosa acicularis)

SASKATOON

(Amelanchier alnifolia)

\section{FORBS}

STRAWBERRY

$\begin{array}{llll}\text { (Fragaria virginiana) } & 1 & 1-2 & 100\end{array}$

CREAM COLORED VETCHLING(PEAVINE)

$\begin{array}{llll}\text { (Lathyrus ochroleucus) } & 2 & 1-3 & 100\end{array}$

NORTHERN BEDSTRAW

(Galium boreale)

$5 \quad 1-8 \quad 100$

SWEET CLOVER

(Meliolatus officinalis)

$0-16$

Grasses

SMOOTH BROME

(Bromus inermis)

ROSS'S SEDGE

(Carex rossii)

Тімотну

(Phleum pratense)

KENTUCKY BLUEGRASS

(Poa pratensis)

$\begin{array}{lll}7 & 0-13 & 50 \\ 6 & 4-7 & 100 \\ 5 & 0-6 & 50 \\ 1 & 0-1 & 50\end{array}$

\section{ENVIRONMENTAL VARIABLES}

Moisture Regime (MEAN):

SUBMESIC-MESIC

NUTRIENT REGIME (MEAN):

POOR-MEDIUM

ELEVATION:

$455 \mathrm{M}$

SoIl Drainage (MEAN):

WELl TO MODERATELY WELL

SLOPE (RANGE):

$$
4(3-5)
$$

ASPECT:

SOUTHERLY

Ecological Status ScoRe: 8

\section{FORAGE PRODUCTION(KG/HA)}

Total $1500 *$ Estimate

ECOLOGICALLY SUSTAINABLE STOCKING RATE

4.05 ha/AUM (8.09-2.02)

$0.1 \mathrm{AUM} / \mathrm{ac}(0.05-0.2)$ 


\section{DMA9. Kentucky bluegrass/Dandelion \\ (Poa pratensis/Taraxacum officinale)}

$\mathbf{n = 2}$ This community type represents a Marsh reed grass meadow that has undergone heavy prolonged grazing pressure and is now dominated by Kentucky bluegrass, rough hairgrass and dandelion. This community is a fairly productive community type and the species are generally palatable to livestock when grazed in the vegetative state, but the extremely heavy grazing pressure which is needed to displace the native grass species indicates that there are livestock distribution problems that should be addressed.

\section{Plant Composition Canopy Cover(\%)}

\section{ENVIRONMENTAL VARIABLES}

$$
\text { MEAN RANGE CONST. }
$$

\section{FORBS}

AMERICAN VETCH

(Vicia americana)

DANDELION

(Taraxacum officinale)

YELLOW PEAVINE

(Lathyrus ochroleucus)

WILD STRAWBERRY

(Fragaria virginiana)

YARROW

(Achillea millefolium)

HORSETAIL

(Equisetum arvense)

\section{GraSSES}

KENTUCKY BLUEGRASS

(Poa pratensis)

ROUGH HAIRGRASS

(Agrostis scabra)

SLENDER WHEAT GRASS

(Agropyron trachycaulum)

FRINGED BROME

(Bromus ciliatus)

$\begin{array}{lll}3 & 3-4 & 100 \\ 30 & 0-60 & 50 \\ 6 & 0-12 & 50 \\ 7 & 0-14 & 50 \\ 6 & 0-11 & 50 \\ 4 & 0-7 & 50\end{array}$

$\begin{array}{lll}58 & 18-97 & 100 \\ 8 & 0-15 & 50 \\ 3 & 0-5 & 50 \\ 2 & 0-4 & 50\end{array}$

\author{
MoISTURE REGIME (MEAN): \\ HYGRIC-SUBHYGRIC \\ Nutrient REgime (MEAN): \\ $\mathrm{RICH}$ \\ ELEVATION: \\ $697 \mathrm{M}$ \\ SoIL DrainAge (MEAN): \\ IMPERFECTLY \\ Ecological Status Score: 0 or modified \\ FORAGE PRODUCTION(KG/HA)
}

$\begin{array}{ll}\text { GRASS } & 1382 \\ \text { FORB } & 1682 \\ \text { TOTAL } & 3064\end{array}$

ECOLOGICALLY SUSTAINABLE STOCKING RATE

$0.81 \mathrm{ha} / \mathrm{AUM}(1.35-0.4)$

0.5 AUM/ac (0.3-1.0) 


\section{DMA10. Willow/Sedge \\ (Salix spp./Carex spp.)}

$\mathbf{n = 2 7}$ This community type is found along the edges of sedge meadows and in moist depressions. Generally flat leaved willow and basket willow become established at the edges of the sedge meadows due to the shorter duration of standing water. Increased flooding and prolonged water logging may result in the disappearance of willow and a transition to a water sedge meadow.

These sites are fairly productive but difficult to graze due to the moist ground conditions and heavy shrub cover which reduces access and mobility within the area.

\section{Plant COMPOSITION Canopy Cover(\%)}

$$
\text { MEAN RANGE CONST. }
$$

\section{SHRUBS}

BEBB WILLOW

(Salix bebbiana)

FLAT LEAVED WILLOW

(Salix planifolia)

BASKET WILLOW

(Salix petiolaris)$$
0-65
$$$$
11
$$

$$
0-90
$$$$
7
$$$$
0-60
$$

\section{FORBS}

MINT

(Mentha arvensis)

SKULLCAP

(Scutellaria galericulata)

STRAWBERRY

$\begin{array}{llll}\text { (Fragaria virginiana) } & 2 & 0-18 & 29\end{array}$

DANDELION

1

$0-5$
(Taraxacum officinale)

ARRowed LEAVEd COLTSFOoT

(Petasites sagittatus)

2

\section{GRASSES}

AWNED SEDGE

(Carex atherodes)

$\begin{array}{lll}12 & 0-70 & 59 \\ 2 & 0-11 & 48 \\ 11 & 1-42 & 70 \\ 9 & 0-80 & 63\end{array}$

$0-22 \quad 30$

$2 \quad 0-30 \quad 41$

MARSH REED GRASS

(Calamagrostis canadensis)

BEAKED SEDGE

(Carex rostrata)

WATER SEDGE

(Carex aquatilis)

\section{ENVIRONMENTAL VARIABLES}

MoIsture REgIME (MEAN): SUBHYDRIC

Nutrient REgime (MEAN): $\mathrm{RICH}$

ELEVATION: 576-606(588) M

SoIL DRAINAGE (MEAN): POORLY

Ecological Status Score: 24

HEALTH FORM: RIPARIAN

\section{FORAGE PRODUCTION(KG/HA)}

$\begin{array}{ll}\text { GRASS } & 673(344-1002) \\ \text { FORB } & 470(52-888) \\ \text { SHRUB } & 11(0-22) \\ \text { TOTAL } & 1169(448-1890)\end{array}$

ECOLOGICALLY SUSTAINABLE STOCKING RATE $0.81 \mathrm{ha} / \mathrm{AUM}(40.47-0.4)$ $0.5 \mathrm{AUM} / \mathrm{ac}$ (0.01-1.0) 


\section{DMA10a. Willow/Marsh reed grass \\ (Salix spp./Calamagrostis canadensis)}

$\mathbf{n = 1 8}$ This community type is found along the edges of sedge and marsh reed grass meadows and in moist depressions. Predominantly flat leaved willow becomes established at the edges of these meadows due to the shorter duration of standing water. Increased flooding and prolonged water logging may result in the disappearance of willow and a transition to a marsh reed grass and water sedge meadow. These sites are fairly productive but difficult to graze due to the moist ground conditions and heavy shrub cover which reduces access and mobility within the area.

\section{Plant Composition Canopy Cover(\%)}

MEAN RANGE CONST,

SHRUBS

BEBB WILLOW

(Salix bebbiana)

FLAT LEAVED WILlow

(Salix planifolia)

BASKET WILLOW

(Salix petiolaris)

ForbS

SKULLCAP

(Scutellaria galericulata)

MARSH HEMP NETTLE

(Stachys palustris)

STRAWBERRY

(Fragaria virginiana)

STINGING NETTLE

(Urtica dioica)

HORSETAIL

(Equisetum arvense)

$0-20$

44

26

0-70

75

3

$0-20$

38

\section{Grasses}

AWNED SEDGE

(Carex atherodes)

2

MARSH REED GRASS

(Calamagrostis canadensis)

BEAKED SEDGE

(Carex rostrata)

Fow L BLUEGRASS

(Poa palustris)

\section{ENVIRONMENTAL VARIABLES}

MoISTURE REgIME (MEAN): SUBHYDRIC

NUTRIENT REGIME (MEAN): RICH

ELEVATION:

$606 \mathrm{M}$

SoIl Drainage (MEAN): POORLY

Ecological Status Score: 24

HEALTH FORM: RIPARIAN

\section{FORAGE PRODUCTION(KG/HA)}

$\begin{array}{ll}\text { GRASS } & 1325(900-1750) \\ \text { FORB } & 75(50-200) \\ \text { TOTAL } & 1400(950-1850)\end{array}$

ECOLOGICALLY SUSTAINABLE STOCKING RATE $0.81 \mathrm{ha} / \mathrm{AUM}(40.47-0.4)$

$0.5 \mathrm{AUM} / \mathrm{ac}$ (0.01-1.0) 


\section{DMA11. Willow/Marsh reed grass-Kentucky bluegrass \\ (Salix spp./Calamagrostis canadensis-Poa pratensis)}

$\mathbf{n}=\mathbf{6}$ This community type is very similar to the Willow/Marsh reed grass community type, but has been heavily grazed favouring the growth of Kentucky bluegrass and dandelion. Continued heavy grazing pressure will eventually lead to a understory community that is similar to the Willow/Kentucky bluegrass/dandelion dominated community type.

\section{Plant COMPOSITION Canopy Cover $(\%)$}

$$
\text { MeAn RANGe CONST. }
$$

\section{SHRUBS}

W ILLOW SPP.

(Salix spp.)

SNOWBERRY

(Symphoricarpos

occidentalis)

FORBS

MINT

(Mentha arvensis)

DANDELION

(Taraxacum offincinale)

BUSHY CINQUEFOIL

(Potentilla paradoxa)

\section{GraSSES}

MARSH REED GRASS

(Calamagrostis canadensis)

KENTUCKY BLUEGRASS

(Poa pratensis)

BALTIC RUSH

(Juncus balticus)

FOXTAIL BARLEY

(Hordeum jubatum)

$\begin{array}{lll}17 & 10-35 & 100 \\ 1 & 0-1 & 17\end{array}$

$2 \quad 0-6 \quad 83$

$15 \quad 1-41 \quad 100$

$1 \quad 0-2 \quad 67$

67

$\begin{array}{lll}15 & 3-42 & 100 \\ 17 & 4-32 & 100 \\ 2 & 0-9 & 17 \\ 1 & 0-3 & 83\end{array}$

\section{ENVIRONMENTAL VARIABLES}

Moisture REgIME (MEAN):

SUBHYGRIC

Nutrient REgime (MEAN):

$$
\text { RICH }
$$

ELEVATION:

600-606 M

SOIL DRAINAGE (MEAN):

$$
\text { IMPERFECTLY }
$$

ECOlOgical Status Score: $16-8$

HEALTH FORM: RIPARIAN

\section{FORAGE PRODUCTION(KG/HA)}

$\begin{array}{ll}\text { GRASS } & 1861(1800-1922) \\ \text { FORB } & 621(176-2450) \\ \text { SHRUB } & 5(0-28) \\ \text { TOTAL } & 2487(1800-4250)\end{array}$

ECOLOGICALLY SUSTAINABLE STOCKING RATE $1.01 \mathrm{ha} / \mathrm{AUM}(2.02-0.5)$

$0.4 \mathrm{AUM} / \mathrm{ac}(0.2-0.8)$ 


\section{DMA12. Willow/Horsetail/Marsh reed grass \\ (Salix spp./Equisetum arvensis/Calamagrostis canadensis)}

$\mathbf{n = 1 2}$ This community type appears to be transitional between the horsetail (hygric/rich) and shrubby rich fen (subhydric/rich) ecosites described by Beckingham and Archibald (1996). It has plant species characteristic of both ecosites. This community type is also similar to the Willow-Alder/Fern community described on moist, nutrient rich seepage areas in the Lower Foothills subregion (Lane et al. 2000). This community type is very productive, but the high shrub cover and slope conditions make it difficult to graze. Horsetail the principal forage species is generally unpalatable to domestic livestock and can be poisonous to livestock in large amounts (Lodge et al. 1968).

\section{Plant COMPOSITION CANOPY Cover(\%)}

MEAN RANGE CONST.

\section{SHRUBS}

SCOULER'S WILLOW

(Salix scouleriana)

WILlOW SPP.

(Salix spp.)

BRACTED HONEYSUCKLE

(Lonicera involcrata)

RED OSIER DOGWOOD

(Cornus stolonifera)

\section{FORBS}

StingING NetTle

(Urtica dioica)

COMMON HORSETAIL

(Equisetum arvensis)

LARGE LEAVED YELLOW AVENS

(Geum macrophyllum) 1

DEWBERRY

(Rubus pubescens)

\section{2}

Grasses

MARSH REED GRASS

(Calamagrostis canadensis)

$0-3 \quad 58$

$0-10 \quad 67$

\section{ENVIRONMENTAL VARIABLES}

MoISTURE Regime (MEAN):

SUBHYGRIC

Nutrient REgIME (MEAN):

PERMESOTROPHIC

ElEVATION:

$667 \mathrm{M}$

SoIl DRAINAGE (MEAN):

MODERATELY WELL

Ecological Status Score: 24

HEALTH FORM: RIPARIAN

FORAGE PRODUCTION(KG/HA)

$\begin{array}{ll}\text { GRASS } & 580 \\ \text { FORB } & 1272 \\ \text { TOTAL } & 1852\end{array}$

TOTAL 1852

ECOLOGICALLY SUSTAINABLE STOCKING RATE

$2.02 \mathrm{ha} / \mathrm{AUM}$ (40.47-1.35)

0.2 AUM/ac (0.01-0.3) 


\section{DMA13. River alder/Horsetail \\ (Alnus tenuifolia/Equisetum arvensis)}

$\mathbf{n = 6}$ This community represents lowland sites surrounding open water or nutrient rich river flood plains This community is part of the red osier dogwood ecological site. Succession in the absence of disturbance will likely be to balsam poplar and eventually white spruce. The high shrub cover limits access to livestock.

\section{Plant Composition Canopy Cover(\%)}

Mean RANGe CONST.

TREES

PAPER BIRCH

(Betula papyrifera)

LARCH

(Larix laricina)

\section{SHRUBS}

WILLOW SPP.

(Salix spp.)

RIVER ALDER

(Alnus tenuifolia)

BRACTED HONEYSUCKLE

(Lonicera involcrata)

RED OSIER DOGWOOD

(Cornus stolonifera)

\section{FORBS}

DEWBERRY

(Rubus pubescens)

BISHOP's CAP

(Mitella nuda)

HORSETAIL

(Equisetum arvensis)

HEMP NETTLE

(Galeopsis tetrahit)

$\begin{array}{lll}4 & 0-25 & 33 \\ 1 & 0-5 & 17\end{array}$

$2 \quad 1-3 \quad 100$

$43 \quad 10-90 \quad 100$

$2 \quad 0-7 \quad 33$

$1 \quad 0-3 \quad 50$

Grasses

SEDGE

(Carex spp.)

MARSH REED GRASS

$\begin{array}{llll}\text { (Calamagrostis canadensis) } & 5 & 0-10 & 83\end{array}$

NODDING WOOD REED

(Cinna latifolia)

SMOOTH BROME

(Bromus inermis)
$8 \quad 0-30 \quad 67$

$2 \quad 0-5 \quad 50$

$\begin{array}{lll}6 & 0-27 & 67\end{array}$

$9 \quad 0-50 \quad 33$

$3 \quad 0-20 \quad 33$

$\begin{array}{lll}8 & 0-50 \quad 17\end{array}$

\section{ENVIRONMENTAL VARIABLES}

MOISTURE REgIME (MEAN):

HYGRIC

Nutrient REgIME (MEAN):

RICH

ELEVATION:

$606 \mathrm{M}$

SoIL DRAINAGE (MEAN): IMPERFECTLY

Ecological Status Score: 24

HEALTH FORM: RIPARIAN

\section{FORAGE PRODUCTION(KG/HA)}

$\begin{array}{ll}\text { GRASS } & 102 \\ \text { FORB } & 330 \\ \text { SHRUB } & 104 \\ \text { TOTAL } & 536\end{array}$

ECOLOGICALLY SUSTAINABLE STOCKING RATE 8.09 ha/AUM (40.47-8.09)

0.05 AUM/ac (0.01-0.05) 


\section{DMA14. Willow/Kentucky bluegrass/Dandelion (Salix spp./Poa pratensis/Taraxacum officinale)}

$\mathbf{n = 7}$ This community type is very similar to the Willow/ Marsh reed grass community type, but has been heavily grazed favouring the growth of Kentucky bluegrass and dandelion. Continued heavy grazing pressure eventually leads to a understory community that is dominated by Kentucky bluegrass and dandelion.

\section{Plant COMPOSITION Canopy Cover(\%)}

MEAN RANGE CONST.

\section{SHRUBS}

WILLOW SPP.

(Salix spp.)

SCOULER's WILLOW

(Salix scouleriana)

FLAT LEAVED WILLOW

(Salix planifolia)

FORBS

MINT

(Mentha arvensis)

DANDELION

(Taraxacum officinale)

Plantain

(Plantago major)

STRAWBERRY

(Fragaria virginiana)

\section{Grasses}

MARSH REED GRASS

(Calamagrostis canadensis)

KENTUCKY BLUEGRASS

(Poa pratensis)

FOWL BLUEGRASS

(Poa palustris)

SMOOTH BROME

(Bromus inermis)

$\begin{array}{lll}8 & 0-20 & 85 \\ 9 & 0-50 & 29 \\ 11 & 0-40 & 29\end{array}$

$11 \quad 0-40 \quad 29$

$2 \quad 0-10 \quad 57$

$32 \quad 0-80 \quad 71$

$1 \quad 0-5 \quad 21$

$2 \quad 0-10 \quad 57$

$5 \quad 0-10 \quad 86$

$10 \quad 0-40 \quad 43$

$4 \quad 0-10 \quad 71$

$4 \quad 0-30 \quad 14$

\section{ENVIRONMENTAL VARIABLES}

Moisture Regime (MEAN):

SUBHYGRIC

NUTRIENT REGIME (MEAN):

$\mathrm{RICH}$

ELEVATION:

$600-606 \mathrm{M}$

Soll Drainage (MEAN):

IMPERFECTLY

ECOlogical Status Score: 8

HEALTH FORM: RIPARIAN

\section{FORAGE PRODUCTION(KG/HA)}
GRASS
$1100(700-1500)$
FORB
$1250(750-1750$
TOTAL 2350(2250-2450)

ECOLOGICALLY SUSTAINABLE STOCKING RATE

$1.35 \mathrm{ha} / \mathrm{AUM}$ (40.47-0.67)

$0.3 \mathrm{AUM} / \mathrm{ac}$ (0.01-0.6) 


\section{DMA15. Sandbar willow-Yellow willow (Salix exigua-Salix lutea)}

$\mathbf{n = 1 4}$ This community type occurs on moist alluvial deposits which are adjacent to streams and rivers. This community can persist for some time if the site is subject to frequent flooding. However in the absence of disturbance it will eventually undergo succession to a spruce dominated community type. Thompson and Hansen (2002) described this community in the grassland natural region of Southern Alberta. They found that this community type disappeared as one moved north into the Parkland and it was replaced by basket willow and flat leaved willow dominated community types. Typically there is little understory vegetation found in this community type and it should be rated as non-use for livestock.

\section{PLANT COMPOSITION CANOPY COVER (\%)}

MEAN RANGE CONST.

\section{Trees}

BALSAM POPLAR

(Populus balsamifera)

\section{SHRUBS}

SANDBAR WILLOW

(Salix exigua)

YELLOW WILLOW

(Salix lutea)

SHINING WILlow

(Salix lucida)

\section{FORBS}

HORSETAIL

(Equisetum arvense)

SILVERWEED

(Potentilla anserina)

Plantain

(Plantago major)

\section{GraSSES}

SMALL FRUITED BULRUSH (Scirpus microcarpus)

KENTUCKY BLUEGRASS

(Poa pratensis)

SMOOTH BROME

(Bromus inermis)

$\begin{array}{lll}12 & 0-90 & 64 \\ 2 & 0-10 & 43 \\ 2 & 0-20 & 29\end{array}$

$2 \quad 0-10 \quad 43$

$2 \quad 0-3 \quad 50$

$9 \quad 0-90 \quad 57$

\section{ENVIRONMENTAL VARIABLES}

MoISTURE REGIME: HYGRIC

NUTRIENT REGIME: RICH

Elevation: $600 \mathrm{M}$

SOIL DRAINAGE: IMPERFECTLY

Ecological Status Score: 24

HEALTH FORM: RIPARIAN

FORAGE PRODUCTION(KG/HA)

TOTAL $\quad 1000 *$ ESTIMATE

ECOLOGICALLY SUSTAINABLE STOCKING RATE Generally Non Use

$40.47 \mathrm{ha} / \mathrm{AUM}$

$0.01 \mathrm{AUM} / \mathrm{ac}$ 


\section{DMA16: Bebb willow/Marsh reed grass \\ (Salix bebbiana/Calamagrostis canadensis)}

$\mathbf{n}=13$ This community type is found along the drier edges of marsh reed grass meadows and in moist depressions and represents the transition between the flat leaved willow and basket willow dominated shrublands and the upland forest. Bebb willow is an upland species that prefers well drained sites. This species of willow is often found in the understory of aspen and balsam poplar dominated community types. Increased flooding and prolonged water logging may result in the disappearance of Bebb willow and favour the growth of flat leaved willow. In contrast the continued drying of the site will favour the growth of balsam poplar. These sites are fairly productive but difficult to graze due to the moist ground conditions and heavy shrub cover which reduces access and mobility within the area.

\section{PLANT COMPOSITION CANOPY COVER (\%)} MEAN RANGE CONST.

\section{TreEs}

BALSAM POPLAR

(Populus balsamifera)

2

$0-10$

23

SHRUBS

BEBB WILLOW

(Salix bebbiana)

SNOWBERRY

(Symphoricarpos

occidentalis)

RASPBERRY

(Rubus idaeus)

Rose

(Rosa acicularis)

\section{FORBS}

HorseTAIL

(Equisetum arvense)

DANDELION

(Taraxacum officinale)

STRAWBERRY

(Fragaria virginiana)

CANADA GoldenRoD

(Solidago canadensis)

\section{GRASSES}

KENTUCKY BLUE GRASS

(Poa pratensis)

SMOOTH BROME

(Bromus inermis)

SEDGE

(Carex spp.)

MARSH REED GRASS

(Calamagrostis

canadensis)

\section{ENVIRONMENTAL VARIABLES}

MOISTURE REGIME: SUBHYGRIC-HYGRIC

NUTRIENT REGIME: RICH

ELEVATION(MEAN): $600 \mathrm{M}$

SOIL DRAINAGE: MOD. WELL

Ecological Status Score: 24

HEALTH FORM: RIPARIAN

\section{Forage Production (KG/HA)}

TOTAL

$1500 *$ ESTIMATE

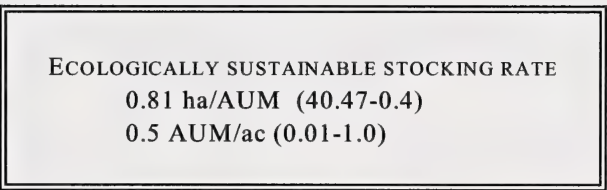




\section{DMA17: Red osier dogwood/Marsh reed grass \\ (Cornus stolonifera/Calamagrostis canadensis)}

$\mathbf{n}=\mathbf{8}$ This community type was described on alluvial terraces, streambanks, abandoned channels on river floodplains and moist areas around springs and seeps. This community is much richer and has higher moisture levels than the adjacent upland aspen dominated forest, but it is much drier than the willow dominated shrublands in lower slope positions. In the absence of disturbance this community type will likely succeed to a balsam poplar and eventually white spruce dominated community type.

Livestock generally do not prefer this community type because of the dense nature of the understory, but heavy grazing pressure can reduce the understory cover and allow Kentucky bluegrass, timothy and smooth brome to invade.

\section{PLANT COMPOSITION CANOPY COVER (\%)}

MEAN RANGE CONST.

TREES

BALSAM POPLAR

(Populus balsamifera)

$1 \quad 0-3 \quad 50$

\section{Shrubs}

RED OSIER DOGWOOD

(Cornus stolonifera)

Rose

(Rosa acicularis)

SNOWBERRY

(Symphoricarpos

occidentalis)

RASPBERRY

(Rubus idaeus)

FORBS

VEINY MEADOW RUE

(Thalictrum venulosum)

HORSETAIL

(Equisetum arvense)

AMERICAN VETCH

(Vicia americana)

$\begin{array}{lll}50 & 20-90 & 100 \\ 3 & 0-10 & 75 \\ 5 & 0-20 & 50 \\ 5 & 0-30 & 50\end{array}$

\section{GRASSES}

MARSH REED GRASS

(Calamagrostis canadensis)

FOWL BLUEGRASS

(Poa palustris)

\section{ENVIRONMENTAL VARIABLES}

MOISTURE REGIME: SUBHYGRIC

NUTRIENT REGIME: RICH

ELEVATION(MEAN): $600 \mathrm{M}$

SOIL DRAINAGE: MOD. WELL

ECOLOGICAL STATUS SCORE: 24

HEALTH FORM: RIPARIAN

Forage Production (KG/Ha)

TOTAL $1500 *$ ESTIMATED

ECOLOGICALLY SUSTAINABLE STOCKING RATE

$0.81 \mathrm{ha} / \mathrm{AUM}(2.02-0.4)$

0.5 AUM/ac (0.2-1.0) 


\section{DMA18: Silverberry/Smooth brome (Elaeagnus commutata/Bromus inermis)}

$\mathbf{n}=\mathbf{2}$ This community type has similar moisture and nutrient conditions to the previously described red osier dogwood dominated community type. Silverberry prefers moist, well drained seepage areas where overland flow provides additional moisture. This species can be found adjacent to streams and rivers, or seepage areas and snow accumulation areas adjacent to aspen stands. Thompson and Hansen (2002) found that these silverberry shrublands are often associated with disturbance in the grassland natural region of southern Alberta. Indeed, smooth brome is dominate in the understory of this community and it has likey invaded off the road allowance adjacent to this site. This community type is very productive because of the favourable moisture conditions, but as succession occurs to an aspen forest many of the palatable grass and forbs are often lost. This community will likely succeed to an $\mathrm{Pb} /$ Snowberry/Smooth brome dominated community type.

\section{Plant Composition canopy cover (\%)}

TREES

BALSAM POPLAR

(Populus balsamifera)

MEAN RANGE CONST.

SHRUBS

PRAIRIE ROSE

(Rosa arkansana)

SNOWBERRY

(Symphoricarpos

occidentalis)

SILVERBERRY

(Elaeagnus commutata)

FORBS

Stinging netTle

(Urtica dioica)

STRAWBERRY

(Fragaria virginiana)

YARROW

(Achillea millefolium)

\section{GRASSES}

KENTUCKY BLUE GRASS

(Poa pratensis)

SMOOTH BROME

(Bromus inermis)

QUACKGRASS

(Agropyron repens.)

$2 \quad 0-3 \quad 50$

$5 \quad 0-10 \quad 50$

$12 \quad 3-20 \quad 100$

$2 \quad 1-3 \quad 100$

\section{ENVIRONMENTAL VARIABLES}

MOISTURE REGIME: SUBHYGRIC-MESIC

NUTRIENT REGIME: RICH

ELEVATION(MEAN): $600 \mathrm{M}$

SOIL DRAINAGE: WELL

ECOLOGICAL STATUS SCORE: $8-0$

\section{Forage Production (Kg/Ha)}

TOTAL

$1500 *$ ESTIMATE

ECOLOGICALLY SUSTAINABLE STOCKING RATE $1.35 \mathrm{ha} / \mathrm{AUM}(2.02-0.67)$

$0.3 \mathrm{AUM} / \mathrm{ac}(0.2-0.6)$ 


\section{DMA19: Bog willow \\ (Salix pedicellaris)}

$\mathbf{n}=4$ This community type was described on floating fens in the northern part of the Dry Mixedwood subregion near Gunn and Tulliby lake. Bog willow tends to prefer growing in swamps and fens throughout the Boreal forest of Northern Alberta (Johnson et al. 1995). The slight acidity on these sites limits productivity and these site are difficult to graze due to the moist ground conditions and heavy shrub cover which reduces access and mobility within the area.

\section{PLANT COMPOSITION CANOPY COVER (\%)}

$$
\text { MEAN RANGE CONST. }
$$

TreEs

PAPER BIRCH

(Betula papyrifera)

1

$0-1$

50

\section{SHRUBS}

BOG WILLOW

(Salix pedicellaris)

\section{FORBS}

MARSH CINQUEFOIL

(Potentilla palustre)

SKULlCAP

(Scutellaria galericulata)

$1-20$

100

\section{GRASSES}

TWO STAMENED SEDGE

(Carex diandra)

WATER SEDGE

(Carex aquatilis)

NARROW REED GRASS

(Calamagrostis stricta)

\section{ENVIRONMENTAL VARIABLES}

MOISTURE REGIME: SUBHYDRIC

NUTRIENT REGIME: MEDIUM

ELEVATION(MEAN): 600M

SOIL DRAINAGE: IMPERFECTLY

ECOLOGICAL STATUS SCORE: 24

HEALTH FORM: RIPARIAN

\section{Forage Production (KG/Ha)}

TOTAL $\quad 1500 *$ Estimate

\begin{tabular}{|c||}
\hline ECOLOGICALLY SUSTAINABLE STOCKING RATE \\
Generally Non Use \\
$40.47 \mathrm{ha} / \mathrm{AUM}$ \\
$0.01 \mathrm{AUM} / \mathrm{ac}$ \\
\hline
\end{tabular}




\section{DMA20. Swamp horsetail (Equisetum fluviatile)}

$\mathbf{n = 3}$ This wetland community type is found near fresh water and is often associated with shallow water around lake shores or saturated wet spots in old river channels and sloughs. This community is often only found in small isolated spots or in narrow bands around the edge of lakes. As these areas dry, swamp horsetail is often replaced by sedge species. Swamp horsetail is generally unpalatable to livestock and the areas it grows in are often to wet for livestock to access.

\section{Plant Composition Canopy Cover(\%)}

\section{MEAN RANGE CONST.}

\section{FORBS}

SWAMP HORSETAIL

(Equisetum fluviatile)

MARSH WILLOW HERB

(Epilobium leptophyllum)

SKULl CAP

(Scutellaria galericulata)

SMALL BEDSTRAW

(Galium trifidum)

\section{Grasses}

BEAKED SEDGE

(Carex rostrata)

W ATER SEDGE

(Carex aquatilis)

CATTAIL

(Typha latifolia)

$\begin{array}{lll}77 & 50-90 & 100 \\ 13 & 0-40 & 33 \\ 3 & 0-10 & 33 \\ 7 & 0-20 & 33\end{array}$

3

0-10

33

8

$0-20$

66

1

$0-1$

33

\section{ENVIRONMENTAL VARIABLES}

\author{
Moisture RegIME (MEAN): \\ SUBHYDRIC-HYGRIC \\ NUTRIENT REgIME (MEAN): \\ RICH \\ ELEVATION: \\ 586(579-600) M \\ SOIL DRAINAGE (MEAN): \\ POORLY TO VERY POORLY \\ ECOLOGICAL STATUS SCORE: 24 \\ HEALTH FORM: RIPARIAN
}

\section{FORAGE PRODUCTION (KG/HA)}

Total $2000 *$ Estimate

ECOLOGICALLY SUSTAINABLE STOCKING RATE

Generally Non Use

$40.47 \mathrm{ha} / \mathrm{AUM}$

$0.01 \mathrm{AUM} / \mathrm{ac}$ 


\section{DMA21. Tall manna grass \\ (Glyceria grandis)}

$\mathbf{n = 3}$ This wetland community type is associated with the edge of the standing water of ponds, sloughs and slow meandering streams. As one moves away from the water to the drier edges the sedge meadow communities are found. This community is often only found in small isolated spots or in narrow bands around the edge of lakes. As these areas dry, tall manna grass is often replaced by sedge species. Tall manna grass is palatable to livestock, however, the areas it grows in are often to wet for livestock to access.

\section{Plant COMPOSITION Canopy Cover(\%)}

MEAN RANGE CONST.

\section{FORBS}

SWAMP HORSETAIL

(Equisetum fluviatile)

MARSH WILLOWHERB

(Epilobium leptophyllum)

SMALL BEDSTRAW

(Galium trifidum)

\section{GrasSES}

TALL MANNA GRASS

(Glyceria grandis)

AWNED SEDGE

(Carex atherodes)

CATTAIL

(Typha latifolia)

\section{ENVIRONMENTAL VARIABLES}

Moisture REgIME (MEAN):

SUBHYDRIC-HYGRIC

NUTRIENT REgIME (MEAN

PERMESOTROPHIC

Elevation:

$606 \mathrm{M}$

SoIl DRAINAGE (MEAN):

VERY POORLY

ECOLOGICAL STATUS SCORE: 24

HEALTH FORM: RIPARIAN

FORAGE PRODUCTION (KG/HA)

GRASS $\quad 2000$

TOTAL $2000 *$ ESTIMATE

ECOLOGICALLY SUSTAINABLE STOCKING RATE

$0.54 \mathrm{ha} / \mathrm{AUM}$

$0.75 \mathrm{AUM} / \mathrm{ac}$ 


\section{DMA22. Common reed grass \\ (Phragmites australis)}

$\mathbf{n}=\mathbf{3}$ This community is found on the edges of shallow lakes and sloughs where the water table is near the surface for most of the growing season. Common reed grass is common throughout the Boreal forest and this species is very important in binding the soil on river banks. The high sugar content of this plant makes it very palatable to livestock, but the moist ground conditions limits livestock use of these areas.

\section{Plant CoMposition Canopy Cover(\%)}

$$
\text { MEAN RANGE CONST. }
$$

\section{SHRUBS}

WILLOW SPP.

(Salix spp.)

$2 \quad 0-5 \quad 33$

\section{Forbs}

MINT

(Mentha arvense)

SKullcaP

(Scutellaria galericulata)

$\begin{array}{lll}1 & 0-1 & 66 \\ 1 & 0-1 & 66\end{array}$

Grasses

MARSH REED GRASS

(Calamagrostis canadensis)

COMMON REED GRASS

(Phragmites australis)

AWNED SEDGE

(Carex atherodes)

CREEPING SPIKE RUSH

(Eleocharis palustris)

\section{ENVIRONMENTAL VARIABLES}

MoISTURE REgIME (MEAN):

SUBHYDRIC

NUTRIENT REGIME (MEAN):

PERMESOTROPHIC

ELEVATION:

603(600-606)M

SoIL DRAINAGE (MEAN):

POORLY

ECOLOGICAL STATUS SCORE: 24

HEALTH FORM: RIPARIAN

\section{FORAGE PRODUCTION(KG/HA)}

Total 2000*Estimate

ECOLOGICALLY SUSTAINABLE STOCKING RATE

Generally Non Use

$40.47 \mathrm{ha} / \mathrm{AUM}$

$0.01 \mathrm{AUM} / \mathrm{ac}$ 


\section{DMA23. Reed canary grass (Phalaris arundinacea.)}

$\mathbf{n = 1}$ This community type is found along the edges of lakes, rivers, streams and pond margins. The European variety of this species has been widely distributed as a forage and often escapes from pastures and invades into the riparian and wetland areas, displacing more desirable species (Thompson and Hansen 2002). Once this species has invaded riparian areas it often forms monospecific stands because of its heavy sod forming habit (Thompson and Hansen 2002). Reed canary grass is moderately palatable to livestock and when it is grazed heavily the site often becomes invaded by thistle, dandelion and Kentucky bluegrass.

\section{Plant Composition Canopy Cover $(\%)$}

MEAN RANGE CONST.

\section{FORBS}

CANADA THISTLE

(Cirsium arvense)

WATER SMARTWEED

(Polygonum amphibium)

SOW THISTLE

(Sonchus spp.)

MARSH HEDGE-NETTLE

(Stachys palustris)

\section{GraSSES}

REDTOP

(Agrostis stolonifera)

REED CANARY GRASS

(Phalaris arundinacea)

SLENDER WHEAT GRASS

(Agropyron trachycaulum)

100

\section{ENVIRONMENTAL VARIABLES}

MOISTURE REGIME (MEAN):

SUBHYDRIC

Nutrient Regime (MEAN):

PERMESOTROPHIC

ELEVATION:

$600 \mathrm{M}$

Soil Drainage:

POORLY

ECOLOGICAL STATUS SCORE: 24

HEALTH FORM: RIPARIAN

FORAGE PRODUCTION (KG/HA)
Total $2000^{*}$ ESTIMATE

ECOLOGICALLY SUSTAINABLE STOCKING RATE

$$
\begin{gathered}
0.81 \mathrm{ha} / \mathrm{AUM} \\
0.5 \mathrm{AUM} / \mathrm{ac}
\end{gathered}
$$




\section{DMA24. Two stamened sedge \\ (Carex diandra)}

$\mathbf{n}=\mathbf{5}$ This community type was described in boggy areas adjacent to black spruce and larch dominated community types. Two stamened sedge tends to be found in the wetter areas where there is a floating mat of peat. As these areas dry out two stamened sedge will be replaced by willow, black spruce and larch species. Two stamened sedge is generally unpalatable to livestock and the areas it grows in are often too wet for livestock to access.

\section{PLANT COMPOSITION CANOPY Cover(\%)}

MEAN RANGE CONST.

\section{SHRUBS}

Bog WILLOW

(Salix pedicellaris)

BOG BIRCH

(Betula glandulosa)

$$
0-30
$$$$
40
$$$$
1
$$$$
0-3
$$$$
40
$$

\section{FORBS}

BUCK-BEAN

(Menyanthes trifoliata)

MARSH CINQUEFOIL

(Potentilla palustris)

MARSH MARIGOLD

(Caltha palustris)

\section{Grasses}

TWO STAMENED SEDGE

(Carex diandra)

WATER SEDGE

(Carex aquatilis)

$82 \quad 60-90 \quad 100$

$1 \quad 0-3 \quad 40$

\section{ENVIRONMENTAL VARIABLES}

MoISTURE REgIME (MEAN):

SUBHYDRIC

NUTRIENT REGIME (MEAN):

MESOTROPHIC

Elevation:

576-606(584) M

SoIl DRAINAGE (MEAN):

WELL

Ecological Status Score: 24

HEALTH FORM: RIPARIAN

\section{FORAGE PRODUCTION (KG/HA)}

Total $1500 *$ ESTIMATE

ECOLOGICALLY SUSTAINABLE STOCKING RATE

Generally Non Use

$40.47 \mathrm{ha} / \mathrm{AUM}$

$0.01 \mathrm{AUM} / \mathrm{ac}$ 


\section{DMA25. Rush meadow \\ (Juncus balticus, J. nodosus)}

$\mathbf{n = 2}$ This community type was described on slightly saline sandy lakeshores. As the lake recedes rush species will invade into the sand of the lakeshore. Bailey et al. (1992) described rush dominated meadows in a saline sequence in the Yukon and Thompson and Hansen (2002) felt that rush dominated meadows were indicative of heavy grazing pressure in Southern Alberta. Rush species are generally unpalatable to livestock.

\section{Plant COMPosition Canopy Cover(\%)}

MEAN RANGE CONST.

\section{Trees}

BALSAM POPLAR

(Populus balsamifera)

FORBS

PRICKLY SOW THISTLE

(Sonchus asper)

Grasses

BALTIC RUSH

(Juncus balticus)

KNOTTED RUSH

(Juncus nodosus)

\section{ENVIRONMENTAL VARIABLES}

MoIstuRe Regime (MEAN):

SUBHYGRIC

Nutrient Regime (MEAN):

SUBMESOTROPHIC

Elevation:

$600 \mathrm{M}$

SoIl Drainage (MEAN):

MODERATELY WELL

ECOLOGICAL STATUS SCORE: 24

HEALTH FORM: RIPARIAN

\section{FORAGE PRODUCTION (KG/HA)}

TOTAL $1200 *$ ESTIMATE

ECOLOGICALLY SUSTAINABLE STOCKING RATE

Generally Non Use

$40.47 \mathrm{ha} / \mathrm{AUM}$

$0.01 \mathrm{AUM} / \mathrm{ac}$ 


\section{DMA26. Creeping spike rush \\ (Eleocharis palustris)}

$\mathbf{n = 2}$ Thompson and Hansen (2002) described this type on somewhat alkaline sites in narrow bands along streams, rivers, lake margins and reservoirs. These sites are subject to yearly flooding. Typically these sites are almost pure stands of creeping spike rush. Creeping spike rush is generally unpalatable to livestock and the wet conditions limit livestock use.

\section{Plant COMPOSITION Canopy Cover(\%)}

MEAN RANGE CONST.

\section{FORBS}

MARSH RAGWORT

(Senecio congestus)

SEASIDE BUTTERCUP

(Ranunculus cymbalaria) $\quad 10 \quad 0-20 \quad 50$

MARSH WILLOW HERB

(Epilobium palustre)

COMMON BURREED

(Sparganium eurycarpum)

\section{Grasses}

CREEPING SPIKE RUSH

(Eleocharis palustris)

COMMON BULRUSH

(Scirpus acutus)

FOXTAIL BARLEY

(Hordeum jubatum)

$\begin{array}{lll}2 & 1-3 & 100 \\ 10 & 0-20 & 50 \\ 5 & 0-10 & 50 \\ 5 & 0-10 & 50\end{array}$

$\begin{array}{lll}60 & 50-70 & 100 \\ 5 & 0-10 & 50 \\ 2 & 0-3 & 50\end{array}$

\section{ENVIRONMENTAL VARIABLES}

Moisture Regime (MEAN):

SUBHYDRIC

NUTRIENT REGIME (MEAN): PERMESOTROPHIC

ELEVATION: $600 \mathrm{M}$

SoIl Drainage (MEAN): POORLY

Ecological Status Score: 24

HEALTH FORM: RIPARIAN

\section{FORAGE PRODUCTION(KG/HA)}

TOTAL $1200 *$ EstimATE

ECOLOGICALLY SUSTAINABLE STOCKING RATE Generally Non Use $40.47 \mathrm{ha} / \mathrm{AUM}$ $0.01 \mathrm{AUM} / \mathrm{ac}$ 


\section{DMA27. Three square rush (Scirpus pungens)}

$\mathbf{n}=3$ This community is an edge community forming dense stands along the edges of smaller streams, marshes and ponds. Three square rush is also tolerant of alkaline ( $\mathrm{pH} \mathrm{8.5)} \mathrm{and} \mathrm{saline} \mathrm{soils} \mathrm{(Thompson} \mathrm{and} \mathrm{Hansen} \mathrm{2002)} \mathrm{and}$ can be found adjacent to saline areas in conjunction with prairie bulrush in the southern part of the region. The palatability of this species is low to moderate. Consequently, three square rush communities are seldom grazed by livestock.

\section{Plant Composition Canopy Cover(\%)}

MEAN RANGE CONST.

\section{SHRUBS}

SANDBAR WILLOW

(Salix exigua)

\section{FORBS}

SLENDER ARROW-GRASS

(Triglochin palustris)

SEASIDE BUTTERCUP

(Ranunculus cymbalaria)

HORSETAIL

(Equisetum arvense)

\section{Grasses}

THREE SQUARE RUSH

(Scirpus pungens)

FOXTAIL BARLEY

(Hordeum jubatum)

NutTALl's SALTGRASS

(Puccinellia nuttalliana)

ROUGH HAIRGRASS

(Agrostis scabra)

$1 \quad 0-1 \quad 33$

4

$0-10$

66

2

$0-3$

66

$3 \quad 0-10$

33

$\begin{array}{lll}60 & 50-70 & 100 \\ 4 & 0-10 & 66 \\ 2 & 0-3 & 66 \\ 2 & 0-3 & 66\end{array}$

\section{ENVIRONMENTAL VARIABLES}

Moisture Regime (MEAN):

SUBHYGRIC

Nutrient REgIME (MEAN):

SUBMESOTROPHIC

ELEVATION:

$606 \mathrm{M}$

SoIl DRAINAGE (MEAN):

POORLY

Ecological Status Score: 24

HEALTH FORM: RIPARIAN

\section{FORAGE PRODUCTION (KG/HA)}

Total $1200 *$ ESTIMATE

ECOLOGICALLY SUSTAINABLE STOCKING RATE

Generally Non Use

$40.47 \mathrm{ha} / \mathrm{AUM}$

$0.01 \mathrm{AUM} / \mathrm{ac}$ 


\section{DMA28. Prairie bulrush \\ (Scirpus paludosus)}

$\mathbf{n = 2}$ This community type is often associated with alkaline and saline areas in semi-permanently flooded shallow edges of marshes and ponds (Thompson and Hansen 2002). Three square rush is often associated with the drier edges of this community type. The palatability of this species is low to moderate. Consequently, prairie bulrush communities are seldom grazed by livestock.

\section{Plant COMPOSITION Canopy Cover(\%)}

$$
\text { MEAN RANGE CONST. }
$$

\section{GRASSES}

PRAIRIE BULRUSH

(Scirpus paludosus)

FOXTAIL BARLEY

(Hordeum jubatum)

NUTTALL'S SALTGRASS

(Puccinellia nuttalliana)

$\begin{array}{lll}98 & - & 100 \\ 1 & - & 100 \\ 1 & - & 100\end{array}$

\section{ENVIRONMENTAL VARIABLES}

Moisture Regime (MEAN):

SUBHYGRIC

Nutrient REgIME (MEAN):

SUBMESOTROPHIC

ELEVATION:

$600 \mathrm{M}$

Soll DRAINAGE (MEAN):

POORLY

ECological Status Score: 24

HEALTH FORM: RIPARIAN

\section{FORAGE PRODUCTION(KG/HA)}

Total $\quad 1200 *$ Estimate

ECOLOGICALLY SUSTAINABLE STOCKING RATE

Generally Non Use

$40.47 \mathrm{ha} / \mathrm{AUM}$

$0.01 \mathrm{AUM} / \mathrm{ac}$ 


\section{DMA29. Nuttall's saltgrass \\ (Puccinellia nuttalliana)}

$\mathbf{n = 2}$ This community is characteristic of saline and alkaline alluvial deposits adjacent to ponds, lake margins or seepage areas. This community type is fairly productive and heavy grazing will often lead to a community type dominated by foxtail barley.

\section{PLANT COMPOSITION CANopy Cover(\%)}

$$
\text { MEAN RANGE CONST. }
$$

\section{Grasse $S$}

NutTALL's SALTGRASS

(Puccinellia nuttalliana)

PRAIRIE BULRUSH

(Scirpus paludosus)

FOXTAIL BARLEY

(Hordeum jubatum)

$\begin{array}{lll}97 & 97-98 & 100 \\ 2 & 0-3 & 50 \\ 1 & 0-1 & 50\end{array}$

\section{ENVIRONMENTAL VARIABLES}

Moisture REgIME (MEAN): SUBHYGRIC

NutRIENT REGIME (MEAN): SUBMESOTROPHIC

ELEVATION:

$600 \mathrm{M}$

SoIl DRAINAGE (MEAN):

Moderately Well

Ecological Status Score: 24

HEALTH FORM: RIPARIAN

\section{FORAGE PRODUCTION(KG/HA)}

Total $1500 *$ Estimate

\begin{tabular}{|l||}
\hline ECOLOGICALLY SUSTAINABLE STOCKING RATE \\
$4.05 \mathrm{ha} / \mathrm{AUM}$ \\
$0.10 \mathrm{AUM} / \mathrm{ac}$ \\
\end{tabular}




\section{DMA30. Foxtail barley \\ (Hordeum jubatum)}

$\mathbf{n = 2}$ This community represents a disturbance community. It can result from heavy grazing of tame pastures or native meadows in slightly saline areas. This community can also form on the edges of receding lake shores. As the lake drys foxtail barley will invade onto the drier edges. Foxtail barley is generally unpalatable to livestock and the seeds can get stuck in the animals mouth causing sores. Despite the high productivity of these sites they are often never used by livestock.

\section{PLANT COMPOSITION CANOPY Cover(\%)}

MEAN RANGE CONST.

\section{FORBS}

SEASIDE BUtTERCUP

(Ranunculus cymbalaria)

DANDELION

(Taraxacum officinale)

SEA SIDE ARROW-GRASS

(Triglochin maritima)

\section{Grasses}

FOXTAIL BARLEY

(Hordeum jubatum)

NutTALL'S SALTGRASS

(Puccinellia nuttalliana)

CREEPING SPIKE RUSH

(Eleocharis palustris)

THREE SQUARE RUSH

(Scirpus pungens)

$\begin{array}{lll}2 & 0-3 & 50 \\ 1 & 0-1 & 50 \\ 1 & 0-1 & 50\end{array}$

80

80-81 100

$1 \quad 1-2 \quad 100$

$5 \quad 0-10 \quad 50$

2

$0-3$

50

\section{ENVIRONMENTAL VARIABLES}

MoISTURE REgIME (MEAN):

$$
\text { SUBHYGRIC }
$$

NUTRIENT REGIME (MEAN):

SUBMESOTROPHIC

ElEvation: $600 \mathrm{M}$

SoIl DRAINAGE (MEAN):

$$
\text { IMPERFECTLY }
$$

ECOlogical Status SCORE: 8

HEALTH FORM: RIPARIAN

\section{FORAGE PRODUCTION(KG/HA)}

Total $1500 *$ ESTIMATE

ECOLOGICALLY SUSTAINABLE STOCKING RATE

Generally Non Use

$40.47 \mathrm{ha} / \mathrm{AUM}$

$0.01 \mathrm{AUM} / \mathrm{ac}$ 


\section{DRY MIXEDWOOD SUBREGION}

TAME FORAGE COMMUNITIES

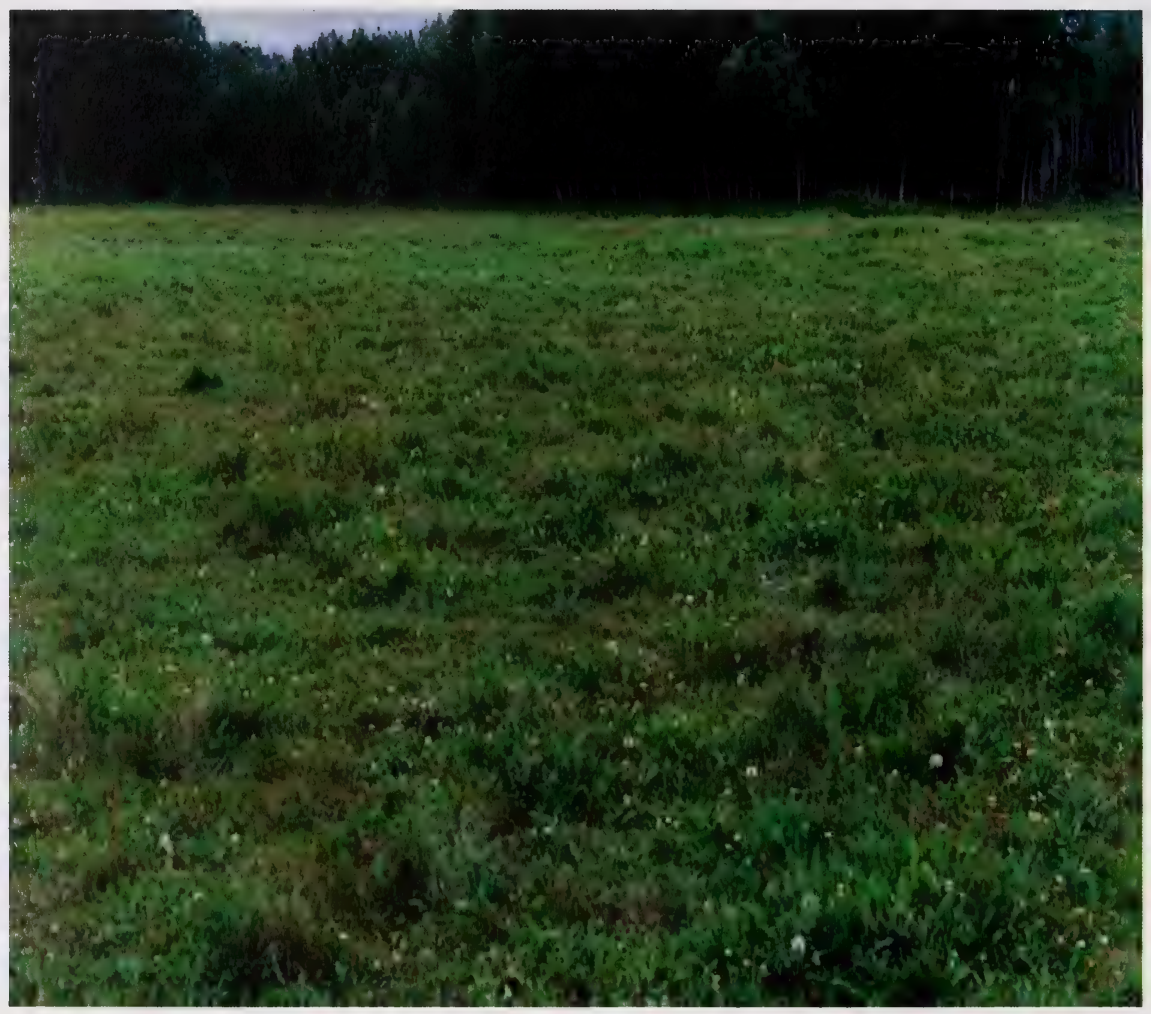

Photo 3. Typical Range improvement clearing in the Dry Mixedwood subregion. 


\section{TAME FORAGE COMMUNITIES}

\section{(Cleared areas that have been broken and seeded to tame forage)}

Throughout the Dry mixedwood subregion there are sites that have been deforested, broken, and seeded to tame forage. Usually these areas are mesic and moderately well to well drained with good nutrient levels. Because most of these tame forage stands are established on similar sites, the most influential factors affecting plant species composition are stand establishment and grazing regime.

Stand establishment is important because it determines what the initial plant species composition is going to be. Seed bed preparation and the type of seed sown are the two most important factors influencing stand establishment. Seed bed preparation is important because it helps to determine how well the sown seed germinates and establishes. If the seed bed is not well prepared, the tame forage species may have reduced seedling vigour and/or density allowing native or weedy species to become a dominant component of the plant community.

After the stand is established, the grazing regime applied to the stand will influence the plant species composition. Generally, a light to moderate level of grazing allows the stand to maintain itself while sustained heavy grazing causes the stand to degrade. Damage to a stand due to overgrazing occurs more readily while the stand is establishing than it does when the stand is established. This is because the forage plants in an establishing stand have not had time to develop energy reserves or substantial root systems and are therefore more susceptible to grazing induced stress.

Figure 6 is a successional diagram for tame pastures in the Dry Mixedwood subregion. Tame pasture communities are organized horizontally by moisture gradient [e.g. dry (submesic) to moist (subhygric)] and vertically by successional factors like the grazing disturbance gradient [e.g. moderate or very heavily grazed] or stand establishment. A light to moderate grazing regime will normally maintain a forage stand similar to what was seeded on the site. These stands are generally the most productive and provide the best grazing opportunities for livestock. In figure 6 , these plant communities are indicated by the bolded boxes and represent various seed mixes sown on submesic to subhygric sites (not just those species in the plant community name) They are considered to be in the healthy category for range health.

The plant communities represented by the boxes above the bolded boxes may be the result of a number of different factors. For example, when the site is under-grazed, the stand becomes dominated by species that are the most competitive in the absence of grazing disturbance. In this case, trees and shrubs growth is unchecked and they can out-compete seeded plants for light and other resources. Poor forage establishment is another factor that can result in stands that are dominated by native or weedy species. Although shrubs and trees can occur on all tame pasture community types, the extent to which invasion occurs is influenced by site preparation, forage establishment, moisture conditions, age of stand and grazing history.

Plant community changes which occur under heavy grazing are dependent on the grazing history (level of use, season of use and duration of the grazing regime). Overgrazed community types [plant communities at bottom of Figure 6] develop over a long period of repeated overgrazing. If weedy species such as tall buttercup or Canada thistle, become established on overgrazed sites, they can quickly become a dominant species. 
Figure 6. Successional sequences of tame pasture communities on 3 moisture regimes in the Dry Mixedwood subregion.

\begin{tabular}{|c|c|c|c|c|}
\hline & $\begin{array}{l}\text { SUBMESIC } \\
\text { SITES }\end{array}$ & MESIC SITES & $\begin{array}{l}\text { SUBHYGRIC } \\
\text { SITES }\end{array}$ & \\
\hline $\begin{array}{c}\text { SUCCESSIONAL } \\
\text { CHANGES }\end{array}$ & & & & $\begin{array}{c}\text { SUCCESSION } \\
\text { FACTORS }\end{array}$ \\
\hline $\begin{array}{l}\text { tree species become } \\
\text { dominant }\end{array}$ & \begin{tabular}{|l}
$\mathrm{Aw}-\mathrm{Pb} / \mathrm{Rose} / \mathrm{H}$. \\
wild rye \\
$\mathrm{DMB} 23$
\end{tabular} & \begin{tabular}{|l} 
Aw / Rose / \\
Strawberry DMB21
\end{tabular} & & \\
\hline $\begin{array}{l}\text { some woody } \\
\text { regrowth and native } \\
\text { herbaceous species }\end{array}$ & \begin{tabular}{|l} 
Rose / Dandelion / \\
H. wild rye \\
DMB22 \\
\end{tabular} & \begin{tabular}{|l|} 
Rose / C. red \\
fescue- Sedge \\
DMB20 \\
\end{tabular} & $\begin{array}{l}\text { Willow / Timothy } \\
\text { DMB24 }\end{array}$ & \\
\hline $\begin{array}{l}\text { reversion to native } \\
\text { plants }\end{array}$ & & & & $\begin{array}{c}\text { poor stand } \\
\text { establishment or } \\
\text { under-grazing }\end{array}$ \\
\hline $\begin{array}{l}\text { dominated by the } \\
\text { tall, productive } \\
\text { species originally } \\
\text { seeded [i.e. desirable } \\
\text { species] }\end{array}$ & $\begin{array}{c}\text { Wheat grass / } \\
\text { Creeping red fescue } \\
\text { DMB19 }\end{array}$ & $\begin{array}{c}\text { Brome / Timothy } \\
\text { DMB12 }\end{array}$ & $\begin{array}{c}\text { R. canary grass- } \\
\text { Meadow foxtail- } \\
\text { Timothy-Brome } \\
\text { DMB16 }\end{array}$ & $\begin{array}{l}\text { light to } \\
\text { moderately } \\
\text { grazed }\end{array}$ \\
\hline & & & & $\begin{array}{l}\text { moderately to } \\
\text { heavily grazed }\end{array}$ \\
\hline $\begin{array}{l}\text { decline in desirable } \\
\text { species with some } \\
\text { grazing induced } \\
\text { species present }\end{array}$ & & \begin{tabular}{|l|} 
Brome - Timothy - \\
C. red fescue \\
DMB13
\end{tabular} & $\begin{array}{l}\text { Brome -C. red } \\
\text { fescue- K. bluegrass / } \\
\text { Dandelion } \\
\text { DMB17 }\end{array}$ & \\
\hline $\begin{array}{l}\text { dominated by } \\
\text { grazing induced } \\
\text { species with some } \\
\text { weedy species }\end{array}$ & & \begin{tabular}{|l|} 
C. red fescue - \\
K. bluegrass / \\
Dandelion \\
DMB14 \\
\end{tabular} & & heavily grazed \\
\hline $\begin{array}{l}\text { dominated by } \\
\text { grazing induced } \\
\text { and/or weedy } \\
\text { species }\end{array}$ & $\begin{array}{l}\text { Strawberry- } \\
\text { Dandelion/Weeds } \\
\text { DMB15 }\end{array}$ & \begin{tabular}{|l} 
Strawberry- \\
Dandelion/Weeds \\
DMB15
\end{tabular} & $\begin{array}{l}\text { Foxtail barley/Weeds } \\
\text { DMB18 }\end{array}$ & $\begin{array}{l}\text { very heavily } \\
\text { grazed }\end{array}$ \\
\hline
\end{tabular}




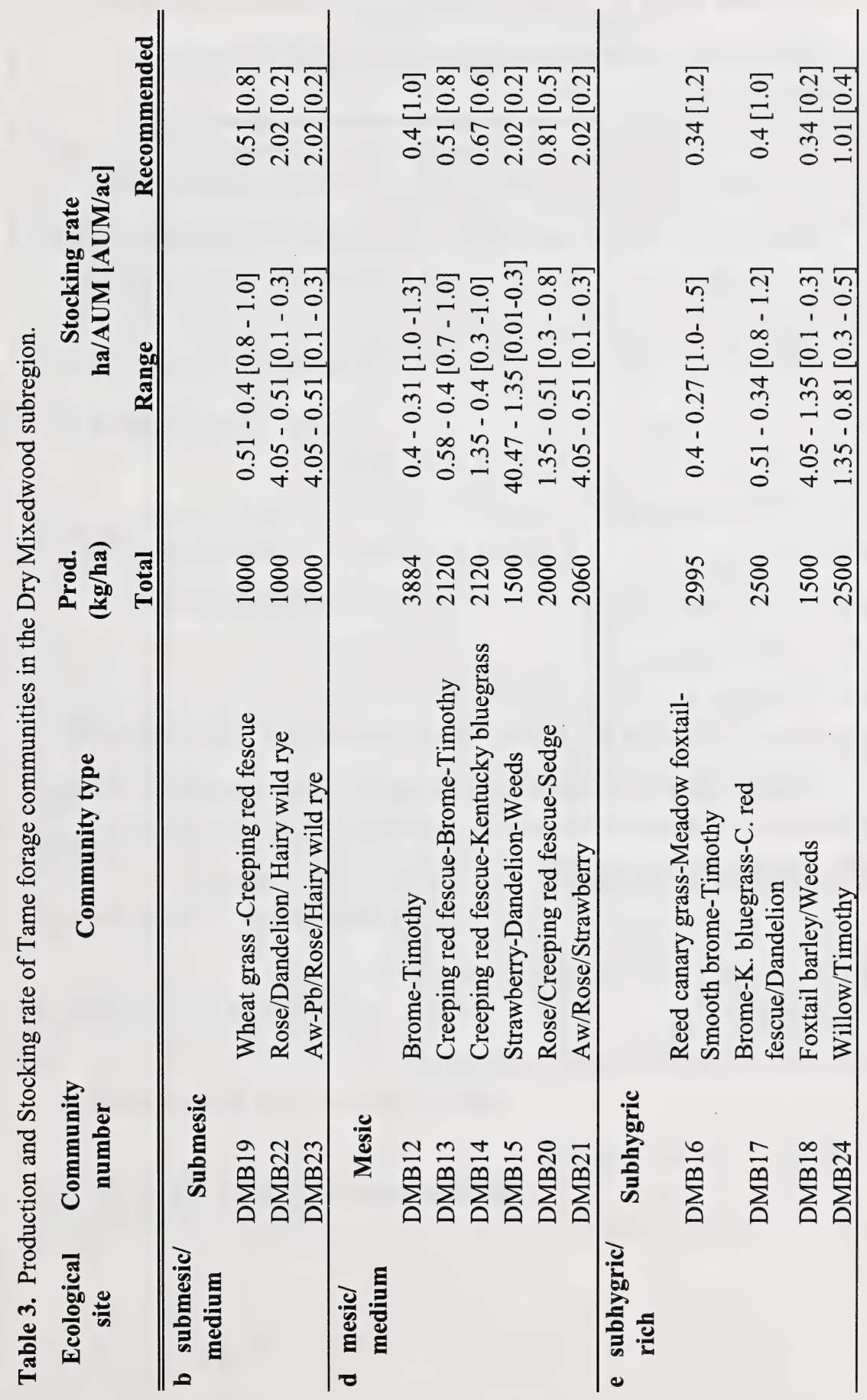




\section{Key to Tame Grass Plant Communities - Dry Mixedwood Subregion}

1. Tame forage stand dominated by tall productive species, grazing has not caused an increase of grazing resistant or weedy species $\ldots \ldots \ldots \ldots \ldots \ldots \ldots \ldots \ldots \ldots \ldots \ldots \ldots \ldots \ldots \ldots \ldots \ldots \ldots$ Tame forage stand modified by overgrazing with grazing resistant species at least co-dominant in the plant community; or the site has aspen or shrub invasion $\ldots \ldots \ldots \ldots \ldots$

2. Subhygric sites dominated by productive, moisture loving tame forage species seeded on the site [e.g. reed canary grass, meadow foxtail or timothy].

..Reed Canary Grass-Meadow Foxtail-Smooth brome-Timothy (DMB16)

Mesic or submesic sites dominated by productive tame forage species suited to normal or dry moisture conditions [e.g. smooth brome, meadow brome, timothy, wheat grass, etc.] . . . . 3

3. Submesic sites with wheat grass and creeping red fescue

Crested wheat grass-Creeping Red Fescue (DMB19)

Mesic sites dominated by other tall, productive tame forage species [e.g. smooth brome, meadow brome, timothy, etc.].

Brome / Timothy (DMB12)

4. Tame pasture invaded by aspen, balsam poplar or shrub species................................... . 9

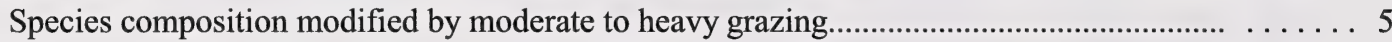

5. Pasture moderately to heavily grazed; tall, productive and grazing resistant species co-dominate the site .Creeping Red Fescue - Brome-Timothy (DMB13)

Pasture heavily to very heavily grazed; grazing resistant and/or weedy species dominate the site . . 6

6. Pasture heavily grazed; grazing resistant forage species dominate the site; dandelion,

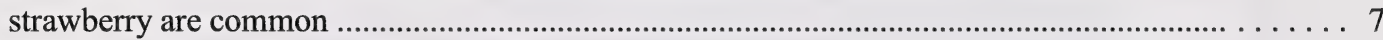

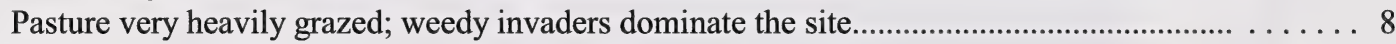

7. Subhygric sites; dominated by grazing resistant species

Brome-Creeping Red Fescue- Kentucky Bluegrass-Dandelion (DMB17)

Mesic sites; dominated by grazing resistant species

Creeping Red Fescue-Kentucky Bluegrass-Clover / Dandelion (DMB14)

8. Mesic or submesic sites dominated by strawberry, dandelion, Canada thistle and other weedy species.

Strawberry / Dandelion / Weeds (DMB15)

Subhygric sites dominated by foxtail barley, Canada thistle or other weedy spp

.Foxtail barley / Weeds (DMB18)

9. Old tame pastures with Aspen and Balsam Poplar invasion........................................... . . 10

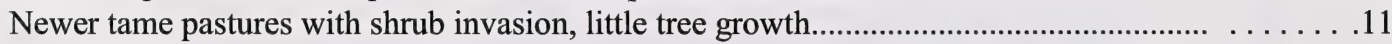

10. Mesic sites with strawberry

Aw/Rose/Strawberry (DMB21)

Submesic sites with hairy wild rye

Aw-Pb/Rose/Hairy wild rye (DMB23)

11. Submesic sites dominated by hairy wild rye and rose

Rose/Dandelion/Hairy wild rye (DMB22)

Mesic to subhygric sites

12. Mesic sites with marsh reed grass and sedge.

Rose/Creeping red fescue-Sedge (DMB20)

Subhygric sites with willow invading. Willow/Timothy (DMB24) 


\section{DMB12. Brome-Timothy \\ (Bromus inermis, B. biebersteinii-Phleum pratense)}

$\mathbf{n = 9} \quad$ This community type represents healthy condition tame pasture on mesic sites that were seeded with a timothy, smooth brome, meadow brome, creeping red fescue, alfalfa, clover mixture. Timothy establishes much quicker than creeping red fescue or smooth brome on pastures that have been recently seeded. Eventually creeping red fescue and smooth brome will outcompete timothy and this community will likely become dominated by creeping red fescue and smooth brome. Heavy to moderate grazing pressure will cause the tall growing grass species (Brome, timothy) to decline and allows low growing Kentucky bluegrass and dandelion to increase to form communities DMB13 and DMB14. Continued heavy grazing pressure will eventually lead to a community dominated by dandelion and weeds (DMB15). Light or no grazing or poor seed establishment will allow native trees, shrubs, forbs and grass to invade onto these sites to form communities DMB20 and 21 .

\section{PLANT COMPOSITION Canopy Cover(\%)}

\section{SHRUBS}

PRICKLY ROSE

(Rosa acicularis)

FORBS

Clover

(Trifolium spp.)

DANDELION

(Taraxacum officinale)

WILD STRAWBERRY

(Fragaria virginiana)

Grasses

Creeping Red Fescue

(Festuca rubra)

Tімотну

(Phleum pratense)

KeNTUCKY BLUEGRASS

(Poa pratensis)

SMOOTH BROME

(Bromus inermis)

MEADOW BROME

(Bromus biebersteinii)
MEAN RANGE CONST.

$1 \quad 0-4$

22

44

$10 \quad 0-45 \quad 67$

$\begin{array}{lll}15 & 0-47 & 78\end{array}$

$8 \quad 0-60 \quad 46$

$1 \quad 0-3 \quad 33$

$49 \quad 25-77 \quad 100$

$10 \quad 0-56 \quad 44$

\section{ENVIRONMENTAL VARIABLES}

Moisture Regime (MEAN):

MESIC-SUBHYGRIC

NUTRIENT REGIME (MEAN):

MEDIUM-RICH

ELEVATION:

457-606 (587)M

SoIl Drainage (MEAN):

WELL TO MODERATELY WELL

DESIRABLE SPECIES SHIFT SCORE: 8

\section{FORAGE PRODUCTION (KG/HA)}

TOTAL 3884

ECOLOGICAL SUSTAINABLE STOCKING RATE

$0.4 \mathrm{ha} / \mathrm{AUM}(0.4-0.31)$

$1.0 \mathrm{AUM} / \mathrm{ac}(1.0-1.3)$ 


\section{DMB13. Creeping red fescue- Brome-Timothy \\ (Festuca-rubra-Bromus spp.-Phleum pratense)}

$\mathbf{n = 1 2}$ This community type develops on mesic sites that were seeded to a mixture of brome, timothy or other productive species with some grazing resistant species like creeping red fescue, A history of moderate to heavy grazing pressure results in a decline in the proportions of tall, productive species and an increase in the grazing resistant species. Heavy continuous grazing will allow Kentucky bluegrass and dandelion to invade into the stand to form a Kentucky bluegrass or Quackgrass/Dandelion dominated community type.

\section{Plant Composition Canopy Cover $(\%)$}

TreES

MEAN RANGE CONST.

ASPEN

(Populus tremuloides)

$20-10$

33

SHRUBS

RosE

(Rosa acicularis)

2

$0-5$

75

FORBS

Clover

(Trifolium spp.)

DANDELION

(Taraxacum officinale)

STRAWBERRY

(Fragaria virginiana)

Grasses

Creeping Red Fescue

(Festuca rubra)

Tімотну

(Phleum pratense)

KentuCKy Bluegrass

(Poa pratensis)

SMOоTH BROME

(Bromus inermis)

$\begin{array}{lll}41 & 9-78 & 100 \\ 9 & 0-25 & 83 \\ 5 & 0-23 & 67 \\ 15 & 0-75 & 50\end{array}$

\section{ENVIRONMENTAL VARIABLES}

MOISTURE REGIME (MEAN):

MESIC

NUTRIENT REGIME (MEAN):

MEDIUM

ELEVATION:

$609 \mathrm{M}$

SoIl DrainAge (MEAN):

WELL

DESIRABLE SPECIES SHIFT SCORE: 4

\section{FORAGE PRODUCTION(KG/HA)}

TotAL 2120

ECOLOGICALLY SUSTAINABLE STOCKING RATE

$0.51 \mathrm{ha} / \mathrm{AUM}(0.58-0.4)$

$0.8 \mathrm{AUM} / \mathrm{ac}(0.7-1.0)$ 


\section{DMB14. Creeping red fescue-Kentucky bluegrass/Dandelion (Festuca rubra-Poa pratensis/ Taraxacum officinale)}

$\mathbf{n = 3 1}$ This community is representative of heavily grazed mesic sites and is dominated by grazing resistant species like Kentucky bluegrass, creeping red fescue or quackgrass. Heavy grazing tends to favour the growth of these low-growing or rhizomatuous species and that of weedy or disturbance induced species such as dandelion. These sites have poor health ratings and lower production than community types dominated by species like timothy and brome.

\section{Plant COMPOSITION Canopy Cover(\%)}

SHRUBS

RASPBERRY.

(Rubus idaeus.)

MEAN RANGE CONST.

Forbs

Clover

(Trifolium spp.)

DANDELION

(Taraxacum officinale)

STRAWBERRY

(Fragaria virginiana)

Grasses

Creeping Red Fescue

(Festuca rubra)

Тімотну

(Phleum pratense)

SмоOTH BROME

(Bromus inermis)

KENTUCKY BLUEGRASS

(Poa pratensis)

QUACKGRASS

(Agropyron repens)
$1 \quad 0-30$

25

13

$0-45$

100

$21 \quad 0-42$

91

$2 \quad 0-4$

72

15

0-75

40

3

$0-13$

53

$2 \quad 0-3$

25

$15 \quad 0-36 \quad 78$

$5 \quad 0-45$

20

\section{ENVIRONMENTAL VARIABLES}

Moisture REgime (MEAN):

MESIC

NUTRIENT REGIME (MEAN):

MEDIUM

ELEVATION:

576-701(658)M

Soll Drainage (MEAN):

WELL

DESIRABLE SPECIES SHIFT SCORE: 0

\section{FORAGE PRODUCTION (KG/HA)}

TOTAL 2120

ECOLOGICALLY SUSTAINABLE STOCKING RATE

$0.67 \mathrm{ha} / \mathrm{AUM}(1.35-0.4)$

$0.6 \mathrm{AUM} / \mathrm{ac}(0.3-1.0)$ 


\section{DMB15. Strawberry-Dandelion-Weeds \\ (Fragaria virginiana-Taraxacum officinale-Cirsium arvensis)}

$\mathbf{n}=\mathbf{6}$ This community represents extremely heavily grazed mesic pasture sites. Generally, all that is left growing on these areas is dandelion. There also tends to be a lot of bare soil, which provides a place for noxious weeds (Canada thistle) to become established.

\section{PLANT COMPOSITION CANOPY Cover(\%)}

$$
\text { MEAN RANGE CONST. }
$$

\section{CONST.}

\section{FORBS}

STRAWBERRY

(Fragaria virginiana)

Clover

(Trifolium spp.)

DANDELION

(Taraxacum officinale)

CANADA THISTLE

(Cirsium arvense)

Grasses

TIMOTHY

(Phleum pratense)

CREEPING RED FESCUE

(Festuca rubra)

Kentucky Bluegrass

(Poa pratensis)

$\begin{array}{lll}2 & 0-8 & 50 \\ 1 & 0-6 & 50 \\ 44 & 19-75 & 100 \\ 5 & 0-29 & 33\end{array}$

$\begin{array}{lll}2 & 0-7 & 67 \\ 1 & 0-1 & 67 \\ 17 & 3-74 & 100\end{array}$

\section{ENVIRONMENTAL VARIABLES}

MoISTURE REgIME (MEAN):

MESIC

NUTRIENT REGIME (MEAN):

MEDIUM

ELEVATION:

$455 \mathrm{M}$

SoIl DrainAge (MEAN):

WELL

Plant Composition: TAME or Modified TAME

DESIRABLE SPECIES SHIFT SCORE: 0

FORAGE PRODUCTION (KG/HA)

TOTAL 1500

ECOLOGICALLY SUSTAINABLE STOCKING RATE

$2.02 \mathrm{ha} / \mathrm{AUM}(40.47-1.35)$

$0.2 \mathrm{AUM} / \mathrm{ac}$ (0.01-0.3) 


\section{DMB16. Reed canary grass-Meadow foxtail-Smooth brome-Timothy (Phalaris arundinacea-Alopecurus pratensis-Bromus inermis-Phleum pratense)}

$\mathbf{n}=\mathbf{2}$ This community type represents seeded areas on moist (subhygric) rich sites. Reed canary grass and meadow foxtail establish quickly in wet places that have been disturbed and will dominate very wet sites. Care should be taken when seeding reed canary grass. It appears that the commercial cultivars can be very invasive (Invasive plants of natural habitats 1992). In areas that have supported reed canary grass monocultures for extended periods many have seed banks devoid of other species. Meadow foxtail also seems particularly prone to increasing on moister grazed sites as it starts growth and heads out early. Meadow foxtail becomes unpalatable and is avoided by livestock if it is not grazed early enough in the spring.

\section{PLANT COMPOSITION Canopy Cover(\%)}

MEAN RANGE CONST.

FORBS

AMERICAN VETCH

(Vicia americana)

DANDELION

(Taraxacum officinale)

STRAWBERRY

(Fragaria virginiana)

Clover

(Trifolium spp.)

\section{Grasses}

REED CANARY GRASS

(Phalaris arundinacea)

TIMOTHY

(Phleum pratense)

SMOOTH BROME

(Bromus inermis)

CREEPING RED FESCUE

(Festuca rubra)

MEADOW FOXTAIL

(Alopecurus pratensis)

\section{ENVIRONMENTAL VARIABLES}

Moisture REgIME (MEAN):

SUBHYGRIC

Nutrient Regime (MEAN):

$\mathrm{RICH}$

ELEVATION:

$579-606 \mathrm{M}$

SoIL DraINAGE (MEAN):

WELL

DESIRABLE SPECIES SHIFT SCORE: 8

\section{FORAGE PRODUCTION(KG/HA)}

TOTAL 2995

ECOLOGICALLY SUSTAINABLE STOCKING RATE

$$
\begin{gathered}
0.34 \mathrm{ha} / \mathrm{AUM}(0.4-0.27) \\
1.2 \mathrm{AUM} / \mathrm{ac}(1.0-1.5)
\end{gathered}
$$




\section{DMB17. Brome-Creeping red fescue-Kentucky bluegrass/Dandelion (Bromus spp.-Festuca rubra-Poa pratensis/Taraxacum officinale)}

$\mathbf{n}=\mathbf{3}$ This community represents moderately grazed subhygric sites. Heavy continuous grazing will allow

Kentucky bluegrass and dandelion to invade into the stand to form a Kentucky bluegrass or

Quackgrass/Dandelion dominated community type. Continued heavy grazing pressure may eventually lead to site dominated by foxtail barley.

\section{Plant Composition Canopy Cover(\%)}

MEAN RANGE CONST.

\section{FORBS}

\section{Clover}

(Trifolium spp.)

DANDELION

(Taraxacum officinale)

HORSETAIL

(Equisetum arvense)

STRAWBERRY

(Fragaria virginiana)

\section{Grasses}

Creeping Red Fescue (Festuca rubra)

MEADOW BROME

(Bromus biebersteinii)

SEDGE

(Carex spp.)

KENTUCKY BLUEGRASS

(Poa pratensis)

Тімотну

(Phleum pratense)

$\begin{array}{lll}19 & 6-31 & 100 \\ 29 & 15-38 & 100 \\ 4 & 2-6 & 100 \\ 2 & 1-2 & 100\end{array}$

$62 \quad 40-80 \quad 100$

$21 \quad 17-23 \quad 100$

$16 \quad 1-45 \quad 100$

$5 \quad 1-10 \quad 100$

$3 \quad 2-4 \quad 100$

\section{ENVIRONMENTAL VARIABLES}

MoISTURE REgIME (MEAN): SUBHYGRIC

NUTRIENT REGIME (MEAN): PERMESOTROPHIC

ELEVATION:

$667 \mathrm{M}$

Soll Drainage (MEAN): MODERATELY WELL

DESIRABLE SPECIES SHIFT SCORE: 4

FORAGE PRODUCTION(KG/HA)

TOTAL 2500

ECOLOGICALLY SUSTAINABLE STOCKING RATE

$$
\begin{gathered}
0.4 \mathrm{ha} / \mathrm{AUM}(0.51-0.34) \\
1.0 \mathrm{AUM} / \mathrm{ac}(0.8-1.2)
\end{gathered}
$$




\section{DMB18. Foxtail barley/Weeds \\ (Hordeum jubatum/Cirsium arvensis)}

$\mathbf{n}=\mathbf{1}$ This community type develops on heavily grazed subhygric moist sites. This community was found in depressional areas and on river flood plains. Foxtail barley is also well adapted to growing on saline soils (Bailey et al. 1992). It is likely that the soils of this site are slightly saline. This community type would be considered non-use because the principle forage species foxtail barley is generally unpalatable to livestock. Foxtail barley can also cause injury to livestock. The sharp seeds and awns may work their way into tongues, gums, eyes, noses or skins of animals.

\section{Plant Composition Canopy Cover(\%)}

MEAN RANGE CONST.

\section{FORBS}

Alfalfa

(Medicago falcata.)

DANDELION

(Taraxacum officinale)

SWEET CLOVER

(Melilotus officinalis)

Clover

(Trifolium spp.)

\section{Grasses}

FOXTAIL BARLEY

(Hordeum jubatum)

SMOOTH BROME

(Bromus inermis)

Тімотну

(Phleum pratense)

FOWL BLUEGRASS

(Poa palustris)

$\begin{array}{lll}11- & 100 \\ 1 & - & 100 \\ 4 & - & 100 \\ 5 & - & 100\end{array}$

$\begin{array}{lll}69 & - & 100 \\ 1 & - & 100 \\ 18 & - & 100 \\ 1 & - & 100\end{array}$

\section{ENVIRONMENTAL VARIABLES}

Moisture Regime (MEAN):

SUBHYGRIC

NUTRIENT REGIME (MEAN):

RICH

ELEVATION:

457-606(597)M

SoIl Drainage (MEAN): Well

Plant Composition: TAMe or Modified TAme

Desirable Species Shift Score: 0

\section{FORAGE PRODUCTION(KG/HA)}

TotAL 1500

ECOLOGICALLY SUSTAINABLE STOCKING RATE $0.34 \mathrm{ha} / \mathrm{AUM}(4.05-1.35)$

$0.2 \mathrm{AUM} / \mathrm{ac}(0.1-0.3)$ 


\section{DMB19. Wheat grass-Creeping red fescue-Timothy (Agropyron pectiniforme-Festuca rubra-Phleum pratense)}

$\mathbf{n}=\mathbf{1}$ This community type occurs on cleared pastures that were seeded on submesic (dry) sites in the eastern part of the subregion near St. Paul. These sites occur on very stoney well drained soils and it was thought crested wheat grass would grow well in these site conditions. These pastures were seeded in the late 1980's with a mixture of pubescent wheat grass, timothy, creeping red fescue, alfalfa, crested wheat grass and sweet clover. Crested wheat grass and creeping red fescue were found to dominate the dry hilltops and timothy was found on the moist lowland sites. There was little evidence of pubescent wheat grass, alfalfa or sweet clover surviving from the original mix. These pastures often undergo succession to a shrub dominated community (DMB 11) and then a deciduous dominated community type (DMB9).

\section{Plant COMPOSITION Canopy Cover(\%)}

MEAN RANGE CONST.

\section{SHRUBS}

PRICKLY ROSE

(Rosa acicularis)

1

100

FORBS

Clover

(Trifolium spp.)

DANDELION

(Taraxacum offincinale)

BEARBERRY

(Arctostaphylos uva-ursi)

Grasses

Creeping Red Fescue

(Festuca rubra)

CRESTED Wheat GRASS

(Agropyron pectiniforme)

TIMOTHY

(Phleum pratense)

KENTUCKY BLUEGRASS

(Poa pratensis)

100

\section{ENVIRONMENTAL VARIABLES}

Moisture REGIME (MEAN):

SUBMESIC

NUTRIENT REGIME (MEAN): MESOTROPHIC

\section{ELEVATION:}

$579 \mathrm{M}$

SoIl Drainage (MEAN): WELL

DESIRABLE SPECIES SHIFT SCORE: 8

\section{FORAGE PRODUCTION(KG/HA)}

TOTAL 1000

ECOLOGICALLY SUSTAINABLE STOCKING RATE

$$
0.51 \mathrm{ha} / \mathrm{AUM}(0.51-0.4)
$$

$0.8 \mathrm{AUM} / \mathrm{ac}(0.8-1.0)$ 


\section{DMB20. Rose/Creeping red fescue-Sedge (Rosa acicularis/Festuca rubra-Carex spp.)}

$\mathbf{n}=\mathbf{5}$ As seeded pastures undergo succession back to a deciduous dominated forest they are often invaded by rose and willow before the trees become dominant. This community represents an early successional

community of DMB21. Burning, cultivation and spraying with herbicide are all options that can be considered in order to control shrub regrowth. On mesic sites marsh reed grass tends to be the native grass that invades. In contrast hairy wild rye will invade on drier sites.

\section{Plant Composition Canopy Cover $(\%)$}

TREES

ASPEN

(Populus tremuloides)

MEAN RANGE CONST.

\section{SHRUBS}

PRICKLY ROSE

(Rosa acicularis)

FORBS

Clover

(Trifolium spp.)

DANDELION

(Taraxacum officinale)

WILD STAWBERRY

(Fragaria virginiana)

\section{Grasses}

Creeping Red Fescue

(Festuca rubra)

Тімотну

(Phleum pratense)

KENTUCKY BLUEGRASS

(Poa pratensis)

HAIRY WILD RYE

(Elymus innovatus)

MARSH REED GRASS

(Calamagrostis canadensis) 3

SEDGE

(Carex spp.)

$\begin{array}{lll}12 & 1-25 & 100 \\ 7 & 0-14 & 80 \\ 2 & 1-7 & 100 \\ 8 & 1-23 & 100\end{array}$

$19 \quad 0-64 \quad 80$

$4 \quad 0-12 \quad 60$

$2 \quad 0-7 \quad 60$

$1 \quad 0-3 \quad 40$

$0-13 \quad 20$

$0-24 \quad 80$

\section{ENVIRONMENTAL VARIABLES}

Moisture Regime (MEAN):

MESIC

NUTRIENT REGIME (MEAN):

MEDIUM

ELEVATION:

603(600-606)M

Soll Drainage (MEAN): WELL

Plant Composition: TAME oR Modified TAME

DESIRABLE SPECIES SHIFT SCORE: 0

\section{FORAGE PRODUCTION(KG/HA)}

TotAL 2000

ECOLOGICALLY SUSTAINABLE STOCKING RATE

$0.81 \mathrm{ha} / \mathrm{AUM}(1.35-0.51)$

$0.5 \mathrm{AUM} / \mathrm{ac}(0.3-0.8)$ 


\section{DMB21. Aw/Rose/Strawberry (Populus tremuloides/Rosa acicularis/Fragaria virginiana)}

$\mathbf{n}=\mathbf{5}$ This community type occurs in mesic cultivated pastures that are being invaded by aspen. No grazing pressure or only light grazing pressure allows aspen to recolonize these cultivated pastures. Burning,

cultivation and spraying with herbicide are all options that can be considered in order to control aspen regrowth.

\section{Plant COMPOSITION Canopy Cover(\%)}

$$
\text { MEAN RANGE CONST. }
$$

TREES

ASPEN

(Populus tremuloides)

BALSAM POPLAR

(Populus balsamifera)

$\begin{array}{lll}14 & 8-20 & 100 \\ 1 & 0-1 & 40\end{array}$

\section{SHRUBS}

PRICKLY ROSE

(Rosa acicularis)

WILLOW

(Salix bebbiana)

SNOWBERRY

(Symphoricarpos

occidentalis)

FORBS

Clover

(Trifolium spp.)

DANDELION

(Taraxacum offincinale)

WILD STAWBERRY

(Fragaria virginiana)

$5 \quad 2-12$

\section{GRASSES}

Creeping Red Fescue

(Festuca rubra)

Тімотну

(Phleum pratense)

KENTUCKY BLUEGRASS

(Poa pratensis)

HAIRY WILD RYE

(Elymus innovatus)

MARSH REED GRASS

(Calamagrostis canadensis) 1

$\begin{array}{lll}3 & 1-4 & 100 \\ 1 & 0-4 & 20 \\ 1 & 0-2 & 60\end{array}$

$2 \quad 0-5 \quad 60$

$15 \quad 0-40 \quad 80$

100

0

0

\section{ENVIRONMENTAL VARIABLES}

MoISTURE REGIME (MEAN):

MESIC

Nutrient REgIME (MEAN):

MESOTROPHIC

Elevation:

$600 \mathrm{M}$

Soil Drainage (MEAN): Well

Plant COMPosition: TAME OR MOdified TAME

DESIRABLE SPECIES SHIFT SCORE: 0

FORAGE PRODUCTION(KG/HA)

TOTAL 2060

ECOLOGICALLY SUSTAINABLE STOCKING RATE

$2.02 \mathrm{ha} / \mathrm{AUM}(4.05-0.51)$

0.2 AUM/ac (0.1-0.3) 


\section{DMB22. Rose/Dandelion/Hairy wild rye (Rosa acicularis/Taraxacum officinale/Elymus innovatus)}

$\mathbf{n = 1}$ This community represents early invasion of shrubs onto drier (submesic) sites on pastures in the St. Paul area of the subregion. As seeded pastures undergo succession back to a deciduous dominated forest they are often invaded by rose and willow before the trees become dominant. This community represents an early successional community of DMB23. Burning, cultivation and spraying with herbicide are all options that can be considered in order to control shrub regrowth.

\section{Plant CoMposition Canopy Cover(\%)}

TREES

ASPEN

(Populus tremuloides)

BALSAM POPLAR

(Populus balsamifera)

\section{SHRUBS}

PRICKLY ROSE

(Rosa acicularis)

WILLOW

(Salix bebbiana)

SNOWBERRY

(Symphoricarpos

occidentalis)

\section{FORBS}

Clover

(Trifolium spp.)

DANDELION

(Taraxacum offincinale)

WILD STAWBERRY

(Fragaria virginiana)

Grasses

Creeping Red Fescue

(Festuca rubra)

Тімотну

(Phleum pratense)

KENTUCKY BLUEGRASS

(Poa pratensis)

HAIRY WILD RYE

(Elymus innovatus)

CRESTED WHEAT GRASS

(Agropyron pectiniforme)

MEAN RANGE CONST.

1

100

100

6

100

4

100

2

100

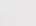$$
-
$$$$
100
$$

100$$
22-\quad 100
$$$$
3 \quad 100
$$

00

100

00

$1 \quad-\quad 100$

\section{ENVIRONMENTAL VARIABLES}

Moisture Regime (MEAN):

Submesic

NUTRIENT REgIME (MEAN): Medium

ELEVATION:

$600 \mathrm{M}$

Soll Drainage (mean): Well

Plant Composition: TAME or Modified TAME

Desirable Species Shift Score: 0

\section{FORAGE PRODUCTION(KG/HA)}

$$
\text { Total } 1000
$$

ECOLOGICALLY SUSTAINABLE STOCKING RATE

$$
\begin{gathered}
2.02 \mathrm{ha} / \mathrm{AUM}(4.05-0.51) \\
0.2 \mathrm{AUM} / \mathrm{ac}(0.1-0.3)
\end{gathered}
$$




\section{DMB23. Aw-Pb/Rose/Hairy wild rye \\ (Populus tremuloides-P. balsamifera/Rosa acicularis/Elymus innovatus)}

$\mathbf{n = 1}$ This community represents old pastures on dry sandy sites that were cleared of trees and aerial seeded with brome, timothy, crested wheat grass and creeping red fescue in the 1980's near St. Paul. In the absence of disturbance these sites have been slowly encroached by trees and the understory has been invaded by hairy wild rye. These sites are moderately productive and are easily accessible to livestock.

\section{Plant Composition Canopy Cover (\%)}

TrEes

ASPEN

(Populus tremuloides)

BALSAM POPLAR

(Populus balsamifera)

15

35

\section{SHRUBS}

PRICKLY ROSE

(Rosa acicularis)

WILLOW

(Salix bebbiana)

SNOWBERRY

(Symphoricarpos

occidentalis)

\section{FORBS}

Clover

(Trifolium spp.)

DANDELION

(Taraxacum offincinale)

WILD STAWBERRY

(Fragaria virginiana)

\section{Grasses}

Creeping Red Fescue

(Festuca rubra)

$$
\text { MEAN RANGE CONST. }
$$

$15-$

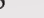

SLENDER WHEAT GRASS

(Agropyron trachycaulum)

KENTUCKY BLUEGRASS

(Poa pratensis)

HAIRY WILD RYE

(Elymus innovatus)

CRESTED WHEAT GRASS

(Agropyron pectiniforme)
100

100

100

$24 \quad 100$

100
100

100

\section{ENVIRONMENTAL VARIABLES}

MOISTURE REGIME (MEAN):

SUBMESIC

NUTRIENT REgIME (MEAN):

Medium

ELEVATION:

$600 \mathrm{M}$

SoIl Drainage (MEAN): Well

Plant Composition: TAME or Modified TAme

Desirable Species Shift Score: 0

\section{FORAGE PRODUCTION(KG/HA)}

TOTAL 1000

100

100

ECOLOGICALLY SUSTAINABLE STOCKING RATE

$2.02 \mathrm{ha} / \mathrm{AUM}(4.05-0.51)$

0.2 AUM/ac (0.1-0.3) 


\section{DMB24. Willow/Timothy \\ (Salix spp./Phleum pratense)}

$\mathbf{n}=\mathbf{2}$ This community represents invasion of shrubs and trees onto tame pasture on moister sites. Willow favours growing on these moist, richer sites and will often invade off the edges of the pasture. Burning, cultivation and spraying with herbicide are all options that can be considered in order to control shrub regrowth.

\section{Plant COMPOSITION Canopy Cover(\%)}

\section{SHRUBS}

WILLOW

(Salix bebbiana)

FORBS

Clover

(Trifolium spp.)

DANDELION

(Taraxacum offincinale)

WILD STAWBERRY

(Fragaria virginiana)

HoRSETAIL

(Equisetum arvense)

\section{Grasses}

TIMOTHY

(Phleum pratense)

SEDGE

(Carex spp.)

KENTUCKY BLUEGRASS

(Poa pratensis)

Sмоотн вROME

(Bromus inermis)
19

$8-30$

100

\section{MEAN RANGE CONST.}

$27 \quad 4-49$

6

$0-12$

$1 \quad 0-2$

50

45

43-46

100

$5 \quad 0-9 \quad 50$

$1 \quad 0-1 \quad 50$

$2 \quad 0-3 \quad 50$

\section{ENVIRONMENTAL VARIABLES}

Moisture REgIME (MEAN):

SUBHYGRIC

Nutrient REgIME (MEAN):

PERMESOTROPHIC

ELEVATION:

$600 \mathrm{M}$

SoIl DRAINAGe (MEAN):

WELL

DESIRABLE SPECIES SHIFT SCORE: 8

\section{FORAGE PRODUCTION(KG/HA)}

TotAL 2500

ECOLOGICALLY SUSTAINABLE STOCKING RATE

$1.01 \mathrm{ha} / \mathrm{AUM}(1.35-0.81)$

$0.4 \mathrm{AUM} / \mathrm{ac}(0.3-0.5)$ 


\section{DRY MIXEDWOOD SUBREGION \\ DECIDUOUS FOREST COMMUNITY TYPES}

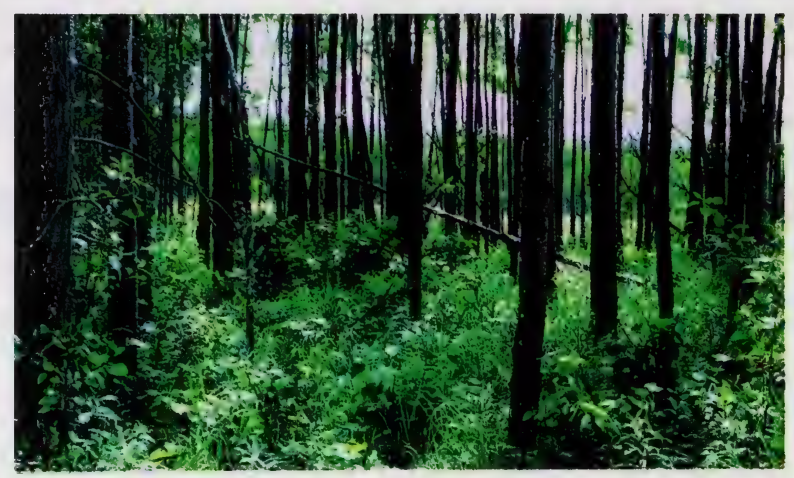

Photo 4. Aw/Rose/Tall forb community type in the Dry Mixedwood subregion

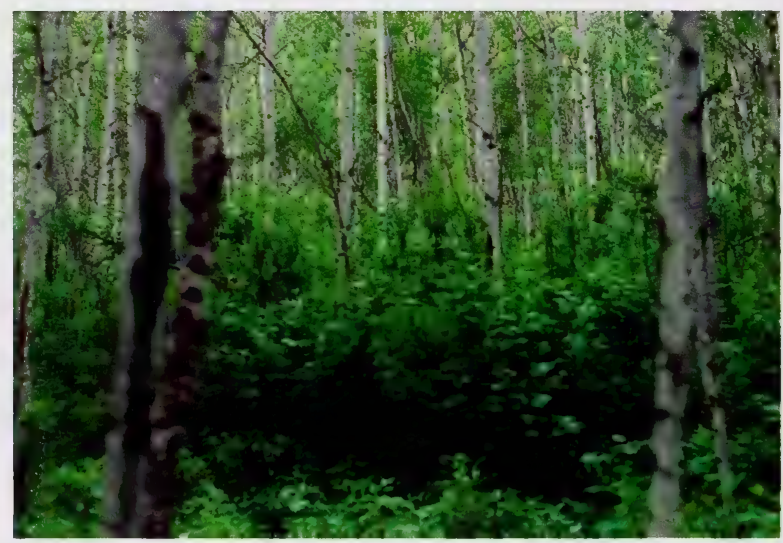

Photo 5. Aw/Hazelnut community is very common in the eastern ecodistricts of the Dry Mixedwood subregion. 


\section{DECIDUOUS FOREST COMMUNITIES}

All of the deciduous stands sampled in the Dry Mixedwood subregion were dominated by aspen and balsam poplar and had a significant rose understory. In both Brierley et al. (1985) and Beckingham's (1993) deciduous classifications in the same subregion rose was the dominant or codominant understory shrub species in nearly every aspen-dominated community type. In Beckingham's classification rose was present in 205 of the 209 aspen-dominated stands. Rose is well adapted to a wide variety of site conditions with a moderate supply of nutrients. The moisture regime can vary from submesic to subhygric and the sites can be well to imperfectly drained.

It appears the secondary forb and shrub species in association with rose characterize the ecological conditions of aspen forest types in the Dry Mixedwood subregion. Indeed, many of the deciduous types in Beckingham's classification were based on the secondary shrub species.

In the Dry Mixedwood 22 deciduous community types were described. The Aw/Blueberry type is found on well-drained, sandy sites in association with jack pine stands and the Aw/Dwarf bilberry/Bearberry/Mountain ricegrass community is found on slightly moister sites with loamy sand textures. The Aspen/Alder type is found on moist, moderately drained sites at higher elevations and the Aspen/Rose(Aw/Rose/Tall forb, Aw/Rose/Low forb, Aw/Rose-Hazelnut, Aw/Buffaloberry-Rose and Aw/Saskatoon-Rose) site types are moderately well-drained, with mesic moisture and mesotrophic nutrient regimes. Beckingham (1993), felt the Aspen/Buffaloberry type occurred on somewhat nutrient-poor soils. The Aspen/Rose/Tall and Low forb community types occupy similar site conditions. The difference between these two types may be related to grazing pressure. The Aspen/Rose/Low forb type has a low total cover of forbs (48\%), whereas the Aspen/Rose/Tall forb type has a high total cover of forbs (81\%). The increased grazing pressure in the Aspen/Rose/Low forb type may have caused a reduction in forb cover. The Aspen/Hazelnut type is found on mesic, well-drained sites and appears to be the reference deciduous type for this subregion, particularly in the more eastern ecodistricts. The hazelnut-dominated community types were very common within the eastern ecodistricts in the southern part of the subregion (St. Paul, Bonnyville, Smoky Lake). The presence of hazelnut appears to be indicative of warmer sites (Beckingham 1993) and have some fire history (Downing and Karpuk 1992).

A number of balsam poplar-dominated community types were described in the western and eastern ecodistricts. These communities are typical of forests situated along the flood plains of rivers and seepage areas in lower slope positions. The Balsam poplar-Aspen/Horsetail and Balsam poplar-Aspen/Willow type are found on moist poorly drained sites adjacent to some willow shrublands.

The position sequence of the dominant community types in the d.1. ecological site phase is shown in figure 7. 


\section{Ecological site phase: d.1 low bush cranberry - Aw}

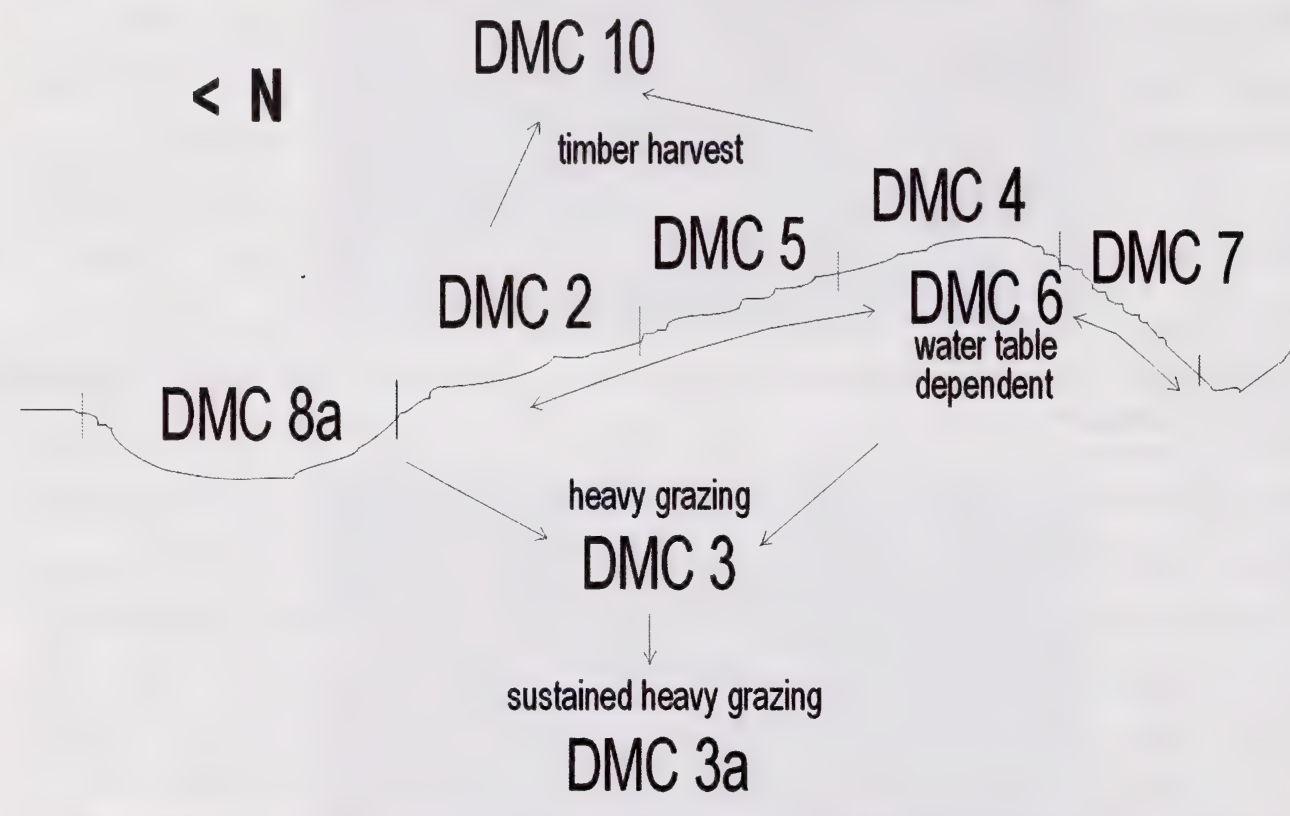

NOTE: DMC 5 may not be present in eastern areas of the Dry Mixedwood subregion.

Figure 7. Overview of deciduous communities in the Dry Mixedwood subregion. 


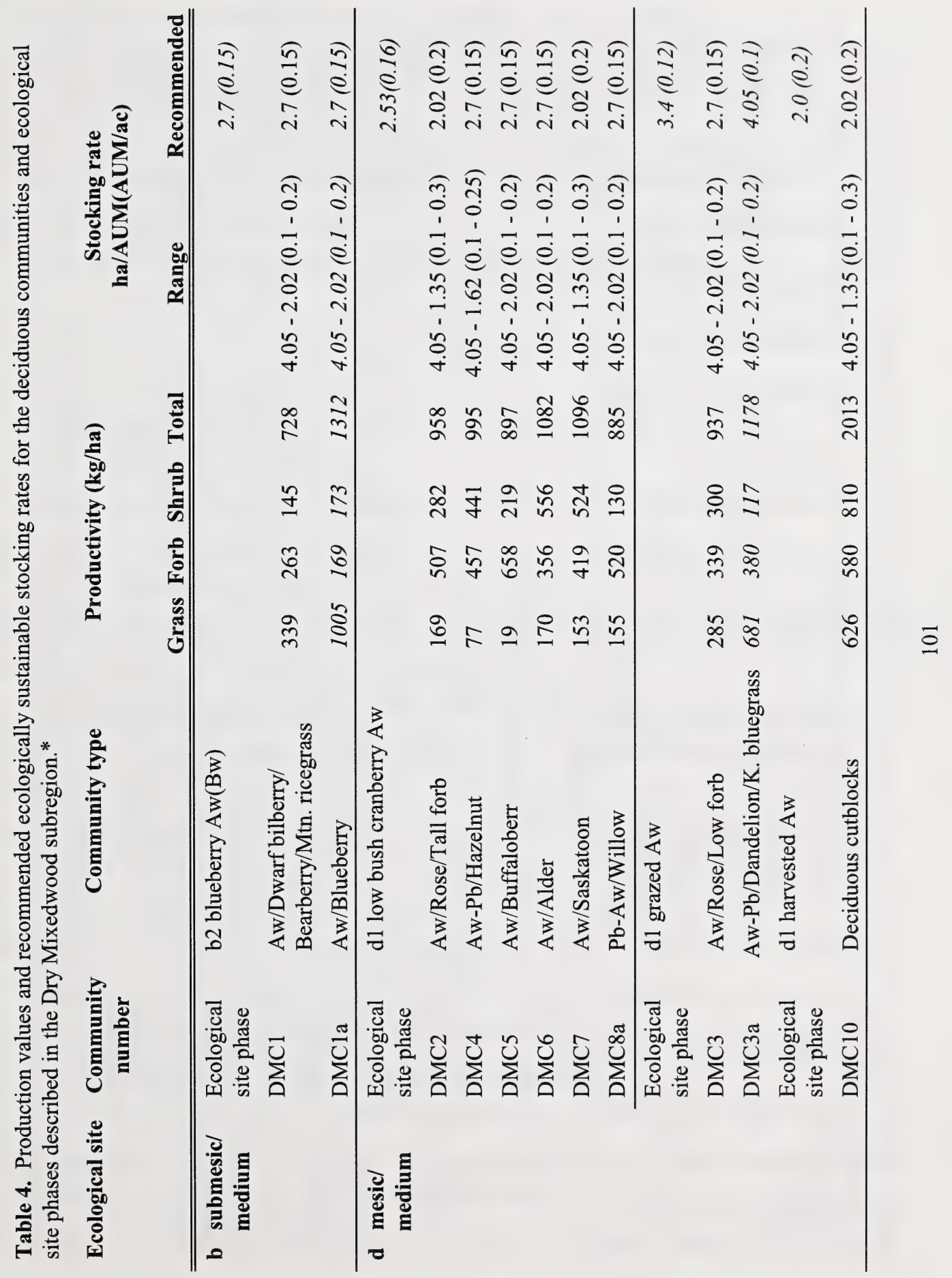




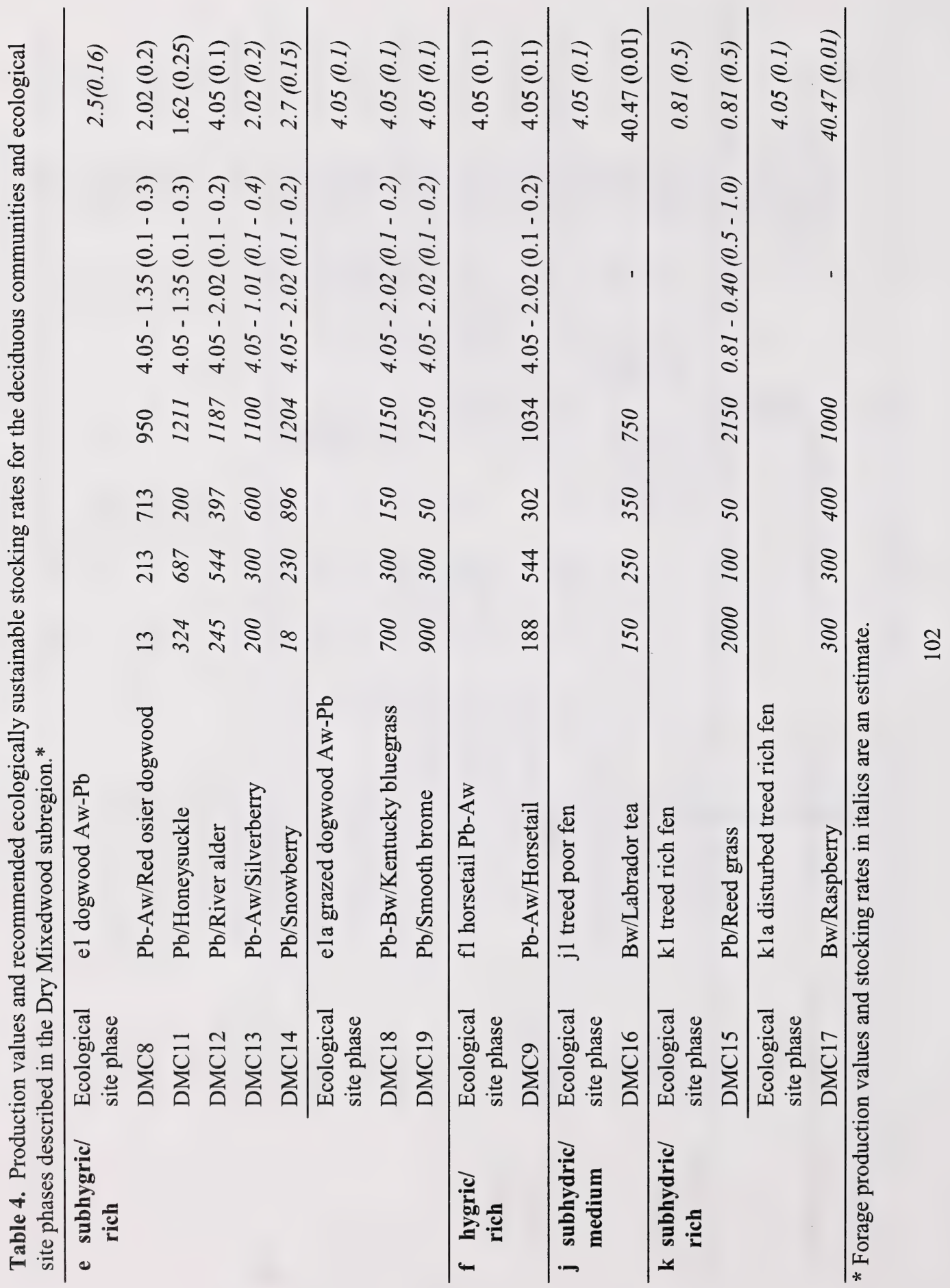


1. Sites where plant community succession is in the early stages (i.e. recently reset by logging or fire).

DMC10 Deciduous cutblocks and unseeded clearings

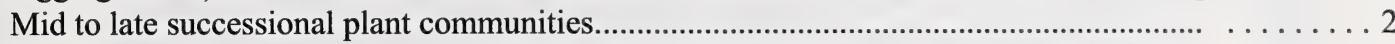

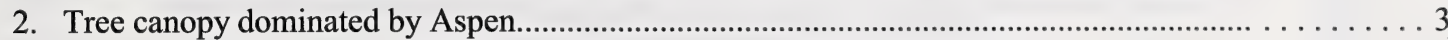

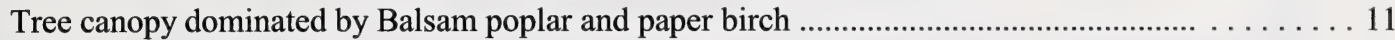

3. Dry sites with sandy soil texture, blueberry and bearberry dominate understory................... . . 4

Sites with mesic or better moisture, blueberry or bearberry may be present but do not

dominate the understory

4. Sandy sites dominated by blueberry.

DMC1a Aw/Blueberry

Loamy sand sites dominated by dwarf bilberry, bearberry and Mtn. ricegrass.

DMC1 Aw/D.bilberry/Bearberry/Mtn. ricegrass

5. Heavily grazed sites dominated by dandelion, Kentucky bluegrass or clover.

.DMC3a Aw/Dandelion/Kentucky bluegrass

Moderately or lightly grazed sites dominated by shrubs.

6. Beaked hazelnut dominates the understory

Sites dominated by other shrubs

7. Alder dominates the understory. .DMC4 Aw-Pb/Hazelnut

Sites dominated by other shrubs

.DMC6 Aw/Alder

8. Slope communities dominated by saskatoon. Sites dominated by other shrubs

DMC7 Aw/Saskatoon

. Buffaloberry dominates the understory

Rose and forb dominated understory.

DMC5 Aw/Buffaloberry

10. Tall forb dominated (fireweed, showy aster, peavine, wild sarsaparilla)....DMC2 Aw/Rose/Tall forb Low forb dominated (bunchberry, twinflower, strawberry, wintergreen)...DMC3 Aw/Rose/Low forb

11. Heavily grazed birch or balsam poplar dominated sites................................................ 12

Moderately or lightly grazed birch or balsam poplar dominated sites.............................. 13

12. Smooth brome dominates understory.

DMC19 Pb/Smooth brome

Kentucky bluegrass and dandelion dominated.

DMC18 Pb-Bw/K. bluegrass

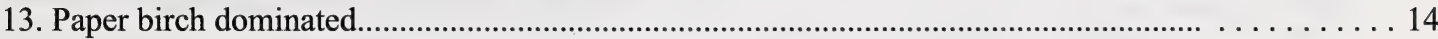

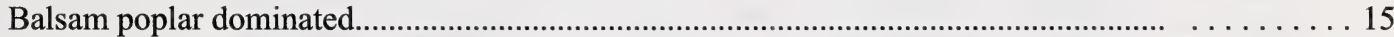

14. Boggy area that has recently burned

DMC16 Bw/Labrador tea

Wet sites with recent beaver activity.

DMC17 Bw/Raspberry

15. Very wet site, grass meadows invaded by balsam poplar.............

Upland sites dominated by shrubs or horsetail

16. Riverine forests dominated by dogwood in understory...DMC8 Pb-Aw/Red osier dogwood

Sites dominated by other shrubs or horsetail in the understory.

17. Willow dominates the understory.

DMC8a Pb-Aw/Willow

Sites dominated by other shrubs or horsetail in the understory.

18. Riverine forest dominated by river alder.

.DMC12 Pb/River alder

Sites dominated by other shrubs or horsetail in the understory.

19. Very moist sites dominated by horsetail in the understory.........DMC9 Pb-Aw/Horsetail

Understory dominated by shrubs.

20. Honeysuckle present as a co-dominant shrub on rich seepage sites....DMC11 Pb/Honeysuckle

Snowberry or silverberry are dominant is the understory.

21. Snowberry dominates the understory.

Silverberry dominates the understory.

DMC14 Pb/Snowberry

.DMC13 Pb-Aw/Silverberry 5 


\section{DMC1. Aw/Dwarf bilberry/Bearberry/Mountain ricegrass \\ (Populus tremuloides/Vaccinium caespitosum/Arctostaphylos uva-ursi/Oryzopsis asperifolia)}

$\mathbf{n}=26$ This community type is found on dry, well-drained, loamy-sand sites and is part of the blueberry ecosite outlined by Beckingham and Archibald (1996). The canopy cover of aspen is open allowing for easy access by livestock, but the dry site conditions and poorer nutrient status limit the amount of regrowth after grazing. If this community type is managed for one rotation a year, it can contribute significantly to the overall carrying capacity of a lease.

Plant Composition canopy Cover(\%)

MEAN RANGE CONST.

TREES

Trembling Aspen
(Populus tremuloides)

WHITE SPRUCE

(Picea glauca)

43

$20-75$

$2 \quad 0-15$

42

\section{SHRUBS}

PRICKLY ROSE

(Rosa acicularis)

SASKATOON

(Amelanchier alnifolia)

BLUEBERRY

(Vaccinium myrtillus)

DWARF BILBERRY

(Vaccinium caespitosum)
NORTHERN RICEGRASS

(Oryzopsis pungens)

\section{ENVIRONMENTAL VARIABLES}

Moisture Regime:

SUBMESIC

NUTRIENT REgIME:

POOR

ELEVATION:

$$
455 \mathrm{M}
$$

SOIL DRAINAGE:

WELL

Ecological Status Score: 18

\section{FORAGE PRODUCTION(KG/HA)}

\section{BEARBERRY}

(Arctostaphylos uva-ursi)

TWINFLOWER

$0-36 \quad 75$

(Linnaea borealis)

7. $0-36$

LINDLEY'S ASTER

(Aster ciliolatus)

$0-22 \quad 88$

WILD LILY OF THE VALLEY

(Maianthemum canadense) 5

YELLOW PEAVINE

$\begin{array}{llll}\text { (Lathyrus ochroleucus) } & 7 & 3-31 & 100\end{array}$

STRAWBERRY

$\begin{array}{llll}\text { (Fragaria virginiana) } & 5 & 0-12 & 96\end{array}$

GRASSES

Mountain Rice Grass

(Oryzopsis asperfolia)

HAIRY WILD RYE

(Elymus innovatus)

$0-6$

PURPLE OAT GRASS

(Schizachne purpurascens) 3 $\begin{array}{ll}\text { GRASS } & 339(166-442) \\ \text { FORBS } & 263(64-610) \\ \text { SHRUBS } & 145(56-266) \\ \text { TOTAL } & 728(230-1284)\end{array}$

ECOLOGICALLY SUSTAINABLE STOCKING RATE $2.7 \mathrm{ha} / \mathrm{AUM}$ (4.05-2.02)

$0.15 \mathrm{AUM} / \mathrm{ac}(0.1-0.2)$ 


\section{DMC1a. Aw/Blueberry (Populus tremuloides/Vaccinium myrtillus)}

$\mathbf{n = 1}$ This community type is found on dry, well-drained, sandy sites interspersed with stands of jack pine and is part of the blueberry ecosite outlined by Beckingham and Archibald (1996). The canopy cover of aspen is open allowing for easy access by livestock, but the dry site conditions and poorer nutrient status limit the amount of regrowth after grazing. If this community type is managed for one rotation a year, it can contribute significantly to the overall carrying capacity of a lease.

\section{Plant Composition Canopy Cover $(\%)$}

\section{TREES}

Trembling Aspen

(Populus tremuloides)

35

100

\section{SHRUBS}

PRICKLY ROSE

(Rosa acicularis)

LOW BUSH CRANBERRY

(Viburnum edule)

BLUEBERRY

(Vaccinium myrtillus)

MEAN RANGE CONST.

\section{FORBS}

BEARBERRY

(Arctostaphylos uva-ursi)

TWINFLOWER

(Linnaea borealis)

STRAWBERRY

(Fragaria virginiana)

WILD LILY OF THE VALLEY

(Maianthemum canadense) 15

WILD SARSAPARILLA

(Aralia nudicaulis)

\section{7}

100

100

100

\section{Grasses}

HAIRY WILD RYE

(Elymus innovatus)

NORTHERN RICEGRASS

(Oryzopsis pungens)

5

100

100

100

100

100

\section{LICHEN}

REINDEER LICHEN

(Cladina mitis)
100

100

\section{ENVIRONMENTAL VARIABLES}

Moisture Regime:

SUBMESIC-SUBXERIC

NUTRIENT REGIME:

POOR

EleVATION:

$455 \mathrm{M}$

SOIL DRAINAGE:

WELL

Ecological Status Score: 18

FORAGE PRODUCTION(KG/HA)

Total $\quad 750 *$ Estimate

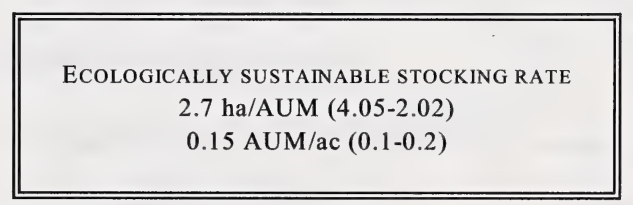




\section{DMC2. Aw/Rose/Tall forb \\ (Populus tremuloides/Rosa acicularis/Tall forbs)}

$\mathbf{n}=71$ This community type is part of the low bush cranberry ecosite outlined by Beckingham and Archibald (1996). This community type is also very similar to the Aspen/Rose/Low forb community type, but the cover of forbs is much higher. This appears to be related to the grazing pressure. The higher the grazing pressure on the Aw/Rose/Tall forb community type appears to cause a reduction in the cover of tall growing forbs (wild sarsaparilla, fireweed, peavine, showy aster) and favours the growth of low growing forbs (bunchberry, dewberry, wintergreen, strawberry). This community type is providing a moderate amount of forage for domestic livestock.

\section{Plant Composition Canopy Cover $(\%)$}

\section{TREES}

Trembling Aspen

$\begin{array}{llll}\text { (Populus tremuloides) } & 51 & 15-70 & 100\end{array}$

BALSAM POPLAR

(Populus balsamifera)

$4 \quad 0-10$

58

\section{SHRUBS}

HAZELNUT

(Corylus cornuta)

WILD RED RASPBERRY

(Rubus idaeus)

(Lonicera involucrata)

PRICKLY ROSE

(Rosa acicularis)

LOW BUSH CRANBERRY

(Viburnum edule)
BRACTED HONEYSUCKLE

Grasses

MARSH REED GRASS

(Calamagrostis canadensis)5 $\quad 0-65 \quad 93$

HAIRY WILD RYE

(Elymus innovatus) $\quad 3 \quad 0-30 \quad 70$

\section{ENVIRONMENTAL VARIABLES}

Moisture REgIME:

MESIC TO SUBHYGRIC

NUtRIENT REGIME:

MEDIUM TO RICH

ELEVATION:

455-606(496) M

Percent Slope Gradient:

$0-25(5)$

SOIL DRAINAGE:

WELL TO MODERATELY WELL

Ecological Status Score: 18

\section{FORAGE PRODUCTION(KG/HA)}

\section{FIREWEED}

(Epilobium angustifolium) $3 \quad 0-7$

DEWBERRY OR RUNNING RASPBERRY

(Rubus pubescens) $\quad 4 \quad 0-7$

Palmate-leaved Coltsfoot

(Petasites palmatus)

$2 \quad 0-10 \quad 78$

WILD STRAWBERRY

$\begin{array}{llll}\text { (Fragaria virginiana) } & 3 & 0-4 & 87\end{array}$

LINDLEY'S ASTER

(Aster ciliolatus)

YELLOW PEAVINE

(Lathyrus ochroleucus)

WILD SARSAPARILLA

(Aralia nudicaulis)

$\begin{array}{lll}3 & 0-4 & 87 \\ 1 & 0-4 & 76 \\ 7 & 0-27 & 96 \\ 11 & 0-57 & 79\end{array}$
GRASS 169(0-444)
FORBS 507(72-988)
SHRUBS 282(118-378)
TOTAL 958(624-1810)

ECOLOGICALLY SUSTAINABLE STOCKING RATE

$$
2.02 \mathrm{ha} / \mathrm{AUM}(4.05-1.35)
$$$$
0.2 \mathrm{AUM} / \mathrm{ac}(0.1-0.3)
$$ 


\section{DMC3. Aw/Rose/Low forb \\ (Populus tremuloides/Rosa acicularis/Low forbs)}

$\mathbf{n}=\mathbf{6 0}$ This community type is part of the low bush cranberry ecosite described by Beckingham and Archibald (1996) and is very similar to the Aw/Rose/Tall forb community type previously described. The difference in the community types appears to be related to the grazing pressure. The higher the grazing pressure on the Aw/Rose/Tall forb community type appears to cause a reduction in the cover of tall growing forbs (wild sarsaparilla, fireweed, peavine, showy aster) and favours the growth of low growing forbs (bunchberry, dewberry, wintergreen, strawberry). This community type is providing a moderate amount of forage for domestic livestock.

\section{Plant Composition Canopy Cover(\%)}

MEAN RANGE CONST.

TreEs

Trembling Aspen

(Populus tremuloides)

BALSAM POPLAR

(Populus balsamifera)

46

$15-85$

$3 \quad 0-15$

100

33

\section{SHRUBS}

WILLOW SPP.

(Salix spp.)

SASKATOON

(Amelanchier alnifolia)

WILD RED RASPBERRY

(Rubus idaeus)

SNOWBERRY

(Symphoricarpos

occidentalis)

PRICKLY Rose

(Rosa acicularis)

$\begin{array}{lll}2 & 0-20 & 36 \\ 1 & 0-11 & 48 \\ 5 & 0-20 & 93\end{array}$

4

$13 \quad 1-55$

100

\section{FORBS}

FIREWEED

(Epilobium angustifolium) $1 \quad 0-1$

DEWBERRY OR RUNNING RASPBERRY

(Rubus pubescens)
PALMATE-LEAVED COLTSFOOT

(Petasites palmatus) 1

WILD STRAWBERRY

(Fragaria virginiana)

LINDLEY'S ASTER

(Aster ciliolatus)

BUNCHBERRY

(Cornus canadensis)

WILD SARSAPARILLA

(Aralia nudicaulis)

WINTERGREEN

(Pyrola asarifolia)

$\begin{array}{lll}1 & 0-30 & 53 \\ 3 & 0-12 & 92 \\ 2 & 0-12 & 82 \\ 5 & 0-22 & 83 \\ 1 & 0-9 & 38 \\ 3 & 0-20 & 85\end{array}$

\section{Grasses}

Marsh ReEd Grass

(Calamagrostis canadensis) $2 \quad 0-20 \quad 77$

SLENDER WHEAT GRASS

$\begin{array}{llll}\text { (Agropyron trachycaulum) } & 2 & 0-40 & 33\end{array}$

HAIRY WILD RYE

$\begin{array}{llll}\text { (Elymus innovatus) } & 3 & 0-22 & 73\end{array}$

\section{ENVIRONMENTAL VARIABLES}

MoIsture Regime:

Mesic to Subhygric

NUtRIENT REgime:

MEDIUM TO RICH

Elevation: 455-697(524) M

Percent Slope Gradient: 0 - 5

Soll Drainage:

Well to Moderately WELL

ECOlogical Status Score: 12

\section{FORAGE PRODUCTION(KG/HA)}
GRASS 285(12-996)
FORBS 339(90-842)
SHRUBS 300(0-896)
Total 937(414-2074)

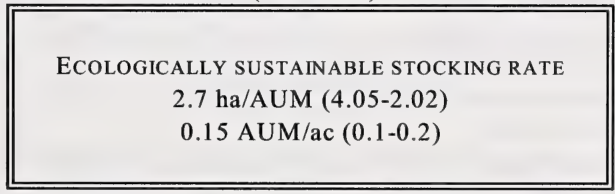




\section{DMC3a. Aw-Pb/Dandelion/Kentucky bluegrass (Populus tremuloides-P. balsamifera/Taraxacum officinale/Poa pratensis )}

$\mathbf{n}=\mathbf{6}$ This community represents the $\mathrm{Aw}$ or $\mathrm{Pb} / \mathrm{Rose} / \mathrm{Tall}$ forb community that has received prolonged heavy grazing. This community type often occurs in relatively small isolated patches created by intensive grazing adjacent to water, salt or temporary holding areas. The species richness and diversity of native shrubs, forbs, and grass is reduced and replaced by grazing resistant clover, dandelion and Kentucky bluegrass.

\section{Plant Composition Canopy Cover $(\%)$}

TREES

MEAN RANGE CONST.

TREMBLING ASPEN

$\begin{array}{llll}\text { (Populus tremuloides) } & 36 & 20-50 & 100\end{array}$

BALSAM POPLAR

(Populus balsamifera)

$32 \quad 20-40$

100

\section{SHRUBS}

WILLOW SPP.

(Salix spp.)

WILD RED RASPBERRY

(Rubus idaeus)

SNOWBERRY

(Symphoricarpos

occidentalis)

Prickly Rose

(Rosa acicularis)

$\begin{array}{lll}2 & 1-3 & 100 \\ 4 & 0-10 & 80\end{array}$

$\begin{array}{lll}7 & 0-20 & 80\end{array}$

$15 \quad 3-30 \quad 100$

\section{FORBS}

Clover

$\begin{array}{llll}\text { (Trifolium spp.) } & 10 & 0-20 & 80\end{array}$

DEWBERRY OR RUNNING RASPBERRY

$\begin{array}{llll}\text { (Rubus pubescens) } & 2 & 0-10 & 83 \\ \text { DANDELION } & & \end{array}$

(Taraxacum officinale) $\quad 4 \quad 1-10 \quad 100$

WILD STRAWBERRY

$\begin{array}{llll}\text { (Fragaria virginiana) } & 3 & 1-3 & 100\end{array}$

SHOWY ASTER

(Aster conspicuus)

BUNCHBERRY

(Cornus canadensis)

WILD SARSAPARILLA

(Aralia nudicaulis)

WINTERGREEN

(Pyrola asarifolia)

\section{Grasses}

MARSh ReEd Grass

(Calamagrostis canadensis) $1 \quad 0-3 \quad 67$

KENTUCKY BLUEGRASS

$\begin{array}{llll}\text { (Poa pratensis) } & 4 & 0-10 & 83\end{array}$

HAIRY WILD RYE

(Elymus innovatus) $\quad 2 \quad 0-10 \quad 50$

\section{ENVIRONMENTAL VARIABLES}

MOISTURE REGIME:

MESIC TO SUBHYGRIC

NUTRIENT REgIME:

Mesotrophic to Permesotrophic

ELEVATION:

455-697(524) M

Percent Slope Gradient:

$$
0-5
$$

Soll Drainage:

Well to Moderately Well

Ecological Status Score: 6-0

\section{FORAGE PRODUCTION(KG/HA)}

Total $1178 *$ Estimate

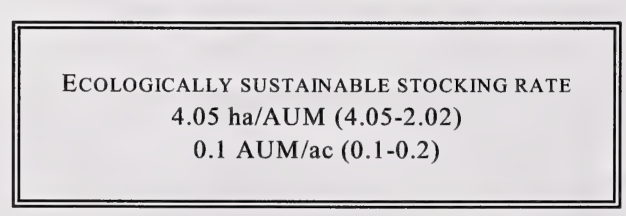




\section{DMC4. Aw-Pb/Hazelnut \\ (Populus tremuloides-P. balsamifera/Corylus cornuta)}

$\mathbf{n}=45$ Beaked hazelnut is a common component of many of the deciduous stands in both the western and eastern ecodistricts of the Dry Mixedwood subregion. The presence of hazelnut appears to be indicative of warmer sites and have some fire history (Downing and Karpuk 1992). This community tends to occur on moderately to well drained, fine-textured and gently sloping till deposits. The total forage productivity of this community type is only moderate, but the majority of the production is coming from hazelnut, which is largely unpalatable to livestock at proper stocking levels. The high cover of hazelnut also restricts access to livestock, limiting the forage availability.

\section{Plant Composition Canopy Cover(\%)}

\section{TREES}

TREMBLING ASPEN

\section{(Populus tremuloides)}

BALSAM POPLAR

(Populus balsamifera)

PAPER BIRCH

(Betula papyrifera)

\section{SHRUBS}

HAZELNUT

(Corylus cornuta)

PRICKLY Rose

(Rosa acicularis)

SNOWBERRY

(Symphoricarpos

occidentalis, albus)

SASKATOON

(Amelanchier alnifolia)

LOW BUSH CRANBERRY

(Viburnum edule)

MEAN RANGE CONST.

$\begin{array}{lll}38 & 3-75 & 100 \\ 5 & 0-60 & 38 \\ 2 & 0-70 & 4\end{array}$

\section{FORBS}

LINDLEY'S ASTER

(Aster ciliolatus)

DEWBERRY OR RUNNING RASPBERRY

(Rubus pubescens)

PEAVINE

(Lathyrus ochroleucus)

AMERICAN VETCH

(Vicia americana)

BUNCHBERRY

(Cornus canadensis)

WILD SARSAPARILLA

(Aralia nudicaulis)

$\begin{array}{lll}39 & 12-70 & 100 \\ 9 & 0-25 & 82 \\ 4 & 4-10 & 100 \\ 4 & 0-18 & 89 \\ 3 & 0-16 & 71\end{array}$

\section{Grasses}

MARSh REED GRASS

(Calamagrostis canadensis) $4 \quad 0-10$

87

\section{ENVIRONMENTAL VARIABLES}

\section{Moisture Regime:}

MESIC TO SUBHYGRIC

NUTRIENT REGIME:

MEDIUM TO RICH

ELEVATION:

$455 \mathrm{M}$

Percent Slope Gradient:

$0-15 \%$

SOIL DRAINAGE:

WELl TO MOdERATELY WELL

ECological Status Score: 18

\section{FORAGE PRODUCTION(KG/HA)}
GRASS $77(2-200)$
FORBS 457(398-520)
SHRUBS 441(348-522)
TотAL 995(830-1180)

ECOLOGICALLY SUSTAINABLE STOCKING RATE

$2.7 \mathrm{ha} / \mathrm{AUM}$ (4.05-1.62)

$0.15 \mathrm{AUM} / \mathrm{ac}(0.1-0.25)$ 


\section{DMC5. Aw/Buffaloberry \\ (Populus tremuloides/Shepherdia canadensis)}

$\mathbf{n}=\mathbf{5}$ This community type was found on mesic sites at higher elevations in the Saddle and Birch hills. Beckingham (1993) felt the Aw/Buffaloberry type was slightly drier and had a slightly poorer nutrient regime than the model Aw/Rose community types. This type is providing a moderate amount of forage for domestic livestock, but the drier site conditions and poorer nutrient status will limit regrowth after grazing. Buffaloberry the predominant shrub species in this community type, is generally unpalatable to livestock.

\section{Plant Composition Canopy Cover(\%)}

\section{MEAN RANGE CONST.}

TREES

TREMBLING AsPen

(Populus tremuloides)

$52 \quad 30-85 \quad 100$

\section{SHRUBS}

BUFFALOBERRY

$\begin{array}{lccc}\begin{array}{l}\text { (Shepherdia canadensis) } \\ \text { WILD RED RASPBERRY }\end{array} & 25 & 11-38 & 100 \\ \begin{array}{l}\text { (Rubus idaeus) } \\ \text { BRACTED HONEYSUCKLE }\end{array} & 3 & 0-8 & 60 \\ \begin{array}{l}\text { (Lonicera involucrata) } \\ \text { PRICKLY RoSE }\end{array} & 1 & 0-2 & 20 \\ \begin{array}{l}\text { (Rosa acicularis) } \\ \text { Low BUSH CRANBERRY } \\ \text { (Viburnum edule) }\end{array} & 8 & 2-17 & 100\end{array}$

BUNCHBERRY

(Cornus canadensis) $\quad 8 \quad 0-21$

DEWBERRY OR RUNNING RASPBERY

(Rubus pubescens) $\quad 2 \quad 0-9$

YELLOW PEAVINE

$\begin{array}{llll}\text { (Lathyrus ochroleucus) } & 8 & 1-18 & 100\end{array}$

TWINFLOWER

(Linnaea borealis)

$3 \quad 0-8$

60

Grasses

MARSh ReEd Grass

(Calamagrostis canadensis) $2 \quad 1-7 \quad 80$

HAIRY WILD RYE

(Elymus innovatus)

$5 \quad 1-15$

100

\section{ENVIRONMENTAL VARIABLES}

Moisture Regime:

MESIC

NUTRIENT REgIME:

MEDIUM

ELEVATION:

455-758(556) M

Percent Slope Gradient:

$$
0-15
$$

SoIL DRAINAGE:

WELL

Ecological Status Score: 18

FORAGE PRODUCTION(KG/HA)
GRASS 112
FORBS 304
SHRUBS 346
TOTAL 713

ECOLOGICALLY SUSTAINABLE STOCKING RATE

$2.7 \mathrm{ha} / \mathrm{AUM}(4.05-2.02)$

0.15 AUM/ac (0.1-0.2) 


\section{DMC6. Aw/Alder \\ (Populus tremuloides/Alnus crispa)}

$\mathbf{n = 7}$ This community type was described at a higher elevation $(600 \mathrm{~m})$ in the Dry Mixedwood subregion. Brierly et al. (1985) and Beckingham (1993) both described aspen-alder communities at higher elevations ( $>600 \mathrm{~m})$. It appears that the presence of alder may indicate a transition from the Dry Mixedwood into the Lower Foothills subregion.

This community type is providing a moderate amount of forage for domestic livestock, but the high cover of alder will limit access

\section{Plant Composition Canopy Cover $(\%)$} MEAN RANGE CONST.

\section{TREES}

BALSAM POPLAR

(Populus balsamifera) $\quad 5 \quad 1-10 \quad 100$

Trembling AsPen

(Populus tremuloides)

$45 \quad 25-60$

100

\section{SHRUBS}

PRICKLY Rose

(Rosa acicularis)

WILD RED RASPBERRY

(Rubus idaeus)

LOW BUSH CRANBERRY

(Viburnum edule)

GREEN ALDER

(Alnus crispa)

\section{FORBS}

Cream-coloured Vetchling

(Lathyrus ochroleucus) 4

BUNCHBERRY

(Cornus canadensis) 12

STRAWBERRY

(Fragaria virginiana)

WILD SARSAPARILLA

(Aralia nudicaulis)

$4 \quad 0-6$

83

$12 \quad 0-30$

$2 \quad 1-3$

100

Grasses

MARSH REED GRASS

(Calamagrostis canadensis) 21

$0-65$

83

SLENDER WheAT GRASS

(Agropyron trachycaulum) 2
$0-5$

50

\section{ENVIRONMENTAL VARIABLES}

Moisture Regime:

MESIC

Nutrient REgIME:

MEDIUM

Elevation:

$600 \mathrm{M}$

Percent Slope Gradient:

$$
5 \%
$$

SoIL DRAINAGE:

WELL

Ecological Status Score: 18

\section{FORAGE PRODUCTION(KG/HA)}
Grass 170
FORBS 356
SHRUBS 556
TOTAL 1082

ECOLOGICALLY SUSTAINABLE STOCKING RATE

$$
2.7 \mathrm{ha} / \mathrm{AUM}(4.05-2.02)
$$

0.15 AUM/ac (0.1-0.2) 


\section{DMC7. Aw/Saskatoon \\ (Populus tremuloides/Amelanchier alnifolia)}

$\mathbf{n}=9$ This community type is found on mesic, well drained south facing slopes that overlook rivers and creeks Generally, hazelnut, chokecherry, saskatoon and snowberry are indicative of the Dry Mixedwood subregion and are usually found associated with each other. When saskatoon predominates it usually occurs on south and west facing slopes. Saskatoon provides important browse for wild ungulates. Livestock also find saskatoon palatable and in areas where there is extensive cattle grazing this species can be heavily browsed.

\section{Plant Composition Canopy Cover(\%)}

MEAN RANGE CONST.

TREES

TREMBLING ASPEN

$\begin{array}{llll}\text { (Populus tremuloides) } & 55 & 35-70 & 100\end{array}$

BALSAM POPLAR

(Populus balsamifera)

$4 \quad 0-20$

44

\section{SHRUBS}

SASKATOON

$\begin{array}{llll}\text { (Amelanchier alnifolia) } & 21 & 15-30 & 100\end{array}$

PRICKLY Rose

(Rosa acicularis)

WILD RED RASPBERRY

(Rubus idaeus)

SNOWBERRY

(Symphoricarpos

occidentalis)

CHOKECHERRY

(Prunus virginiana)

$\begin{array}{lll}21 & 15-30 & 100 \\ 12 & 1-31 & 100 \\ 5 & 0-17 & 67\end{array}$$$
5
$$$$
0-12
$$

FORBS

YELLOW PEAVINE

(Lathyrus ochroleucus) $\quad 2 \quad 0-10 \quad 78$

STRAWBERRY

$\begin{array}{llll}\text { (Fragaria virginiana) } & 1 & 0-10 & 78\end{array}$

DEWBERRY OR RUNNING RASPBERRY

$\begin{array}{llll}\text { (Rubus pubescens) } & 2 & 0-10 & 67\end{array}$

WILD SARSAPARILLA

(Arailia nudicaulis)

$6 \quad 0-20$

89

Grasses

MARSH REED GRASS

$\begin{array}{lll}\text { (Calamagrostis canadensis) } & 3 & 1-10\end{array}$
ENVIRONMENTAL VARIABLES

MoIsture Regime:

MESIC

Nutrient REgIME:

MEDIUM

ELEVATION:

455-630 M

Percent Slope Gradient:

$$
4(3-5 \%)
$$

ASPECT:

SOUTHERLY-WESTERLY

SOIL DRAINAGE:

WELL

ECological Status Score: 18

\section{FORAGE PRODUCTION(KG/HA)}

$\begin{array}{ll}\text { GRASS } & 153(42-264) \\ \text { FORBS } & 419(250-587) \\ \text { SHRUBS } & 524(514-534) \\ \text { TOTAL } & 1096(826-1365\end{array}$

ECOLOGICALLY SUSTAINABLE STOCKING RATE

$2.02 \mathrm{ha} / \mathrm{AUM}(4.05-1.35)$

$0.2 \mathrm{AUM} / \mathrm{ac}(0.1-0.3)$ 


\section{DMC8. Pb-Aw/Red osier dogwood (Populus balsamifera-P. tremuloides/Cornus stolonifera)}

$\mathbf{n = 5 1}$ This community type is typical of river floodplains throughout the Dry Mixedwood subregion. This community type tends to have a subhygric moisture and rich nutrient regime. Beckingham and Archibald (1996) found this community type on mid to lower slope topographic positions or near water courses where they recieve nutrient-rich seepage or flood waters for a portion of the growing season. This community type is one of the most productive in the Dry Mixedwood subregion, but the high cover of shrubs limits access to livestock.

\section{Plant Composition Canopy Cover (\%)} MEAN RANGE CONST.

TREES

BALSAM POPLAR

(Populus balsamifera)

$\begin{array}{lll}37 & 0-80 & 84\end{array}$

Trembling Aspen

(Populus tremuloides)

PAPER BIRCH

$20 \quad 0-60 \quad 69$

(Betula papyrifera)$$
0-50
$$$$
41
$$

\section{SHRUBS}

RED OSIER DOGWOOD
(Cornus stolonifera)

WILD RED RASPBERRY

(Rubus idaeus)

PRICKLY ROSE

(Rosa acicularis)

LOW BUSH CRANBERRY

(Viburnum edule)

\section{ForbS}

HORSETAIL

(Equisetum arvense)

WILD SARSAPARILLA

4

$0-10$

(Aralia nudicaulis)

PEAvine

(Lathyrus ochroleucus)

FIREWEED

(Epilobium angustifolium)

$\begin{array}{lll}23 & 8-70 & 100 \\ 4 & 0-18 & 60 \\ 9 & 0-18 & 78 \\ 7 & 0-30 & 78\end{array}$

7

$0-40$

80

$1 \quad 0-4$

3

61

Grasses

MARSh REED GRASS

(Calamagrostis canadensis) 4

\section{ENVIRONMENTAL VARIABLES}

MoIsture Regime:

SUBHYGRIC

NUTRIENT REGIME:

$$
\mathrm{RICH}
$$

Elevation:

455-606 M

Soll Drainage:

MODERATELY WELL

Ecological Status Score: 18

FORAGE PRODUCTION(KG/HA)
GRASS $\quad 13(0-50)$
FORBS 213(150-250)
SHRUBS 713(400-900)
TREE 13(0-50)
TotAL 950(600-1150)

ECOLOGICALLY SUSTAINABLE STOCKING RATE

$2.02 \mathrm{ha} / \mathrm{AUM}(4.05-1.35)$

0.2 AUM/ac (0.1-0.3) 


\section{DMC8a. Pb-Aw/Willow \\ (Populus balsamifera-P. tremuloides/Salix spp.)}

$\mathbf{n}=\mathbf{6}$ This community type is typical of aspen forests adjacent to sloughs and wet meadows. The edges of the sedge meadows tend to be willow dominated. This community type represents the transition from the meadow edge into the aspen and balsam poplar dominated forest. This community type is relatively moist and nutrient rich, but the high cover of willow limits the light reaching the forest floor inhibiting the growth of understory shrub, forbs and grass. As a result there is little forage for domestic livestock.

\section{Plant Composition Canopy Cover $(\%)$}

\section{TREES}

BALSAM POPLAR

(Populus balsamifera)

Trembling Aspen

(Populus tremuloides)

PAPER BIRCH

(Betula papyrifera)

\section{SHRUBS}

WILLOW SPP.

(Salix spp.)

WILD RED RASPBERRY

(Rubus idaeus)

PRICKLY ROSE

(Rosa acicularis)

MEAN RANGE CONST.

BRACTED HONEYSUCKLE

(Lonicera involcrata)

\section{FORBS}

STRAWBERRY

(Fragaria virginiana) $3 \quad 1-5$

LINDLEY'S ASTER

(Aster ciliolatus)

TALL LUNGWORT

(Mertensia paniculata)

DEWBERRY

(Rubus pubescens)

HORSETAIL

(Equisetum arvense)

$\begin{array}{lll}25 & 0-60 & 83 \\ 16 & 0-50 & 67 \\ 7 & 0-20 & 50\end{array}$

$\begin{array}{lll}27 & 20-35 & 100 \\ 8 & 0-20 & 83 \\ 3 & 1-10 & 100 \\ 2 & 0-3 & 83\end{array}$

Grasses

MARSh REed GRASS

(Calamagrostis canadensis) 5

\section{ENVIRONMENTAL VARIABLES}

\section{Moisture Regime:}

SUBHYGRIC

NUTRIENT REGIME:

$\mathrm{RICH}$

ELEVATION:

455-606 M

SOIL DRAINAGE:

MODERATELY WELL

Ecological Status Score: 18

\section{FORAGE PRODUCTION(KG/HA)}
Grass $\quad 130(0-260)$
FORBS 525(350-700)
SHRUBS $155(50-260)$
TREE 75(0-150)
TotAL 885(660-1110)

ECOLOGICALLY SUSTAINABLE STOCKING RATE

$2.7 \mathrm{ha} / \mathrm{AUM}(4.05-2.02)$

0.15 AUM/ac (0.1-0.2) 


\section{DMC9. Pb-Aw/Horsetail \\ (Populus balsamifera-Populus tremuloides/Equisetum arvense)}

$\mathbf{n = 5}$ This community occupies lowland sites adjacent to black spruce and willow lowlands. It is very moist and nutrient-rich. Horsetail types in the other subregions also tend to be moister and richer than the model Aw/Rose types. Past overgrazing pressure appears to have been heavy at one of the sites has resulted in an alteration of understory species composition and productivity. Overuse appears to lower species diversity and allows horsetail to increase in cover.

\section{Plant Composition Canopy Cover $(\%)$}

TREES

\section{ASPEN}

(Populus tremuloides)

BALSAM POPLAR

(Populus balsamifera)

25

$0-85$

60

$41 \quad 0-75$

80

\section{SHRUBS}

\section{PRICKLY Rose}

(Rosa acicularis)

HONEYSUCKLE

(Lonicera involcrata)

RED OSIER DOGWOOD

(Cornus stolonifera)

\section{FORBS}

\section{HORSETAIL}

(Equisetum arvense)

BUNCHBERRY

(Cornus canadensis)

TALL LUNGWORT

(Mertensia paniculata)

DEWBERRY

(Rubus pubescens)

VEINY MEADOW RUE

(Thalictrum venulosum)

BISHOP's CAP

(Mitella nuda)

STRAWBERRY

(Fragaria virginiana)

\section{Grasses}

MARSH REED GRASS

(Calamagrostis canadensis) 2

\section{ENVIRONMENTAL VARIABLES}

Moisture Regime:

HYGRIC

Nutrient REgIME:

RicH

Elevation:

590-667 M

SoIl DRAINAGE:

IMPERFECTLY

Ecological Status Score: 18

\section{FORAGE PRODUCTION(KG/HA)}

\author{
GRASS 188(104-272) \\ FORBS 544(450-638) \\ SHRUBS 302(0-604) \\ TotAL 1034(910-1158)
}

ECOLOGICALLY SUSTAINABLE STOCKING RATE $4.05 \mathrm{ha} / \mathrm{AUM}(4.05-2.02)$

$0.1 \mathrm{AUM} / \mathrm{ac}(0.1-0.2)$ 


\section{DMC10. Deciduous cutblocks and unseeded clearings \\ (Populus tremuloides)}

$\mathbf{n = 4}$ This community type represents deciduous cutblocks and clearings that have not been seeded to tame forage species. [Note: it is also the "best fit" for recently burnt areas that remain undescribed in the guide to date.] Marsh reed grass and strawberry initially dominated these areas. As succession occurs an understory of aspen and rose predominate. As the tree cover increases the understory species structure and diversity declines. Initially these clearings are very productive for domestic livestock until the trees grow back and limit accessiblity. Care should be taken when grazing these cutblocks that the trees are not damaged and there is sufficient regrowth to regenerate the cutblock.

\section{Plant Composition Canopy Cover(\%)}

MEAN RANGE CONST.

\section{UNDERSTORY TREES}

\section{BALSAM POPLAR}

\section{(Populus balsamifera)}

ASPEN

(Populus tremuloides)

$\mathrm{T}$

$0-1$

25

$19 \quad 11-28 \quad 100$

\section{SHRUBS}

PRICKLY ROSE

(Rosa acicularis)

$18 \quad 9-22 \quad 100$

LOW BUSH CRANBERRY

(Viburnum edule)

$2 \quad 0-4 \quad 75$

SNOWBERRY OR BUCKBRUSH

(Symphoricarpos

occidentalis)

$3 \quad 0-11 \quad 75$

WILD RED RASPBERRY

(Rubus idaeus)

5

$0-16$

50

\section{FORBS}

WILD STRAWBERRY

(Fragaria virginiana)

22

$8-38$

100

Palmate-leaved Coltsfoot

(Petasites palmatus) 2

DEWBERRY OR RUNNING RASPBERRY

(Rubus pubescens)

NORTHERN BEDSTRAW

(Galium boreale)

LINDLEY'S ASTER

(Aster ciliolatus)

$2-0-8$

$0-8$

4

$0-14$

Grasses

Marsh ReEd GRAss

(Calamagrostis canadensis)

\section{ENVIRONMENTAL VARIABLES}

Moisture Regime:

Mesic

NUTRIENT REgIME:

MESOTROPHIC

ELEVATION:

$$
\text { 455-727(636) M }
$$

Percent Slope Gradient:

LEVEL

SoIL DRAINAGE:

WELL

ECological Status Score: 18-0

\section{FORAGE PRODUCTION(KG/HA)}
GRASS 623
FORBS 580
SHRUBS 810
TOTAL 2013

ECOLOGICALLY SUSTAINABLE STOCKING RATE $2.02 \mathrm{ha} / \mathrm{AUM}(4.05-1.35)$

$0.2 \mathrm{AUM} / \mathrm{ac}(0.1-0.3)$ 


\section{DMC11. Pb/Honeysuckle \\ (Populus balsamifera/Lonicera involcrata)}

$\mathbf{n = 8}$ This community type occupies mid to lower slope positions which receive nutrient rich seepage from upslope. It has similar moisture and nutrient regimes to the red osier dogwood dominated sites, but it has a very low cover of red osier dogwood which distinguishes this community type from the red osier dogwood dominated communities. The lack of red osier dogwood cover may be indicative of increased grazing pressure or this community may represent the transition to the Lower Foothills subregion. Indeed Lane et al. (2000) described an Aw/Honeysuckle in the Lower Foothills subregion and red osier dogwood was not as common in this subregion. This community type has a very diverse shrub and forb layer, but the high cover of shrubs often restricts access to livestock, limiting forage availability.

\section{PLANT COMPOSITION CANOPY COVER(\%)}

MEAN RANGE CONST.

TreEs

BALSAM POPLAR

(Populus balsamifera) $\quad 53 \quad 20-70 \quad 100$

ASPEN

(Populus tremuloides)

$8 \quad 0-20$

\section{SHRUBS}

LOW BUSH CRANBERRY

(Viburnum edule)

PRICKLY Rose

(Rosa acicularis)

BRACTED HONEYSUCKLE

(Lonicera involucrata)

RASPBERRY

(Rubus idaeus)

$4 \quad 0-20$

63

$11 \quad 0-20 \quad 88$

$9 \quad 3-10$

100

$11 \quad 3-40$

100

\section{FORBS}

DEWBERRY OR RUNNING RASPBERRY

(Rubus pubescens)

$3 \quad 0-10$

BUNCHBERRY

(Cornus canadensis)

WILD STRAWBERRY

(Fragaria virginiana)

4

$0-20$

88

SHOWY ASTER

3

$0-10$

88

(Aster conspicuus)

3

$1-10$

100

TALL LUNGWORT

(Mertensia paniculata)

YELLOW PEAVINE

(Lathyrus ochroleucus)

\section{2}

$0-5$

88

Grasses

MARSh REED GRASS

(Calamagrostis canadensis) 2

1-3

\section{ENVIRONMENTAL VARIABLES}

\section{MOISTURE REGIME:}

SUBHYGRIC

NUTRIENT REGIME:

RICH

ELEVATION:

$$
\text { 590--648(630) M }
$$

Percent Slope Gradient:

$$
0
$$

Soll Drainage:

$$
\text { Moderately WELL }
$$

Ecological Status Score: 18

\section{FORAGE PRODUCTION(KG/HA)}
Grass 105
FORBS 450
SHRUBS 604
TOTAL 1191

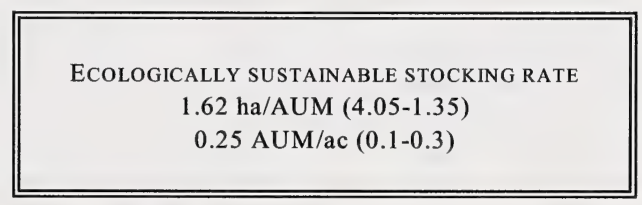




\section{DMC12. Pb/River alder (Populus balsamifera/Alnus tenuifolia)}

$\mathbf{n = 2}$ This community is found on lower slopes along natural drainages or areas with high water tables. River alder persists on moist sites and is replaced by green alder on drier upper slope positions. This community is similar to the $\mathrm{Pb}-\mathrm{Aw} /$ River alder community described by Beckingham and Archibald (1996) in the Boreal Mixedwood of Northern Alberta and is part of the dogwood ecosite. Production of this community type is very high because of the high moisture and nutrient conditions, however a large component of the total forage production is coming from alder which is generally unpalatable to livestock.

\section{Plant Composition Canopy Cover $(\%)$} MEAN RANGE CONST.

TREES

BALSAM POPLAR

$\begin{array}{llll}\text { (Populus balsamifera) } & 50 \quad 50-60 & 100\end{array}$

SHRUBS

PRICKLY Rose

(Rosa acicularis)

RIVER ALDER

(Alnus tenuifolia)

RED OSIER DOGWOOD

(Cornus stolonifera)

$12 \quad 3-20 \quad 100$

FORBS

HORSETAIL

(Equisetum arvense)

DANDELION

$\begin{array}{llll}\text { (Taraxacum officinale) } & 2 & 1-3 & 100\end{array}$

STAR FLOWERED SOLOMON SEAL

(Smilacina stellata)

Grasses

MARSh REED GRASS

(Calamagrostis canadensis) 1

HAIRY WILD RYE

(Elymus innovatus)
$1 \quad 1-2$

5

$55 \quad 50-60$

100

100

100

$-2 \quad 100$

$0-1 \quad 50$

$0-1 \quad 50$

\section{ENVIRONMENTAL VARIABLES}

\section{Moisture Regime:}

SUBHYGRIC

NUTRIENT REGIME: RICH

ELEVATION: 556-646(587) M

Percent SLOPE GRAdient: $1-5(3) \%$

SoIL DRAINAGE:

MODERATELY WELL

Ecological Status Score: 18

FORAGE PRODUCTION(KG/HA)

Total $1187 *$ Estimate

ECOLOGICALLY SUSTAINABLE STOCKING RATE 4.05 ha/AUM (4.05-2.02)

$0.1 \mathrm{AUM} / \mathrm{ac}(0.1-0.2)$ 


\section{DMC13. Pb-Aw/Silverberry \\ (Populus balsamifera-P. tremuloides/Elaeagnus commutata)}

$\mathbf{n = 3}$ This community is scattered throughout the Dry Mixedwood subregion. It appears to represent the invasion of aspen and balsam poplar onto silverberry shrublands. Silverberry thickets can occur on alluvial floodplain terraces, in V-shaped ravines and swale-like depressions where overland flows provide additional moisture (Thompson and Hansen 2002). The open nature and high productivity on these silverberry dominated communities make them attractive to livestock grazing. The understory of these communities are often dominated by Kentucky bluegrass, smooth brome and dandelion. Thompson and Hansen (2002) felt that silverberry dominated communities represented a grazing disclimax of red osier dogwood communities in Southern Alberta.

\section{Plant Composition Canopy Cover(\%)}

Trees

TREMBLING ASPEN

(Populus tremuloides)

BALSAM POPLAR

(Populus balsamifera)

\section{SHRUBS}

PrICKLY ROSE

(Rosa acicularis)

YELLOW WILLOW

(Salix lutea)

SiLVERBERRY

(Elaeagnus commutata)

\section{FORBS}

DANDELION

(Taraxacum officinale)

SHOWY ASTER

(Aster conspicuus)

HoRsETAIL

(Equisetum arvense)

STRAWBERRY

(Fragaria virginiana)

YELLOW PEAVINE

(Lathyrus ochroleucus)

Grasses

KENTUCKY BLUEGRASS

(Poa pratensis)

SMOOTH BROME

(Bromus inermis)

$\begin{array}{lll}17 & 0-50 & 33 \\ 31 & 3-50 & 100\end{array}$

\section{MEAN RANGE CONST.}

$\begin{array}{lll}11 & 3-20 & 100 \\ 4 & 1-10 & 100 \\ 23 & 20-30 & 100\end{array}$

100

66

66

100

\section{ENVIRONMENTAL VARIABLES}

\section{Moisture Regime:}

\section{SUBHYGRIC}

NUTRIENT REgIME:

RICH

ELEVATION:

$$
570-690(630) \mathrm{M}
$$

SoIL DrainAge:

Moderately WELL

ECOlOgical Status Score: 12

\section{FORAGE PRODUCTION(KG/HA)}

Total $1100 *$ Estimate

ECOLOGICALLY SUSTAINABLE STOCKING RATE

$2.02 \mathrm{ha} / \mathrm{AUM}(4.05-1.01)$

0.2 AUM/ac (0.1-0.4) 


\section{DMC14. Pb/Snowberry \\ (Populus balsamifera/Symphoricarpos occidentalis)}

$\mathbf{n = 3}$ This community type occupies small seepage areas on slopes above creeks and rivers in the Dry Mixedwood subregion. Snowberry prefers well drained habitats and has been found to quite common on forested slopes and river flood plains throughout the Boreal forest (Lane et al. 2000). The presence of balsam poplar indicates that the moisture content is sufficient to support its growth in this community. This community type is usually found in only small isolated spots.

\section{Plant Composition Canopy Cover(\%)}

\section{TREES}

MEAN RANGE CONST.

Trembling Aspen

(Populus tremuloides)

BALSAM POPLAR

(Populus balsamifera)

$36 \quad 3-80$

100

\section{SHRUBS}

PRICKLY ROSE

(Rosa acicularis)

SNOWBERRY

(Symphoricarpos

occidentalis)

RED OSIER DOGWOOD

(Cornus stolonifera)

$\begin{array}{lll}22 & 6-20 & 100 \\ 5 & 1-10 & 100\end{array}$

FORBS

BUNCHBERRY

(Cornus canadensis)

STRAWBERRY

(Fragaria virginiana)

NORTHERN BEDSTRAW

(Galium boreale) 1

$17-10-20$

100

DANDELION

(Taraxacum officinale)

YELLOW PEAVINE

(Lathyrus ochroleucus)

Grasses

MaRsh ReEd Grass

(Calamagrostis canadensis) $1 \quad 0-1 \quad 66$

KENTUCKY BLUEGRASS

(Poa pratensis)

3

$0-10$

\section{ENVIRONMENTAL VARIABLES}

Moisture Regime:

SUBHYGRIC

NUTRIENT REgIME:

RICH

ELEVATION:

556-709(624) M

SOIL DRAINAGE:

MOderately WELL

Ecological Status Score: 12

FORAGE PRODUCTION(KG/HA)

Total $1204 *$ Estimate

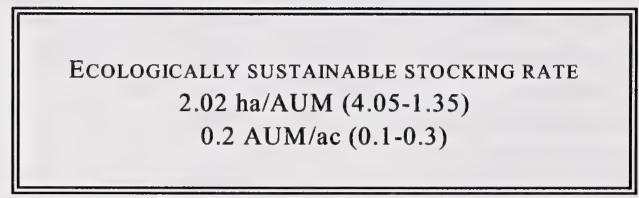




\section{DMC15. $\mathrm{Pb} /$ Reed grass \\ (Populus balsamifera/Calamagrostis stricta)}

$\mathbf{n = 2}$ This community type is not common in the Dry Mixedwood subregion. It appears to represent the invasion of balsam poplar onto reed grass and reed canary grass dominated meadows. As sloughs and small lakes dry up the edge communities become drier which favours the growth of trees and shrubs. If drying continues this community will likely succeed to $\mathrm{Pb} / \mathrm{Red}$ osier dogwood dominated community type. However, if flooding increases balsam poplar will likely decline. This community type is very productive for domestic livestock and the open nature of the understory also allows for good access.

\section{Plant Composition canopy Cover(\%)}

\section{Trees}

MEAN RANGE CONST.

BALSAM POPLAR

(Populus balsamifera)

$$
40
$$

$20-60$

100

\section{SHRUBS}

RED OSIER DOGWOOD

(Cornus stolonifera)

FORBS

THISTLE

(Cirsium arvense)

Horset AIL

(Equisetum arvense)

Sow THISTLE

(Sonchus arvensis)

DANDELION

(Taraxacum officinale)

\section{GraSSES}

NARROW REED GRASS

(Calamagrostis stricta)

REED CANARY GRASS

(Phalaris arundinacea)

WATER SEDGE

(Carex aquatilis)

\section{ENVIRONMENTAL VARIABLES}

Moisture Regime:

SUBHYGRIC TO SUBHYDRIC

Nutrient REgIME:

RICH

ELEVATION:

556-693(617) M

SoIL Drainage:

MODERATELY WELL TO IMPERFECTLY

Ecological Status Score: 12

\section{FORAGE PRODUCTION(KG/HA)}

Total $2150 *$ Estimate

ECOLOGICALLY SUSTAINABLE STOCKING RATE

$0.81 \mathrm{ha} / \mathrm{AUM}(0.81-0.4)$

0.5 AUM/ac (0.5-1.0) 


\section{DMC16. Bw/Labrador tea \\ (Betula papyrifera/Ledum groenlandicum)}

$\mathbf{n = 1}$ This community type represents a treed poor fen ecosite that was recently burned in Elk Island National Park. The poor fen ecosite is intermediate in nutrient regime between the bog and the rich fen ecosites (Beckingham and Archibald 1996). The presence of Labrador tea and short sedge is indicative of the acidic soil conditions. Treed poor fens are often dominated by black spruce in the Boreal Mixedwood (Beckingham and Archibald 1996), however the frequent fire regime in the park has burned the black spruce canopy and the site has become dominated by paper birch a early successional species in these boggy areas. These boggy community types are often too wet for domestic livestock and the species growing in them are often unpalatable.

\section{Plant Composition Canopy Cover(\%)} MEAN RANGE CONST.

TREES

PAPER BIRCH

(Betula papyrifera)

ASPEN

(Populus tremuloides)

$40-$

100

\section{ShrubS}

LABRADOR TEA

(Ledum groenlandicum)

CURRANT

(Ribes triste)

RASPBERRY

(Rubus idaeus)

BLUEBERRY

(Vaccinium myrtilloides)

\section{FORBS}

FIREWEED

(Epilobium angustifolium)

SKULl CAP

(Scutellaria galericulata)

100

\section{ENVIRONMENTAL VARIABLES}

Moisture Regime:

SUBHYDRIC

Nutrient REgIME:

POOR

ElEVATION:

$625 \mathrm{M}$

Soll Drainage:

POORLY

Ecological Status Score: 18

HEALTH FORM: RIPARIAN

FORAGE PRODUCTION(KG/HA)

Total $750 *$ Estimate

100

100
ECOLOGICALLY SUSTAINABLE STOCKING RATE

40.47 ha/AUM

$0.01 \mathrm{AUM} / \mathrm{ac}$ ) 


\section{DMC17. Bw/Raspberry \\ (Betula papyrifera/Rubus idaeus)}

$\mathbf{n}=\mathbf{2}$ This community type was described adjacent to old beaver dams. Cutting of the adjacent tree canopy and the increased moisture around the dam favours the growth of paper birch and raspberry. Both species are early successional and will rapidly dominate a site after disturbance. As the site drys and undergoes succession it will likely succeed to willow and eventually balsam poplar and white spruce. This community occupies small areas adjacent to the ponds and sloughs and is generally too wet for livestock.

\section{Plant Composition Canopy Cover(\%)}

MEAN RANGE CONST.

\section{TREES}

PAPER BIRCH

(Betula papyrifera)

ASPEN

$$
85 \quad 80-90
$$

100
(Populus tremuloides)

\section{SHRUBS}

\section{Rose}

(Rosa acicularis)

SCOULER's WILLOW

(Salix scouleriana)

RASPBERRY

(Rubus ideaus)

\section{ForbS}

FIREWEED

(Epilobium angustifolium)

BUNCHBERRY

(Cornus cornuta)

50

50

50

100

$10 \quad 10-11 \quad 100$

Grasses

MARSH REED GRASS

(Calamagrostis canadensis) 15
$1-30$
50

50

\section{ENVIRONMENTAL VARIABLES}

Moisture Regime:

SUBHYDRIC

NUTRIENT REGIME:

RICH

ELEVATION:

$625 \mathrm{M}$

SoIL DRAINAGE:

POORLY

ECOLOGICAL STATUS SCORE: 18

\section{FORAGE PRODUCTION(KG/HA)}

Total $1000 *$ ESTIMATE

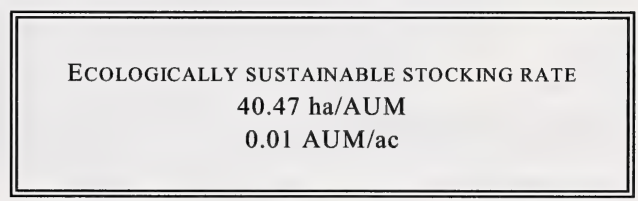




\section{DMC18. Pb-Bw/Kentucky bluegrass (Populus balsamifera-Betula papyrifera/Poa pratensis)}

$\mathbf{n}=\mathbf{5}$ This community represents a $\mathrm{Pb}$ or $\mathrm{Bw} /$ Red osier dogwood community that has recieved prolonged heavy grazing. This community type often occurs in relatively small isolated patches created by intensive grazing adjacent to water, salt or temporary holding areas. The species richness and diversity of native shrubs, forbs, and grass is reduced and replaced by grazing resistant species like clover, dandelion and Kentucky bluegrass.

\section{Plant Composition Canopy Cover(\%)}

MEAN RANGE CONST.

TREES

Trembling Aspen

(Populus tremuloides)

BALSAM POPLAR

(Populus balsamifera)

PAPER BIRCH

(Betula papyrifera)

$$
4
$$

$0-10$

80

$54 \quad 30-80$

100

SHRUBS

WILLOW SPP.

(Salix spp.)

WILD RED RASPBERRY

(Rubus idaeus)

SNOWBERRY

(Symphoricarpos

occidentalis)

PRICKLY ROSE

(Rosa acicularis)

$0-40$

60

\section{FORBS}

FIREWEED

(Epilobium angustifolium) $1 \quad 0-1$

DEWBERRY OR RUNNING RASPBERRY

$\begin{array}{lccc}\begin{array}{l}\text { (Rubus pubescens) } \\ \text { CLOVER } \\ \text { (Trifolium spp.) }\end{array} & 4 & 0-20 & 80 \\ \begin{array}{l}\text { WILD STRAWBER } \\ \text { (Fragaria virginiana) }\end{array} & 2 & 0-10 & 60 \\ \begin{array}{l}\text { SHOWY AsTER } \\ \text { (Aster conspicuus) }\end{array} & 2 & 1-3 & 100 \\ \begin{array}{l}\text { Horsetail } \\ \text { (Equisetum arvense) } \\ \begin{array}{l}\text { DANDELION } \\ \text { (Taraxacum officinale) }\end{array}\end{array} & 2 & 1-3 & 100 \\ \end{array}$

\section{Grasses}

MARSH REED GRASS

(Calamagrostis canadensis) $1 \quad 0-3 \quad 80$

KENTUCKY BLUEGRASS

$\begin{array}{llll}\text { (Poa pratensis) } & 9 & 1-20 & 100\end{array}$

QUACKGRASS

$\begin{array}{llll}\text { (Agropyron repens) } & 1 & 0-3 & 60\end{array}$

\section{ENVIRONMENTAL VARIABLES}

MoIsture Regime

SUBHYGRIC

NUTRIENT REGIME:

RICH

ELEVATION:

$$
\text { 455-697(524) M }
$$

Percent Slope Gradient:

$$
0-5
$$

SoIL DrainAGE:

MOderATELY WELL

Ecological Status Score: $6-0$

FORAGE PRODUCTION(KG/HA)

Total $1150 *$ Estimate

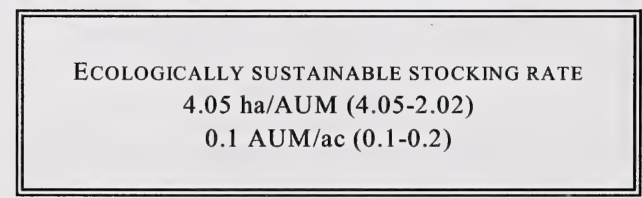




\section{DMC19. Pb/Smooth brome \\ (Populus balsamifera/Bromus inermis)}

$\mathbf{n = 2}$ This community type is similar to the previously described red osier dogwood and balsam poplar dominated community types, but has a high cover of smooth brome in the understory. Smooth brome is an introduced grass that can increase with increased grazing pressure, but invade into ungrazed areas. The invasion of non-native invaders onto the site makes this community moderately productive for domestic livestock.

\section{Plant Composition Canopy Cover(\%)}

\section{MEAN RANGE CONST.}

\section{TREES}

BALSAM POPLAR

$\begin{array}{llll}\text { (Populus balsamifera) } & 70 & 60-80 & 100\end{array}$

\section{SHRUBS}

WILLOW SPP.

(Salix spp.)

WILD RED RASPBERRY

(Rubus idaeus)

SNOWBERRY

(Symphoricarpos

occidentalis)

RED OSIER DOGWOOD

(Cornus stolonifera)

$\begin{array}{lll}67 & 3-10 & 100 \\ 10 & 0-20 & 50\end{array}$$$
3-10
$$$$
100
$$$$
10 \quad 1-20
$$

FORBS

\section{Clover}

(Trifolium spp.)

HORSETAIL

(Equisetum arvense)

DANDELION

(Taraxacum officinale) $2 \quad 1-3$

STAR FLOWERED SOLOMON SEAL

(Smilacina stellata)

7

SHOWY ASTER

(Aster conspicuus)

RICHARDSON GERANIUM

(Geranium richardsonii)

HEMP-NETTLE

(Galeopsis tetrahit)

$3-10$

$2 \quad 1-3 \quad 100$

$10 \quad 0-20$

50

$5 \quad 0-10 \quad 50$

Grasses

SMOOTH BROME

(Bromus inermis)

KENTUCKY BLUEGRASS

(Poa pratensis)

QUACKGRASS

(Agropyron repens)
$1-20$

100

$5 \quad 0-10$

50
ENVIRONMENTAL VARIABLES

MOISTURE REGIME:

SUBHYGRIC

NUTRIENT REGIME:

$$
\text { RICH }
$$

ELEVATION:

$$
\text { 455-697(524) M }
$$

Percent Slope Gradient:

$$
0-5
$$

SoIL DRAINAGE:

WELl TO MODERATELY WELL

Ecological Status Score: 6-0

\section{FORAGE PRODUCTION(KG/HA)}

Total $1250 *$ EstimATE

ECOLOGICALLY SUSTAINABLE STOCKING RATE $4.05 \mathrm{ha} / \mathrm{AUM}$ (4.05-2.02)

0.1 AUM/ac (0.1-0.2) 


\section{DRY MIXEDWOOD SUBREGION}

\section{CONIFEROUS AND MIXEDWOOD FOREST COMMUNITIES}

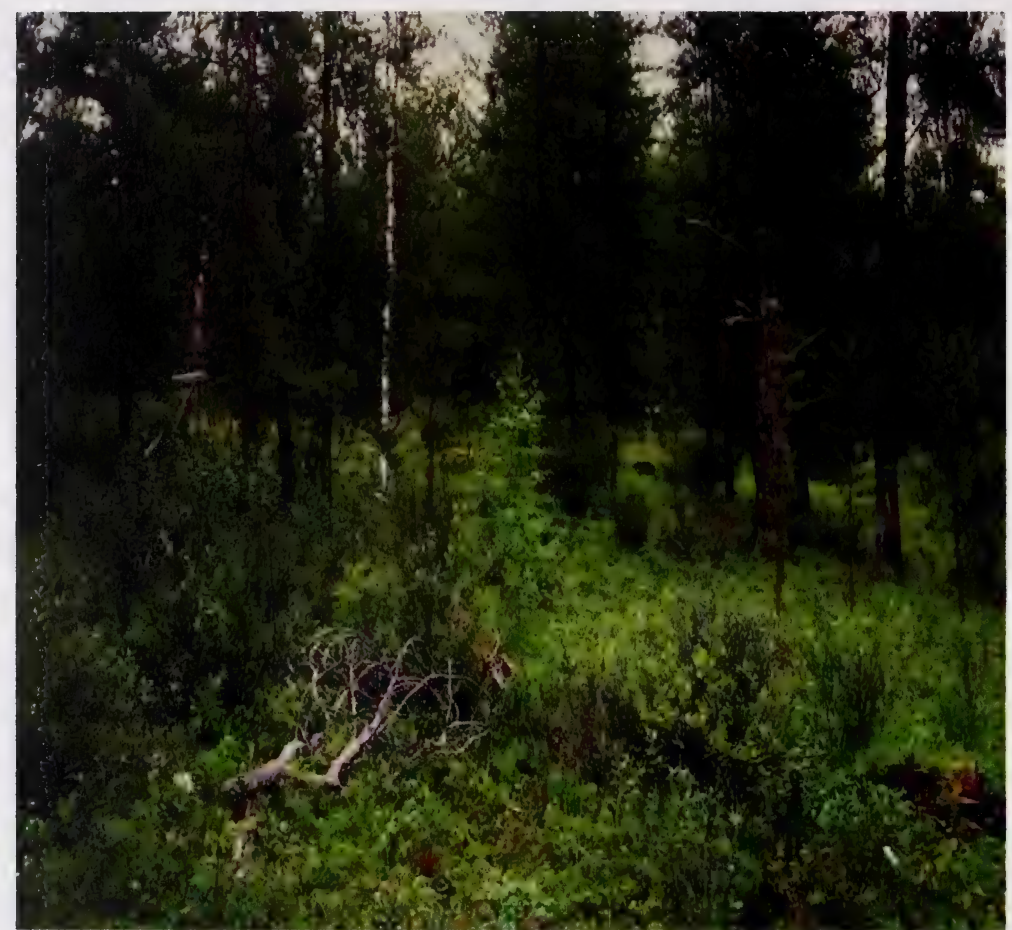

Photo 6. Pj/Bearberry community type in the Dry Mixedwood subregion 


\section{CONIFEROUS AND MIXEDWOOD FORESTS}

Communities which have begun to undergo succession from deciduous to conifer overstory may fall into the MIXEDWOOD category. The following is a general rule of thumb. The site is a mixedwood community if the conifer and the deciduous overstories each range between $30-70 \%$ of the total overstory cover. For example a deciduous cover of $40 \%$ and a conifer cover of $60 \%$ is a mixedwood community. If in doubt, determine if the understory is responding more to a deciduous or coniferous influence [e.g. loss of production due to conifer shading]. Communities dominated [i.e. $\geq 70 \%$ of the overstory] by a conifers are classified in the CONIFER category .

The mixedwood and coniferous community types described in this guide represent seven ecological sites (ecosites) as described by Beckingham and Archibald (1996). On sites with subxeric moisture and poor nutrient regimes, coarse textured, sandy soils open stands of jack pine generally dominate ( $\mathrm{Pj} / \mathrm{Alder}, \mathrm{Pj} /$ Bearberry). These community types commonly have a carpet of lichens covering the forest floor and a thin organic layer typically less than $5 \mathrm{~cm}$ thick (Beckingham and Archibald 1996).

On slightly moister sites with submesic moisture and medium nutrient regimes aspen grows in conjunction with jack pine to form the $\mathrm{Pj}-\mathrm{Aw} / \mathrm{Bearberry} \mathrm{community} \mathrm{type.} \mathrm{On} \mathrm{slightly} \mathrm{moister}$ sites Aw-Sw/Bearberry and Sw/Buffaloberry/Bearberry communities are found. The soils of these community types continue to be coarse-textured but the moisture and nutrient conditions are more favourable to the growth of aspen and spruce.

The mesic/medium sites are generally dominated by white spruce (Sw/Moss) and mixedwood communities of aspen and spruce (Aw-Sw/Rose/Marsh reed grass, Aw-Pb$\mathrm{Sw} / \mathrm{Willow} / \mathrm{Wild}$ sarsparilla, Sw-Pb-Aw/Rose/Twinflower, $\mathrm{Sw}-\mathrm{Aw} / \mathrm{Low}$ bush cranberry). These communities represent the reference ecological site for the Boreal Mixedwood subregion (Beckingham and Archibald 1996). Generally, these sites have moderately fine to fine-textured till or glaciolacustrine parent materials. Pioneer deciduous species (aspen, balsam poplar and birch) are replaced with white spruce and balsam fir as these sites develop successionally. With succession shade tolerant plants take over the herbaceous layer as conifers dominate the canopy. These shade tolerant species are unproductive and often unpalatable for domestic livestock. Forage productivity declines from $2.3 \mathrm{ha} / \mathrm{AUM}$ in a deciduous community to $2.3-8.6 \mathrm{ha} / \mathrm{AUM}$ in a mixedwood community to less than 10 ha/AUM in a conifer community.

Black spruce and larch communities generally dominate on wetter sites with subhygric to subhydric moisture regimes and poor to medium nutrient regimes to form the $\mathrm{Sb} / \mathrm{Willow} / \mathrm{Moss}$ and $\mathrm{Sb}-\mathrm{Lt} / \mathrm{Labrador}$ tea/Moss community types. Larch is more tolerant of excessive moisture and is indicative of an enriched nutrient status, while black spruce is typical in areas of stagnating ground water with poor nutrient status (Hay et al. 1985). Generally, these community types are considered non-use for domestic livestock. In contrast on the richer sites red osier dogwood and horsetail dominate the understory to form the $\mathrm{Sw} / \mathrm{Horsetail}$ and $\mathrm{Sw}-\mathrm{Pb} / \mathrm{Red}$ osier dogwood dominated communities.

Beckingham and Archibald (1996), provide a good description on how the conifer and mixedwood community types are arranged in the landscape. 


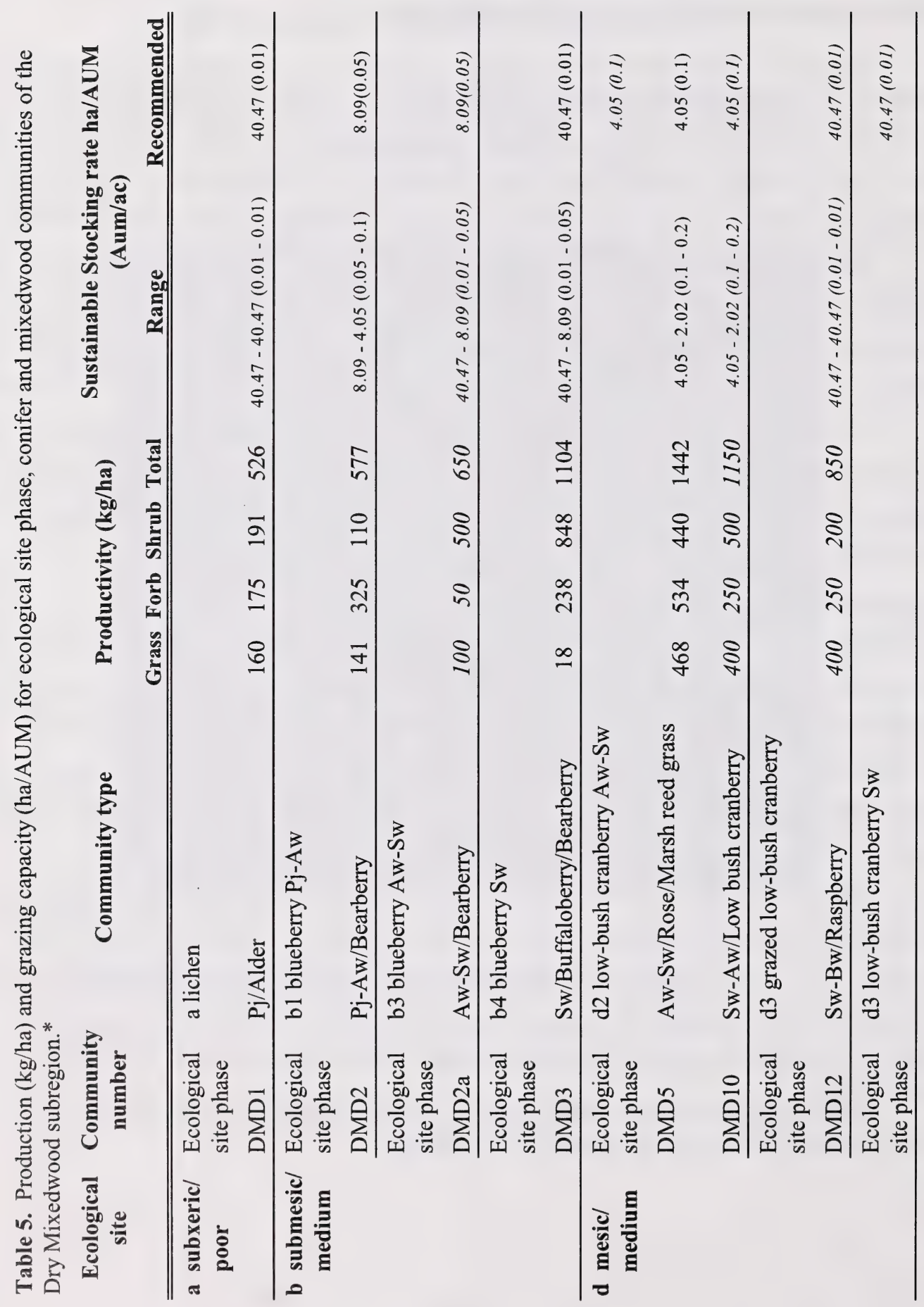

$\stackrel{\infty}{\Xi}$ 


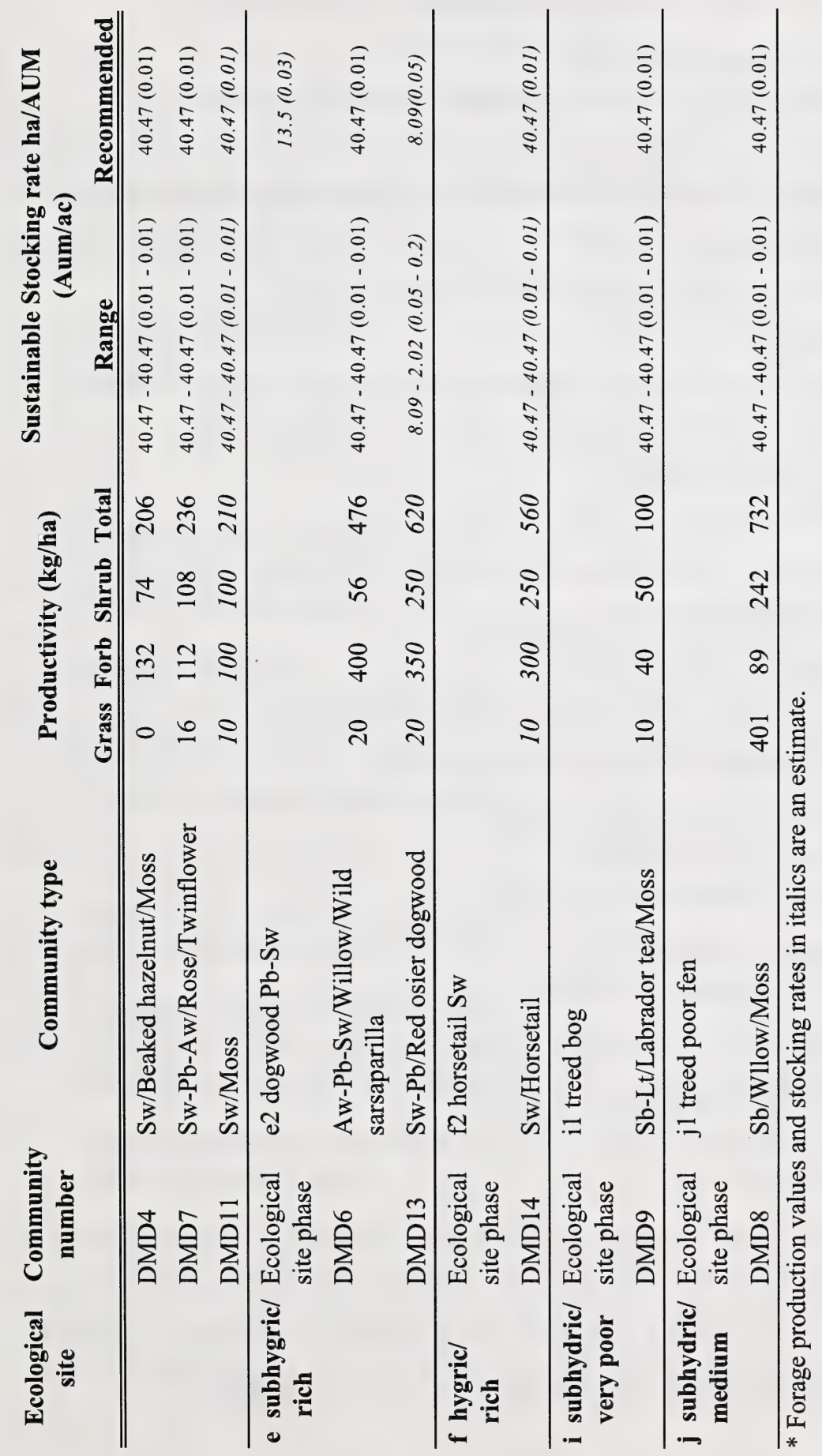




\section{Key to Conifer and Mixedwood* Types - Dry Mixedwood}

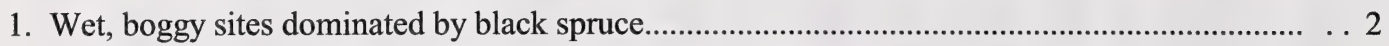

Moist, mesic or dry sandy sites dominated by white spruce, aspen, balsam poplar

or jack pine.

2. Richer nutrient sites with willow and sedge

dominating understory.

Sb/Willow/Moss (DMD8)

Poorer sites with Labrador tea and larch present.........Sb-Lt/Labrador Tea/Moss (DMD9)

3. Dry, sandy sites dominated by jack pine.

Mesic or subhygric sites dominated by spruce, aspen, balsam poplar.

4. Bearberry dominates, alder low in cover or absent

.Pj-Aw/Bearberry (DMD2)

Alder dominates understory

Pj/Alder (DMD1)

5. White spruce dominated (i.e. $\geq 70 \%$ spruce overstory cover, or deciduous species absent or their cover is $<30 \%$ ) or the understory is strongly influenced by conifer shading................. . . 6

Mixedwood types, dominated by a mixture of deciduous and conifer trees; and a structurally diverse understory present

6. Poorer nutrient sites, buffaloberry, bearberry dominate understory.

\section{.Sw/Buffaloberry/Bearberry (DMD3)}

Mesic sites; hazelnut, moss, low bush cranberry or raspberry predominant or present........... . . 7

7. Hazelnut dominates the understory.

.Sw/Hazelnut/Moss (DMD4)

Mesic sites with low bush cranberry, moss or raspberry.

8. Moss dominates understory, little shrub cover.

.Sw/Moss (DMD11)

Raspberry or low bush cranberry predominant or present in the understory...................... . 9

9. Raspberry dominates understory; recently disturbed sites......Sw-Bw/Raspberry (DMD12)

Low bush cranberry predominant or present in the understory.

..Sw-Aw/Low bush cranberry (DMD10)

10. Dry and mesic sites dominated by aspen and spruce .................................................. . 11

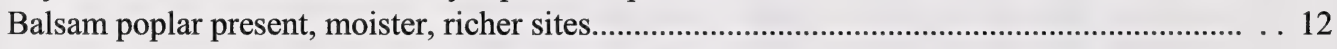

11. Typical mesic site, with rose and marsh reed grass.

Drier sites dominated by bearberry

Aw-Sw/Rose/Marsh Reed grass (DMD5)

Aw-Sw/Bearberry (DMD2a)

12. Twinflower dominates understory, poorer nutrient sites

Sw-Pb-Aw/Rose/Twinflower (DMD7)

Willow, wild sarsaparilla, red osier dogwood or horsetail dominate understory

13. Willow dominated understory.

Aw-Pb-Sw/Willow/Wild sarsaparilla(DMD6)

Red osier dogwood or horsetail dominates understory.

14. Red osier dogwood dominates understory.

Horsetail dominates understory.

$\mathrm{Sw}-\mathrm{Pb} / \mathrm{Red}$ osier dogwood (DMD13) Sw/Horsetail (DMD14)

*Communities which have begun to undergo succession from a deciduous to a conifer overstory may fall into the MIXEDWOOD category. The following is a general rule of thumb. The site is a mixedwood community if the conifer and the deciduous overstories each range between $30-70 \%$ of the total overstory cover. For example a deciduous cover of $40 \%$ and a conifer cover of $60 \%$ is a mixedwood community. If in doubt, try to determine if the understory is responding more to a deciduous or coniferous influence [e.g. loss of production due to conifer shading]. 


\section{DMD1. Pj/Alder \\ (Pinus banksiana/ Alnus crispa)}

$\mathbf{n = 2}$ This community type is found on dry, rapidly drained, sandy soils with a poor nutrient status. Consequently, production is quite low. Cattle will utilize these areas due to the easy access, however overutilization will quickly deplete the area of forage.

\section{Percent Composition Canopy Cover $(\%)$}

Trees

JACK PINE

(Pinus banksiana) $\quad 43 \quad 35-50 \quad 100$

\section{SHRUBS}

GREEN ALDER

(Alnus crispa)

PRICKLY ROSE

(Rosa acicularis)

SASKATOON

(Amelanchier alnifolia)

\section{FORBS}

TWIN-FLOWER

(Linnaea borealis)

BEARBERRY

(Arctostaphylos uva-ursi) 9

YELLOW PEAVINE

(Lathyrus ochroleucus)

STRAWBERRY

Fragaria virginiana)

Grasses

SEDGES

(Carex spp.)

HAIRY WILD RYE

(Elymus innovatus)

NORTHERN RICEGRASS

(Oryzopsis pungens)
MEAN RANGE CONST.

$33 \quad 30-35 \quad 100$

$9 \quad 7-10 \quad 100$

$5 \quad 1-8 \quad 100$

$6 \quad 0-12 \quad 50$

$0-18 \quad 50$

$0-8 \quad 50$

$1-2 \quad 100$

$6 \quad 1-11 \quad 100$

$3 \quad 1-4 \quad 100$

$6 \quad 1-10 \quad 100$

\section{ENVIRONMENTAL VARIABLES}

Moisture Regime: SUBXERIC

NUTRIENT REgIME

POOR

ELEVATION:

$606 \mathrm{M}$

SOIL DRAINAGE:

RAPIDLY

Percent Slope Gradient:

$$
2-8 \%
$$

ECOLOGICAL STATUS SCORE: 18

\section{FORAGE PRODUCTION(KG/HA)}

$\begin{array}{ll}\text { GRASS } & 160 \\ \text { FORBS } & 175 \\ \text { SHRUBS } & 191 \\ \text { TOTAL } & 526\end{array}$

ECOLOGICALLY SUSTAINABLE STOCKING RATE $40.47 \mathrm{ha} / \mathrm{AUM}$ (40.47-40.47)

$0.01 \mathrm{AUM} / \mathrm{ac}(0.01-0.01)$ 


\section{DMD2. Pj-Aw/Bearberry \\ (Pinus banksiana/Arctostaphylos uva-ursi)}

$\mathrm{n}=4$ This community represents a jack pine forest with a secondary canopy of aspen. It is very similar to the Pj/Alder community type, but it is found on slightly moister soils with better nutrient regimes. These conditions favour the growth of aspen. Like the previous community, cattle will utilize these areas due to the easy access, however overutilization will quickly deplete the forage supply.

\section{Plant Composition Canopy Cover(\%)}

\section{TREES}

MEAN RANGE CONST.

JACK PINE

(Pinus banksiana)

ASPEN

(Populus tremuloides)

45

$30-45$

100

$13 \quad 10-20 \quad 100$

\section{SHRUBS}

SASKATOON

(Amelanchier alnifolia)

PRICKLY ROSE

(Rosa acicularis)

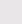

BLUEBERRY

(Vaccinium myrtilloides) 7

75

FORBS

BEARBERRY

(Arctostaphylos uva-ursi) 15

NORTHERN BEDSTRAW

(Galium boreale) 2

WILD LILY-OF-THE-VALLEY

(Maianthemum canadense)2

Cream-Coloured Vetchling

(Lathyrus ochroleucus) 7

.

Grasses

HAIRY WILD RYE

(Elymus innovatus)

10

2-16

100

Mosses

Moss SPP.

$0-7$

25

\section{ENVIRONMENTAL VARIABLES}

Moisture Regime:

SUBMESIC

Nutrient REgIME:

POOR

ELEVATION:

$606 \mathrm{M}$

Soll Drainage:

RAPIDLY

Percent Slope Gradient:

$$
0-5
$$

ECOLOGICAL STATUS SCORE: 18

\section{FORAGE PRODUCTION(KG/HA)}

$\begin{array}{ll}\text { GRASS } & 141 \\ \text { FORBS } & 325 \\ \text { SHRUBS } & 110 \\ \text { TOTAL } & 577\end{array}$

ECOLOGICALLY SUSTAINABLE STOCKING RATE 8.09 ha/AUM (8.09-4.05) 0.05 AUM/ac (0.05-0.1) 


\section{DMD2a. Aw-Sw/Bearberry \\ (Populus tremuloides-Picea glauca/Arctostaphylos uva-ursi)}

$\mathbf{n = 1}$ This community type was found on a small, sandy hillcrest with a high water table. It is similar to the Sw/Buffaloberry/Bearberry (DMD3) community type, but this community is successionally younger. The majority of productivity is from bearberry which is unpalatable to livestock.

\section{Plant COMPOSITION Canopy Cover(\%)}

Trees

MEAN RANGE CONST.

WHITE SPRUCE

(Picea glauca)

ASPEN

(Populus tremuloides)

$\begin{array}{lll}15 & - & 100 \\ 15 & - & 100\end{array}$

\section{SHRUBS}

SASKATOON

(Amelanchier alnifolia)

PRICKLY ROSE

(Rosa acicularis)

BLUEBERRY

(Vaccinium myrtilloides)

\section{FORBS}

BEARBERRY

(Arctostaphylos uva-ursi)

STRAWBERRY

(Fragaria virginiana)

YELLOW PEAVINE

(Lathyrus ochroleucus)

WILD-LILY-OF-THE VALLEY

(Maianthemum canadense)

37

100

100

$4 \quad-\quad 100$

$3 \quad 100$

\section{Grasses}

HAIRY WILD RYE

(Elymus innovatus)

NORTHERN RICEGRASS

(Oryzopsis pungens)
100

100

\section{ENVIRONMENTAL VARIABLES}

Moisture Regime:

SUBMESIC

NUTRIENT REGIME:

POOR

ELEVATION:

$606 \mathrm{M}$

SoIl DRAINAGE:

WELL

Percent Slope Gradient:

$$
0-4
$$

ECOLOGICAL STATUS SCORE: 18

\section{FORAGE PRODUCTION(KG/HA)}

Total $650 *$ ESTIMATE

ECOLOGICALLY SUSTAINABLE STOCKING RATE

8.09 ha/AUM (40.47-8.09)

$0.05 \mathrm{AUM} / \mathrm{ac}$ (0.01-0.05) 


\section{DMD3. Sw/Buffaloberry/Bearberry \\ (Picea glauca/Shepherdia canadensis/Arctostaphylos uva-ursi)}

$\mathbf{n = 1}$ This community type represents a very open spruce forest. It was found on a small, sandy hillcrest with a high water table. The site may have a high $\mathrm{pH}$ and be somewhat nutrient poor as indicated by the abundance of buffaloberry (Beckingham 1993). The majority of productivity is from buffaloberry which is unpalatable to livestock.

\section{Plant Composition CANopy Cover(\%)}

TREES

WHITE SPRUCE

(Picea glauca)

SHRUBS

BUFFALOBERRY

(Shepherdia canadensis)

PRICKLY ROSE

(Rosa acicularis)

BLUEBERRY

(Vaccinium myrtilloides)

MEAN RANGE CONST.

SNOWBERRY

(Symphoricarpos

occidentalis)

\section{FORBS}

BEARBERRY

(Arctostaphylos uva-ursi)

TWINFLOWER

(Linnaea borealis)

YELLOW PEAVINE

(Lathyrus ochroleucus)

TOADFLAX

(Comandra umbellata)

\section{GraSSES}

MOUNTAIN RICEGRASS

(Oryzopsis asperifolia)

NORTHERN RICEGRASS

(Oryzopsis pungens)

SEDGE

(Carex spp.)
$10 \quad-\quad 100$

$48 \quad-\quad 100$

$12 \quad 100$

\begin{tabular}{l}
$7 \quad 100$ \\
\hline
\end{tabular}

5

100

$19 \quad-\quad 100$

$12 \quad-\quad 100$

$8 \quad-\quad 100$

$2 \quad-\quad 100$

$8 \quad-\quad 100$

$6 \quad-\quad 100$

$5 \quad-\quad 100$

\section{ENVIRONMENTAL VARIABLES}

Moisture Regime:

\section{SUBMESIC}

NUTRIENT REgIME: POOR

ELEVATION: $606 \mathrm{M}$

Soll Drainage:

WELL

Percent Slope Gradient:

$$
0-4
$$

ECOLOGICAL STATUS SCORE: 18

FORAGE PRODUCTION(KG/HA)

$\begin{array}{lc}\text { GRASS } & 18 \\ \text { FORBS } & 238 \\ \text { SHRUBS } & 848 \\ \text { TOTAL } & 1104\end{array}$

ECOLOGICALLY SUSTAINABLE STOCKING RATE 40.47 ha/AUM (40.47-8.09)

$0.01 \mathrm{AUM} / \mathrm{ac}$ (0.01-0.05) 


\section{DMD4. Sw/Beaked hazelnut/Moss (Picea glauca/Corylus cornuta/Moss)}

$\mathbf{n = 1} \quad$ This is a mature white spruce forest which represents the climax or near climax vegetation for the area. The northerly aspect of this community type has probably protected the site from past disturbance by fires and allowed the community to undergo succession. The high canopy of spruce limits the light reaching the forest floor, limiting the growth of grasses and forbs. As a result, the forage productivity of this community type is very low.

\section{Plant Composition Canopy Cover(\%)}

\section{TREES}

White SPRuce

(Picea glauca)

PAPER BIRCH

(Betula papyrifera)

SHRUBS

HAZELNUT

(Corylus cornuta)

BOG CRANBERRY

(Vaccinium vitis-idaea)

PRICKLY ROSE

(Rosa acicularis)

\section{FORBS}

BEARBERRY

(Arctostapylos uva-ursi)

MEAN RANGE CONST.

TWINFLOWER

(Linnaea borealis)

BASTARD TOADFLAX

(Geocaulon lividum)

STRAWBERRY

(Fragaria virginiana)

\section{Mosses}

Moss SPP.

\section{ENVIRONMENTAL VARIABLES}

Moisture Regime: MESIC

NUTRIENT REGIME: MEDIUM

Elevation: $606 \mathrm{M}$

SoIL DRAINAGE: WELL

Percent Slope Gradient: $5 \%$

ASPECT:

NORTHERLY

ECOLOGICAL STATUS SCORE: 18

FORAGE PRODUCTION(KG/HA)

$\begin{array}{ll}\text { GRASS } & 0 \\ \text { FORBS } & 132 \\ \text { SHRUBS } & 74 \\ \text { TOTAL } & 206\end{array}$

ECOLOGICALLY SUSTAINABLE STOCKING RATE $40.47 \mathrm{ha} / \mathrm{AUM}(40.47-40.47)$

$0.01 \mathrm{AUM} / \mathrm{ac}$ (0.01-0.01) 


\section{DMD5. Aw-Sw/Rose/Marsh reed grass \\ (Populus tremuloides-Picea glauca/Rosa acicularis/Calamagrostis canadensis)}

$\mathbf{n}=\mathbf{2}$ This community represents a highly productive aspen community that is succeeding to white spruce. The presence of tall forbs wild sarsaparilla and fireweed indicate a high nutrient regime and a light grazing regime. At present this community type has a good level of forage for domestic livestock.

\section{Plant Composition Canopy Cover(\%)}

$$
\text { MEAN RANGE CONST. }
$$

Trees

WhITE SPRUCE

(Picea glauca)

Populus TREMUloIdes

(Populus tremuloides)

$\begin{array}{lrr}55 & 50-60 & 100 \\ 53 & 35-70 & 100\end{array}$

SHRUBS

PRICKLY ROSE
(Rosa acicularis)

WILD RED RASPBERRY

(Rubus idaeus)

BRISTLY BLACK CURRANT

(Ribes lacustre)

LOW BUSH CRANBERRY

(Viburnum edule)

\section{FORBS}

BUNCHBERRY

(Cornus canadensis)

FIELD HoRseTAIL

(Equisetum arvense)

TALL LUNGWORT

(Mertensia paniculata)

WILD SARSAPARILLA

(Aralia nudicaulis)

DEWBERRY

(Rubus pubscens)

FIREWEED

(Epilobium angustifolium)

$\begin{array}{lll}13 & 3-23 & 100 \\ 8 & 0-15 & 50 \\ 5 & 0-10 & 50 \\ 8 & 6-10 & 100\end{array}$

Grasses

MARSH REED GRASS

(Calamagrostis canadensis)

\section{ENVIRONMENTAL VARIABLES}

Moisture Regime: MESIC-SUBHYGRIC

NutRient REgIME: MEDIUM TO RICH

Elevation:

455-600(527) M

SoIL DRAINAGE:

WELl TO MODERATELY WELL

ECOLOGICAL STATUS SCORE: 18

FORAGE PRODUCTION(KG/HA)

$\begin{array}{ll}\text { GRASS } & 468 \\ \text { FORBS } & 534 \\ \text { SHRUBS } & 440 \\ \text { TOTAL } & 1442\end{array}$

ECOLOGICALLY SUSTAINABLE STOCKING RATE $4.05 \mathrm{ha} / \mathrm{AUM}(4.05-2.02)$

$0.1 \mathrm{AUM} / \mathrm{ac}(0.1-0.2)$ 


\section{DMD6. Aw-Pb-Sw/Willow/Wild sarsaparilla \\ (Populus tremuloides-Populus balsamifera-Picea glauca/Salix spp./Aralia nudicaulis)}

$\mathbf{n}=\mathbf{1}$ This community type has similar moisture and nutrient conditions to the $\mathrm{Aw}-\mathrm{Pb}$ and $\mathrm{Pb} / \mathrm{Red}$ osier dogwoodRose community types, but this community is successionally more advanced. The abundance of tall shrubs limits the amount of light reaching the forest floor, which limits forage production.

\section{Plant CoMposition Canopy Cover(\%)}

\section{TREES}

ASPEN

(Populus tremuloides)

White SPRUCE

(Picea glauca)

PAPER BIRCH

(Betula papyrifera)

BALSAM POPLAR

(Populus balsamifera)

\section{SHRUBS}

GREEN ALDER

(Alnus crispa)

WILLOW

(Salix spp.)

LOW BUSH CRANBERRY

(Viburnum edule)

PRICKLY Rose

(Rosa acicularis)

FORBS

WILD SARSAPARILLA

(Aralia nudicaulis)

BISHOP's CAP

(Mitella nuda)

CANADA VIOLET

(Viola canadensis)

LADY FERN

(Athyrium filix-femina)

DEWBERRY

(Rubus pubescens)
MEAN RANGE CONST.

\section{ENVIRONMENTAL VARIABLES}

MOISTURE REgIME: SUBHYGRIC

NUTRIENT REgIME:

RICH

Elevation:

$606 \mathrm{M}$

Soll DRAINAGE:

MODERATELY WELL

Percent Slope Gradient: $20 \%$

\section{ASPECT:}

EAST

ECOLOGICAL STATUS SCORE: 18

\section{FORAGE PRODUCTION(KG/HA)}

$\begin{array}{ll}\text { GRASS } & 20 \\ \text { FORBS } & 400 \\ \text { SHRUBS } & 56 \\ \text { TOTAL } & 476\end{array}$

ECOLOGICALLY SUSTAINABLE STOCKING RATE $40.47 \mathrm{ha} / \mathrm{AUM}(40.47-40.47)$ $0.01 \mathrm{AUM} / \mathrm{ac}(0.01-0.01)$ 


\section{DMD7. Sw-Pb-Aw/Rose/Twinflower}

\section{(Picea glauca-Populus balsamifera-Populus tremuloides/Rosa acicularis/Linnaea borealis)}

$\mathbf{n = 1}$ This community is similar to the previous described Aw-Pb-Sw/Willow/Wild sarsaparilla community type but is found on slightly drier sites with a poorer nutrient regime. Succession of this community type will likely be to a White spruce /Moss dominated community type. The thick overstory limits the growth of shrubs, forbs and grass.

Consequently, there is little forage for domestic livestock.

\section{Plant Composition Canopy Cover $(\%)$}

TREES

MEAN RANGE CONST.

White SPRUCE

(Picea glauca)

TREMBLING ASPEN

(Populus tremuloides)

BALSAM POPLAR

(Populus balsamifera)

\section{SHRUBS}

SNOWBERRY

(Symphoricarpos

occidentalis)

PRICKLY Rose

(Rosa acicularis)

BRACTED HONEYSUCKLE

(Lonicera involcrata)

BUFFALO-BERRY

(Shepherdia canadensis)

\section{FORBS}

TWIN-FLOWER

(Linnaea borealis)

BUNCHBERRY

(Cornus canadensis)

WINTERGREEN

(Pyrola asarifolia)

DEWBERRY

(Rubus pubscens)

BISHOP'S CAP

(Mitella nuda)

Mosses

Moss SPP.

$\begin{array}{lll}35 & - & 100 \\ 20 & - & 100 \\ 30 & - & 100\end{array}$

00

\section{ENVIRONMENTAL VARIABLES}

Moisture Regime:

MESIC TO SUbHYGRIC

Nutrient REgIME:

MEDIUM

ELEVATION:

$606 \mathrm{M}$

SoIL DRAINAGE:

Well to Moderately WELL

ECOLOGICAL STATUS SCORE: 18

\section{FORAGE PRODUCTION(KG/HA)}

$\begin{array}{lc}\text { GRASS } & 16 \\ \text { FORBS } & 112 \\ \text { SHRUBS } & 108 \\ \text { TOTAL } & 236\end{array}$

ECOLOGICALLY SUSTAINABLE STOCKING RATE $40.47 \mathrm{ha} / \mathrm{AUM}(40.47-40.47)$

$0.01 \mathrm{AUM} / \mathrm{ac}$ (0.01-0.01) 


\section{DMD8. Sb/Willow/Moss \\ (Picea mariana/Salix spp./Moss)}

$\mathbf{n}=\mathbf{2}$ This community type is part of the poor fen ecosite (Beckingham and Archibald 1996) because it has an intermediate nutrient regime between the bog and rich fen ecosites. Drainage on this community type is poor to very poor, but has some movement of water through the site. This community type has a well developed shrub layer and the grass layer consists mainly of marsh reed grass and sedge species. The productivity of this type is moderate, but the high water table limits access to domestic livestock.

\section{Plant Composition Canopy Cover(\%)}

TREES

BLACK SPRUCE

(Picea mariana)

\section{SHRUBS}

WILLOW SPP.

(Salix spp.)

BOG BIRCH

(Betula glandulosa)

MEAN

RANGE CONST.

FORBS

STEMLESS RASPBERRY

(Rubus arctica)

HorSETAIL

(Equisetum arvense)

BISHOP's CAP

(Mitella nuda)

\section{Grasses}

MARSH REED GRASS

(Calamagrostis canadensis)

HAIR-LIKE SEDGE

(Carex capillaris)

9-11

100

$5-10$

100

\section{Mosses}

Moss SPP.

99

\section{ENVIRONMENTAL VARIABLES}

Moisture Regime:

SUBHYDRIC

NUTRIENT REGIME: MEDIUM

ELEVATION:

$$
\text { 606-697(657) M }
$$

Soll Drainage:

POORLY

ECOLOGICAL STATUS SCORE: 18

HEALTH FORM: RIPARIAN

\section{FORAGE PRODUCTION(KG/HA)}

$\begin{array}{ll}\text { GRASS } & 401 \\ \text { FORBS } & 89 \\ \text { SHRUBS } & 242 \\ \text { TOTAL } & 732\end{array}$

ECOLOGICALLY SUSTAINABLE STOCKING RATE 40.47 ha/AUM (40.47-40.47)

$0.01 \mathrm{AUM} / \mathrm{ac}(0.01-0.01)$ 


\section{DMD9. Sb-Lt/Labrador tea/Moss (Picea mariana-Larix laricina/Ledum groenlandicum/Moss)}

$\mathbf{n}=\mathbf{3}$ This community type is very similar to the previously described community type, but the nutrient status is poorer. This community type appears to be related to the bog ecosite described by Beckingham and Archibald (1996). The bog ecosite commonly has organic soils consisting of slowly decomposing peat moss. This community type is has poor productivity and accessibility.

\section{Plant Composition Canopy Cover(\%)}

Trees

$$
\text { MEAN RANGE CONST. }
$$

LARCH

(Larix laricina)

BLACK SPRUCE

(Picea mariana)

10

$1-15 \quad 100$

$30 \quad 10-60 \quad 100$

\section{SHRUBS}

WILLOW SPP.

(Salix spp.)

LABRADOR TEA

(Ledum groenlandicum)

BOG BIRCH

(Betula glandulosa)

\section{FORBS}

DWARF BRAMBLE

(Rubus pedatus)

HoRSETAIL

(Equisetum arvense)

DWARF SCOURING RUSH

(Equisetum scirpoides)

21

$8-35$

100

23

$10-35 \quad 100$

0-39

100

\section{Grasses}

MARSH REED GRASS

(Calamagrostis canadensis)

GoLDEN SEDGE

(Carex aurea)

BEAKED SEDGE

(Carex rostrata)

Fowl BLUEGRASS

(Poa palustris)

$\begin{array}{lll}8 & 0-25 & 66 \\ 21 & 0-45 & 66 \\ 8 & 0-25 & 33\end{array}$

Mosses

Moss SPP.

\section{ENVIRONMENTAL VARIABLES}

Moisture Regime:

SUBHYDRIC

NUTRIENT REGIME:

VERY POOR

ElEVATION:

576-606 M

SoIl Drainage:

POOR

ECOLOGICAL STATUS SCORE: 18

HEALTH FORM: RIPARIAN

\section{FORAGE PRODUCTION(KG/HA)}

$\begin{array}{ll}\text { GRASS } & 10 \\ \text { FORBS } & 40 \\ \text { SHRUBS } & 50 \\ \text { TOTAL } & 100\end{array}$

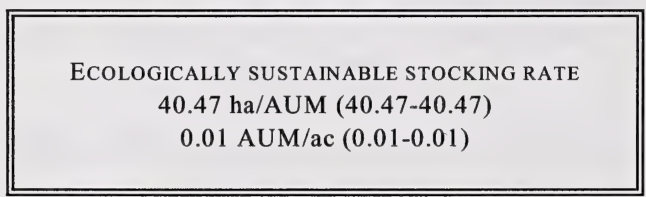




\section{DMD10. Sw-Aw/Low bush Cranberry (Picea glauca-Populus tremuloides/Viburnum edule)}

$\mathbf{n = 5}$ This community is similar to community DMD5 Aw-Sw, but is successional more advanced. As succession continues in the absence of disturbance on these sites there will be a corresponding drop in forage production. A spruce dominated forest generally produces about $1 / 3$ of an undisturbed deciduous dominated community type.

\section{Plant Composition Canopy Cover(\%)}

TreES

White SPRuce

(Picea glauca)

Populus TREMUloides

(Populus tremuloides)

SHRUBS

PRICKLY ROSE

(Rosa acicularis)

WILD RED RASPBERRY

(Rubus idaeus)

RED OSIER DOGWOOD

(Cornus stolonifera)

LOW BUSH CRANBERRY

(Viburnum edule)

FORBS

BUNCHBERRY

(Cornus canadensis)

FIELD HORSETAIL

(Equisetum arvense)

TALL LUNGWORT

(Mertensia paniculata)

WILD SARSAPARILLA

(Aralia nudicaulis)

DEWBERRY

(Rubus pubscens)

FIREWEED

(Epilobium angustifolium)

MEAN RANGE CONST.

$28 \quad 20-40 \quad 100$

$14 \quad 1-30 \quad 100$

Grasses

MARSH REED GRASS

(Calamagrostis canadensis) 3

$1 \quad 1-3 \quad 100$

$11 \quad 0-30 \quad 80$

$2 \quad 1-3 \quad 100$

$2 \quad 0-3 \quad 80$

$0-10 \quad 80$

\section{ENVIRONMENTAL VARIABLES}

Moisture Regime:

MESIC-SUBHYGRIC

Nutrient REgime:

MEDIUM TO RICH

ELEVATION:

455-600(527) M

SoIL DRAINAGE:

WELL TO MODERATELY WELL

ECOLOGICAL STATUS SCORE: 18

FORAGE PRODUCTION(KG/HA)

Total $1150 *$ Estimate

ECOLOGICALLY SUSTAINABLE STOCKING RATE

4.05 ha/AUM (4.05-2.02)

$0.1 \mathrm{AUM} / \mathrm{ac}(0.1-0.2)$ 


\section{DMD11. Sw/Moss \\ (Picea glauca/Moss spp.)}

$\mathbf{n = 1}$ This community is similar to community DMD10 Sw-Aw, but is successional more advanced. As succession continues in the absence of disturbance on these sites there will be a corresponding drop in forage production. A spruce dominated forest generally produces about $1 / 3$ of an undisturbed deciduous and mixed wood dominated community types.

\section{Plant Composition Canopy Cover(\%)}

\section{TREES}

White SPruce

(Picea glauca)

$$
\text { MEAN RANGE CONST. }
$$

\section{SHRUBS}

PRICKLY ROSE

(Rosa acicularis)

BRACTED HONEYSUCKLE

(Lonicera involcrata)

RED OSIER DOGWOOD

(Cornus stolonifera)

LOW BUSH CRANBERRY

(Viburnum edule)

$$
60
$$

100

\section{Forbs}

BUNCHBERRY

(Cornus canadensis)

FIELD HoRsETAIL

(Equisetum arvense)

TWINFLOWER

(Linnaea borealis)

DEWBERRY

(Rubus pubscens)

Grasses

PURPLE OAT GRASS

(Schizachne purpurascens)

100

100

100

\section{ENVIRONMENTAL VARIABLES}

Moisture Regime:

MESIC-SUBHYGRIC

NUTRIENT REgIME:

MEDIUM TO RICH

ELEVATION:

$600 \mathrm{M}$

Soll Drainage:

Well to Moderately Well

ECOLOGICAL STATUS SCORE: 18

\section{FORAGE PRODUCTION(KG/HA)}

TOTAL

$210 *$ EsTIMATE

ECOLOGICALLY SUSTAINABLE STOCKING RATE $40.47 \mathrm{ha} / \mathrm{AUM}(40.47-40.47)$

$0.01 \mathrm{AUM} / \mathrm{ac}$ (0.01-0.01) 


\section{DMD12. Sw-Bw/Raspberry \\ (Picea glauca-Betula papyrifera/Rubus ideaus)}

$\mathbf{n = 1}$ This community type was described near Astotin Lake in Elk Island National Park. It represents a site that has had historic beaver activity and since has undergone succession to a spruce dominated community. Cutting of the adjacent tree canopy and the increased moisture around the dam favours the growth of paper birch and raspberry. Both species are early successional and will rapidly dominate a site after disturbance. This community occupies small areas adjacent to the ponds and sloughs and therefore will contribute little to the overall carrying capacity of a lease.

\section{Plant COMPOSITION CANOPY COVER(\%)}

\section{TREES}

White SPRuce

(Picea glauca)

PAPER BIRCH

(Betula papyrifera)

SHRUBS

PRICKLY ROSE

(Rosa acicularis)

BRACTED HONEYSUCKLE

(Lonicera involucrata)

RASPBERRY

(Rubus idaeus)

LOW BUSH CRANBERRY

(Viburnum edule)

\section{FORBS}

WILD SARSAPARILLA

(Aralia nudicaulis)

HEMP NETTLE

(Galeopsis tetrahit)

FIREWEED

(Epilobium angustifolium)

SHOWY ASTER

(Aster conspicuus)

\section{Grasses}

QUACKGRASS

(Agropyron repens)

SMOOTH BROME

(Bromus inermis)

MEAN RANGE CONST.
50

100

20

100

100

100

100

40

100

100

10

10

100

100

100

\section{ENVIRONMENTAL VARIABLES}

MoistuRe Regime:

MESIC-SUBHYGRIC

NUTRIENT REGIME: MEDIUM

ELEVATION:

$600 \mathrm{M}$

SoIL Drainage:

Well to Moderately Well

ECOLOGICAL STATUS SCORE: 18

FORAGE PRODUCTION(KG/HA)

Total $850 *$ Estimate

ECOLOGICALLY SUSTAINABLE STOCKING RATE

$40.47 \mathrm{ha} / \mathrm{AUM}(40.47-40.47)$

$0.01 \mathrm{AUM} / \mathrm{ac}$ (0.01-0.01) 


\section{DMD13. Sw-Pb/Red osier dogwood (Picea glauca-Populus balsamifera/Cornus stolonifera)}

$\mathbf{n}=6$ This community is similar to community DMC8 Pb-Aw/Red osier dogwood, but is successional more advanced. As succession continues in the absence of disturbance on these sites there will be a corresponding drop in forage production. A spruce dominated forest generally produces about $1 / 3$ of an undisturbed deciduous dominated community type.

\section{Plant Composition Canopy Cover(\%)}

TREES

White SPRuce

(Picea glauca)

BALSAM POPLAR

(Populus balsamifera)

$$
\text { MEAN RANGE CONST. }
$$

SHRUBS

PRICKLY ROSE

(Rosa acicularis)

RED OSIER DOGWOOD

(Cornus stolonifera)

RIVER ALDER

(Alnus tenuifolia)

LOW BUSH CRANBERRY

(Viburnum edule)

$\begin{array}{lll}23 & 1-40 & 100 \\ 30 & 20-60 & 100\end{array}$

\section{FORBS}

WILD SARSAPARILLA

(Aralia nudicaulis)

HoRSETAIL

(Equisetum arvense)

STAR FLOWERED SOLOMON SEAL

(Smilacina stellata)

BUNCHBERRY

(Cornus canadensis)

\section{GRASSES}

MARSH REED GRASS

(Calamagrostis canadensis)

KENTUCKY BLUEGRASS

(Poa pratensis)

$7 \quad 3-20$

100

$14 \quad 3-20 \quad 100$

$11 \quad 3-30 \quad 100$

$2 \quad 0-10 \quad 67$

REDTOP

(Agrostis stolonifera)

\section{ENVIRONMENTAL VARIABLES}

MoISTURE REgIME:

SUBHYGRIC

NUTRIENT REgIME:

RICH

Elevation:

$600 \mathrm{M}$

SoIL Drainage:

Well to Moderately WELL

ECOLOGICAL STATUS SCORE: 18-12

FORAGE PRODUCTION(KG/HA)

Total $620 *$ Estimate

ECOLOGICALLY SUSTAINABLE STOCKING RATE 8.09 ha/AUM (8.09-2.02) $0.05 \mathrm{AUM} / \mathrm{ac}(0.05-0.02)$ 


\section{DMD14. Sw/Horsetail \\ (Picea glauca/Equisetum arvense)}

$\mathbf{n = 5}$ This community type is wet and nutrient rich. These sites are commonly found on fluvial or glaciolacustrine parent materials where flooding or seepage enhances the substrate nutrient supply. With high water tables, wet soil conditions organic matter tends to accumulate which favours the growth of horsetails. Generally horsetails are unpalatable to livestock and the wet ground conditions limit access.

\section{Plant Composition Canopy Cover(\%)}

\section{Trees}

White Spruce

(Picea glauca)

BALSAM POPLAR

(Populus balsamifera)

PAPER BIRCH

(Betula papyrifera)

\section{SHRUBS}

PRICKLY ROSE

(Rosa acicularis)

RED OSIER DOGWOOD

(Cornus stolonifera)

BRACTED HONEYSUCKLE

(Lonicera involucrata)

LOW BUSH CRANBERRY

(Viburnum edule)

Forbs

DEWBERRY

(Rubus pubescens)

HORSETAIL

(Equisetum arvense)

BISHOP's CAP

(Mitella nuda)

BUNCHBERRY

(Cornus canadensis)

\section{MEAN RANGE CONST.}

$\begin{array}{lll}44 & 20-60 & 100 \\ 3 & 0-10 & 60 \\ 9 & 0-40 & 80\end{array}$

$3 \quad 1-10 \quad 100$

$3 \quad 0-10 \quad 80$

$1 \quad 0-3 \quad 80$

$1 \quad 0-3 \quad 60$

Grasses

MARSH REED GRASS

(Calamagrostis canadensis) 1

NODDING WOOD REED

(Cinna latifolia)

\section{ENVIRONMENTAL VARIABLES}

MOISTURE REgIME:

HYGRIC

NUTRIENT REgIME:

$\mathrm{RICH}$

ElEVATION:

$600 \mathrm{M}$

Soll DRAINAGE:

POOR TO MODERATELY WELL

ECOLOGICAL STATUS SCORE: 18

FORAGE PRODUCTION(KG/HA)

Total $\quad 560 *$ Estimate

ECOLOGICALLY SUSTAINABLE STOCKING RATE

$40.47 \mathrm{ha} / \mathrm{AUM}(40.47-40.47)$

0.01 AUM/ac (0.01-0.01) 


\section{CENTRAL MIXEDWOOD SUBREGION}




\section{CENTRAL MIXEDWOOD SUBREGION}

This subregion is the largest in the province covering over $210,000 \mathrm{~km}^{2}$ or nearly $32 \%$ of the province (Strong and Leggat 1992)( Map 2). Mean annual summer temperatures average $13.5^{\circ} \mathrm{C}$ and winter temperatures average $-13{ }^{\circ} \mathrm{C}$, which is somewhat colder than the adjacent Dry Mixedwood subregion. Annual precipitation averages $397 \mathrm{~mm}$ of precipitation which is wetter than the Dry Mixedwood.

The modal plant communities are vegetated by aspen and balsam poplar with understories composed of a variety of herbs and deciduous shrubs. White spruce and balsam fir are the climatic climax species but are not well represented because of the frequent occurrence of fire. On dry, well drained, coarse-textured soils jack pine dominates and the poorly drained sites are dominated by black spruce, willows and sedge species. These reference communities are very similar to the Dry Mixedwood subregion, but the drier conditions of the Dry Mixedwood favours the formation of a number of native grassland communities, which are not found in the Central Mixedwood. Table 6 outlines the ecological sites, ecological site phases and reference range plant community types in the Central Mixedwood subregion. There are a number of new ecological sites (ecosites) and ecological site phases (ecosite phases) which are not found in the guide "Ecosites of Northern Alberta" (Beckingham and Archibald 1996) and they are outlined here. The new ecosite includes (aa) grass/shrubland and the new ecosite phases include (aa1) plains wormwood, (d4)shrubland, (e4) shrubland, and (j3) grassland poor fen (Table 6). The "Successional communities" or "Harvesting and Fire succession" categories (Table 1 and 6 ) outline the successional sequence the community type will undergo with increased grazing pressure or with harvesting or fire disturbance. There are a number of ecological site phase tables which summarize these successional communities. These include (d1a) grazed Aw, (d1c) burned Aw, (d3c) burned Sw, and (k2a) grazed willow.

The 61 range plant communities described in the Central Mixedwood subregion are arranged into 5 categories. These include:

\section{Central Mixedwood subregion}
CMA. Native grass and shrubland
19 types
CMB. Tame pastures
7 types
CMC. Deciduous community types
19 types
CMD. Mixedwood and Conifer community types
12 types
CME. Forest Cutblock community types
4 types

The dominant plant species, canopy cover, environmental conditions, forage production and grazing capacity (when available) are outlined for each community type. 


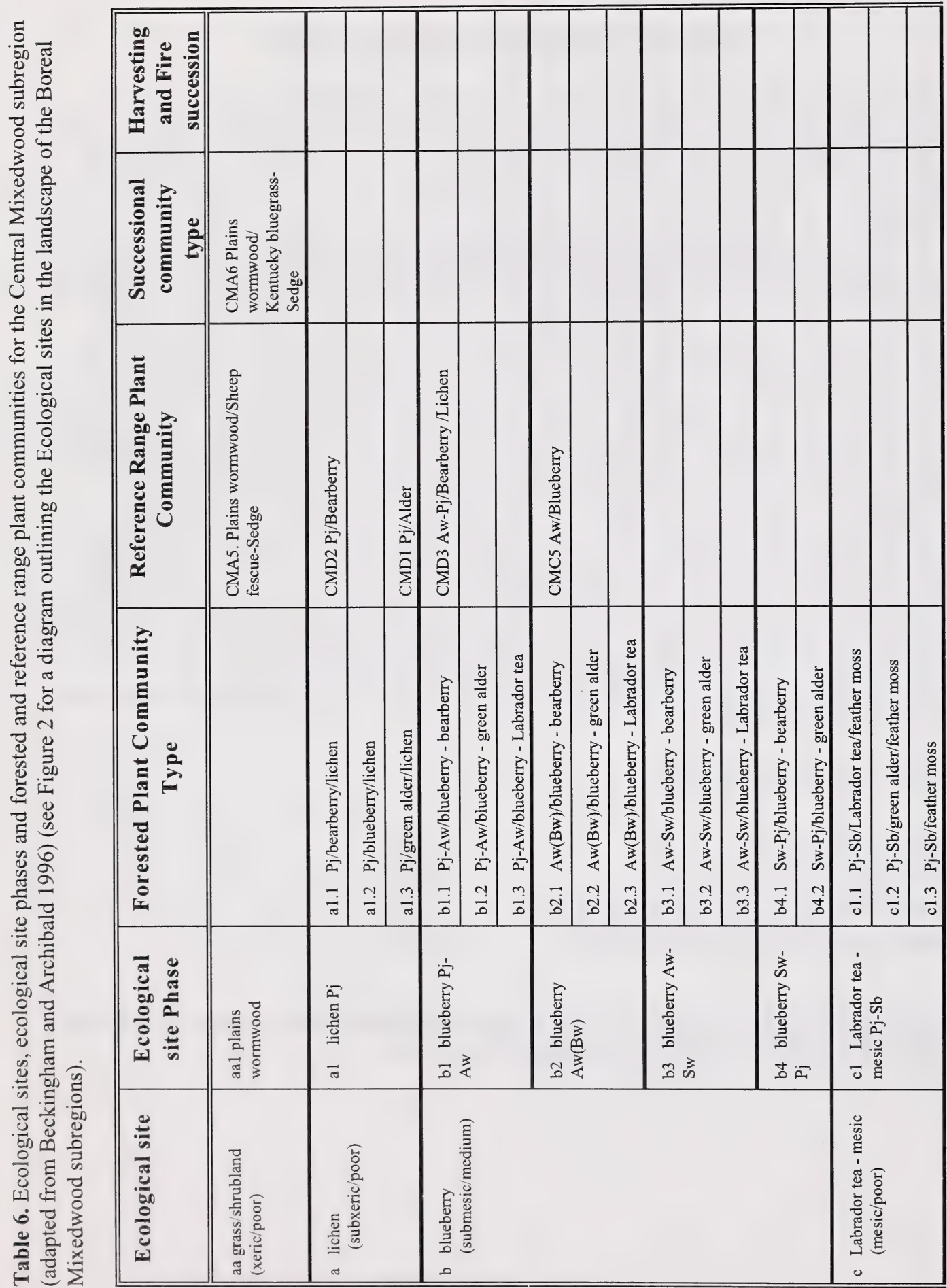




\begin{tabular}{|c|c|c|c|c|c|c|c|c|c|c|c|c|c|c|c|}
\hline 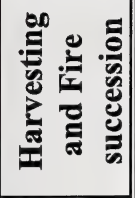 & & & 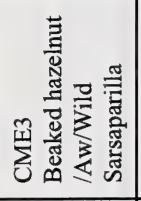 & & & 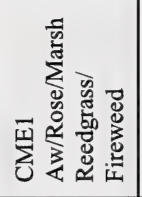 & & 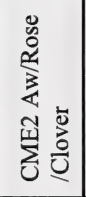 & & 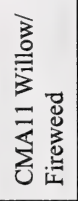 & & & & & \\
\hline 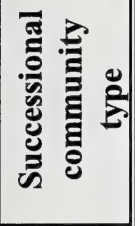 & & & & & 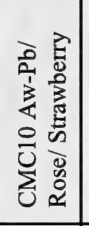 & 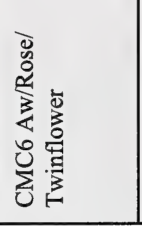 & 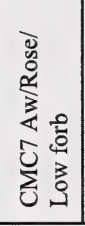 & 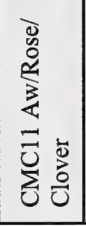 & 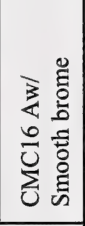 & & & & & & \\
\hline 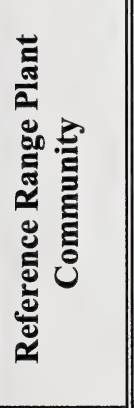 & 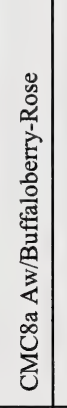 & 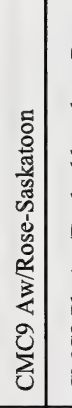 & 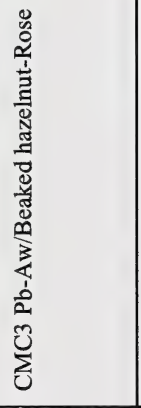 & 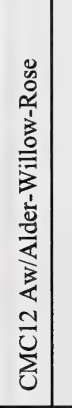 & & 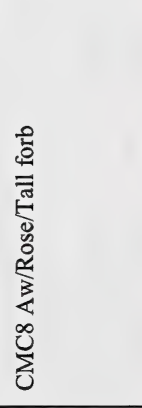 & & & & 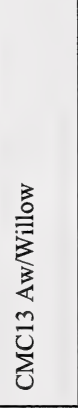 & & & 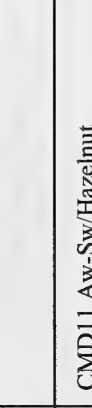 & & \\
\hline 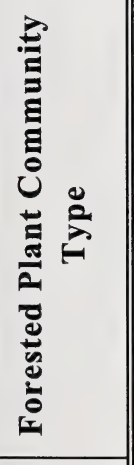 & 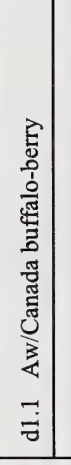 & 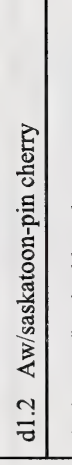 & 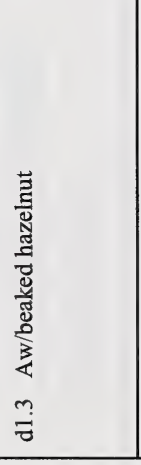 & 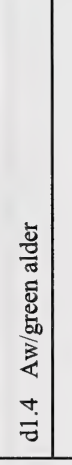 & 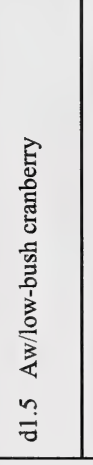 & 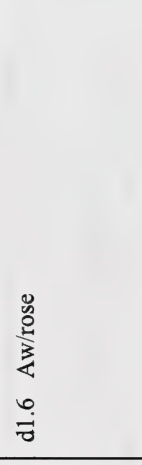 & & & & 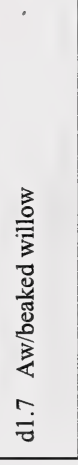 & 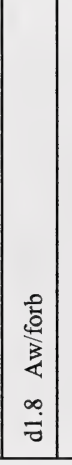 & 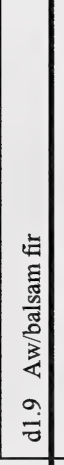 & 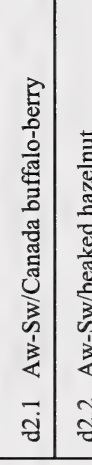 & 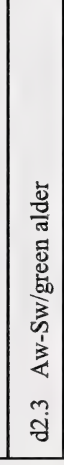 & 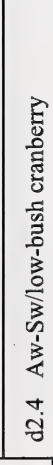 \\
\hline 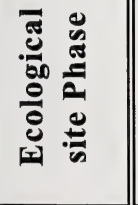 & 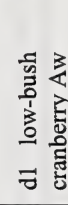 & & & & & & & & & & & & 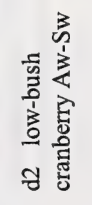 & & \\
\hline 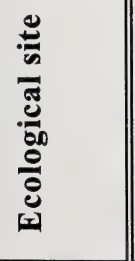 & 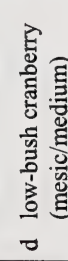 & & & & & & & & & & & & - & & \\
\hline
\end{tabular}




\begin{tabular}{|c|c|c|c|c|c|c|c|c|c|c|c|c|c|c|c|c|c|}
\hline 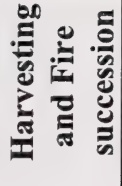 & & & & & & & 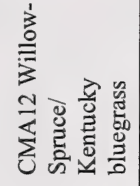 & & & & & 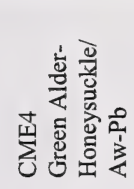 & & & & & \\
\hline 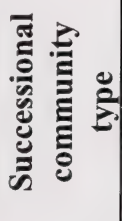 & & & & & & & & & 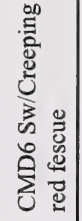 & 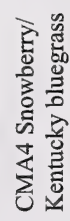 & & & & & & & \\
\hline 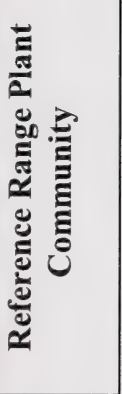 & 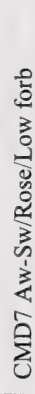 & & & & & & & 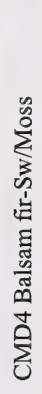 & 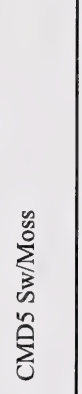 & 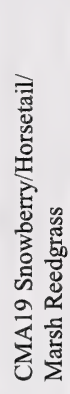 & 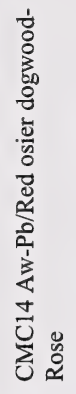 & 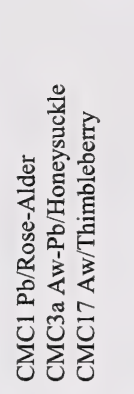 & 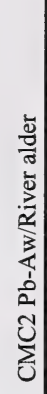 & & & & \\
\hline 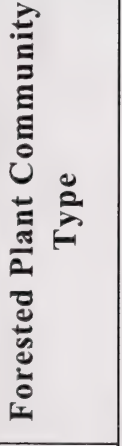 & 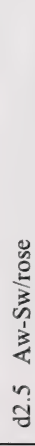 & 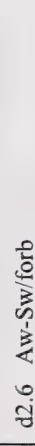 & 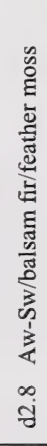 & 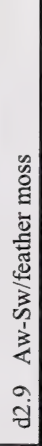 & 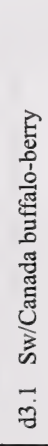 & 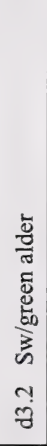 & 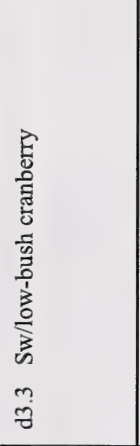 & 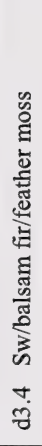 & 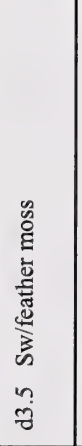 & & 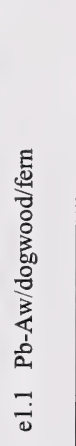 & 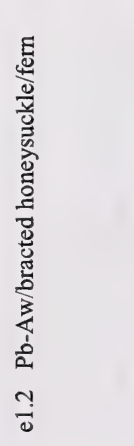 & 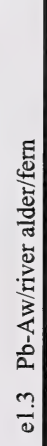 & 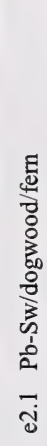 & 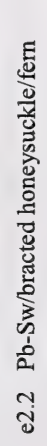 & 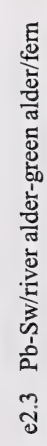 & 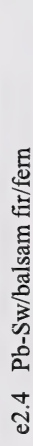 \\
\hline 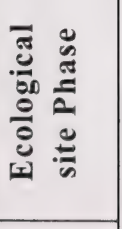 & & & & & 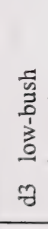 & & & & & 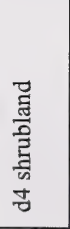 & $\begin{array}{l}3 \\
4 \\
0 \\
0 \\
0 \\
0 \\
0 \\
0 \\
0 \\
0 \\
0 \\
-1\end{array}$ & & & 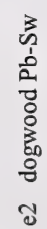 & & & \\
\hline 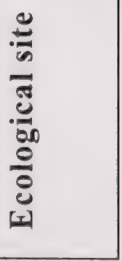 & & & & & & & & & & & 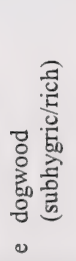 & & & & & & \\
\hline
\end{tabular}




\begin{tabular}{|c|c|c|c|c|c|c|c|c|c|c|c|c|}
\hline 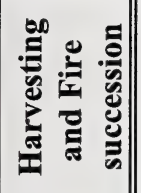 & & & & & & & & & & & & \\
\hline 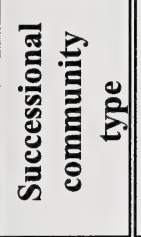 & & & & 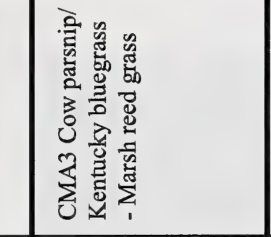 & & & & & & & & \\
\hline 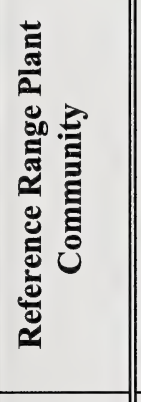 & & & & 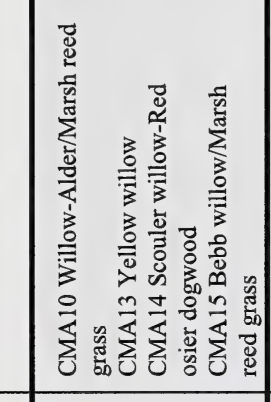 & 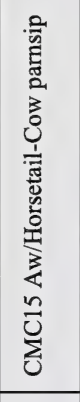 & & 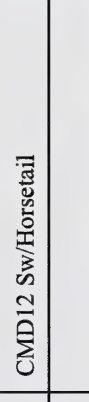 & & 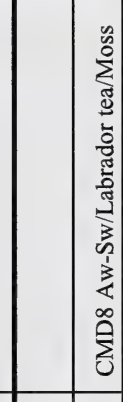 & 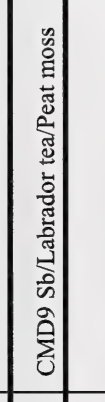 & & 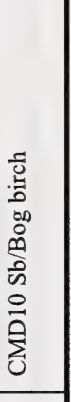 \\
\hline 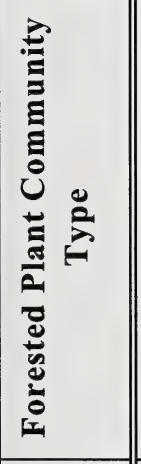 & 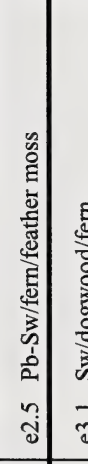 & 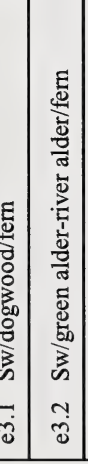 & 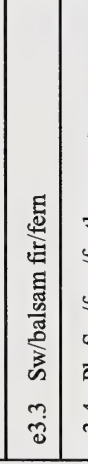 & 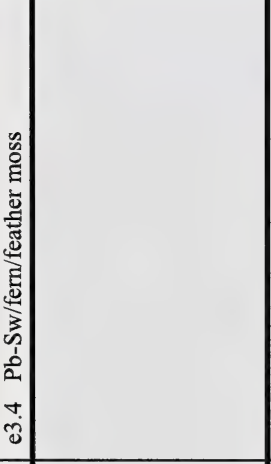 & 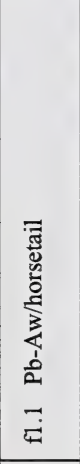 & 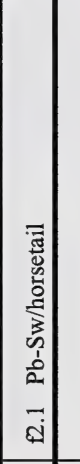 & 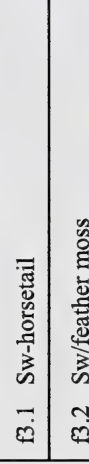 & 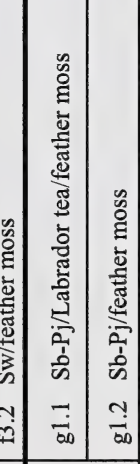 & 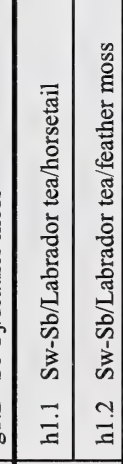 & 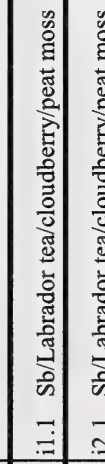 & |ٕ: & 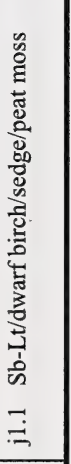 \\
\hline 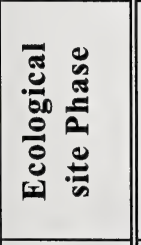 & & 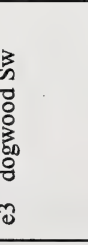 & & 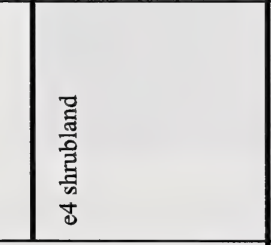 & 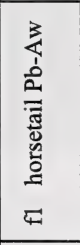 & 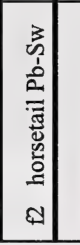 & 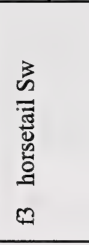 & 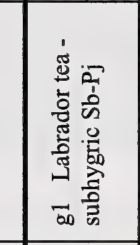 & 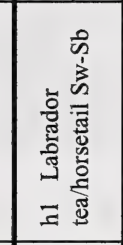 & 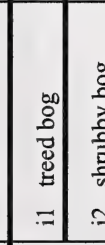 & 豙. & 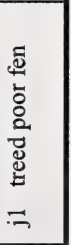 \\
\hline 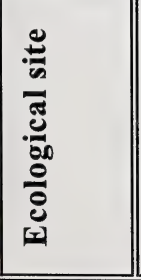 & & & & & 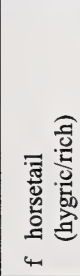 & & & \begin{tabular}{|l} 
\\
\\
\end{tabular} & 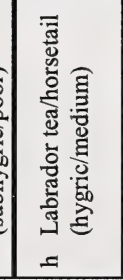 & 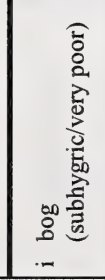 & & \\
\hline
\end{tabular}




\begin{tabular}{|c|c|c|c|c|c|c|c|c|c|c|c|}
\hline 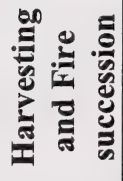 & & & & & & & & & & & \\
\hline 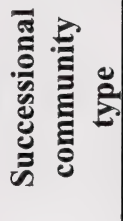 & & & & & 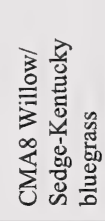 & & & & & & \\
\hline 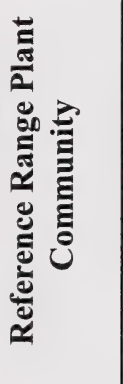 & 竞 & 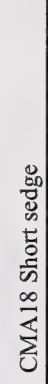 & & & 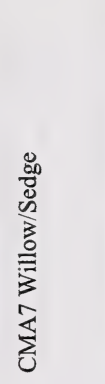 & 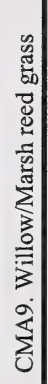 & 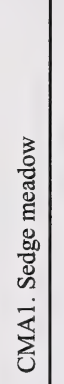 & 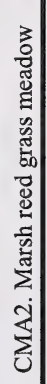 & & 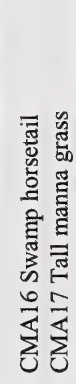 & \\
\hline 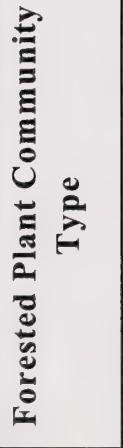 & 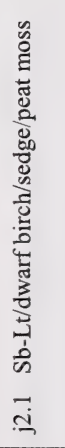 & & 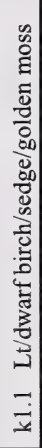 & 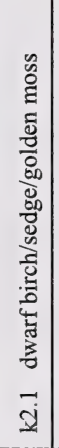 & 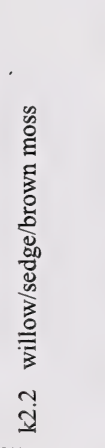 & 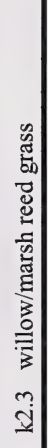 & 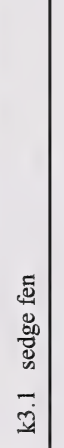 & 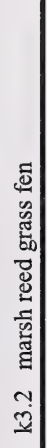 & 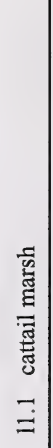 & 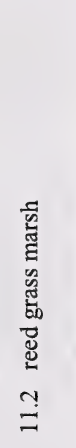 & 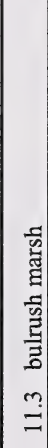 \\
\hline 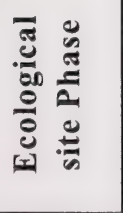 & 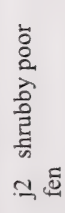 & 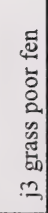 & 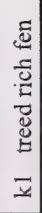 & 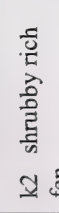 & & & 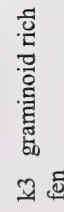 & & 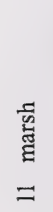 & & \\
\hline 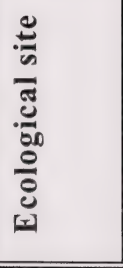 & & & 플 & & & & & & $\begin{array}{r}5 \\
- \\
\end{array}$ & $\underset{0}{0}$ & \\
\hline
\end{tabular}




\title{
CENTRAL MIXEDWOOD SUBREGION
}

\author{
GRASSLAND AND SHRUBLAND COMMUNITY TYPES
}

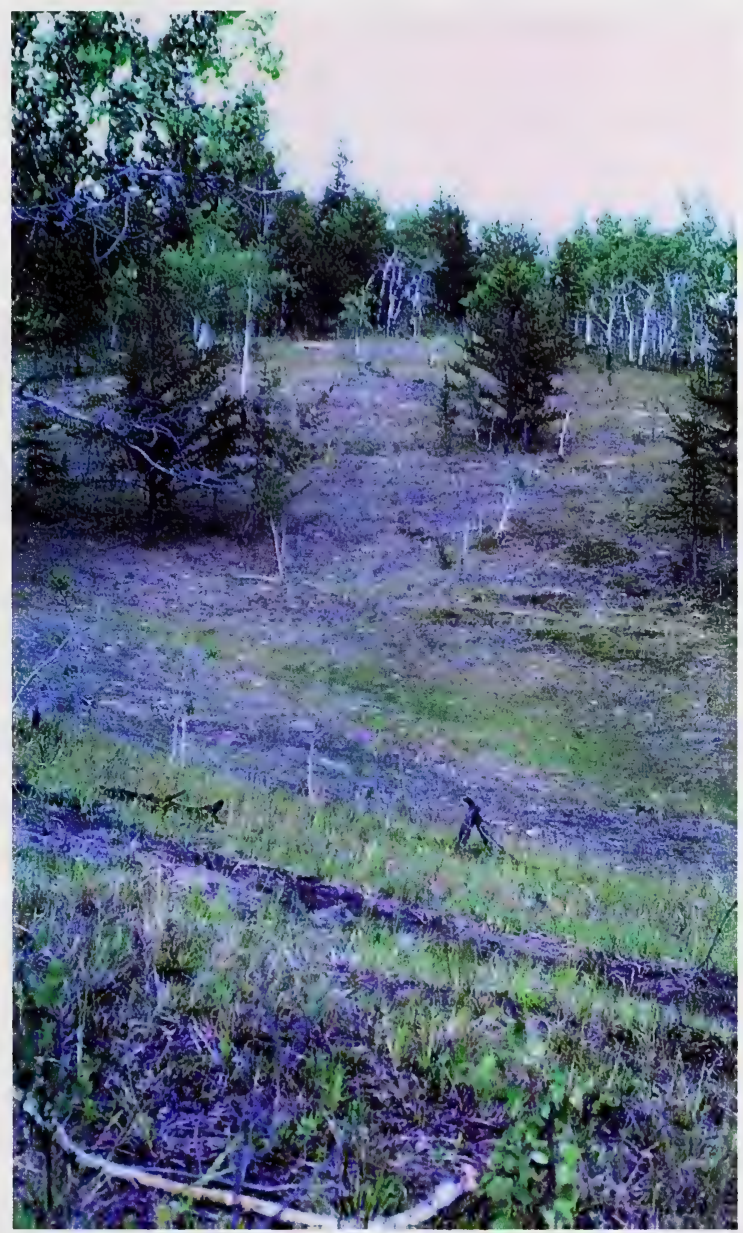

Photo 7. This picture represents the Plains wormwood/Sheep fescue-Sedge community type. This community type is common on dry sandy hills throughout the Central Mixedwood subregion. 


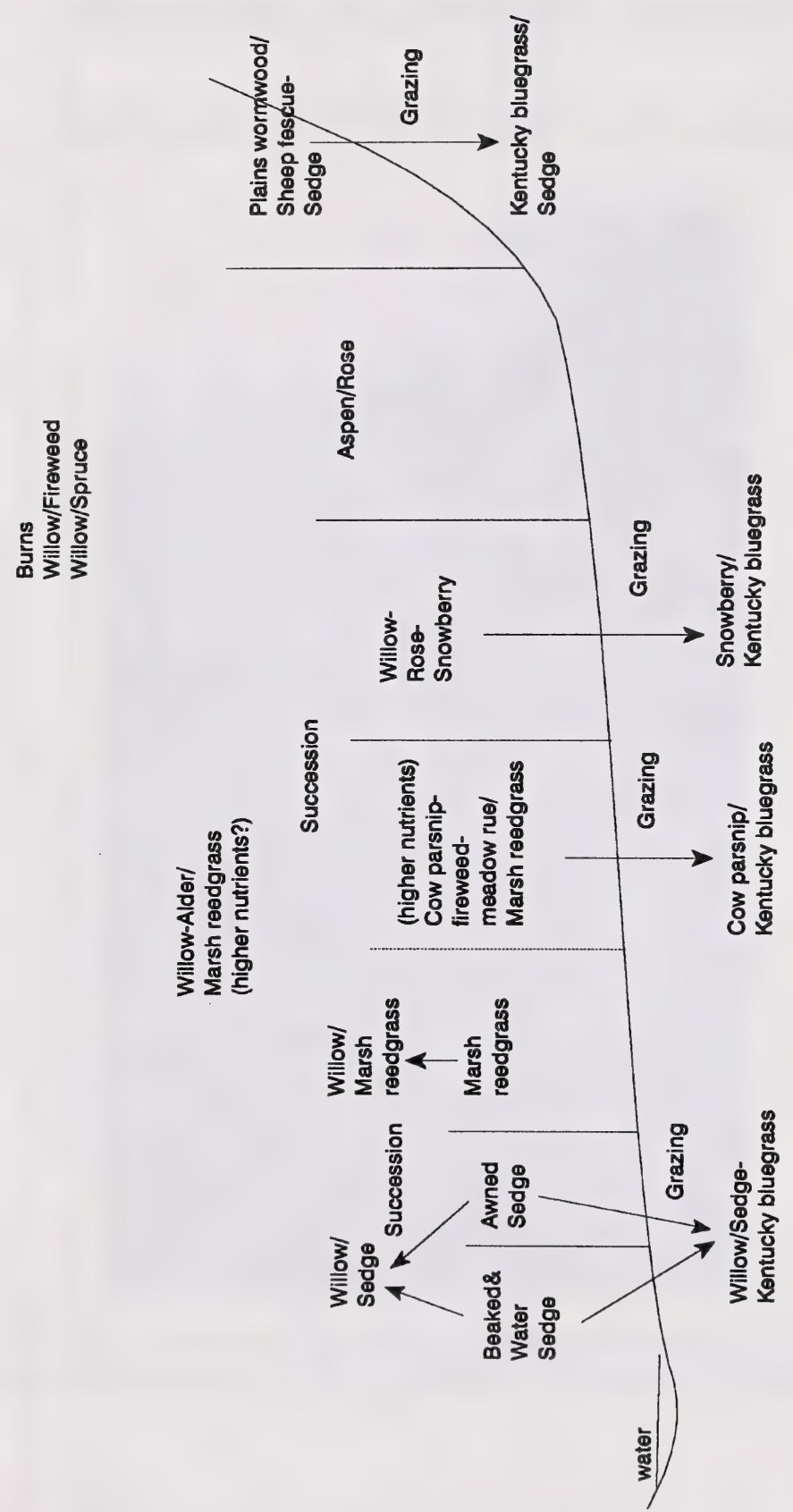

Figure 8. Ecology of the native grass and shrublands of the Central Mixedwood subregion. 


\section{NATIVE GRASS AND SHRUBLAND COMMUNITIES}

Upland native grasslands are very rare in the Central Mixedwood subregion. The communities that have been described occur on coarse textured, sandy soil, with xeric to subxeric moisture and poor nutrient regimes which lack tree cover. This includes the Plains wormwood/Sheep fescueSedge community type. This community type is usually found in association with jack pine dominated community types. Heavy grazing of this community type can lead to a Kentucky bluegrass-Sedge/Plains wormword dominated type on slightly moister sites. On level, gravelly, welldrained sites adjacent to streams and rivers the Snowberry/Horsetail/Marsh Reedgrass community type is common. This community is extensively grazed by livestock to form the Snowberry/Kentucky bluegrass dominated type (Figure 3).

Wetter (subhydric/rich) sites are associated with sedge, swamp horsetail, tall manna grass and marsh reed grass dominated meadows. Sedge and swamp horsetail species are usually associated with the areas of free standing water, whereas, tall manna grass and marsh reed grass dominate the better drained, drier edges. Willow will invade into these meadows to form the Willow/Sedge and Willow/Marsh reed grass community types. Under grazing pressure these community types tended to be invaded by dandelion, clover and Kentucky bluegrass to form the Willow/Sedge-Kentucky bluegrass community type.

Fire is an important part of the ecology of the Central Mixedwood subregion. There are a number of shrubland community types which have a strong fire origin. These include the Willow-River alder/Marsh reed grass, Willow/Fireweed and Willow-Spruce/ Kentucky bluegrass dominated community types. Other upland shrub communities which are found on nutrient rich, seepage areas include the Scouler and Bebb willow dominated communities. 


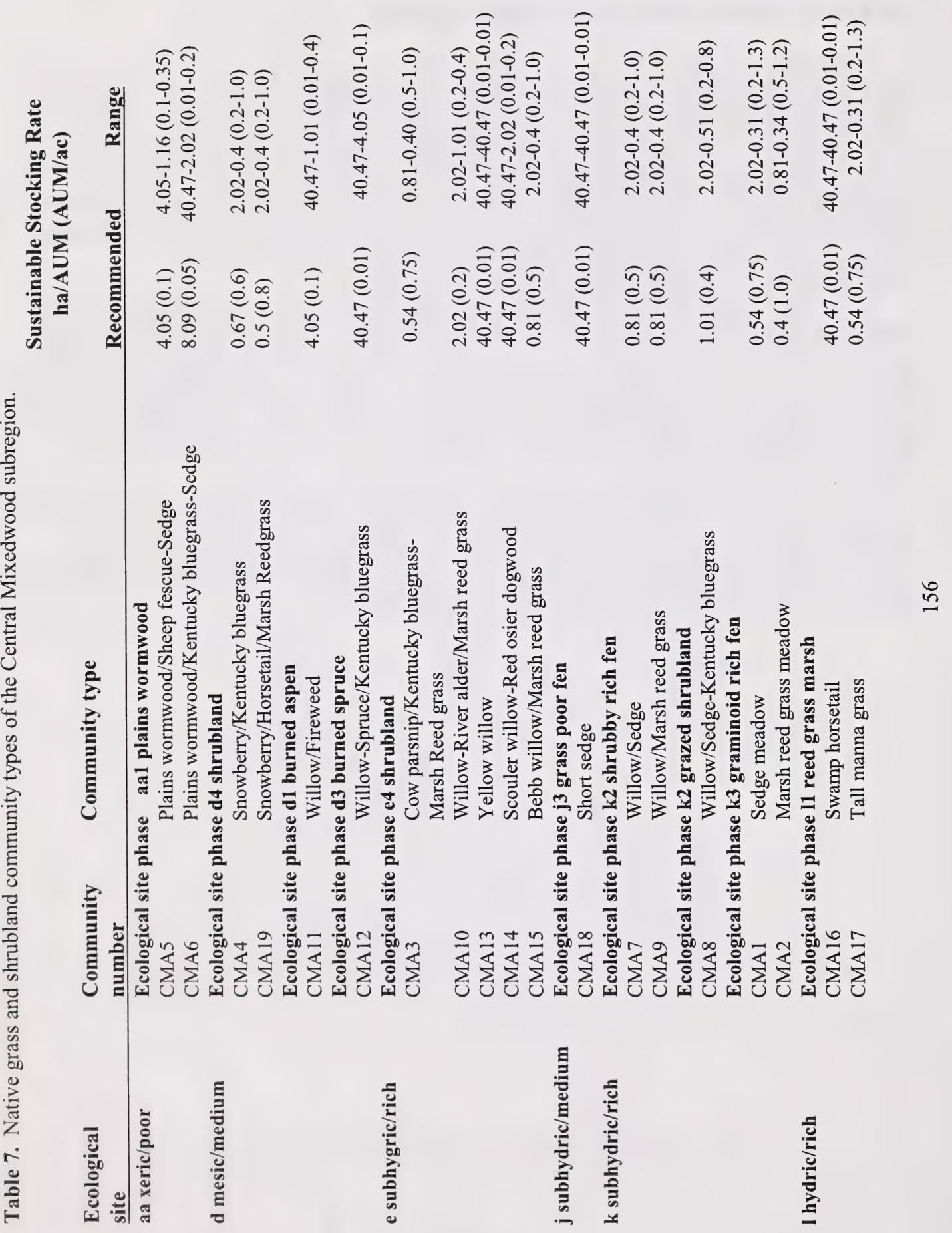


Key to Central Mixedwood Grass and Shrublands

1. Shrubland dominated by willow, bog birch, alder, understory spruce.................................2

Grass-dominated, or if shrub-dominated, upland species like snowberry.........................7

\section{SHRUBLANDS}

2. Sedge, marsh reed grass dominated understory, wet sites or riparian or seepage areas dominated by yellow, Scouler or Bebb willow. $3 a$

Communities of fire origin, willow, alder, fireweed, understory spruce dominated .............5

3. Ungrazed, sedge and marsh reed grass dominated understory........................................4 Grazed community type with Kentucky bluegrass... Willow/Sedge-Kentucky Bluegrass (CMA8)

3a. Riparian areas dominated by yellow willow. Yellow willow(CMA13)

Seepage areas dominated by Bebb or Scouler's willow or edges of lakes and sloughs dominated by Marsh reed grass or sedge in understory...

3b. Upland seepage areas dominated by Bebb or Scouler's willow.

Wet lowland sites dominated by Marsh reed grass or sedge species.

4. Wetland sedges dominate understory. Willow/Sedge (CMA7) Marsh reed grass dominates understory. .Willow/Marsh Reed grass (CMA9)

4a. Bebb willow dominated community. .Bebb willow/Marsh reed grass(CMA15) Scouler's willow dominated community......Scouler willow-Red osier dogwood(CMA14)

5. Willow, alder dominated community. .Willow-Alder/Marsh Reed grass (CMA10) Willow, fireweed and understory spruce dominated communities.

6. Willow, fireweed dominated. Willow/Fireweed (CMA11) Willow, spruce dominated.

\section{GRASSLANDS}

7. Lowland sites dominated by sedge, marsh reed grass, swamp horsetail or tall manna grass. $7 \mathrm{a}$

Upland sites dominated by snowberry, sage, or cow parsnip.

7a. Boggy areas dominated by short sedge.....

Short sedge (CMA18)

Freshwater areas dominated by marsh reed grass, sedge, swamp horsetail or tall manna grass...7b

7b. Area dominated by sedge or Marsh reed grass. 8

Area dominated by tall manna grass or swamp horsetail. $.7 \mathrm{c}$

7c. Swamp horsetail dominated site, very wet. .Swamp horsetail (CMA16)

Tall manna grass dominated site Tall manna grass (CMA17)

8. Wet sites dominated by wetland sedge. Sedge Meadow (CMA1) Slightly drier sites dominated by marsh reed grass .Marsh Reed grass Meadow (CMA2)

9. Moist, nutrient rich seepage areas or snowberry dominated areas adjacent to rivers. 10 Dry, sandy sites or south facing slopes dominated by sage or grasses and upland sedge.....11

10. Moist nutrient rich seepage areas dominated by cow parsnip. Cow Parsnip/Kentucky Bluegrass-Marsh Reed grass (CMA3)

Well drained, gravelly sites adjacent to rivers and dominated by snowberry.

11. Dry, sandy south facing slopes dominated by plains wormwood, sheep fescue, and sedge .Plains Wormwood/Sheep Fescue-Sedge (CMA5) Grazed, sandy grasslands dominated by Kentucky bluegrass.

\section{.Plains Wormwood/Kentucky Bluegrass-Sedge (CMA6)}

12. Ungrazed to moderately grazed sites dominated by snowberry and marsh reegrass.

..Snowberry/Horsetail/Marsh Reedgrass (CMA19)

Heavily grazed sites dominated by Kentucky bluegrass and dandelion. 


\section{CMA1. Sedge meadows \\ (Carex aquatilis, C. rostrata, C. atherodes)}

$\mathbf{n = 5} \quad$ This wetland community type is found near fresh water. The sedge meadow is a poorly drained community. As one moves to the drier edges marsh reed grass becomes predominant. Willows will invade into both the sedge and marsh reed grass dominated meadows. The sedge meadow community is very productive, but the high water table, particulary in the spring when the sedge species are most palatable, restricts livestock movement. One study done in the Yukon found that crude protein on these meadows declined from a high of $10 \%$ in May to less than $5 \%$ in September (Bailey et al. 1992).

Beaked sedge found in abundance in this community is usually associated with nitrogen rich conditions and moving water (Brierly et al. 1985). Water sedge is often found in abundance in this community type and is associated with calcium rich stagnant water (MacKinnon et al. 1992).

\section{Plant Composition Canopy Cover(\%) MEAN RANGE CONST.}

\section{FORBS}

MARSH SKULLCAP

(Scutellaria galericulata)
NODDING BEGGAR TICKS

(Bidens cernua)

DANDELION

(Taraxacum officinale)

$\begin{array}{lll}5 & 0-25 & 20 \\ 3 & 0-13 & 20 \\ 1 & 0-3 & 20\end{array}$

\section{Grasses}

BEAKED SEDGE

(Carex rostrata)

AWNED SEDGE

(Carex atherodes)

WATER SEDGE

(Carex aquatilis)

MARSH REED GRASS

(Calamagrostis canadensis)

$13 \quad 0-57 \quad 40$

$\begin{array}{lll}3 & 0-7 & 100\end{array}$

$8 \quad 0-18 \quad 60$

\section{ENVIRONMENTAL VARIABLES}

MoISTURE REgIME (MEAN):

SUBHYDRIC-HYGRIC

NUTRIENT REGIME (MEAN

RICH

ELEVATION:

$150-606(485) \mathrm{M}$

SoIL DRAINAGE (MEAN):

POORLY TO VERY POORLY

ECOLOGICAL STATUS SCORE: 24

HEALTH FORM: RIPARIAN

FORAGE PRODUCTION(KG/HA) $n=5$

$\begin{array}{ll}\text { GRASS } & 2209(1498-300) \\ \text { FORB } & 161(0-644) \\ \text { TOTAL } & 2370(1498-3000)\end{array}$

ECOLOGICALLY SUSTAINABLE STOCKING RATE

GENERALLY NON-USE

$0.54 \mathrm{ha} / \mathrm{AUM}(2.02-0.31)$

$0.75 \mathrm{AUM} / \mathrm{ac}(0.2-1.3)$ 


\section{CMA2. Marsh reed grass meadow \\ (Calamagrostis canadensis)}

$\mathbf{n}=\mathbf{6}$ This community is found on the edges of sedge meadows and moist draws where the water table is lower. The lower water table makes this community accessible for most of the grazing season. Willow will invade onto these sites to form the Willow/Marsh reed grass community type. Increased grazing pressure on these sites will cause marsh reed grass to decline and their will be an invasion of Kentucky bluegrass and dandelion. These sites are highly productive for domestic livestock and should be rated as primary range.

\section{Plant Composition Canopy Cover(\%) \\ MEAN RANGE CONST.}

TREES

WHITE BIRCH

(Betula papyrifera)

2

$0-14 \quad 17$

SHRUBS

WILLOW SPP.

(Salix spp.)

FORBS

NODDING BEGGARTICKS

(Bidens cernua)

LEAFY-BRACTED ASTER

(Aster sibricus)

DOCK, SORREL

(Rumex crispus)

Grasses

MARSH REED GRASS

(Calamagrostis canadensis) $\quad 56 \quad 34-83 \quad 100$

BEAKED SEDGE

(Carex rostrata)

WATER SEDGE

(Carex aquatilis)

AWNED SEDGE

(Carex atherodes)

\section{ENVIRONMENTAL VARIABLES}

MOISTURE REGIME (MEAN): HYGRIC

NUTRIENT REgIME (MEAN): MEDIUM TO RICH

ELEVATION: $150-758(320) \mathrm{M}$

SoIL DRAINAGE (MEAN): POORLY

ECOLOGICAL STATUS SCORE: 24

HEALTH FORM: RIPARIAN

Forage Production(Kg/Ha) $\mathrm{n}=6$

GRASS 2068(1052-5110)

FORB 6(0-18)

SHRUB $\quad 42(0-254)$

TOTAL 2117(1070-5110)

ECOLOGICALLY SUSTAINABLE STOCKING RATE $0.4 \mathrm{ha} / \mathrm{AUM}(0.81-0.34)$ $1.0 \mathrm{AUM} / \mathrm{ac}(0.5$ - 1.2$)$ 


\section{CMA3. Cow parsnip/Kentucky bluegrass-Marsh reed grass (Heracleum lanatum/Poa pratensis-Calamagrostis canadensis)}

$\mathbf{n = 1}$ This community type is found on fine textured, silty soils adjacent to the Willow river near Wabasca. It represents a Willow/Cow parsnip/Marsh reed grass community that has been cleared and then grazed extensively. The heavy grazing pressure has allowed dandelion and Kentucky bluegrass to invade onto the site. The high nutrient and moisture regime of this community type makes it extremely productive. Once cleared of shrubs it can provide a significant amount of forage for domestic livestock.

\section{Plant Composition Canopy Cover(\%) MEAN RANGE CONST.}

\section{SHRUBS}

GREEN ALDER

(Alnus crispa)

PRICKLY ROSE

(Rosa acicularis)

FORBS

COW PARSNIP

(Heracleum lanatum) $\quad 42 \quad-\quad 100$

HORSETAIL

(Equisetum arvense) $\quad 33 \quad-\quad 100$

DANDELION

(Taraxacum officinale)

FIREWEED

(Epilobium angustifolium)

CREamy Peavine

(Lathyrus ochroleucus)

Grasses

KENTUCKy BLUEgRASS

(Poa pratensis)

MARSH REED GRASS

(Calamagrostis canadensis)

FRINGED BROME

(Bromus ciliatus)

$\begin{array}{lll}1 & - & 100 \\ & 8 & -10 \\ 42 & - & 100 \\ 33 & - & 100 \\ 27 & - & 100 \\ 19 & - & 100 \\ 8 & - & 100 \\ 15 & - & 100 \\ 10 & - & 100 \\ 2 & - & 100\end{array}$

\section{ENVIRONMENTAL VARIABLES}

MoISTURE REGIME (MEAN): SUBHYGRIC

Nutrient Regime (MEAN): $\mathrm{RICH}$

ELEVATION: $606 \mathrm{M}$

Soll Drainage (MEAN): MODERATELY WELL

ECOLOGICAL STATUS SCORE: $16-8$

HEALTH FORM: RIPARIAN

Forage Production(Kg/Ha) $n=1$

$\begin{array}{ll}\text { GRASS } & 200 \\ \text { FORB } & 1798 \\ \text { SHRUB } & 470 \\ \text { TOTAL } & 2468\end{array}$

ECOLOGICALLY SUSTAINABLE STOCKING RATE 0.54 ha/AUM $(0.81-0.40)$ $0.75 \mathrm{AUM} / \mathrm{ac}(0.5-1.0)$ 


\section{CMA4. Snowberry/Kentucky bluegrass \\ (Symphoricarpos occidentalis/Poa pratensis)}

$\mathbf{n = 4}$ This snowberry dominated community type appears to be common on level, well drained, gravelly areas along rivers throughout Northern Alberta. In the absence of disturbance this community type appears to be dominated by snowberry, rose, fireweed, slender wheat grass and marsh reed grass. Heavy grazing pressure causes the native forbs and grasses to decline and allows Kentucky bluegrass, dandelion and clover to increase. Because these clearings are some of the only natural openings throughout the Central Mixedwood they tend to be heavily utilized by livestock. Snowberry which is unpalatable to livestock will remain even under extreme grazing pressure.

\section{Plant Composition Canopy Cover(\%)}

MEAN RANGE CONST.

\section{SHRUBS}

PRICKLY ROSE

(Rosa acicularis)

BUCKBRUSH

(Symphoricarpos

occidentalis)

WILLOW

(Salix spp.)

FORBS

STRAWBERRY

(Fragaria virginiana)

Clover

(Trifolium repens)

DANDELION

(Taraxacum officinale)

YARROW

(Achllea millefolium)

AMERICAN VETCH

(Vicia americana)

Grasses

MARSH REED GRASS

(Calamagrostis canadensis)

SLENDER WHEAT GRASS

(Agropyron trachycaulum)

KENTUCKY BLUEGRASS

(Poa pratensis)

PRAIRIE SEDGE

(Carex prairea)

$3 \quad 0-9 \quad 50$

$19 \quad 1-30 \quad 100$

$5 \quad 0-8 \quad 75$

$1 \quad 0-1 \quad 75$

$32 \quad 5-49 \quad 100$

$2 \quad 1-4 \quad 100$

$1 \quad 0-1 \quad 50$

$7 \quad 0-24 \quad 50$

$\begin{array}{lll}7 & 3-13 & 100\end{array}$

$38 \quad 16-73 \quad 100$

$1 \quad 0-1 \quad 25$
$29 \quad 0-54 \quad 75$

\section{ENVIRONMENTAL VARIABLES}

MoISTURE REGIME (MEAN): MEsiC

NUTRIENT REGIME (MEAN): MEDIUM TO RICH

ELEVATION: 576-606 (586) M

SOIL DRAINAGE (MEAN):

WELL

ECOLOGICAL STATUS SCORE: 8 - 0

\section{Forage Production(Kg/Ha) $n=4$}

$\begin{array}{ll}\text { GRASS } & 1337(800-1800) \\ \text { FORB } & 1311(200-2390) \\ \text { SHRUB } & 141(0-424) \\ \text { TOTAL } & 2790(2000-3614)\end{array}$

ECOLOGICALLY SUSTAINABLE STOCKING RATE $0.67 \mathrm{ha} / \mathrm{AUM}(2.02-0.4)$ $0.6 \mathrm{AUM} / \mathrm{ac}(0.2-1.0)$ 


\section{CMA5. Plains wormwood/Sheep fescue-Sedge (Artemisia campestris/Festuca saximontana-Carex spp.)}

$\mathbf{n = 3}$ This community type is found on coarse textured, sandy soils. It is generally found on hilltops and southfacing slopes in openings among Jack pine on the uplands and black spruce in the lowlands. This community type was also described on similar site conditions in the Dry Mixedwood subregion. This community would be considered either secondary or non-use range for domestic livestock because of the low forage production and fragile nature of the community.

\section{Plant Composition Canopy Cover(\%)}

MEAN RANGE CONST.

\section{SHRUBS}

SASKATOON

$\begin{array}{llll}\text { (Amelanchier alnifolia) } & 3 & 1-3 & 100\end{array}$

BLUEBERRY

(Vaccinium myrtilloides)

FORBS

SMOOTH SCOURING RUSH

(Equisetum laevigatum)

PLAINS WORMWOOD

(Artemisia campestris)

LOW GOLDENROD

(Solidago missouriensis)

BEARBERRY

(Arctostaphylos uva-ursi)

Grasses

KENTUCKY BLUEGRASS

(Poa pratensis)

NORTHERN RICEGRASS

(Oryzopsis pungens)

SLENDER WHEAT GRASS

(Agropyron trachycaulum)

SEDGE

(Carex spp)

SHEEP FESCUE

(Festuca saximontana)

\section{ENVIRONMENTAL VARIABLES}

MoISTURE REGIME (MEAN): SUBMESIC-SUBXERIC

NUTRIENT REgIME (MEAN): MEDIUM

ELEVATION: 576-652 (611) M

SoIl DRAINAGE (MEAN): RAPIDLY

Slope(RANGE): $22(15-30) \%$

ASPECT:

SOUTH TO WESTERLY

ECOLOGICAL STATUS SCORE: 24

Forage Production(KG/Ha) $n=3$

$\begin{array}{ll}\text { GraSS } & 469(270-612) \\ \text { FORB } & 303(200-452) \\ \text { TOTAL } & 772(470-978)\end{array}$

ECOLOGICALLY SUSTAINABLE STOCKING RATE $4.05 \mathrm{ha} / \mathrm{AUM}(4.05-1.16)$ 0.1 AUM/ac (0.1 - 0.35) 


\section{CMA6. Plains wormwood/Kentucky bluegrass-Sedge}

\section{(Artemisia campestris/Poa pratensis-Carex spp.)}

$\mathbf{n = 1}$ This community type is similar to the Plains wormwood/Sheep fescue-Sedge community type, but heavy grazing pressure and a higher nutrient and moisture regime has allowed Kentucky bluegrass to invade onto the site.

\section{Plant Composition Canopy Cover(\%)}

\section{SHRUBS}

SASKATOON

(Amelanchier alnifolia)

CHOKECHERRY

(Prunus virginiana)

SNOWBERRY

(Symphoricarpos

occidentalis)

FORBS

MEADOW PARSNIP

(Zizia aptera)

PLAINS WORMWOOD

(Artemisia campestris)

LOW GOLDENROD

(Solidago missouriensis)

BEARBERRY

(Arctostaphylos uva-ursi)

Grasses

MEAN RANGE CONST.

KENTUCKY BLUEGRASS

(Poa pratensis)

NORTHERN RICEGRASS

(Oryzopsis pungens)

SLENDER WHEAT GRASS

(Agropyron trachycaulum)

SEDGE

(Carex spp)

SHEEP FESCUE

(Festuca saximontana)

2

2

100

$8 \quad-\quad 100$

$3 \quad-\quad 100$

2

100

4

$4-\quad 100$

2

$10 \quad-\quad 100$

$49 \quad-\quad 100$

$4 \quad-\quad 100$

$3 \quad-\quad 100$

$13 \quad 100$

$1 \quad-\quad 100$

\section{ENVIRONMENTAL VARIABLES}

MoIsTURE REgIME (MEAN): SUBMESIC

NUTRIENT REGIME (MEAN): MEDIUM

Elevation: $606 \mathrm{M}$

SoIL DRAINAGE (MEAN): RAPIDLY

Slope(RAnge): $15 \%$

ASPECT:

SOUTH TO WESTERLY

ECOLOGICAL STATUS SCORE: 8

Forage Production(Kg/Ha) $n=1$

$\begin{array}{ll}\text { Grass } & 824 \\ \text { ForB } & 38 \\ \text { TOTAL } & 862\end{array}$

ECOLOGICALLY SUSTAINABLE STOCKING RATE $8.09 \mathrm{ha} / \mathrm{AUM}(40.47-2.02)$ 0.05 AUM/ac $(0.01-0.2)$ 


\section{CMA7. Willow/Sedge \\ (Salix spp./Carex spp.)}

$\mathbf{n}=\mathbf{7} \quad$ This community type is found along the edges of sedge meadows and in moist depressions. Willow becomes established at the edges of the sedge meadows due to the shorter duration of standing water. Increased flooding and prolonged waterlogging may result in the disappearance of willow and a transition to a water sedge meadow.

These sites are fairly productive but difficult to graze due to the moist ground conditions and heavy shrub cover which reduces access and mobility within the area.

\section{Plant Composition CanopyCover(\%)}

MEAN RANGE CONST.

\section{SHRUBS}

WILLOW SPP.

(Salix spp.)

$54 \quad 26-85 \quad 100$

\section{FORBS}

MINT

(Mentha arvensis)

GREEN SOREL

(Rumex acetosa)

FIREWEED

(Epilobium angustifolium) 2

HORSETAIL

(Equisetum arvense)

\section{GRASSES}

AWNED SEDGE

(Carex atherodes)

MARSH REED GRASS

(Calamagrostis canadensis) 10

BEAKED SEDGE

(Carex rostrata)

WATER SEDGE

(Carex aquatilis)

$\begin{array}{ccc}11 & 0-31 & 43 \\ 9 & 0-24 & 57 \\ 21 & 0-64 & 57\end{array}$

\section{ENVIRONMENTAL VARIABLES}

MOISTURE REGIME (MEAN): SUBHYDRIC

NUTRIENT REgIME (MEAN): RICH

ELEVATION:

$150-853(343) \mathrm{M}$

SoIl DRAINAGE (MEAN): POORLY

ECOLOGICAL STATUS SCORE: 24 or 18

HEALTH FORM: RIPARIAN

Forage Production(Kg/Ha) n=7

$\begin{array}{ll}\text { GRASS } & 1389(0-1734) \\ \text { FORB } & 152(70-3518) \\ \text { SHRUB } & 71(0-364) \\ \text { TOTAL } & 1612(214-4826)\end{array}$

ECOLOGICALLY SUSTAINABLE STOCKING RATE $0.81 \mathrm{ha} / \mathrm{AUM}(2.02-0.40)$ $0.5 \mathrm{AUM} / \mathrm{ac}(0.2-1.0)$ 


\section{CMA8. Willow/Sedge-Kentucky bluegrass \\ (Salix spp./Carex spp.-Poa pratensis)}

$\mathbf{n = 4}$ This community type is very similar to the Willow/Sedge community, but has been heavily grazed favouring the growth of Kentucky bluegrass and dandelion. Continued heavy grazing pressure will eventually lead to a community that is similar to the Kentucky bluegrass/Dandelion dominated community type.

\section{Plant Composition Canopy Cover(\%)}

MEAN RANGE CONST.

\section{SHRUBS}

WILLOW SPP.

(Salix spp.)

PRICKLY ROSE

(Rosa acicularis)

25

$\begin{array}{ll}1-40 & 100 \\ 3 & 0-10 \\ 25 & \end{array}$

\section{FORBS}

STRAWBERRY

$\begin{array}{llll}\text { (Fragaria virginiana) } & 3 & 0-11 & 25\end{array}$

DANDELION

(Taraxacum offincinale) $5 \quad 0-19 \quad 25$

MINT

(Mentha arvensis)

Clover

(Trifolium spp.)

ARROW LEAVED COLTSFOOT

(Petasites sagittatus) 9

Grasses

SEDGE

(Carex rostrata, aquatilis atherodes.)

KENTUCKY BLUEGRASS

(Poa pratensis)
$40 \quad 12-61 \quad 100$

$3 \quad 0-6 \quad 75$

$9 \quad 0-44 \quad 25$

$0-15 \quad 50$

$21 \quad 7-42 \quad 100$

\section{ENVIRONMENTAL VARIABLES}

MOISTURE REGIME (MEAN): SUBHYGRIC

NUTRIENT REgIME (MEAN): RICH

ELEVATION: $576 \mathrm{M}$

SOIL DRAINAGE (MEAN): IMPERFECTLY

ECOLOGICAL STATUS SCORE: $16-8$ or $12-6$

HEALTH FORM: RIPARIAN

Forage Production(KG/Ha) $n=4$

GRASS 2121(1566-2478)

FORB 547(492-1204)

TOTAL 2138(2770-2970)

ECOLOGICALLY SUSTAINABLE STOCKING RATE $1.01 \mathrm{ha} / \mathrm{AUM}(2.02-0.51)$ $0.4 \mathrm{AUM} / \mathrm{ac}(0.2-0.8)$ 


\section{CMA9. Willow/Marsh reed grass}

(Salix spp./Calamagrostis canadensis, C. inexpansa)

$\mathbf{n = 1 0}$ The Marsh reed grass community type is found along the edges of sedge meadows and in moist depressions.

Willow will invade onto these sites to form the Willow/Marsh reed grass community type. Increased grazing pressure on these sites will cause marsh reed grass to decline and there will be an invasion of Kentucky bluegrass and dandelion. These sites are highly productive for domestic livestock and should be rated as primary range. Increased flooding and prolonged waterlogging may result in the disappearance of willow and a transition to a water sedge meadow.

These sites are fairly productive but difficult to graze due to the moist ground conditions and heavy shrub cover which reduces access and mobility within the area.

\section{Plant Composition Canopy Cover(\%) MEAN RANGE CONST.}

\section{SHrubS}

WILLOW SPP.

(Salix spp.)

$48 \quad 0-80 \quad 80$

FLAT LEAVED WILLOW

(Salix planifolia)

BEBB WILLOW

(Salix bebbiana)

$11 \quad 0-60 \quad 20$

$2 \quad 0-20 \quad 10$

\section{FORBS}

MINT

$\begin{array}{llll}\text { (Mentha arvensis) } & 1 & 0-7 & 40 \\ \text { DANDELION } & & & \end{array}$

$\begin{array}{llll}\text { (Taraxacum officinale) } & 2 & 0-13 & 60\end{array}$

\section{GraSSES}

KENTUCKY BLUEGRASS

(Poa pratensis)

$2 \quad 0-7 \quad 40$

MARSH REED GRASS

(Calamagrostis canadensis) 26

BEAKED SEDGE

(Carex rostrata)

WATER SEDGE

(Carex aquatilis)

NORTHERN REED GRASS

(Calamagrostis inexpansa) 5

\section{ENVIRONMENTAL VARIABLES}

MoISTURE REGIME (MEAN):

SUBHYGRIC

NUTRIENT REGIME (MEAN): $\mathrm{RICH}$

ELEVATION:

333-853 (577) M

SoIL Drainage (MEAN): POORLY

ECOLOGICAL STATUS SCORE: 24 or 18

HEALTH FORM: RIPARIAN

Forage Production(Kg/Ha) $n=8$

$\begin{array}{ll}\text { GRASS } & 951(318-2010) \\ \text { FORB } & 219(0-270) \\ \text { SHRUB } & 336(0-554) \\ \text { TOTAL } & 1353(588-2118)\end{array}$

ECOLOGICALLY SUSTAINABLE STOCKING RATE $0.81 \mathrm{ha} / \mathrm{AUM}(2.02-0.40)$ $0.5 \mathrm{AUM} / \mathrm{ac}(0.2-1.0)$ 


\section{CMA10. Willow-River alder/Marsh reed grass \\ (Salix spp-Alnus tenuifolia/Calamagrostis canadensis)}

$\mathbf{n = 6}$ This community type represents a tall willow and alder dominated type that is usually represented as an AIA aspen stand on phase III maps. It is typically found in very moist, poorly drained areas. Black spruce communities are usually found associated with this community type on the wetter edges. The understory of this community type is fairly open allowing for easy access by livestock. When this community is situated next to trails or seismic lines it is moderately utilized by livestock.

\section{Plant Composition Canopy Cover(\%) MEAN RANGE CONST.}

\section{SHRUBS}

FLAT LEAVED WILLOW

(Salix planifolia)

WILLOW SPP.

(Salix spp.)

RIVER ALDER

(Alnus tenuifolia)

GREEN ALDER

(Alnus crispa)

WILD RED RASPBERRY

(Rubus idaeus)

BRACTED HONEYSUCKLE

(Lonicera involucrata)

\section{FORBS}

STRAWBERRY

(Fragaria virginiana) 1

SWEET SCENTED BEDSTRAW

(Galium triflorum)

3

6

32

20

9

11

4

WILD SARSAPARILLA

(Aralia nudicaulis)

DEWBERRY

(Rubus pubscens)

4

4

3

\section{Grasses}

MARSH REED GRASS

(Calamagrostis canadensis) 40

BEAKED SEDGE

(Carex rostrata)
$14-60 \quad 100$

0-27 $\quad 17$

\section{ENVIRONMENTAL VARIABLES}

MoISTURE REgIME (MEAN): SUBHYGRIC-HYGRIC

NUTRIENT REgIME (MEAN): $\mathrm{RICH}$

Elevation: $576 \mathrm{M}$

SoIl DRAINAGE (MEAN): IMPERFECTLY

ECOLOGICAL STATUS SCORE: 24

HEALTH FORM: RIPARIAN

\section{Forage Production(Kg/Ha) $n=4$}

$\begin{array}{ll}\text { GRASS } & 702(118-1102) \\ \text { FORB } & 184(18-470) \\ \text { SHRUB } & 61(0-132) \\ \text { TOTAL } & 947(592-1296)\end{array}$

ECOLOGICALLY SUSTAINABLE STOCKING RATE $2.02 \mathrm{ha} / \mathrm{AUM}(2.02-1.01)$ $0.2 \mathrm{AUM} / \mathrm{ac}(0.2-0.4)$ 


\section{CMA11. Willow/Fireweed (Salix spp./Epilobium angustifolium)}

$\mathbf{n = 1}$ This community type represents a 3 year old burn of a white spruce forest. Fireweed and marsh reed grass early successional species quickly dominate the community after a fire. As this community undergoes succession the herbaceous understory will be suppressed as a result of shading by white spruce. Eliminating the tree canopy cover has increased the forage production of this site from $50-100 \mathrm{~kg} / \mathrm{ha}$ under a spruce moss forest to over 1700 $\mathrm{kg} / \mathrm{ha}$ on this community type.

\section{Plant Composition Canopy Cover(\%)}

MEAN RANGE CONST.

TREES

ASPEN

$\begin{array}{llll}\text { (Populus tremuloides) } & 1 & - & 100\end{array}$

WHITE SPRUCE

$\begin{array}{llll}\text { (Picea glauca }) & 10 & - & 100\end{array}$

SHRUBS

WILLOW SPP.

(Salix spp.)

$21 \quad-\quad 100$

ForBs

STRAWBERRY

$\begin{array}{llll}\text { (Fragaria virginiana) } & 2 & - & 100\end{array}$

FIREWEED

(Epilobium angustifolium) $37 \quad-\quad 100$

YARROW

(Achillea millefolium) 2

LARGE LEAVED YELLOW AVENS

(Geum macrophyllum) $\quad 2 \quad$ - $\quad 100$

Grasses

MARSH REED GRASS

(Calamagrostis canadensis) $19 \quad-\quad 100$

HAIR-LIKE SEDGE

(Carex capillaris)

\section{ENVIRONMENTAL VARIABLES}

MOISTURE REGIME (MEAN): SUBHYGRIC-MESIC

NUtRiENT REgime (MEAN): MEDIUM

ELEVATION:

$150 \mathrm{M}$

SoIL DRAINAGE (MEAN): MODERATELY WELL

ECOLOGICAL STATUS SCORE: 18

Forage Production(Kg/Ha) n=1

$\begin{array}{ll}\text { GRASS } & 190 \\ \text { FORB } & 1322 \\ \text { SHRUB } & 236 \\ \text { TOTAL } & 1748\end{array}$

ECOLOGICALLY SUSTAINABLE STOCKING RATE $4.05 \mathrm{ha} / \mathrm{AUM}(40.47-1.01)$

$0.1 \mathrm{AUM} / \mathrm{ac}(0.01-0.4)$ 


\section{CMA12. Willow-Spruce/Kentucky bluegrass \\ (Salix spp.-Picea glauca/Poa pratensis)}

$\mathbf{n = 1}$ This community represents an old spruce community which burned in 1968, succeeded to willow, and is now succeeding back to white spruce. After the fire, the canopy was opened up allowing for good forage productivity. Consequently, cattle grazing was quite heavy allowing Kentucky bluegrass and clover to establish. Thistle is now beginning to invade and will expand to other areas if not controlled. As the spruce continues to mature, the increasing canopy cover will cause a decline in overall production and this site will eventually become non-use for domestic livestock.

\section{Plant Composition Canopy Cover(\%) \\ MEAN RANGE CONST.}

\section{Trees}

\section{LARCH}

(Larix laricina)

8

WHITE SPRUCE(UNDERSTORY)

(Picea glauca)

$3 \quad-\quad 100$

SHRUBS

WILLOW SPP.

(Salix spp.)

50

FORBS

Clover

(Trifolium sp.)

DANDELION

(Taraxacum officinale)

MARSH HEDGE NETTLE

(Stachys palustris)

BISHOP's CAP

(Mitella nuda)

CANADA THISTLE

(Cirsium arvense)

GRASSES

KENTUCKY BLUEGRASS

(Poa pratensis)

\section{ENVIRONMENTAL VARIABLES}

MOISTURE REGIME (MEAN):

\section{SUBHYGRIC}

NUTRIENT REGIME (MEAN): RICH

ELEVATION: $667 \mathrm{M}$

SoIl Drainage (MEAN): MODERATELY WELL TO IMPERFECTLY

ECOLOGICAL STATUS SCORE: 0 or MODIFIED

\section{Forage Production(Kg/Ha) $n=1$}

$\begin{array}{ll}\text { GRASS } & 1985 \\ \text { FORB } & 540 \\ \text { SHRUB } & 0 \\ \text { TOTAL } & 2524\end{array}$

ECOLOGICALLY SUSTAINABLE STOCKING RATE 40.47 ha/AUM (40.47 - 4.05) $0.01 \mathrm{AUM} / \mathrm{ac}(0.01-0.1)$ 


\section{CMA13. Yellow willow \\ (Salix lutea)}

$\mathbf{n = 1}$ This community type occurs on moist alluvial deposits which are adjacent to streams and rivers. This community can persist for some time if the site is subject to frequent flooding. However in the absence of disturbance it will eventually undergo succession to a spruce dominated community type. Thompson and Hansen (2002) described this community in the grassland natural region of Southern Alberta. They found that this community type disappeared as one moved north into the Parkland and it was replaced by basket willow and flat leaved willow dominated community types. Typically there is little understory vegetation found in this community type and it should be rated as non-use for livestock.

\section{PLANT COMPOSITION CANOPY COVER (\%) MEAN Range Const.}

\section{SHRUBS}

YELLOW WILLOW

(Salix lutea)

SHINING WILLOW

(Salix lucida)

RIVER ALDER

(Alnus tenuifolia)

$\begin{array}{lll}30 & - & 100 \\ 10 & - & 100 \\ 3 & - & 100\end{array}$

\section{FORBS}

HORSETAIL

(Equisetum arvense)

VEINY MEADOW RUE

(Thalictrum venulosum)

DANDELION

(Taraxaxum officinale)

1

100

100

100

\section{GRAMINOIDS}

MARSH REED GRASS

(Calamagrostis canadensis) 10

KENTUCKY BLUEGRASS

(Poa pratensis)

QUACKGRASS

(Agropyron repens)

\section{ENVIRONMENTAL VARIABLES}

Moisture Regime: Hygric

NUTRIENT REGIME: RICH

ELEVATION:

$600 \mathrm{M}$

SOIL DRAINAGE: IMPERFECTLY

ECOLOGICAL STATUS SCORE: 24 or 18

HEALTH FORM: RIPARIAN

Forage Production (KG/Ha)

TOTAL $1000 *$ ESTIMATE

ECOLOGICALLY SUSTAINABLE STOCKING RATE GENERALLY NON-USE $40.47 \mathrm{ha} / \mathrm{AUM}(40.47-40.47)$ $0.01 \mathrm{AUM} / \mathrm{ac}(0.01-0.01)$ 


\section{CMA14. Scouler willow-Red osier dogwood (Salix scouleriana-Cornus stolonifera)}

$\mathbf{n = 1}$ This community type appears to be transitional between the horsetail (hygric/rich) and shrubby rich fen (subhydric/rich) ecosites described by Beckingham and Archibald (1996). It has plant species characteristic of both ecosites. This community type is also similar to the Willow-Alder/Fern community described on moist, nutrient rich seepage areas in the Lower Foothills subregion (Lane et al. 2000). This community type is very productive, but the high shrub cover and slope conditions make it difficult to graze. Consequently, this community type should be rated as secondary or non-use range.

\section{Plant Composition Canopy Cover(\%)} MEAN RANGE CONST.

\section{SHRUBS}

SCOULER's WILLOW

BRACTED HONEYSUCKLE

(Lonicera involcrata)

RED OSIER DOGWOOD

(Cornus stolonifera)

LOW BUSH CRANBERRY

(Viburnum edule)

\section{FORBS}

BUNCHBERRY

(Cornus canadensis)

COMMON HORSETAIL

(Equisetum arvensis)

FIREWEED

(Epilobium angustifolium) 3

DEWBERRY

(Rubus pubescens)

STRAWBERRY

(Fragaria virginiana)

Grasses

MARSH REED GRASS

(Calamagrostis canadensis) 10

\section{ENVIRONMENTAL VARIABLES}

MoISTURE REgIME (MEAN): SUBHYGRIC

NUTRIENT REGIME (MEAN): RICH

Elevation: $667 \mathrm{M}$

Soll DRAINAGE (MEAN): MODERATELY WELL

ECOLOGICAL STATUS SCORE: 24 or 18

HEALTH FORM: RIPARIAN

Forage Production(Kg/ha)

TOTAL $1500 *$ ESTIMATE

ECOLOGICALLY SUSTAINABLE STOCKING RATE GENERALLY NON-USE 40.47 ha/AUM (40.47 - 2.02) $0.01 \mathrm{AUM} / \mathrm{ac}(0.01-0.2)$ 


\section{CMA15: Bebb willow/Marsh reed grass (Salix bebbiana/Calamagrostis canadensis)}

$\mathbf{n}=3$ This community type is found along the drier edges of marsh reed grass meadows and in moist depressions and represents the transition between the flat leaved willow and basket willow dominated shrublands and the upland forest. Bebb willow is an upland species that prefers well drained sites. This species of willow is often found in the understory of aspen and balsam poplar dominated community types. Increased flooding and prolonged water logging may result in the disappearance of Bebb willow and favour the growth of flat leaved willow. In contrast the continued drying of the site will favour the growth of balsam poplar. These sites are fairly productive but difficul to graze due to the moist ground conditions and heavy shrub cover which reduces access and mobility within the area.

\section{Plant Composition Canopy Cover(\%) MEAN RANGE CONST.}

\section{Trees}

BALSAM POPLAR

(Populus balsamifera)

1

0-1

33

\section{SHRUBS}

BEBB WILLOW

(Salix bebbiana)

$57 \quad 50-70 \quad 100$

FLAT LEAVED WILlow

(Salix planifolia)

RED OSIER DOGWOOD

(Cornus stolonifera)

BRACTED HONEYSUCKLE

(Lonicera involucrata)

\section{FORBS}

Horset AIL

(Equisetum arvense)

TALL LUNGWORT

(Mertensia paniculata)

$1 \quad 0-3 \quad 33$

$1 \quad 0-3 \quad 66$

(Circaea alpina)

SMALL BEDSTRAW

(Galium trifidum)

1

$0-3 \quad 66$

\section{GRASSES}

MARSH REED GRASS

(Calamagrostis

canadensis)

24

$3-40$

100

\section{ENVIRONMENTAL VARIABLES}

Moisture Regime: SubHygriC-Hygric

NUTRIENT REGIME: RICH

ELEVATION (MEAN): $600 \mathrm{M}$

SoIl Drainage: Mod. Well

ECOLOGICAL STATUS SCORE: 24 or 18

HEALTH FORM: RIPARIAN

Forage Production (Kg/Ha)

TOTAL $1500 *$ ESTIMATE

ECOLOGICALLY SUSTAINABLE STOCKING RATE

0.81 ha/AUM $(2.02-0.40)$

$0.5 \mathrm{AUM} / \mathrm{ac}(0.2-1.0)$ 


\section{CMA16. Swamp horsetail (Equisetum fluviatile)}

$\mathbf{n = 1} \quad$ This wetland community type is found near fresh water and is often associated with shallow water around lake shores or saturated wet spots in old river channels and sloughs. This community is often only found in small isolated spots or in narrow bands around the edge of lakes. As these areas dry, swamp horsetail is often replaced by sedge species. Swamp horsetail is generally unpalatable to livestock and the areas it grows in are often to wet for livestock to access. This community type should be rated as non-use.

\section{Plant Composition Canopy Cover(\%)}

\section{FORBS}

SWAMP HORSETAIL

(Equisetum fluviatile)

Grasses

BEAKED SEDGE

(Carex rostrata)

TALL MANNA GRASS

(Glyceria grandis)

SLOUGH GRASS

(Beckmannia syzigachne) 1
97

100

MEAN RANGE CONST.

$7 \quad-\quad 100$

$\begin{array}{ll}- & 100 \\ - & 100 \\ - & 100\end{array}$

\section{ENVIRONMENTAL VARIABLES}

MoISTURE REGIME (MEAN):

SUBHYDRIC-HYGRIC

NUTRIENT REGIME (MEAN):

RICH

ELEVATION:

$600 \mathrm{M}$

Soll Drainage (MEAN): POORLY TO VERY POORLY

ECOLOGICAL STATUS SCORE: 24

HEALTH FORM: RIPARIAN

\section{Forage Production (Kg/Ha)}

TOTAL $2000 *$ ESTIMATE

ECOLOGICALLY SUSTAINABLE STOCKING RATE

GENERALLY NON-USE $40.47 \mathrm{ha} / \mathrm{AUM}(40.47$ - 40.47)

$0.01 \mathrm{AUM} / \mathrm{ac}(0.01-0.01)$ 


\section{CMA17. Tall manna grass \\ (Glyceria grandis)}

$\mathbf{n = 1}$ This wetland community type is associated with the edge of the standing water of ponds, sloughs and slow meandering streams. As one moves away from the water to the drier edges the sedge meadow communities are found. This community is often only found in small isolated spots or in narrow bands around the edge of lakes. As these areas dry, tall manna grass is often replaced by sedge species. Tall manna grass is palatable to livestock, however, the areas it grows in are often to wet for livestock to access. This community type should be rated as non-use.

\section{Plant Composition Canopy Cover(\%)}

MEAN RANGE CONST.

FORBS

MINT

(Mentha arvensis)

20

100

PALE PERSICARIA

(Polygonum lapthifolium) 3

CANADA THISTLE

(Cirsium arvense)

1

100

\section{Grasses}

TALL MANNA GRASS

(Glyceria grandis)

SLOUGH GRASS

(Beckmannia syzigachne) 30

BEBB'S SEDGE

(Carex bebbii)

CREEPING SPIKE RUSH

(Eleocharis palustris)

$\begin{array}{lll}60 & - & 100 \\ 30 & - & 100 \\ 10 & - & 100 \\ 10 & - & 100\end{array}$

ECOLOGICALLY SUSTAINABLE STOCKING RATE

GENERALLY NON-USE

$0.54 \mathrm{ha} / \mathrm{AUM}(2.02-0.31)$

$0.75 \mathrm{AUM} / \mathrm{ac}(0.2-1.3)$

HEALTH FORM: RIPARIAN

Forage Production (KG/Ha)

Grass $\quad 2000$

TOTAL 2000*ESTIMATE

\section{ENVIRONMENTAL VARIABLES}

MOISTURE REGIME (MEAN): SUBHYDRIC-HYGRIC

NUTRIENT REGIME (MEAN): RICH

\section{ELEVATION:} $606 \mathrm{M}$

SOIL DRAINAGE (MEAN): VERY POORLY

ECOLOGICAL STATUS SCORE: 24 or 18

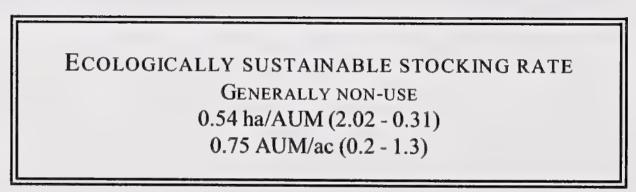




\section{CMA18. Short sedge \\ (Carex curta)}

$\mathbf{n = 1}$ This community type was described in boggy areas adjacent to black spruce and larch dominated community types. Short sedge tends to be found in the wetter areas where there is a floating mat of peat. As these areas dry out short sedge will be replaced by willow, black spruce and larch species. Short sedge is generally unpalatable to livestock and the areas it grows in are often too wet for livestock to access. This community type should be rated as non-use.

\section{Plant Composition Canopy Cover(\%)}

\section{SHRUBS}

MEAN RANGE CONST.

Flat LeAved Willow

$\begin{array}{llll}\text { (Salix planifolia) } & 1 & - & 100\end{array}$

FORBS

WATER HEMLOCK

(Cicuta maculata)

SKULL CAP

(Scutellaria galericulata)

\section{Grasses}

SHORT SEDGE

(Carex curta)

WATER SEDGE

(Carex aquatilis)

NORTHERN REED GRASS

(Calamagrostis inexpansa) 10

100

\section{ENVIRONMENTAL VARIABLES}

MoISTURE REgIME (MEAN):

SUBHYDRIC

NUTRIENT REGIME (MEAN):

MEDIUM

ELEVATION:

576-606(584) M

SOIL DRAINAGE (MEAN):

WELL

ECOLOGICAL STATUS SCORE: 24

HEALTH FORM: RIPARIAN

Forage Production (Kg/HA)
TOTAL $1500 *$ ESTIMATE

ECOLOGICALLY SUSTAINABLE STOCKING RATE

GENERALLY NON-USE

40.47 ha/AUM (40.47 - 40.47)

$0.01 \mathrm{AUM} / \mathrm{ac}(0.01-0.01)$ 


\section{CMA19. Snowberry/Horsetail/Marsh Reed Grass (Symphoricarpos occidentalis/Equisetum arvense/Calamagrostis canadensis)}

$\mathbf{n = 1}$ This snowberry dominated community type appears to be common on level, well drained, gravelly areas along rivers throughout Northern Alberta. In the absence of disturbance this community type is dominated by snowberry, rose, horsetail, fireweed, slender wheatgrass and marsh reedgrass. Heavy grazing pressure causes the native forbs and grasses to decline and allows Kentucky bluegrass, dandelion and clover to increase. Because these clearings are some of the only natural openings throughout the Central Mixedwood they tend to be heavily utilized by livestock. Snowberry which is unpalatable to livestock will remain even under extreme grazing pressure.

\section{Plant Composition Canopy Cover(\%)}

MEAN RANGE CONST.

\section{SHRUBS}

SNOWBERRY

(Symphoricarpos

occidentalis)

BEAKED WILLOW

(Salix bebbiana)

PRICKLY Rose

(Rosa acicularis)

WILD RED RASPBERRY

(Rubus idaeus)

FORBS

COMMON HORSETAIL

(Equisetum arvense)

FIREWEED

(Epilobium angustifolium)

AMERICAN VETCH

(Vicia americana)

LINDLEY's ASTER

(Aster ciliolatus)

COW PARSNIP

(Heracleum lanatum)

STRAWBERRY

(Fragaria virginiana)

Grasses

MARSH REED GRASS

(Calamagrostis

canadensis)

Awned SEDGE

(Carex atherodes)

SLENDER WHEATGRASS

(Agropyron trachycaulum) 3

\section{ENVIRONMENTAL VARIABLES}

Moisture Regime (MEAN): SUBHYGRIC - HYGRIC

NUTRIENT REgime (MEAN): RICH

ELEVATION: $758 \mathrm{M}$

SoIL DrainAge (MEAN): WELL

ECOLOGICAL STATUS SCORE: 24

HEALTH FORM: RIPARIAN

Forage Production (KG/HA)

TOTAL $2250 *$ EsTIMATE

ECOLOGICALLY SUSTAINABLE STOCKING RATE $0.5 \mathrm{ha} / \mathrm{AUM}(2.02-0.4)$ 0.81 AUM/ac (0.2 - 1.01) 


\title{
CENTRAL MIXEDWOOD SUBREGION
}

\author{
TAME FORAGE COMMUNITIES
}

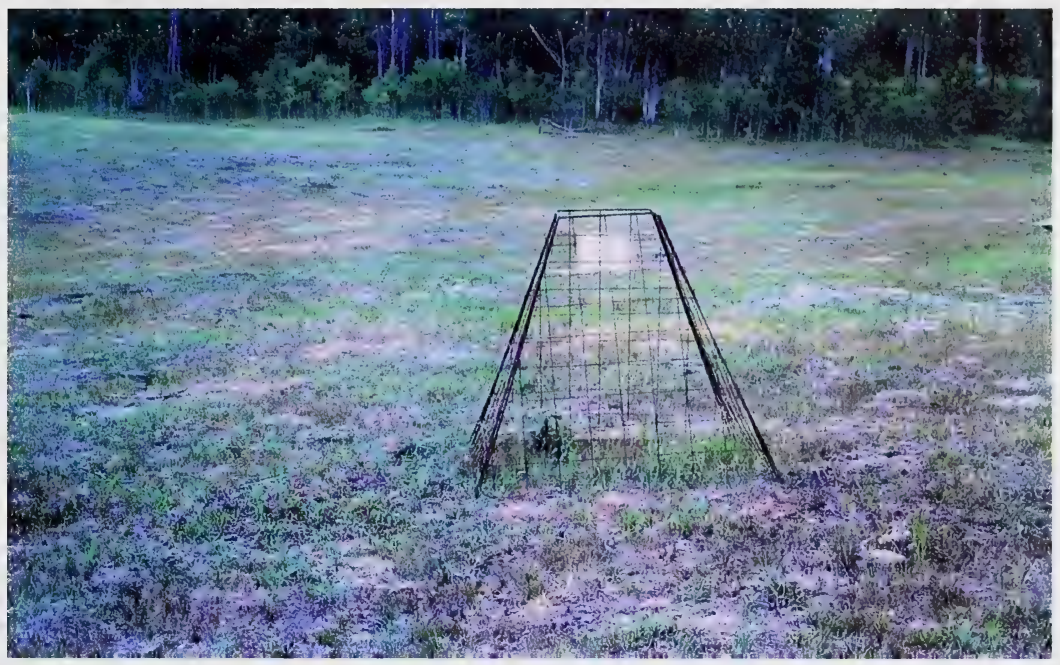

Photo 8. This range improvement clearing exhibits signs of heavy grazing pressure and is slowly being invaded by tall buttercup. 


\section{TAME FORAGE COMMUNITIES}

\section{(Cleared areas that have been broken and seeded to tame forage)}

Throughout the Central Mixedwood subregion there are sites that have been deforested, broken, and seeded to tame forage. Usually these areas are mesic and moderately well to well drained with good nutrient levels. Because most of these tame forage stands are established on similar sites, the most influential factors affecting plant species composition are stand establishment and grazing regime.

Stand establishment is important because it determines what the initial plant species composition is going to be. Seed bed preparation and the type of seed sown are the two most important factors influencing stand establishment. Seed bed preparation is important because it helps to determine how well the sown seed germinates and establishes. If the seed bed is not well prepared, the tame forage species may have reduced seedling vigour and/or density allowing native or weedy species to become a dominant component of the plant community.

After the stand is established, the grazing regime applied to the stand will influence the plant species composition. Generally, a light to moderate level of grazing allows the stand to maintain itself while sustained heavy grazing causes the stand to degrade. Damage to a stand due to overgrazing occurs more readily while the stand is establishing than it does when the stand is established. This is because the forage plants in an establishing stand have not had time to develop energy reserves or substantial root systems and are therefore more susceptible to grazing induced stress.

Figure 9 is a successional diagram for tame pastures in the Central Mixedwood subregion. Tame pasture communities are organized horizontally by moisture gradient [e.g. dry (submesic) to moist (subhygric)] and vertically by successional factors like the grazing disturbance gradient [e.g. moderate or very heavily grazed] or stand establishment. A light to moderate grazing regime will normally maintain a forage stand similar to what was seeded on the site. These stands are generally the most productive and provide the best grazing opportunities for livestock. In figure 9 , these plant communities are indicated by the bolded boxes and represent various seed mixes sown on submesic to subhygric sites (not just those species in the plant community name) They are considered to be in the healthy category for range health.

The plant communities represented by the boxes above the bolded boxes may be the result of a number of different factors. For example, when the site is under-grazed, the stand becomes dominated by species that are the most competitive in the absence of grazing disturbance. In this case, trees and shrubs growth is unchecked and they can out-compete seeded plants for light and other resources. Poor forage establishment is another factor that can result in stands that are dominated by native or weedy species. Although shrubs and trees can occur on all tame pasture community types, the extent to which invasion occurs is influenced by site preparation, forage establishment, moisture conditions, age of stand and grazing history.

Plant community changes which occur under heavy grazing are dependent on the grazing history (level of use, season of use and duration of the grazing regime). Overgrazed community types [plant communities at bottom of Figure 9] develop over a long period of repeated overgrazing. If weedy species such as tall buttercup or Canada thistle, become established on overgrazed sites, they can quickly become a dominant species. 
Figure 9. Successional sequences of tame pasture communities on 3 moisture regimes in the Central Mixedwood subregion.

\begin{tabular}{|c|c|c|c|c|}
\hline & $\begin{array}{l}\text { SUBMESIC } \\
\text { SITES }\end{array}$ & MESIC SITES & $\begin{array}{c}\text { SUBHYGRIC } \\
\text { SITES }\end{array}$ & \\
\hline $\begin{array}{l}\text { SUCCESSIONAL } \\
\text { CHANGES } \\
\text { tree species become } \\
\text { dominant }\end{array}$ & & & & $\begin{array}{c}\text { SUCCESSION } \\
\text { FACTORS }\end{array}$ \\
\hline $\begin{array}{l}\text { some woody } \\
\text { regrowth and native } \\
\text { herbaceous species }\end{array}$ & $\begin{array}{l}\text { Creeping Red } \\
\text { Fescue (CRF)- } \\
\text { Hairgrass } \\
\text { CMB5 } \\
\end{array}$ & $\begin{array}{c}\text { Marsh Reedgrass/ } \\
\text { Strawberry } \\
\text { CMB13 }\end{array}$ & & \\
\hline $\begin{array}{l}\text { reversion to native } \\
\text { plants }\end{array}$ & & & & $\begin{array}{l}\text { poor stand } \\
\text { establishment or } \\
\text { under-grazing }\end{array}$ \\
\hline $\begin{array}{l}\text { dominated by the } \\
\text { tall, productive } \\
\text { species originally } \\
\text { seeded [i.e. desirable } \\
\text { species] }\end{array}$ & & $\begin{array}{c}\text { Brome / Timothy } \\
\text { CMB8 }\end{array}$ & & $\begin{array}{l}\text { light to } \\
\text { moderately } \\
\text { grazed }\end{array}$ \\
\hline & & & & $\begin{array}{l}\text { moderately to } \\
\text { heavily grazed }\end{array}$ \\
\hline $\begin{array}{l}\text { decline in desirable } \\
\text { species with some } \\
\text { grazing induced } \\
\text { species present }\end{array}$ & & $\begin{array}{c}\text { CRF-Kentucky } \\
\text { Bluegrass-Timothy } \\
\text { CMB9 }\end{array}$ & & \\
\hline $\begin{array}{l}\text { dominated by } \\
\text { grazing induced } \\
\text { species with some } \\
\text { weedy species }\end{array}$ & & $\begin{array}{c}\text { CRF- Kentucky } \\
\text { Bluegrass/ } \\
\text { Dandelion } \\
\text { CMB10 } \\
\end{array}$ & $\begin{array}{c}\text { Willow-CRF- } \\
\text { Kentucky Bluegrass } \\
\text { CMB12 }\end{array}$ & heavily grazed \\
\hline $\begin{array}{l}\text { dominated by } \\
\text { grazing induced } \\
\text { and/or weedy } \\
\text { species }\end{array}$ & & $\begin{array}{l}\text { Clover/Dandelion } \\
\text { CMB11 }\end{array}$ & & $\begin{array}{l}\text { very heavily } \\
\text { grazed }\end{array}$ \\
\hline
\end{tabular}




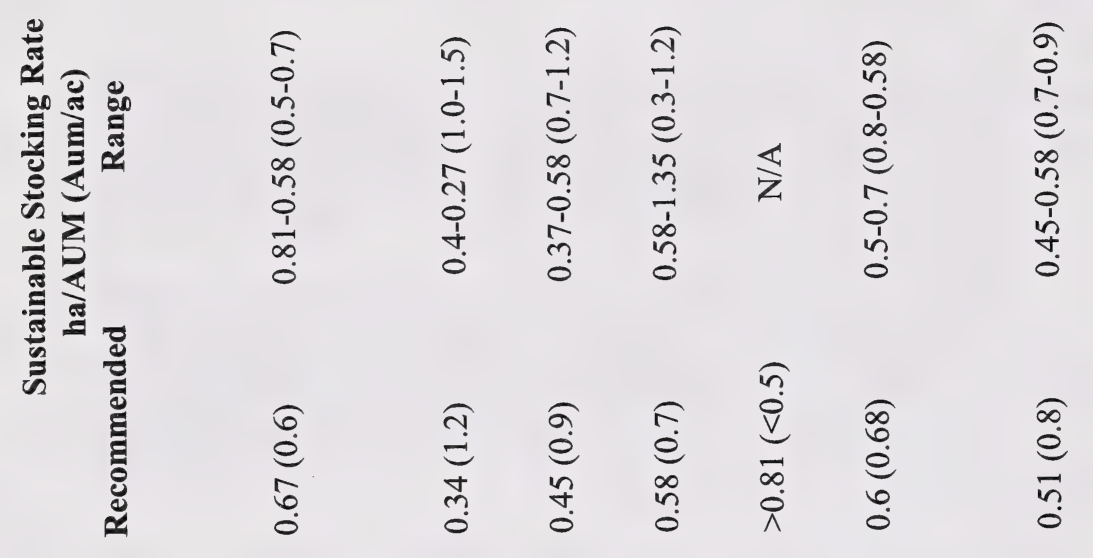

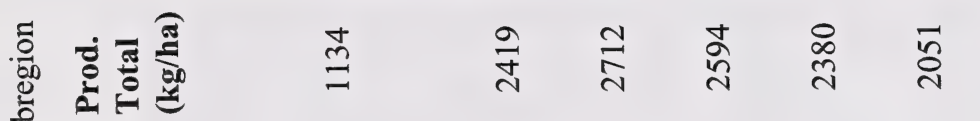

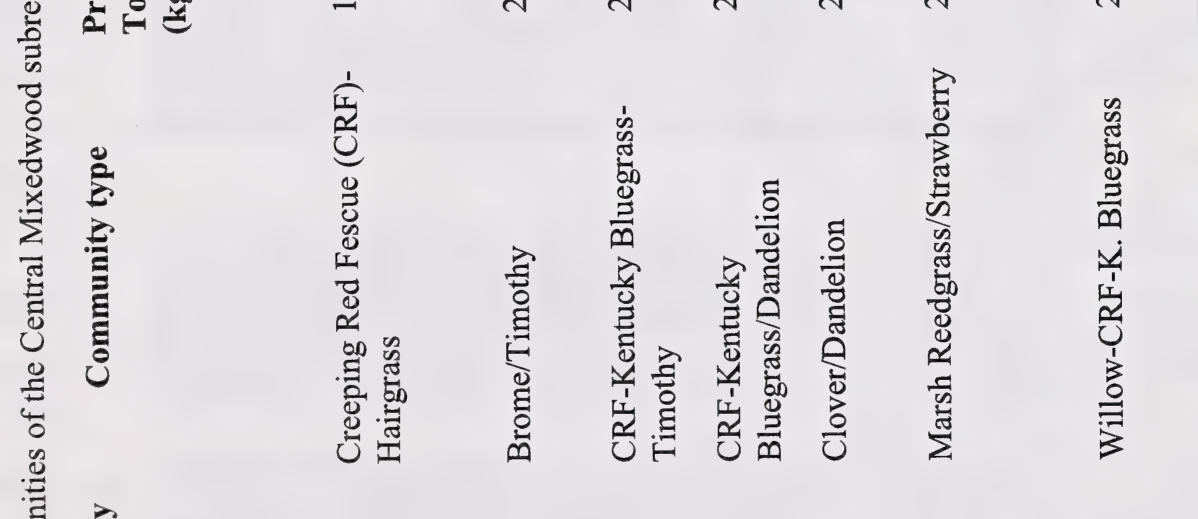

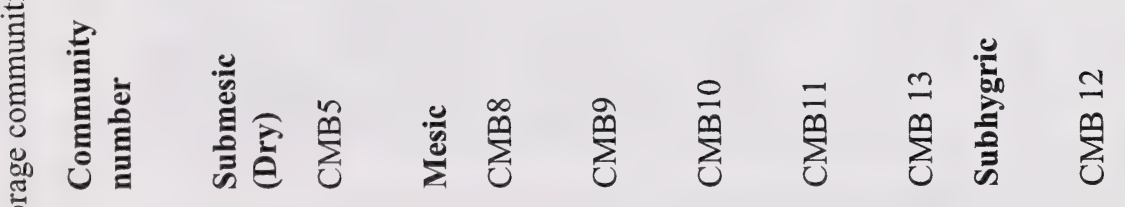

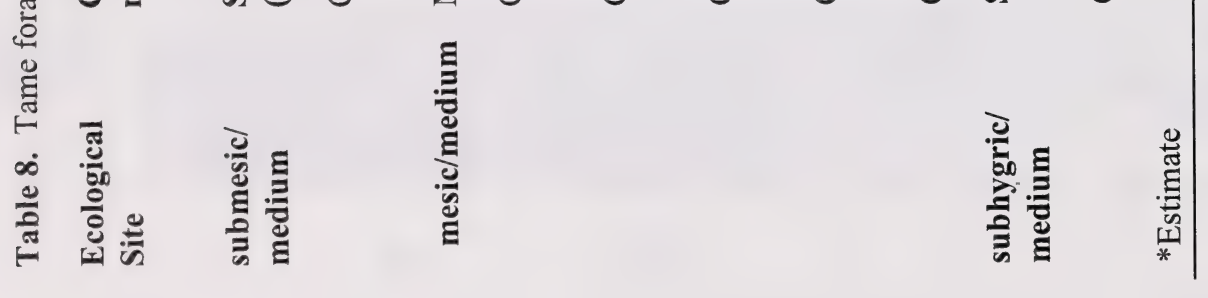




\section{Key to Tame Grass Plant Communities - Central Mixedwood Subregion}

1. Tame forage stand dominated by tall productive species or sites invaded by native plants like marsh reedgrass...............................................................................................

Tame forage stand modified by grazing or poorly established......................................

2. Mesic sites dominated by brome, wheat grass, timothy or other tall productive species Brome/Timothy (CMB8) Invaded tame pasture dominated by marsh reedgrass and strawberry

.Marsh Reedgrass/Strawberry(CMB13)

3. Heavily grazed mesic to subhygric sites. 4

Submesic sites with poor establishment of seed mix, extensive bare ground and many weedy species Creeping Red Fescue-Hairgrass (CMB5)

4. Heavily grazed creeping red fescue and/or Kentucky bluegrass dominates. .5 Very heavily grazed, weedy invaders common, low-growing species (e.g. clover) dominate .Clover/Dandelion (CMB11)

5. Some tall productive species (brome, timothy) still present in the stand. Creeping Red Fescue-Kentucky Bluegrass-Timothy (CMB9) Site dominated by grazing resistant species

6. Mesic site (submesic to subhygric)

..Creeping Red Fescue-Kentucky Bluegrass-Dandelion (CMB10) Subhygric site, willow present.

.Willow-Creeping Red Fescue-Kentucky Bluegrass (CMB12) 


\section{CMB5. Creeping red fescue-Rough hairgrass}

(Festuca rubra-Agrostis scabra)

$\mathbf{n = 1}$ This community type represents an area that was cleared and seeded, however due to poor soil conditions, it established poorly. The soils on this site are sandy to a depth of about 6 inches and hairgrass is well adapted to growing on these disturbed sites with poor nutrients. The overall cover of vegetation is sparse, therefore grazing should only be light in order to maintain the little cover of vegetation. This site should not have been approved for range improvement.

\section{Plant Composition Canopy Cover(\%)}

MEAN RANGE CONST

FORBS

THREE TOOTHED CINQUEFOIL

(Potentilla tridentata) 3

ROUGH CINQUEFOIL

$\begin{array}{llll}\text { (Potentilla norvegica) } & 1 & - & 100\end{array}$

\section{GraSSES}

ROUGH HAIRGRASS

(Agrostis scabra)

Тімотну

(Phleum pratense)

CREEPING RED FESCUE

(Festuca rubra)

$\begin{array}{lll} & & \\ 6 & - & 100 \\ 2 & - & 100 \\ 12 & - & 100\end{array}$

\section{ENVIRONMENTAL VARIABLES}

MOISTURE REGIME (MEAN):

SUBMESIC

NUTRIENT REGIME (MEAN): POOR

ELEVATION:

$579 \mathrm{M}$

SoIl DRAINAGe (MEAN):

WELL

Plant COMPOSITION:

TAME

DESIRABLE SPECIES SHIFT SCORE: 0

\section{FORAGE PRODUCTION(KG/HA) $\mathrm{n}=1$}

$\begin{array}{lr}\text { GraSS } & 832 \\ \text { ForbS } & 302 \\ \text { SHRUBS } & 0 \\ \text { TOTAL } & 11\end{array}$

ECOLOGICALLY SUSTAINABLE STOCKING RATE $0.67 \mathrm{ha} / \mathrm{AUM}(0.81-0.58)$

$0.6 \mathrm{AUM} / \mathrm{ac}(0.5-0.7)$ 


\section{CMB8. Brome/Timothy \\ (Bromus spp. / Phleum pratense)}

n=4 This community type represents healthy condition tame pasture on mesic sites that were seeded with various mixtures of timothy, smooth brome, meadow brome, creeping red fescue, alfalfa, and/or clover. Timothy establishes much quicker than creeping red fescue or smooth brome on pastures that have been recently seeded. Eventually creeping red fescue and smooth brome will outcompete timothy and this community will likely become dominated by creeping red fescue and smooth brome. Heavy grazing pressure will cause the tall growing grass species (brome, timothy) to decline and allows low growing Kentucky bluegrass and dandelion to increase to form communities CMB9 and CMB10. Continued heavy grazing pressure will eventually lead to a community dominated by clover, dandelion and weeds (CMB11).

\section{Plant Composition Canopy Cover(\%)} MEAN RANGE CONST.

\section{FORBS}

\section{Clover}

(Trifolium spp.)

DANDELION

\section{(Taraxacum officinale)}

STRAWBERRY

(Fragaria virginiana)

$\begin{array}{lll}2 & 0-3 & 75 \\ 12 & 0-41 & 50 \\ 4 & 0-11 & 50\end{array}$

\section{Grasses}

SMOOTH BROME

(Bromus inermis)

FRINGED BROME

(Bromus ciliatus)

Тімотну

(Phleum pratense)

KENTUCKY BLUEGRASS

(Poa pratensis)

Creeping Red Fescue

(Festuca rubra)

SEDGES

(Carex spp.)

\section{ENVIRONMENTAL VARIABLES}

MoISTURE REGIME (MEAN):

(MESIC) TO SUBHYGRIC

NUTRIENT REGIME (MEAN):

(MEDIUM) TO RICH

ELEVATION:

$576-853(645) \mathrm{M}$

SoIL DRAINAGE (MEAN):

(WELL) TO MODERATELY WELL

PLANT COMPOSITION:

TAME

DESIRABLE SPECIES SHIFT SCORE: 8

Forage Production(Kg/Ha) $n=4$

GRASS 1660(200-3568)

FORBS 758(4-1876)

SHRUBS 0

TOTAL 2419(670-5444)

ECOLOGICALLY SUSTAINABLE STOCKING RATE

$0.34 \mathrm{ha} / \mathrm{AUM}(0.4-0.27)$

$1.2 \mathrm{AUM} / \mathrm{ac}(1.0-1.5)$ 


\section{CMB9. Creeping Red Fescue-Kentucky Bluegrass-Timothy \\ (Festuca Rubra-Poa pratensis-Phleum pratense)}

$\mathbf{n}=\mathbf{1 0}$ This community type develops on mesic sites that were seeded to a mixture of brome, timothy or other productive species with some grazing resistant species like creeping red fescue. Heavy grazing pressure results in a decline in the proportions of tall, productive species and an increase in the grazing resistant species. Heavy continuous grazing will allow Kentucky bluegrass and dandelion to invade into the stand to form a Kentucky bluegrass or Quackgrass/Dandelion dominated community type. This community type is usually considered to be in the 'healthy with problems' category.

\section{Plant Composition Canopy Cover(\%) \\ MEAN RANGE CONST.}

\section{FORBS}

\section{Clover}

(Trifolium spp.)

DANDELION

(Taraxacum officinale)

STRAWBERRY

(Fragaria virginiana)

YARROW

(Achillea millefolium)

GRASSES

Creeping Red Fescue

(Festuca rubra)

KENTUCKY BLUEGRASS

(Poa pratensis)

TIMOTHY

(Phleum pratense)

SмOоTн BROME

(Bromus inermis) 3

$\begin{array}{lll}20 & 1-67 & 100 \\ 20 & 1-47 & 100 \\ 5 & 0-16 & 73 \\ 1 & 0-4 & 82 \\ 21 & 0-73 & 55 \\ 20 & 0-64 & 82 \\ 14 & 1-25 & 100 \\ 0-17 & 36 & \end{array}$

\section{ENVIRONMENTAL VARIABLES}

MOISTURE REGIME (MEAN): (MESIC) TO SUBHYGRIC

NUTRIENT REGIME (MEAN): (MEDIUM) TO RICH

\section{ELEVATION:}

576-853(624)M

Soll Drainage (MEAN):

(WELL) TO MODERATELY WELL

PLANT COMPOSITION:

TAME

DESIRABLE SPECIES SHIFT SCORE: 4 - 0

\section{Forage Production(Kg/Ha) $\mathrm{n}=10$}

$\begin{array}{ll}\text { GRASS } & 1774(848-5304) \\ \text { FORBS } & 938(68-2042) \\ \text { SHRUB } & 0 \\ \text { TOTAL } & 2712(1214-5372)\end{array}$

ECOLOGICALLY SUSTAINABLE STOCKING RATE $0.45 \mathrm{ha} / \mathrm{AUM}(0.58-0.34)$ $0.9 \mathrm{AUM} / \mathrm{ac}(0.7-1.2)$ 


\section{CMB10. Creeping Red Fescue-Kentucky Bluegrass/Dandelion}

\section{((Festuca Rubra-Poa pratensis-Taraxacum officinale)}

$\mathbf{n = 1 4}$ This community is representative of heavily grazed mesic sites and is dominated by grazing resistant species like Kentucky Bluegrass, Creeping Red Fescue or Quackgrass. Heavy grazing tends to favour the growth of these low-growing or rhizomatuous species and that of weedy or disturbance induced species such as dandelion. These sites have poor health ratings and lower production than community types dominated by species like timothy and brome.

\section{Plant Composition Canopy Cover(\%)}

MEAN RANGE CONST.

\section{FORBS}

\section{Clover}

\section{(Trifolium spp.) \\ DANDELION}

(Taraxacum officinale)

CANADA THISTLE

(Cirsium arvense)

Grasses

KENTUCKy BLUEgRASS

(Poa pratensis)

CREePING Red Fescue

(Festuca rubra)

Sмоотн BRoмe

(Bromus inermis) 1

QUACKGRASS

(Agropyron repens)

Тімотну

(Phleum pratense)

$\begin{array}{lll}9 & 0-35 & 43 \\ 13 & 0-89 & 86 \\ 1 & 0-19 & 14 \\ 40 & 4-81 & 100 \\ 22 & 0-79 & 50 \\ 0-8 & 36 & \\ 7 & 0-55 & 14 \\ 1 & 0-3 & 50\end{array}$

\section{ENVIRONMENTAL VARIABLES}

Moisture Regime (MEAN):

SUBMESIC TO SUBHYGRIC (MESIC)

NUTRIENT REGIME (MEAN):

(MEDIUM) TO RICH

ELEVATION:

333-667 (574)M

SoIl DRAINAGE (MEAN):

RAPIDLY TO MODERATELY WELL (WELL)

PLANT COMPOSITION:

TAME

DESIRABLE SPECIES SHIFT SCORE: 0

\begin{tabular}{ll} 
FORAGE PRODUCTION(KG/HA) & $\mathrm{n}=14$ \\
\hline GRASS & $1883(724-4406)$ \\
FORBS & $746(0-3322)$ \\
SHRUBS & $86(0-162)$ \\
TOTAL & $2594(988-4866)$
\end{tabular}

ECOLOGICALLY SUSTAINABLE STOCKING RATE $0.58 \mathrm{ha} / \mathrm{AUM}(1.35-0.34)$

$0.7 \mathrm{AUM} / \mathrm{ac}(0.3$ - 1.2) 


\section{CMB11. Clover/Dandelion \\ (Trifolium spp./Taraxacum officinale)}

$\mathbf{n}=\mathbf{1}$ This community represents extremely heavily grazed mesic pasture sites. Generally, all that is left growing on these areas is clover and dandelion. There also tends to be a lot of bare soil, which provides a place for noxious weeds (e.g. Canada thistle) to become established. This community would be rated unhealthy.

\section{Plant Composition Canopy Cover(\%)}

MEAN RANGE CONST.

FORBS

Clover

(Trifolium spp.)

$\begin{array}{lll}33 & 33 & 100 \\ 4 & 4 & 100 \\ 5 & 5 & 100 \\ 4 & 100 & \\ 4 & 4 & 100 \\ 11 & 11 & 100 \\ 7 & 7 & 100 \\ 4 & 4 & 100 \\ 1 & 1 & 100\end{array}$

DANDELION

(Taraxacum officinale)

SHEPHERD'S PURSE

(Capsella bursa-pastoris)

ANNUAL HAWKSBEARD

(Crepis tectorum) 4

$\begin{array}{lll}33 & 33 & 100 \\ 4 & 4 & 100 \\ 5 & 5 & 100 \\ 4 & 100 & \\ 4 & 4 & 100 \\ 11 & 11 & 100 \\ 7 & 7 & 100 \\ 4 & 4 & 100 \\ 1 & 1 & 100\end{array}$

Grasses

KENTUCKY BLUEGRASS

(Poa pratensis)

TIмотну

(Phleum pratense)

Fowl Bluegrass

(Poa palustris)

QUACKGRASS

(Agropyron repens)

CREEPING RED FESCUE

(Festuca rubra)

\section{ENVIRONMENTAL VARIABLES}

MoISTURE REgIME (MEAN): MESIC

NUTRIENT REgIME (MEAN): MEDIUM

ELEVATION: $333 \mathrm{M}$

SoIl DRAINAGE (MEAN): MODERATELY WELL

PLANT COMPOSITION: TAME

DESIRABLE SPECIES SHIFT SCORE: 0

\section{Forage Production(Kg/Ha) $n=1$}

$\begin{array}{lr}\text { Grass } & 1154 \\ \text { FORBS } & 1226 \\ \text { SHRUBS } & 0 \\ \text { TOTAL } & 2380\end{array}$

ECOLOGICALLY SUSTAINABLE STOCKING RATE $>0.81 \mathrm{ha} / \mathrm{AUM}$ $<0.5 \mathrm{AUM} / \mathrm{ac}$ 


\section{CMB12. Willow/Creeping red fescue/Kentucky Bluegrass (Salix spp./Festuca rubra/Poa pratensis)}

$\mathbf{n = 2}$ This community represents subhygric pastures that have been heavily grazed and is dominated by grazing resistant species such as creeping red fescue and Kentucky bluegrass. The moisture regime has led to the encroachment of willow species. Burning, cultivation and spraying with herbicide are all options that can be considered in order to control shrub regrowth.

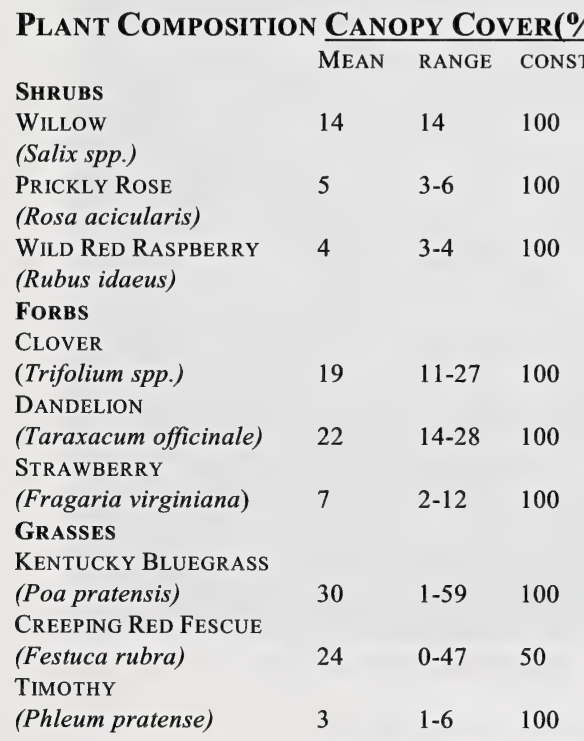

\section{ENVIRONMENTAL VARIABLES}

Moisture Regime (MEAN): MESIC TO (SUBHYGRIC)

NUTRIENT REGIME (MEAN): MEDIUM

ELEVATION: 606-636 (621)M

SoIl DrainAge (MEAN): (MODERATELY WELL) TO WELL

PLANT COMPOSITION: TAME

DESIRABLE SPECIES SHIFT SCORE: 0

Forage Production(KG/Ha) $n=2$

GRASS $927(700-1154)$

FORB $1265(1226-1304)$

SHRUB $50(0-100)$

TOTAL $2242(2104-2380)$

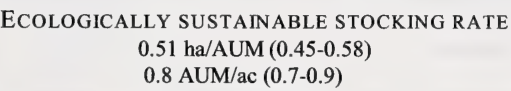

ECOLOGICALLY SUSTAINABLE STOCKING RATE $0.51 \mathrm{ha} / \mathrm{AUM}(0.45-0.58)$ $0.8 \mathrm{AUM} / \mathrm{ac}(0.7-0.9)$ 


\section{CMB13. Marsh Reed Grass/Strawberry \\ (Calamagrostis canadensis/Fragaria virginiana)}

$\mathbf{n}=\mathbf{2}$ This community type appears to be in an early to mid-successional stage. It can occur on clear-cuts that were harvested within the past one or two years, range improvements that had poor seed establishment, range improvement sites that have received low grazing intensities, or on pipelines that were not seeded or had poor seed establishment. This community type appears to be associated with a low grazing intensity and it will likely succeed towards aspen and coniferous forest.

\section{Plant Composition Canopy Cover(\%) MEAN RANGE CONST.}

\section{SHRUBS}

PRICKLY ROSE

(Rosa acicularis)

WILD RED RASPBERRY

$3 \quad 1-5 \quad 100$

$1 \quad 1-2 \quad 100$

(Rubus idaeus)

\section{FORBS}

STRAWBERRY

(Fragaria virginiana)

Clover

(Trifolium spp.

FIREWEED

(Epilobium angustifolium) 8

DANDELION

(Taraxacum officinale) 22

LINDLEY'S ASTER

(Aster ciliolatus)

1

9

$$
1-17
$$$$
100
$$

6

$1-10$

100

GRASSES

MARSH REED GRASS

(Calamagrostis

canadensis)

ТІмотнY

(Phleum pratense)

Blunt SEdge

(Carex obtusata)
0-15 50

14-28 100

$1-2 \quad 100$

$23 \quad 18-27 \quad 100$

$5 \quad 4-5 \quad 100$

$2 \quad 1-3 \quad 100$

\section{ENVIRONMENTAL VARIABLES}

MoISTURE REgIME (MEAN):

(MESIC) TO SUBHYGRIC

NUTRIENT REGIME (MEAN): (MEDIUM) TO RICH

ELEVATION:

853-914 (884)M

SoIl DRAINAGE (MEAN):

MODERATELY WELL TO WELL

Plant Composition:

TAME

DESIRABLE SPECIES SHIFT SCORE: 4

Forage Production(KG/Ha) $\mathrm{n}=2$

$\begin{array}{ll}\text { GRASS } & 1049(594-1504) \\ \text { FORB } & 962(724-1200) \\ \text { SHRUB } & 40(0-80) \\ \text { TOTAL } & 2051(1318-2784)\end{array}$

ECOLOGICALLY SUSTAINABLE STOCKING RATE $0.6 \mathrm{ha} / \mathrm{AUM}(0.5-0.7)$ $0.68 \mathrm{AUM} / \mathrm{ac}(0.8-0.58)$ 


\section{CENTRAL MIXEDWOOD SUBREGION}

\section{DECIDUOUS FOREST COMMUNITY TYPES}

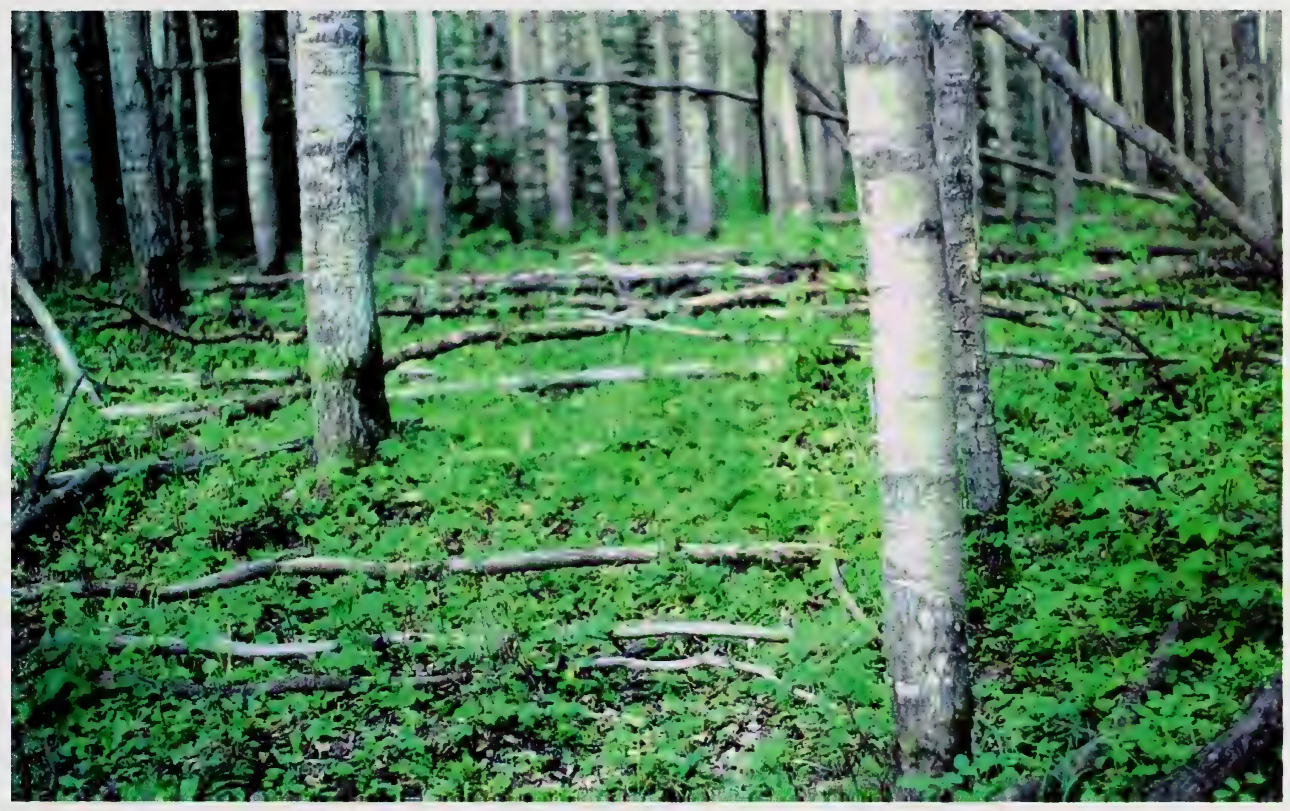

Photo 9. Aw/Rose/Clover community type represents a Central Mixedwood deciduous community that has been moderately to heavily grazed for a number of years. 


\section{DECIDUOUS FOREST COMMUNITIES}

Balsam poplar is most commonly found on moist upland and alluvial bottomland sites; its best growth is on moist rich bottom lands with deep soil (Peterson and Peterson 1992). The nine stands with predominant balsam poplar $(\mathrm{Pb})$ cover represent four community types in the Central Mixedwood subregion. The $\mathrm{Pb}-\mathrm{Aw} /$ River alder community is found on lower slope positions and stream channels where there is seepage throughout the growing season. The $\mathrm{Pb} / \mathrm{Rose}-\mathrm{Alder}, \mathrm{Pb}-$ $\mathrm{Aw} /$ Beaked hazelnut-Rose and $\mathrm{Aw}-\mathrm{Pb} /$ Honeysuckle community types are found upslope on slightly drier and better drained soils. These three community types integrade into the Aw/Rose dominated community types on mesic/medium ecosites.

White birch is indicative of well-drained, sandy or silty loams (Wilkinson 1990). In Alberta this tree is found in association with balsam poplar on moist sites adjacent to small creeks and lowland areas. Pure stands of Alaska variety white birch are also found on dry sandy ridges with high watertables throughout northern Alberta. Beckingham (1993), found that white birch was well adapted to growing on a soil with a $\mathrm{pH}$ of less than 5.3. The White birch/Willow dominated community type maybe indicative of sites with slightly lower $\mathrm{pH}$ 's.

More mesic sites tend to be dominated by aspen and rose. It is the underlying soil conditions and site history that appear to dictate which forb and shrub species will dominate these mesic sites. Blueberry and twinflower appear to indicate sandy soils with poorer nutrient regimes. An abundance of tall forbs (Aw/Rose/Tall forb) appears to be indicative of higher nutrient regimes that have not been disturbed by livestock. In contrast the low forb (Aw/Rose/Low forb) dominated type occupies sites similar to the tall forb type, but these sites appear to have been disturbed by livestock. Increased grazing pressure on these two community types leads to the formation of strawberry and clover dominated community types ( $\mathrm{Pb}-\mathrm{Aw} / \mathrm{Rose} / \mathrm{Strawberry,} \mathrm{Aw/Rose/Clover).}$

Sites that have a more subhygric moisture regime and are moderately well-drained tend to be dominated by willow and alder (Aw/Alder-Willow-Rose, Aw/Willow). The Aw/Rose-Saskatoon community was described on south and west facing slopes overlooking streams and rivers. This community is very similar to the community that was described in the Dry Mixedwood subregion. On sites with rich nutrient regimes red osier dogwood and horsetail dominated communities are very common. The Aw/Horsetail community is usually found on moister sites than the Aw$\mathrm{Pb} /$ Red osier dogwood-Rose community type. 


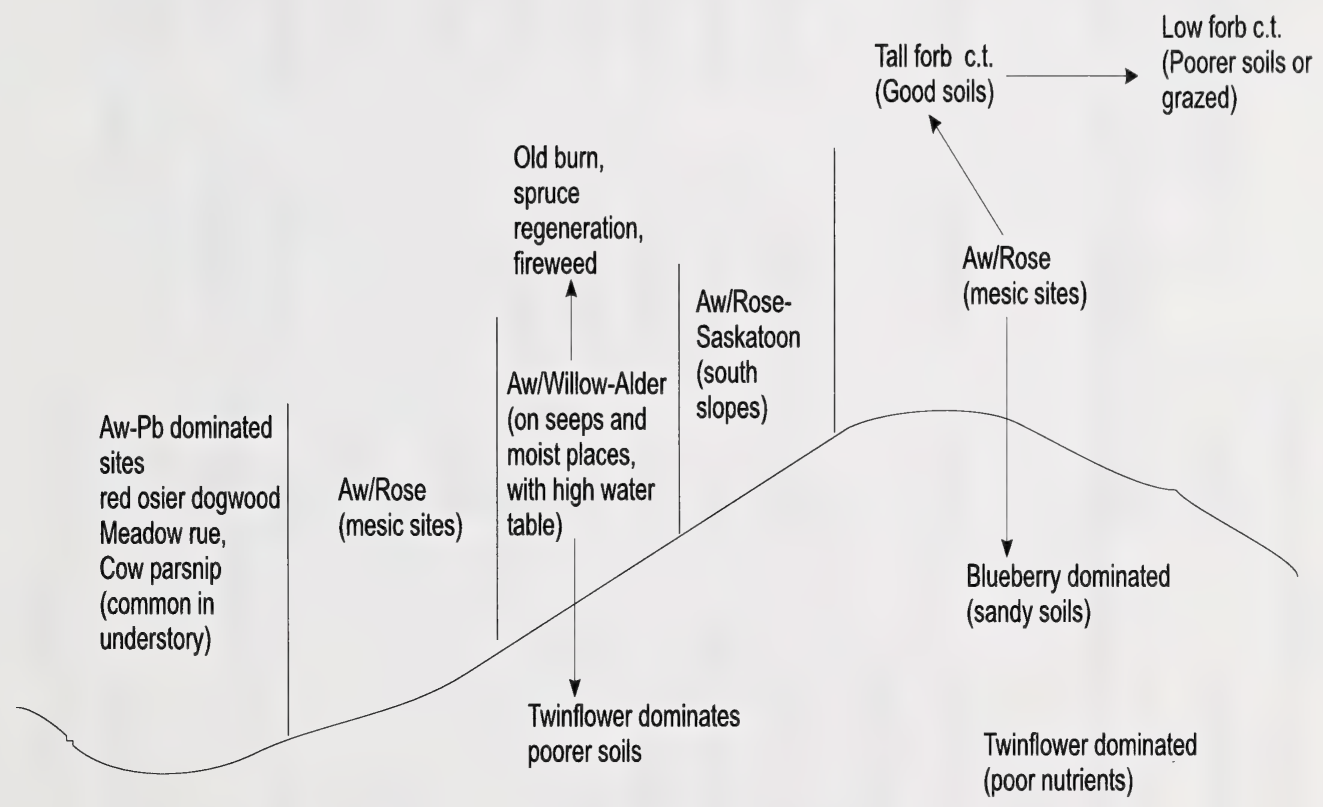

Figure 10. Sequence of Aspen/Rose dominated community types of the Central Mixedwood subregion.

Figure 4 Sequence of Aspen/Rose dominated community types in the landscape of the Central Mixedwood subregion. 


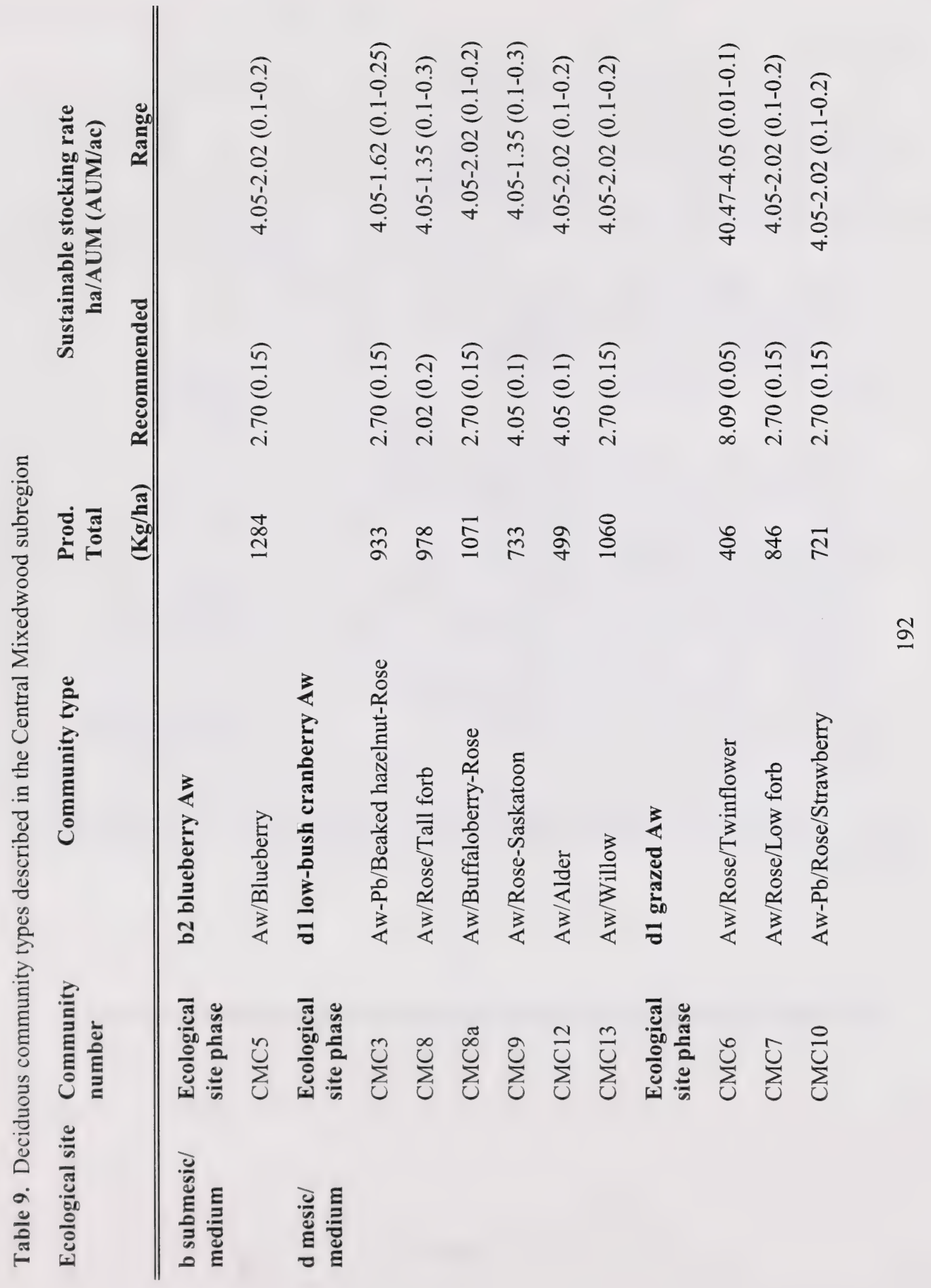




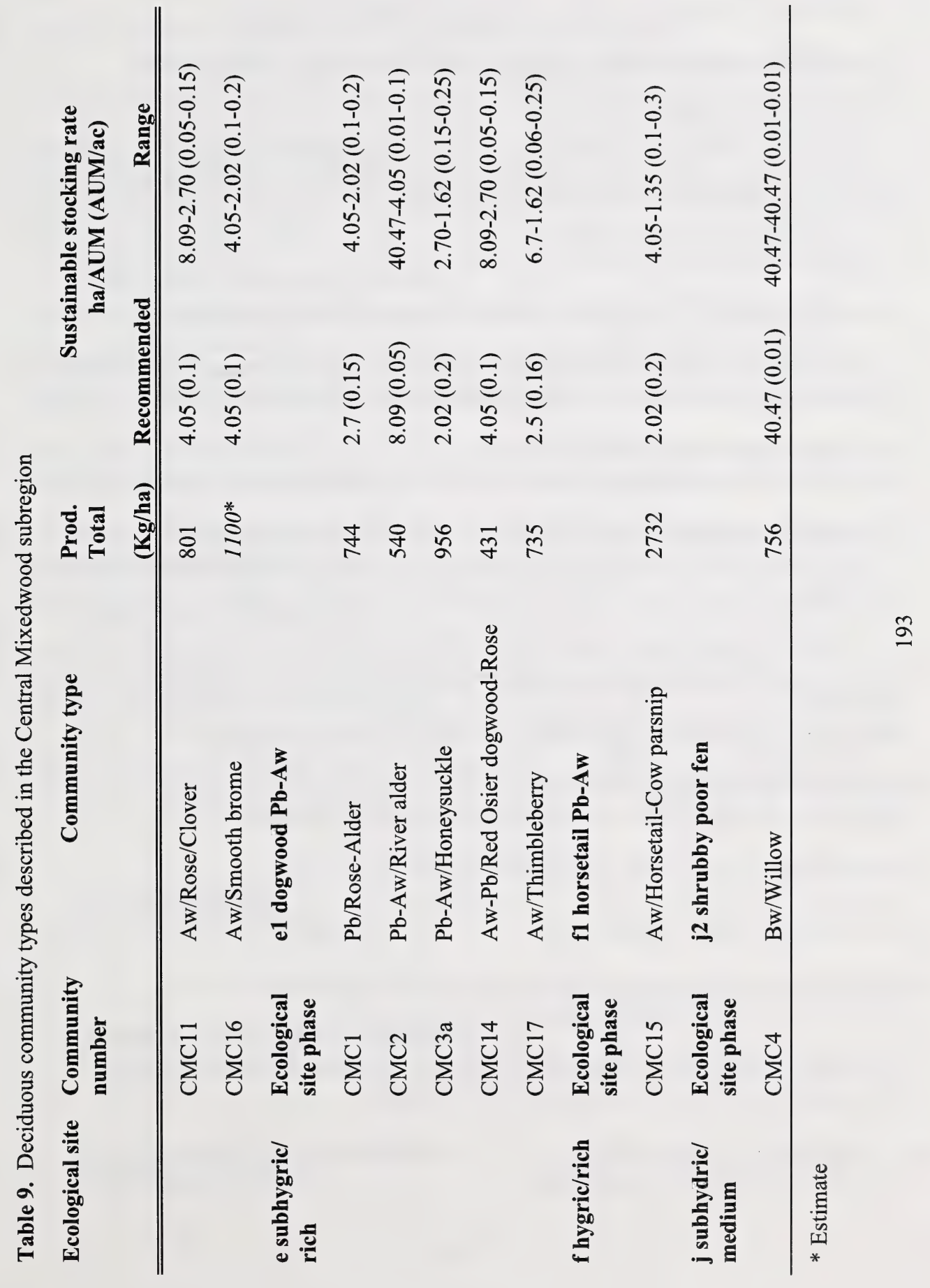




\section{Key to Deciduous Community Types - Central Mixedwood Subregion}

1. Community dominated by balsam poplar or birch, richer, moister sites (aspen may be present but is only co-dominant).

Community dominated by aspen

2. Community dominated by paper birch with willow understory. Bw/Willow (CMC4)

Community dominated by $\mathrm{Pb}, \mathrm{Bw}$ and Aw only minor.

3. Understory dominated by hazelnut, mesic sites

Aw-Pb/Beaked Hazelnut-Rose (CMC3)

Community dominated by green or river alder, honeysuckle or red osier dogwood.

4. Community understory dominated by honeysuckle.

Pb-Aw/Honeysuckle (CMC3a)

Community dominated by river or green alder or red osier dogwood.

5. Community dominated by river or green alder...... 6

Community dominated by red osier dogwood, fluvial floodplains next to rivers

6. Community dominated by green alder, more upland sites with mesic moisture regimes...

Pb/Alder-Rose (CMC1)

Community dominated by river alder, moist seepage areas next to rivers.

Pb-Aw/River Alder (CMC2)

7. Wetter, richer sites, willow, alder, thimbleberry or red osier dogwood dominate the understory.

Mesic sites, rose, saskatoon, buffaloberry, and blueberry dominate understory.

8. Willow or Alder dominates the understory

Red osier dogwood, horsetail, cow parsnip, or thimbleberry dominate

9. Willow dominates understory, alder cover very small, fire origin

10. Red osier dogwood is dominant shrub, rose is co-dominant, community type found on rich fluvial floodplains adjacent to river or stream.

Nutrient rich seepage areas, understory dominated by horsetail, thimbleberry and/or cow parsnip, moist type associated with willow lowlands. 
12. Blueberry dominates shrub layer, rose is co-dominant, dry, sandy soils

Aw/Blueberry (CMC5)

Mesic sites dominated by buffaloberry, rose, or saskatoon.

13. Buffaloberry dominates shrub understory

Aw/Buffaloberry-Rose (CMC8a)

Rose or saskatoon dominate shrub layer.

14. Saskatoon is dominant shrub with rose, community type found on south facing slopes above rivers and streams.

Aw/Rose-Saskatoon (CMC9)

Rose is dominant shrub.

15. Community not modified appreciably by grazing (tall forb dominated - wild sarsaparilla, showy aster, fireweed, peavine).

Aw/Rose/Tall Forb (CMC8)

Community moderately to severely modified by grazing (low forb dominated) or poorer

nutrient sites which are dominated by twinflower or smooth brome. .16

16. Clover common in understory. Aw/Rose/Clover (CMC11)

Clover not common in understory (low forb or smooth brome dominated).

17. Twinflower dominates forb layer, poorer soils

Aw/Rose/Twinflower (CMC6)

Other low forbs (bunchberry, wintergreen, strawberry, wild lily of the valley) or smooth brome dominate understory.

18. Moderately grazed, $\mathrm{Pb}$ in overstory

Aw-Pb/Rose/Strawberry (CMC10)

Primarily aspen overstory, dominated by low forbs (strawberry, bunchberry, wintergreen, etc.), or smooth brome, low cover of shrubs

19. Native understory dominated by low growing forbs. Aw/Rose/Low forb (CMC7)

Smooth brome dominates the understory. Aw/Smooth brome (CMC16) 


\section{CMC1. Pb/Alder-Rose \\ (Populus balsamifera/ Alnus crispa-Rosa acicularis)}

$\mathbf{n}=\mathbf{5}$ This community was found on moderately well-drained sites with subhygric moisture regimes. Beckingham (1993), described a similar community type. He found these forests to develop on parent materials that are neutral to alkaline, thus they tended to have a relatively high level of nutrient availability and potentially high production levels.

This commmunity is producing only a moderate forage base for domestic livestock. Green alder, which makes up a large part of the total forage production for this vegetation type, is generally unpalatable to livestock. This community type would be rated as secondary or non-use range.

\section{Plant Composition Canopy Cover(\%)}

MEAN RANGE CONST.

\section{TREES}

TREMbling Aspen

(Populus tremuloides)

BALSAM POPLAR

(Populus balsamifera)

ShrubS

PRICKLY ROSE

(Rosa acicularis)

GREEN ALDER

(Alnus crispa)

LOW BUSH CRANBERRY

(Viburnum edule)

FORBS

STRAWBERRY

(Fragaria virginiana)

TWINFLOWER

(Linnaea borealis)

NORTHERN BEDSTRAW

(Galium boreale)

TALL LUNGWORT

(Mertensia paniculata)

Creamy Peavine

(Lathyrus ochroleucus)

(Aralia nudicaulis)

Grasses

MARSH REED GRASS

(Calamagrostis canadensis) 8

$\begin{array}{lll}1 & 0-2 & 40 \\ 51 & 10-65 & 100 \\ 16 & 6-28 & 100 \\ 23 & 12-40 & 100 \\ 7 & 0-16 & 80\end{array}$

7

$1-11$

100

1

$0-4$

4

$0-8$

80

4

3-7

100

$4 \quad 1-6 \quad 100$

$4 \quad 0-16 \quad 40$

2-16

\section{ENVIRONMENTAL VARIABLES}

MOISTURE REgIME: SUBHYGRIC

NUTRIENT REGIME: MEDIUM

ELEVATION: $567 \mathrm{M}$

SoIl DRAINAGE: MOderately WeLL

ECOLOGICAL STATUS SCORE: 18

\section{FORAGE PRODUCTION(KG/HA) $\mathrm{n}=5$}

$\begin{array}{ll}\text { GRASS } & 181(0-552) \\ \text { FORBS } & 398(234-978) \\ \text { SHRUBS } & 165(0-250) \\ \text { TOTAL } & 744(474-1530)\end{array}$

ECOLOGICALLY SUSTAINABLE STOCKING RATE $2.70 \mathrm{ha} / \mathrm{AUM}(4.05-2.02)$

0.15 AUM/ac $(0.1-0.2)$ 


\section{CMC2. Pb-Aw/River alder \\ (Populus balsamifera-Populus tremuloides/Alnus tenuifolia)}

$\mathbf{n = 4}$ This community type is found on moist lower slope positions. A similar community type was described on similar sites in the Lower Foothills subregion (Willoughby and Downing 1995). The high cover of alder limits the light reaching the understory and results in low production of grass and forbs. The majority of the total forage production comes from alder which is generally inaccessible and unpalatable to livestock. Consequently this community type would be rated as non-use for domestic livestock.

\section{Plant Composition Canopy Cover $(\%)$} MEAN RANGE CONST.

Trees

TREMBLING ASPEN

(Populus tremuloides) $23 \quad 0-35 \quad 75$

BALSAM POPLAR

(Populus balsamifera) $\quad 26 \quad 19-45 \quad 100$

\section{SHRUBS}

RIVER ALDER

(Alnus tenuifolia)

RED OSIER DOGWOOD

(Cornus stolonifera)

BRACTED HONEYSUCKLE

(Lonicera involucrata)

PRICKLY ROSE

(Rosa acicularis)

LOW BUSH CRANBERRY

(Viburnum edule)

ForbS

HORSETAIL

(Equisetum arvense) $\quad 14 \quad 1-45 \quad 100$

DEWBERRY OR RUNNING RASPBERRY

$\begin{array}{llll}\text { (Rubus pubescens) } & 6 & 1-8 & 100\end{array}$

BISHOP'S CAP

(Mitella nuda)

STRAWBERRY

$\begin{array}{llll}\text { (Fragaria virginiana) } & 3 & 2-4 & 75\end{array}$

LINDLEY'S ASTER

(Aster ciliolatus)

Creamy Peavine

(Lathyrus ochroleucus)

WILD SARSAPARILLA

(Aralia nudicaulis)

Grasses

MARSH REED GRASS

(Calamagrostis canadensis) 1

\section{ENVIRONMENTAL VARIABLES}

MOISTURe Regime:

SUBHYGRIC TO HYGRIC

NUTRIENT REGIME:

RICH

Elevation:

$150-606(454) \mathrm{M}$

Percent Slope Gradient:

$$
0 \text { - } 2
$$

SoIL DRAINAGE:

MODERATELY WELL

ECOLOGICAL STATUS SCORE: 18

FORAGE PRODUCTION(KG/HA) $n=4$

$\begin{array}{ll}\text { GrASS } & 7(2-20) \\ \text { ForBS } & 193(62-376) \\ \text { SHRUBS } & 340(200-438) \\ \text { TOTAL } & 540(202-816)\end{array}$

ECOLOGICALLY SUSTAINABLE STOCKING RATE GeNERALLY NON-USE 8.09 ha/AUM (40.47 - 4.05) $0.05 \mathrm{AUM} / \mathrm{ac}(0.01-0.1)$ 


\section{CMC3. Aw-Pb/Beaked hazelnut-Rose \\ (Populus tremuloides-Populus balsamifera/Corylus cornuta-Rosa acicularis)}

$\mathbf{n = 4}$ This community type was described on south facing slopes and is very similar to the the beaked hazelnut communities described in the Dry Mixedwood subregion. This type appears to occupy warmer and drier microsites that resemble the Dry Mixedwood's climate. The total production of this type is high, but the majority of production is coming from hazelnut which is largely unpalatable to livestock at proper stocking levels. The high cover of hazelnut also restricts access to livestock, limiting the forage availability. This community would be rated as secondary range.

\section{Plant Composition Canopy Cover(\%) MEAN RANGE CONST.}

Trees

TREMBLING ASPEN

(Populus tremuloides) $\quad 33 \quad 25-60 \quad 100$

BALSAM POPLAR

(Populus balsamifera) $\quad 18 \quad 0-65 \quad 75$

SHRUBS

HAZELNUT

(Corylus cornuta)

SASKATOON

(Amelanchier alnifolia)

WILD RED RASPBERRY

(Rubus idaeus)

PRICKLY ROSE

(Rosa acicularis)

FORBS

WILD LILY-OF-THE-VALLEY

(Maianthemum canadense) 3

DEWBERRY OR RUNNING RASPBERRY

(Rubus pubescens)

$6 \quad 0-12 \quad 75$

Creamy Peavine

(Lathyrus ochroleucus) $\quad 3 \quad 1-6 \quad 100$

VEINY MEADOW RUE

(Thalictrum venulosum) $2 \quad 0-3 \quad 75$

WILD SARSAPARILLA

(Aralia nudicaulis)

10

$0-23$

75

Grasses

MARSh ReEd Grass

(Calamagrostis canadensis) $3 \quad 0-9 \quad 50$

MOUNTAIN RICEgRASS

(Oryzopsis asperifolia)

SEDGE

(Carex spp.)

$0-7 \quad 50$

$0-10 \quad 50$

\section{ENVIRONMENTAL VARIABLES}

Moisture Regime:

MESIC TO SUBHYGRIC

NUTRIENT REgIME:

Medium to Rich

ELEVATION: 576-686 (637) M

Percent Slope Gradient: $5-10(7.5) \%$

Soll Drainage: WELL TO MODERATELY WELL

ECOLOGICAL STATUS SCORE: 18

FORAGE PRODUCTION(KG/HA) $\mathrm{n}=4$

GRASS 143(72-370)

FORBS 329(234-310)

SHRUBS 462(152-670)

TOTAL 933(776-1054)

ECOLOGICALLY SUSTAINABLE STOCKING RATE $2.70 \mathrm{ha} / \mathrm{AUM}(4.05-1.62)$

$0.15 \mathrm{AUM} / \mathrm{ac}(0.1-0.25)$ 


\section{CMC3a. Pb-Aw/Honeysuckle \\ (Populus balsamifera-Populus tremuloides /Lonicera involucrata)}

n=5 This community type is represented by one of the Public Lands Peace River benchmark sites. It is a relatively moist and nutrient rich site and represents the honeysuckle ecosite as described by Beckingham and Archibald (1996). The high tree and shrub layer limit the amount of light reaching the forest floor. Consquently, there is little growth of grasses and forbs. Shrub production is largely honeysuckle which is generally unpalatable to domestic livestock. This community type should be rated as secondary range.

\section{Plant Composition Canopy Cover(\%)} MEAN RANGE CONST.

TREES

TREMBLING ASPEN

(Populus tremuloides)

BALSAM POPLAR

(Populus balsamifera) $\quad 46 \quad 20-70 \quad 100$

SHRUBS

HONEYSUCKLE

(Lonicera involcrata)

RED OSIER DOGWOOD

(Cornus stolonifera)

WILD RED RASPBERRY

(Rubus idaeus)

PRICKLY Rose

(Rosa acicularis)

ForBS

FIREWEED

(Epilobium angustifolium) $110-5$

DEWBERRY OR RUNNING RASPBERRY

(Rubus pubescens) 3

(Petasites palmatus)

TALL LUNGWORT

(Mertensia paniculata) $\quad 4 \quad 1-10 \quad 100$

WILD SARSAPARILLA

(Aralia nudicaulis)

Grasses

MARSH REED GRASS

(Calamagrostis canadensis) 7
6

$3 \quad 0-10 \quad 80$

$1 \quad 1-3 \quad 100$

$0-20 \quad 80$

3-10 $\quad 100$

\section{ENVIRONMENTAL VARIABLES}

MOISTURE ReGIME:

SUBHYGRIC

NUTRIENT REGIME:

RICH

ELEVATION:

$869 \mathrm{M}$

SoIL DRAINAGE:

WELL TO MODERATELY WELL

ECOLOGICAL STATUS SCORE: 18

\section{FORAGE PRODUCTION(KG/HA) $n=1$}

$\begin{array}{ll}\text { GRASS } & 151 \\ \text { ForBS } & 288 \\ \text { SHRUBS } & 517 \\ \text { TOTAL } & 956\end{array}$

ECOLOGICALLY SUSTAINABLE STOCKING RATE $2.02 \mathrm{ha} / \mathrm{AUM}(2.70-1.62)$

0.2 AUM/ac (0.15 - 0.25) 


\section{CMC4. Bw/Willow \\ (Betula papyrifera/Salix spp.)}

$\mathbf{n = 1}$ This community type was described on a very moist site that was burned or cleared and is now undergoing succession to a paper birch dominated community type. The understory of this community type is dominated by sphagnum moss, which is characteristic of the poor fen ecosite described by Beckingham and Archibald (1996). The site was likely dominated by black spruce and larch prior to disturbance. The poor nutrient status and very moist conditions make this community type unsuitable for livestock grazing.

\section{Plant Composition Canopy Cover(\%)}

TREES

PAPER BIRCH

(Betula papyrifera)

$55 \quad-\quad 100$

\section{SHRUBS}

WILLOW

(Salix spp.)

$$
50
$$

100

FORBS

SMALL BOG CRANBERRY

(Oxycoccus microcarpus) 25

100

SWAMP HORSETAIL

(Equisetum fluviatile)

MARSH CINQUEFOIL

(Potentilla palustris)

Grasses

MARSh REED GRASS

(Calamagrostis canadensis) 7

HAIR-LIKE SEDGE

(Carex capillaris)

BEAKED SEDGE

(Carex rostrata)

6

100

100

Mosses

PEAT MOSS

(Sphagnum spp.)
93

\section{ENVIRONMENTAL VARIABLES}

Moisture Regime: SUBHYDRIC

NUTRIENT REGIME: MEDIUM

ELEVATION: $576 \mathrm{M}$

SoIl DrainAge: VERY POOR

ECOLOGICAL STATUS SCORE: 18

FORAGE PRODUCTION(KG/HA) $n=1$

GRASS $\quad 340$

FORBS $\quad 342$

SHRUBS $\quad 74$

TOTAL $\quad 756$

ECOLOGICALLY SUSTAINABLE STOCKING RATE GENERALLY NON-USE $40.47 \mathrm{ha} / \mathrm{AUM}(40.47$ - 40.47) 0.01 AUM/ac (0.01-0.01) 


\section{CMC5. Aw/Blueberry \\ (Populus tremuloides/Vaccinium myrtilloides)}

$\mathbf{n = 5} \quad$ This is a very dry, well-drained community type with sandy soil. It is found in conjunction with jack pine stands. Productivity of shrubs is largely blueberry, which is unpalatable to livestock.

These stands tend to be relatively open allowing for easy access by livestock, but the dry site conditions and poorer nutrient status limit the amount of regrowth after grazing. If this community type is managed for one rotation a year, it can contribute significantly to the overall carrying capacity of a lease.

\section{Plant Composition Canopy Cover(\%) MEAN RANGE CONST.}

\section{TREES}

TREMBLING ASPEN

(Populus tremuloides) $\quad 48 \quad 35-65 \quad 100$

\section{SHRUBS}

WILLOW

\section{(Salix spp.)}

WILD RED RASPBERRY

(Rubus idaeus)

BLUEBERRY

(Vaccinium myrtilloides)

PRICKLY Rose

(Rosa acicularis)

FORBS

BUNCHBERRY

(Cornus canadensis)

BEARBERRY

(Arctostaphylos uva-ursi)

YELLOW PEAVINE

(Lathyrus ochroleucus)

TWINFLOWER

(Linnaea borealis)

STRAWBERRY

$\begin{array}{llll}\text { (Fragaria virginiana) } & 3 & 1-5 & 100\end{array}$

Grasses

PURPLE OAT GRASS

(Schizachne purpurascens) 2

HAIRY WILD RYE

(Elymus innovatus)

MOUNTAIN RICEGRASS

(Oryzopsis asperfolia)

\begin{tabular}{lll}
6 & $0-20$ & 60 \\
1 & $0-5$ & 40 \\
9 & $11-37$ & 100 \\
7 & $1-16$ & 100 \\
3 & $0-13$ & 20 \\
4 & $1-8$ & 100 \\
4 & $0-7$ & 80 \\
3 & $1-5$ & 100 \\
\hline 2 & $0-6$ & 80 \\
\hline 4 & $0-10$ & 80 \\
\hline 2 & $0-7$ & 60 \\
\hline
\end{tabular}

\section{ENVIRONMENTAL VARIABLES}

Moisture Regime:

SUBMESIC

NUTRIENT REgime:

MEDIUM

ELEVATION:

$600-909(682) \mathrm{M}$

SOIL DRAINAGE:

WELL

ECOLOGICAL STATUS SCORE: 18

FORAGE PRODUCTION(KG/HA) $n=5$

$\begin{array}{ll}\text { GRASS } & 913(98-1794) \\ \text { FORBS } & 230(0-388) \\ \text { SHRUBS } & 205(0-452) \\ \text { TOTAL } & 1284(762-1794)\end{array}$

ECOLOGICALLY SUSTAINABLE STOCKING RATE $2.70 \mathrm{ha} / \operatorname{AUM}(4.05-2.02)$

$0.15 \mathrm{AUM} / \mathrm{ac}(0.1-0.2)$ 


\section{CMC6. Aw/Rose/Twinflower \\ (Populus tremuloides/Rosa acicularis/Linnaea borealis)}

$\mathbf{n}=\mathbf{6}$ This community type has been grazed moderately to heavily and is very similar to the grazed $\mathrm{Pb} / \mathrm{Rose} / \mathrm{Strawberry}$ and Aw/Rose/Low forb community types. Grazing pressure reduces the cover of shrubs and tall-growing forbs and allows the low-growing forbs to increase in cover. This community type occupies soils with poor nutrient regimes. The poor nutrient status appears to favour the growth of twinflower, a species that is well adapted to growing on poor soils (Corns and Annas 1986). This may explain why twinflower is predominant on this community type and not on the other grazed community types.

\section{Plant Composition Canopy Cover(\%)

MEAN RANGE CONST.

\section{TREES}

BALSAM POPLAR

(Populus balsamifera) $\quad 3 \quad 0-15 \quad 17$

TREMBLing AsPen

(Populus tremuloides) $\quad 53 \quad 25-75 \quad 100$

SHRUBS

PRICKLY Rose

(Rosa acicularis)

WILD RED RASPBERRY

(Rubus idaeus)

LOW BUSH CRANBERRY

(Viburnum edule)

SNOWBERRY OR BUCKBRUSH

(Symphoricarpos

occidentalis)

FORBS

Creamy Peavine

(Lathyrus ochroleucus)

BUNCHBERRY

$\begin{array}{llll}\text { (Cornus canadensis) } & 5 & 1-10 & 100\end{array}$

TWINFLOWER

(Linnaea borealis)

STRAWBERRY

(Fragaria virginiana)

WINTERGREEN

(Pyrola asarifolia)

$11 \quad 6-18 \quad 100$

$1 \quad 0-1 \quad 50$

$2 \quad 0-7 \quad 83$

GRASSES

MOUNTAIN RICEGRASS

(Oryzopsis asperifolia)

HAIRY WILD RYE

(Elymus innovatus)

PuRPle OAT GRass

(Schizachne purpurascens)

KENTUCKY BLUEGRASS

(Poa pratensis)

$3 \quad 1-5 \quad 100$

$3 \quad 1-7 \quad 100$

19

11-31 100

5

$2-9 \quad 100$

$\begin{array}{lll}1 & 0-7 & 33\end{array}$

3

$0-5 \quad 83$

$0-5 \quad 83$

$0-6 \quad 83$
$3 \quad 1-7 \quad 100$

\section{ENVIRONMENTAL VARIABLES}

MOISTURE REgIME:

\section{SubMesic to Mesic}

NUTRIENT REGIME:

MEDIUM

ELEVATION:

$579-733$ (634) M

Percent Slope Gradient: $2(0-5) \%$

Soll DRAINAGE: WELL

ECOLOGICAL STATUS SCORE: 12

FORAGE PRODUCTION(KG/HA) $\mathrm{n}=6$

GRASS 56(6-134)

FORBS 230(70-464)

SHRUBS 120(16-294)

TOTAL 406(190-692)

ECOLOGICALLY SUSTAINABLE STOCKING RATE $8.09 \mathrm{ha} / \mathrm{AUM}(40.47-4.05)$ $0.05 \mathrm{AUM} / \mathrm{ac}(0.01-0.1)$ 


\section{CMC7. Aw/Rose/Low forb \\ (Populus tremuloides/Rosa acicularis/Low forb)}

$\mathbf{n = 2 3}$ This type occupies mesic, well-drained sites with medium nutrient regimes. This type is similar to the Aw/Rose/Tall forb community type, but this type appears to occupy drier sites with poorer nutrient regimes. It has also been observed that this type can also be produced when the tall forb community is grazed for a number of years. The increased grazing pressure may explain why the production on this type is lower than the tall forb type. Forage production in this type is good, but the low-growing forbs are not as accessible to livestock as the tall growing forbs.

\section{Plant Composition Canopy Cover(\%)}

MEAN RANGE CONST.

TREES

TREMBLING ASPEN

BALSAM POPLAR

(Populus balsamifera)

WHITE SPRUCE

(Picea glauca)

ShrubS

SASKATOON

(Amelanchier alnifolia)

PRICKLY ROSE

(Rosa acicularis)

WILD RED RASPBERRY

(Rubus idaeus)

SNOWBERRY

(Symphoricarpos

occidentalis)

LOW BUSH CRANBERRY

(Viburnum edule)

FORBS

STRAWBERRY

(Fragaria virginiana)

FIREWEED

(Epilobium angustifolium)

CREAMY PEAVINE

$\begin{array}{llll}\text { (Lathyrus ochroleucus) } & 3 & 0-11 & 87\end{array}$

DEWBERRY OR RUNNING RASPBERRY

(Rubus pubescens)

(Aster ciliolatus)

BUNCHBERRY

(Cornus canadensis)

Grasses

MARSH REED GRASS

(Calamagrostis canadensis)5

HAIRY WILD RYE

(Elymus innovatus)

$3 \quad 0-10 \quad 80$

$\begin{array}{lll}3 & 0-8 & 78\end{array}$

6

$0-18$

92

$50 \quad 25-70 \quad 100$

$0-20 \quad 30$

0-8 $\quad 40$

0-16 $\quad 70$

4-42 $\quad 100$

0-23 70

0-36 74

$0-9 \quad 78$

$1-10 \quad 100$

0-10 61

80

78

0-20 $\quad 87$

0-12 70

\section{ENVIRONMENTAL VARIABLES}

MoIsture Regime:

MESIC

NUTRIENT REGIME:

Medium

ELEVATION:

579-667 (649) M

PERCENT SLOPE GRADIENT: $3(0-15) \%$

ASPECT:

VARIABLE

SoIL DRAINAGE: WELL TO MODERATELY WELL

ECOLOGICAL STATUS SCORE: 12

\section{FORAGE PRODUCTION(KG/HA) $\mathbf{n}=22$}

$\begin{array}{ll}\text { GRASS } & 288(6-660) \\ \text { FORBS } & 312(76-830) \\ \text { SHRUBS } & 255(38-1154) \\ \text { TOTAL } & 846(312-2086)\end{array}$

ECOLOGICALLY SUSTAINABLE STOCKING RATE $2.70 \mathrm{ha} / \mathrm{AUM}(4.05-2.02)$

$0.15 \mathrm{AUM} / \mathrm{ac}(0.1-0.2)$ 


\section{CMC8. Aw/Rose/Tall forb \\ (Populus tremuloides/Rosa acicularis/Tall forb)}

$\mathbf{n = 2 3}$ This type appears to be the modal aspen community type in the absence of disturbance on mesic, medium to rich sites. The presence of tall forbs wild sarsaparilla, fireweed, and peavine distinguish this community from the low forb type. It is unclear why there is a difference in the tall and low forb types. Corns and Annas (1986) recoqnized the two types in the Lower Foothills subregion. They felt the wild sarsaparilla type was moister and had a higher nutrient regime. It has also been observed that the low forb type can be produced when the tall forb community is lightly to moderately grazed for a number of years (Willoughby 1996).

The forage production on this community type is good. The majority of the vegetation is palatable to livestock. This community type would be rated as primary range for domestic livestock. Wild sarsaparilla, a major component of this community type appears to be very sensitive to any disturbance by livestock.

\section{Plant Composition Canopy Cover(\%) \\ MEAN RANGE CONST.}

TREES

BALSAM POPLAR

(Populus balsamifera)

TREMBling AsPen

(Populus tremuloides)

SHRUBS

RED OSIER DOGWOOD

(Cornus stolonifera)

WILD RED RASPBERRY

(Rubus ideaus)

PRICKLY ROSE

(Rosa acicularis)

LOW BUSH CRANBERRY

(Viburnum edule)

FORBS

WILD SARSAPARILLA

(Aralia nudicaulis)

CREAMY PEAVINE

(Lathyrus ochroleucus)

DEWBERRY

(Rubus pubescens)

LINDLEY'S ASTER

(Aster ciliolatus)

FIREWEED

(Epilobium angustifolium)

STRAWBERRY

(Fragaria virginiana)

Grasses

Marsh ReEd Grass

(Calamagrostis canadensis) 8

$\begin{array}{lll}7 & 0-30 & 44 \\ 54 & 10-75 & 100\end{array}$

$\begin{array}{lll}2 & 0-7 & 48\end{array}$

$2 \quad 0-5 \quad 70$

$15 \quad 5-33 \quad 100$

$11 \quad 0-26 \quad 87$

$15 \quad 0-69 \quad 96$

$4 \quad 1-12 \quad 100$

$5 \quad 0-15 \quad 91$

$2 \quad 0-2 \quad 78$

$5 \quad 0-19 \quad 83$

$3 \quad 0-9 \quad 87$

$2-21 \quad 100$

\section{ENVIRONMENTAL VARIABLES}

MoISTURE REgIME:

Mesic

NUTRIENT REgIME:

MEdium To RICH

ELEVATION:

576-909 (683)M

SoIl Drainage:

WELL

ECOLOGICAL STATUS SCORE: 18

FORAGE PRODUCTION(KG/HA) $n=21$

$\begin{array}{ll}\text { GRASS } & 216(3-812) \\ \text { FORBS } & 466(179-1014) \\ \text { SHRUBS } & 296(60-1058) \\ \text { TOTAL } & 978(459-1602)\end{array}$

ECOLOGICALLY SUSTAINABLE STOCKING RATE $2.02 \mathrm{ha} / \mathrm{AUM}(4.05-1.35)$ 0.2 AUM/ac $(0.1-0.3)$ 


\section{CMC8a. Aw/Buffaloberry-Rose \\ (Populus tremuloides/Shepherdia canadensis-Rosa acicularis)}

$\mathbf{n = 2}$ This community type was found on a mesic site at higher elevations in the Central Mixedwood subregion west of Beaverlodge. Beckingham (1993) felt the Aw/Buffaloberry type was slightly drier and had a slightly poorer nutrient regime than the modal Aw/Rose community types. This type is providing a moderate amount of forage for domestic livestock, but the drier site conditions and poorer nutrient status will limit regrowth after grazing. Buffaloberry the predominant shrub species in this community type, is generally unpalatable to livestock.

\section{Plant Composition Canopy Cover(\%) \\ MEAN RANGE CONST.}

Trees

TREMBLING ASPEN

(Populus tremuloides)

WHITE SPRUCE

(Picea glauca)

SHRUBS

BUFFALOBERRY

(Shepherdia canadensis)

PRICKLY ROSE

(Rosa acicularis)

LOW BUSH CRANBERRY

(Viburnum edule)

ForBS

BUNCHBERRY

(Cornus canadensis)

CREAMY PEAVINE

(Lathyrus ochroleucus)

DEWBERRY

$\begin{array}{llll}\text { (Rubus pubescens) } & 2 & 2-2 & 100\end{array}$

FIREWEED

$\begin{array}{llll}\text { (Epilobium angustifolium) } & 3 & 0-6 & 50\end{array}$

STRAWBERRY

$\begin{array}{llll}\text { (Fragaria virginiana) } & 2 & 1-4 & 100\end{array}$

Grasses

MARSH REED GRASS

(Calamagrostis canadensis)2

\section{ENVIRONMENTAL VARIABLES}

Moisture Regime:

MESIC

NUTRIENT REGIME: MEDIUM TO POOR

ELEVATION: $701-800(750) \mathrm{M}$

SOIL DRAINAGE:

WELL

ECOLOGICAL STATUS SCORE: 18

\section{FORAGE PRODUCTION(KG/HA) $\mathrm{n}=2$}

$\begin{array}{ll}\text { GRASS } & 230(60-400) \\ \text { FORBS } & 476(364-588) \\ \text { SHRUBS } & 365(200-531) \\ \text { TOTAL } & 1071(955-1188)\end{array}$

ECOLOGICALLY SUSTAINABLE STOCKING RATE $2.70 \mathrm{ha} / \mathrm{AUM}(4.05-2.02)$

0.15 AUM/ac $(0.1-0.2)$ 


\section{CMC9. Pb-Aw/Rose-Saskatoon}

(Populus balsamifera-Populus tremuloides/Rosa acicularis-Amelanchier alnifolia)

$\mathbf{n = 4} \quad$ This community type is found on mesic, well drained south facing slopes that overlook rivers and creeks. This community is also similar to the Aw/Saskatoon-Rose community that was described in the Dry Mixedwood subregion. Both community types occur on south and west facing slopes. Saskatoon provides important browse for wild ungulates. Livestock also find saskatoon palatable and in areas where there is extensive cattle grazing this species can be heavily browsed.

\section{Plant Composition Canopy Cover(\%) \\ MEAN RANGE CONST.}

\section{TREES}

TREMBLING ASPEN

(Populus tremuloides)

BALSAM POPLAR

$\begin{array}{llll}\text { (Populus balsamifera) } & 14 & 0-45 & 75\end{array}$

SHRUBS

PRICKLY ROSE

(Rosa acicularis)

SASKATOON

(Amelanchier alnifolia) $\quad 25 \quad 11-45 \quad 100$

SNOWBERRY

(Symphoricarpos

occidentalis)

RIVER ALDER

(Alnus tenuifolia)

WILLOW

(Salix spp.)

FORBS

HORSETAIL

(Equisetum arvense)

BUNCHBERRY

(Cornus canadensis)

LINDLEY'S ASTER

(Aster ciliolatus)

DEWBERRY

(Rubus pubescens)

CREAMY PEAVINE

$\begin{array}{llll}\text { (Lathyrus ochroleucus) } & 4 & 0-8 & 75\end{array}$

STRAWBERRY

$\begin{array}{llll}\text { (Fragaria virginiana) } & 6 & 1-14 & 100\end{array}$

Grasses

MOUNTAIN RICEGRASS

(Oryzopsis asperifolia)

MARSH REED GRASS

(Calamagrostis canadensis) 7

\section{ENVIRONMENTAL VARIABLES}

MoISTURE REgIME:

MESIC

NUTRIENT REGIME:

MEDIUM

ELEVATION:

$606 \mathrm{M}$

SOIL DRAINAGE:

WELL TO RAPIDLY

SLOPE:

$26(2-50) \%$

ASPECT:

WESTERLY

ECOLOGICAL STATUS SCORE: 18

FORAGE PRODUCTION(KG/HA) n=4

$\begin{array}{ll}\text { GRASS } & 203(0-290) \\ \text { FORBS } & 312(240-488) \\ \text { SHRUBS } & 218(10-227) \\ \text { TOTAL } & 733(250-1014)\end{array}$

ECOLOGICALLY SUSTAINABLE STOCKING RATE $4.05 \mathrm{ha} / \mathrm{AUM}(4.05-1.35)$

$0.1 \mathrm{AUM} / \mathrm{ac}(0.1-0.3)$ 


\section{CMC10. Aw-Pb/Rose/Strawberry \\ (Populus tremuloides-Populus balsamifera/Rosa acicularis/Fragaria virginiana)}

$\mathbf{n = 2}$ This community type appears to have been moderately grazed in the past. As grazing pressure becomes heavy, there is a reduction in shrub, tall forbs and native grass cover and an increase in cover of low growing forbs(dandelion and strawberry). Continued heavy grazing pressure eventually leads to a decline in all native plants and Kentucky bluegrass, clover and dandelion will predominate in the understory (Willoughby 1996). The forage production on this community type is only moderate and is slightly less than other $\mathrm{Aw}$ and $\mathrm{Pb}$ dominated community types. A period of rest would greatly benefit the production on this community type.

\section{Plant Composition Canopy Cover(\%)}

Trees

BALSAM POPLAR

(Populus balsamifera) $28 \quad 20-35 \quad 100$

TREMBLING ASPEN

(Populus tremuloides) $\quad 45 \quad 40-50 \quad 100$

SHRUBS

PRICKLY ROSE

(Rosa acicularis)

RED OSIER DOGWOOD

(Cornus stolonifera)

SNOWBERRY OR BUCKBRUSH

(Symphoricarpos

occidentalis)

FORBS

STRAWBERRY

$\begin{array}{llll}\text { (Fragaria virginiana) } & 10 & 3-16 & 100\end{array}$

DANDELION

(Taraxacum officinale) $\quad 3 \quad 2-3 \quad 100$

DEWBERRY OR RUNNING RASPBERRY

(Rubus pubescens)

(Galium boreale)

LINDLEY'S ASTER

(Aster ciliolatus)

Creamy Peavine

(Lathyrus ochroleucus)

$1-2$

100

$3 \quad 2-3 \quad 100$

GrasSES

MARSH REEd GRASS

(Calamagrostis canadensis) 1

\section{ENVIRONMENTAL VARIABLES}

MoIsture Regime: Mesic To SUBHYGRIC

NUTRIENT REGIME: MEdIUM

ELEVATION: 576-606 (578) M

Percent Slope Gradient: LEVEL

SoIL DRAINAGE: WELL TO MODERATELY WELL

ECOLOGICAL STATUS SCORE: 12

FORAGE PRODUCTION(KG/HA) $\mathrm{n}=2$

$\begin{array}{ll}\text { GrASS } & 309(0-617) \\ \text { ForBS } & 333(142-524) \\ \text { SHRUBS } & 80(23-136) \\ \text { TOTAL } & 721(660-782)\end{array}$

ECOLOGICALLY SUSTAINABLE STOCKING RATE $2.70 \mathrm{ha} / \mathrm{AUM}(4.05-2.02)$ $0.15 \mathrm{AUM} / \mathrm{ac}(0.1-0.2)$ 


\section{CMC11. Aw/Rose/Clover (Populus tremuloides/Rosa acicularis/Trifolium spp.)}

$\mathbf{n = 3}$ This community type is represented by aspen stands that have recieved moderate to heavy grazing pressure for a number of years. As a result, native forbs have declined and clover has increased in the understory. A small portion of the original shrub and tall forb understory still remains. Although, grass production has dropped, forb production remains high due to the dense cover of clover. This community has not been grazed as long as the Aw/Kentucky bluegrass/Clover community type (Willoughby 1996).

\section{Plant Composition Canopy Cover(\%) MEAN RANGE CONST.}

\section{TREES}

TREMBLING ASPEN

(Populus tremuloides)

BALSAM POPLAR

(Populus balsamifera)

SHRUBS

WILD RED RASPBERRY

(Rubus idaeus)

PRICKLY ROSE

(Rosa acicularis)

FORBS

Clover

(Trifolium sp.)

DANDELION

(Taraxacum officinale)

STRAWBERRY

(Fragaria virginiana)

HORSETAIL

(Equisetum arvense) 2

WILD LILY-OF-THE-VALLEY

(Maianthemum canadense) 1

Grasses

MARSH REED GRASS

(Calamagrostis canadensis)

KENTUCKY BLUEGRASS

(Poa pratensis)

CREEPING RED FESCUE

(Festuca rubra)

HAIRY WILD RYE

(Elymus innovatus)

52

$30-65 \quad 100$

6

$0-18$

33

3

$0-4$

67

19

$5-38$

100

12

8-18

100

5

4-6

100

3

$1-4$

100

$0-4 \quad 33$

$1-2 \quad 100$

$1-8$

100

$0-10$

67

2

$0-4$

67

2

\section{ENVIRONMENTAL VARIABLES}

Moisture Regime:

MESIC

NUTRIENT REgime:

MEDIUM

ELEVATION:

$606-716$ (669) M

SOIL DRAINAGE:

WELL

ECOLOGICAL STATUS SCORE: 6

\section{FORAGE PRODUCTION(KG/HA) n=3}

$\begin{array}{ll}\text { GRASS } & 344(260-512) \\ \text { FORBS } & 167(130-192) \\ \text { SHRUBS } & 205(172-226) \\ \text { TOTAL } & 801(606-930)\end{array}$

ECOLOGICALLY SUSTAINABLE STOCKING RATE 4.05 ha/AUM $(8.09-2.70)$

$0.1 \mathrm{AUM} / \mathrm{ac}(0.05-0.15)$ 


\section{CMC12. Aw/Alder \\ (Populus tremuloides/ Alnus crispa)}

$\mathbf{n = 1 4}$ This community type is scattered throughout the Central Mixedwood subregion on mainly mesic to subhygric, well-drained sites. This community is likely of fire origin. Many of the plots were described from a large fire that burned through the area in 1968. The aspen trees are also young and very dense. The high cover of aspen, alder, and willow limits the amount of light reaching the understory. Consequently, there is little forage available for domestic livestock. This community type would be rated as secondary or non-use range.

\section{Plant Composition Canopy Cover(\%) MEAN RANGE CONST.}

\section{Trees}

Trembling Aspen

(Populus tremuloides) $\quad 60 \quad 30-90 \quad 100$

\section{SHRUBS}

PRICKLY Rose

(Rosa acicularis)

BLUEBERRY

(Vaccinium myrtilloides) $1 \quad 0-2 \quad 31$

WILLOW

(Salix spp.)

GREEN ALDER

(Alnus crispa)

FORBS

BUNCHBERRY

(Cornus canadensis) $\quad 10 \quad 0-26 \quad 92$

STRAWBERRY

$\begin{array}{llll}\text { (Fragaria virginiana) } & 2 & 0-6 & 61\end{array}$

TWINFLOWER

(Linnaea borealis)

DEWBERRY

WILD LILY-OF-THE-VALLEY

(Maianthemum canadense) 2

Creamy Peavine

(Lathyrus ochroleucus) 2

GRASSES

MARSH REED GRASS

(Calamagrostis canadensis)5 $0-19 \quad 92$

HAIRY WILD RYE

(Elymus innovatus)

MOUNTAIN RICEGRASS

(Oryzopsis asperfolia)

$12 \quad 0-43 \quad 61$

$34 \quad 13-85 \quad 100$

$11 \quad 0-45 \quad 85$

0-10 $\quad 85$

0-6 $\quad 77$

$0-9 \quad 69$

$0-2 \quad 39$

$0-2 \quad 15$

\section{ENVIRONMENTAL VARIABLES}

MoIsture Regime:

MESIC TO SUBHYGRIC

NUTRIENT REgIME:

MEDIUM TO RICH

ELEVATION:

333-758 (635) M

PERCENT Slope Gradient:

$5(0-15) \%$

SoIl DRAINAGE:

WELL TO MODERATELY WELL

ECOLOGICAL STATUS SCORE: 18

\section{FORAGE PRODUCTION(KG/HA) $\mathrm{n}=14$}

$\begin{array}{ll}\text { GRASS } & 75(8-350) \\ \text { FORBS } & 200(2-476) \\ \text { SHRUBS } & 225(5-660) \\ \text { TOTAL } & 499(100-930)\end{array}$

ECOLOGICALLY SUSTAINABLE STOCKING RATE $4.05 \mathrm{ha} / \mathrm{AUM}(4.05$ - 2.02) $0.1 \mathrm{AUM} / \mathrm{ac}(0.1-0.2)$ 


\section{CMC13. Aw/Willow \\ (Populus tremuloides/Salix spp.)}

$\mathbf{n = 7}$ This community type is similar to the Aw/Alder-Willow-Rose community type, but lacks the cover of alder. Previously, this community type was split into four community types (Willoughby and Downing 1995). These included the Aw/Willow-Rose/Twinflower, Aw/Willow-Rose/Bunchberry, Aw/Rose-Willow-Pin cherry/Fireweed and Aw/Rose-Willow-Saskatoon. All four community types appeared to have had a fire origin, but had slightly different moisture and nutrient regimes which affected forage productivity. Productivity varied from 1326 to 1306 $\mathrm{kg} / \mathrm{ha}$ on the Aw/Willow-Rose/Bunchberry and Aw/Rose-Willow-Pin cherry/Fireweed types to $606 \mathrm{~kg} / \mathrm{ha}$ on the Aw/Willow-Rose/Twinflower type. Because the sample size was so small it was felt to be impractical to split the four community types and they were lumped into this one type for the purpose of this guide. As this community undergoes succession forage productivity will decline.

\section{Plant Composition CanopyCover(\%) \\ MEAN RANGE CONST.}

TREES

TREMBLING ASPEN

(Populus tremuloides)

SHRUBS

PRICKLY ROSE

(Rosa acicularis)

WILLOW SPP.

(Salix spp.)

LOW BUSH CRANBERRY

(Viburnum edule)

ForbS

BUNCHBERRY

(Cornus canadensis)

(Aralia nudicaulis)

Creamy Peavine

(Lathyrus ochroleucus)

DEWBERRY

(Rubus pubescens)

WILD LILY-OF-THE-VALLEY

(Maianthemum canadense) 4

FIREWEED

$\begin{array}{lll}\text { (Epilobium angustifolium) } 7 & 0-32 & 86\end{array}$

TWINFLOWER

(Linnaea borealis)

Grasses

MARSh ReEd GRass

(Calamagrostis canadensis) 9

HAIRY WILD RYE

(Elymus innovatus)
$46 \quad 35-68 \quad 100$

$15 \quad 11-21 \quad 100$

$25 \quad 15-35 \quad 100$

$3 \quad 0-12 \quad 57$

$8 \quad 0-30 \quad 86$

$5 \quad 0-18 \quad 43$

$4 \quad 1-10 \quad 100$

$8 \quad 2-12 \quad 100$

3-11 100

$0-11 \quad 71$

$1-17 \quad 100$

$0-10 \quad 57$

\section{ENVIRONMENTAL VARIABLES}

MoISTURE REgIME: MESIC TO SUBHYGRIC

NUTRIENT REGIME: MEDIUM TO RICH

ELEVATION: 333-901 (631) M

SoIl DRAINAGE: WELl TO MODERATELY WELL

ECOLOGICAL STATUS SCORE: 18

FORAGE PRODUCTION(KG/HA) $n=6$

Grass 420(2-708)

FORBS 446(262-552)

SHRUBS 193(107-378)

TotAL 1060(606-1367)

ECOLOGICALLY SUSTAINABLE STOCKING RATE $2.70 \mathrm{ha} / \mathrm{AUM}(4.05-2.02)$

$0.15 \mathrm{AUM} / \mathrm{ac}(0.1-0.2)$ 


\section{CMC14. Aw-Pb/Red osier dogwood-Rose \\ (Populus tremuloides-P. balsamifera/Cornus stolonifera-Rosa acicularis)}

$\mathbf{n = 1 1}$ This community is typical of river floodplains throughout the Central Mixedwood subregion. This community has a subhygric moisture and rich nutrient regime. Beckingham and Archibald (1996) found this community type on mid to lower slope topographic positions or near water courses where they recieve nutrient-rich seepage or flood waters for a portion of the growing season. This community type is one of the most productive in the Central Mixedwood, but the high cover of shrubs limits access to livestock. The high cover of tall growing shrubs (alder, red osier dogwood) also limits the growth of low shrubs, forbs and grass the principle forage species for domestic livestock in deciduous forests. As a result, this community should be rated as secondary or non-use range.

\section{Plant Composition Canopy Cover(\%) \\ MEAN RANGE CONST.}

TrEes

TREMBLING AsPen

(Populus tremuloides)

38

BALSAM POPLAR

(Populus balsamifera)

SHRUBS

PRICKLY ROSE

(Rosa acicularis)

RED OSIER DOGWOOD

(Cornus stolonifera)

LOW BUSH CRANBERRY

(Viburnum edule)

FORBS

LADY FERN

(Athyrium filix-femina)

WILD SARSAPARILLA

(Aralia nudicaulis)

DEWBERRY

(Rubus pubescens)

WILD LILY-OF-THE-VALLEY

(Maianthemum canadense) 2

Creamy Peavine

(Lathyrus ochroleucus) 3

TALL LUNGWORT

(Mertensia paniculata) 3

Grasses

MARSH REED GRASS

(Calamagrostis canadensis) 8

\section{ENVIRONMENTAL VARIABLES}

Moisture Regime: SUBHYGRIC

NUTRIENT REgIME: $\mathrm{RICH}$

ELEVATION: 600-606 (604)M

SLOPE PERCENT: $2(1-3) \%$

SoIl Drainage: MODERATELY WELL

ECOLOGICAL STATUS SCORE: 18

\section{FORAGE PRODUCTION(KG/HA) $\mathrm{n}=5$}

$\begin{array}{ll}\text { GrASS } & 6(2-22) \\ \text { ForBS } & 212(66-372) \\ \text { SHRUBS } & 214(20-358) \\ \text { TOTAL } & 431(226-714)\end{array}$

ECOLOGICALLY SUSTAINABLE STOCKING RATE Generally NON-USE 4.05 ha/AUM (8.09 - 2.70)

0.1 AUM/ac (0.05 - 0.15) 


\section{CMC15. Aw/Horsetail-Cow parsnip (Populus tremuloides/Equisetum arvense-Heracleum lanatum)}

$\mathbf{n}=\mathbf{1}$ This community type occupies lowland sites adjacent to black spruce and willow lowlands. It is very moist and nutrient rich. Horsetail types in other subregions also tend to be moister and richer than the modal Aw/Rose types. This site is very productive and produces a large amount of forage for domestic livestock. Horsetail is generally unpalatable to livestock and can be poisonous to horses. In contrast cow parsnip is very palatable to livestock. This community type would therefore be rated as primary or secondary range for domestic livestock.

\section{Plant Composition Canopy Cover(\%)}

MEAN RANGE CONST.

TREES

TREMBLING ASPEN

(Populus tremuloides) $12 \quad-\quad 100$

SHRUBS

WILD RED RASPBERRY

(Rubus idaeus)

FORBS

COW PARSNIP

(Heracleum lanatum) $\quad 30 \quad$ - $\quad 100$

FIREWEED

(Epilobium angustifolium) $1 \quad 100$

HORSETAIL

$\begin{array}{lll}\text { (Equisetum arvense) } & 25 & -\end{array}$

TALL LUNGWORT

$\begin{array}{llll}\text { (Mertensia paniculata) } & 18 & - & 100\end{array}$

TALL LARKSPUR

(Delphinium glaucum) $\quad 13 \quad-\quad 100$

Grasses

MARSh REEd GRASS

(Calamagrostis canadensis)47

\section{ENVIRONMENTAL VARIABLES}

MOISTURE REGIME: SUBHYGRIC TO HYGRIC

NUTRIENT REGIME: $\mathrm{RICH}$

ELEVATION: $758 \mathrm{M}$

Soll DRAINAGE: MODERATELY WELL

ECOLOGICAL STATUS SCORE: 18

\section{FORAGE PRODUCTION(KG/HA) n=1}

$\begin{array}{ll}\text { Grass } & 1292 \\ \text { ForBS } & 1440 \\ \text { Total } & 2732\end{array}$

ECOLOGICALLY SUSTAINABLE STOCKING RATE $2.02 \mathrm{ha} / \mathrm{AUM}(4.05-1.35)$ $0.2 \mathrm{AUM} / \mathrm{ac}(0.1-0.3)$ 


\section{CMC16. Aspen/ Smooth brome (Populus tremuloides/Bromus inermis)}

$\mathbf{n = 1}$ This community type is similar to the previously described red osier dogwood dominated community type, but has a high cover of smooth brome in the understory. Smooth brome is an introduced grass that can increase with increased grazing pressure, but smooth brome is also highly invasive and can invade into ungrazed areas. The invasion of non-native invaders onto the site makes this community moderately productive for domestic livestock.

\section{Plant Composition Canopy Cover(\%)} MEAN RANGe CONST.

\section{Trees}

TREMBLING ASPEN

(Populus tremuloide

\section{SHRUBS}

PRICKLY Rose

(Rosa acicularis)

SNOWBERRY

(Symphoricarpos

occidentalis)

RED OSIER DOGWOOD

(Cornus stolonifera)

FORBS

TALL LUNGWORT

(Mertensia paniculata)

VEINY MEADOW RUE

(Thalictrum venulosum)

Creamy Peavine

(Lathyrus ochroleucus)

80

100

3

3

1

100

100

100

\section{Grasses}

SMOOTH BROME

(Bromus inermis)

MARSH REED GRASS

(Calamagrostis canadensis) 3

100

\section{ENVIRONMENTAL VARIABLES}

Moisture Regime: MESIC-SUBHYGRIC

NUTRIENT REGIME: MEDIUM TO RICH

ELEVATION: $600 \mathrm{M}$

SOIL DRAINAGE: MODERATELY WELL

ECOLOGICAL STATUS SCORE: 0 or MODIFIED

\section{FORAGE PRODUCTION(KG/HA)}

TOTAL:

$1100 *$ ESTIMATE

ECOLOGICALLY SUSTAINABLE STOCKING RATE 4.05 ha/AUM (4.05 - 2.02)

$0.1 \mathrm{AUM} / \mathrm{ac}(0.1-0.2)$ 


\section{CMC17. Aspen/Thimbleberry \\ (Populus tremuloides/Rubus parviflora)}

$\mathbf{n = 3}$ This community type was described on an east facing slope overlooking the Smoky River south of Grande Prairie. This community type is generally rare within the Central Mixedwood Subregion, and is more commonly found within the Montane Subregion south of the Crowsnest Pass. This community type is found on nutrient rich seepage areas. Forage production of this type can be quite high because of the favourable moisture and nutrient conditions. However, Thimbleberry is generally unpalatable to livestock and useable forage production is quite low due to the predominance of thimbleberry and is generally considered to be non-use for domestic livestock.

\section{Plant Composition Canopy Cover(\%) \\ Mean Range Const.}

TREES

TREMBLing ASPEN

(Populus tremuloides)

BALSAM POPLAR

(Populus balsamifera)

SHRUBS

THIMBLEBERRY

(Rubus parviflorus)

PRICKLY ROSE

(Rosa acicularis)

LOW BUSH CRANBERRY

(Viburnum edule)

\section{FORBS}

WILD SARSAPARILLA

(Aralia nudicaulis)

BUNCHBERRY

(Cornus canadensis)

Creamy Peavine

(Lathyrus ochroleucus)

LILY-OF-THE-VALLEY

(Maianthemum canadense) $2 \quad 1-2 \quad 100$

DEWBERRY

(Rubus pubescens)

Grasses

MOUNTAIN RICE GRass

(Oryzopsis asperifolia)

MARSH REED GRASS

(Calamagrostis canadensis) 5
$1-2 \quad 100$

$\begin{array}{lll}31 & 23-45 & 100 \\ 4 & 0-7 & 67\end{array}$

$44 \quad 18-85 \quad 100$

$\begin{array}{lll}7 & 4-9 & 100\end{array}$

$4 \quad 1-7 \quad 100$

$4 \quad 2-5 \quad 100$

$6 \quad 4-6 \quad 100$

$1-2 \quad 100$

$1-2$

$1-13 \quad 100$

$1-6 \quad 100$

\section{ENVIRONMENTAL VARIABLES}

MOISTURE REgIME: SUBHYGRIC

Nutrient REgime: RicH

EleVATION: $650-698(675) \mathrm{M}$

SoIL Drainage:

WELL - MODERATELY WELL

ECOLOGICAL STATUS SCORE: 18

FORAGE PRODUCTION(KG/HA) n=3

GRASS 71(0-214)

FORBS 195(74-326)

SHRUBS 469(204-988)

TотAL 735(288-1172)

ECOLOGICALLY SUSTAINABLE STOCKING RATE

$2.5 \mathrm{ha} / \mathrm{AUM}(6.7-1.62)$

$0.16 \mathrm{AUM} / \mathrm{ac}(0.06-0.25)$ 


\section{CENTRAL MIXEDWOOD SUBREGION}

\section{CONIFEROUS AND MIXEDWOOD FOREST COMMUNITIES}

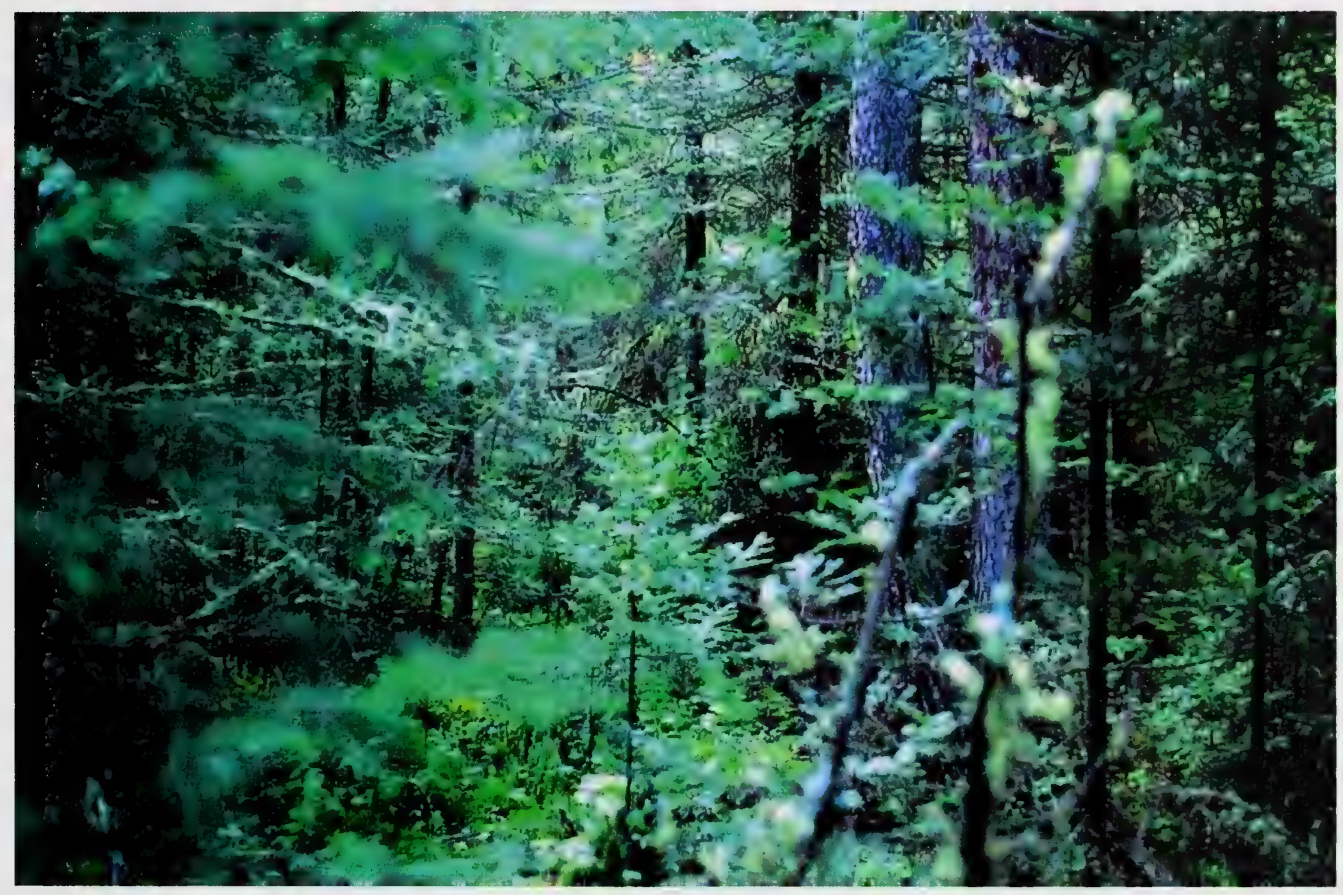

Photo 10. The Balsam fir-White spruce/Moss community type is the climatic climax community for the Central Mixedwood subregion. 


\section{CONIFEROUS AND MIXEDWOOD FORESTS}

The mixedwood and coniferous community types described in this guide represent five ecological sites as described by Beckingham and Archibald (1996). On sites with subxeric moisture and poor nutrient regimes, coarse textured, sandy soils open stands of jack pine generally dominate $(\mathrm{Pj} / \mathrm{Alder}, \mathrm{Pj} /$ Bearberry). These community types commonly have a carpet of lichens covering the forest floor and a thin organic layer typically less than $5 \mathrm{~cm}$ thick (Beckingham and Archibald 1996).

On slightly moister sites with submesic moisture and medium nutrient regimes aspen grows in conjunction with jack pine to form the Aw-Pj/Bearberry/Lichen community type. The soils of this community type continue to be coarse-textured but the moisture and nutrient conditions are more favourable to the growth of aspen.

The mesic/medium sites are generally dominated by white spruce (Balsam fir-Sw/Moss, Sw/Moss, Sw/Creeping red fescue) and mixedwood communities of aspen and spruce (Aw$\mathrm{Sw} / \mathrm{Rose} / \mathrm{Low}$ forb). These communities represent the reference ecosite for the Boreal Mixedwood subregion (Beckingham and Archibald 1996). Generally, these sites have moderately fine to fine-textured till or glaciolacustrine parent materials. Pioneer deciduous species (aspen, balsam poplar and birch) are replaced with white spruce and balsam fir as these sites develop successionally. With succession shade tolerant plants take over the herbaceous layer as conifers dominate the canopy. These shade tolerant species are unproductive and often unpalatable for domestic livestock. Forage productivity declines from 2.0 ha/AUM in a deciduous community to $4.0-8.1 \mathrm{ha} / \mathrm{AUM}$ in a mixedwood community to less than $40 \mathrm{ha} / \mathrm{AUM}$ in a conifer community.

Black spruce and larch communities generally dominate on wetter sites with subhygric to subhydric moisture regimes and poor to medium nutrient regimes to form the $\mathrm{Sb} / \mathrm{Bog}$ birch and $\mathrm{Sb} /$ Labrador tea/Moss community types. Larch is more tolerant of excessive moisture and is indicative of an enriched nutrient status, while black spruce is typical in areas of stagnating ground water with poor nutrient status (Hay et al. 1985). Generally, these community types are considered non-use for domestic livestock.

Beckingham and Archibald (1996), provide a good description on how the conifer and mixedwood communities are arranged in the landscape. 


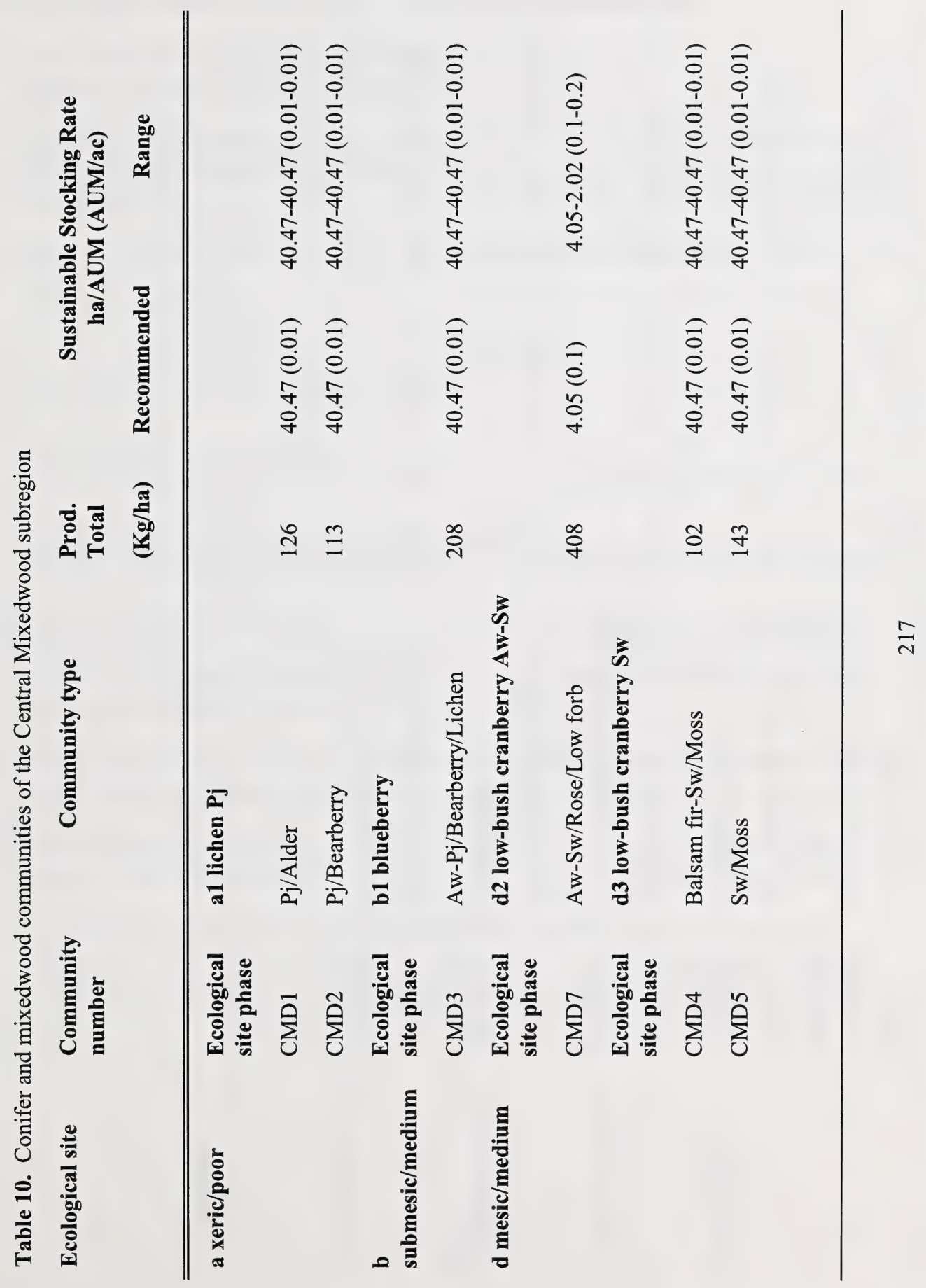




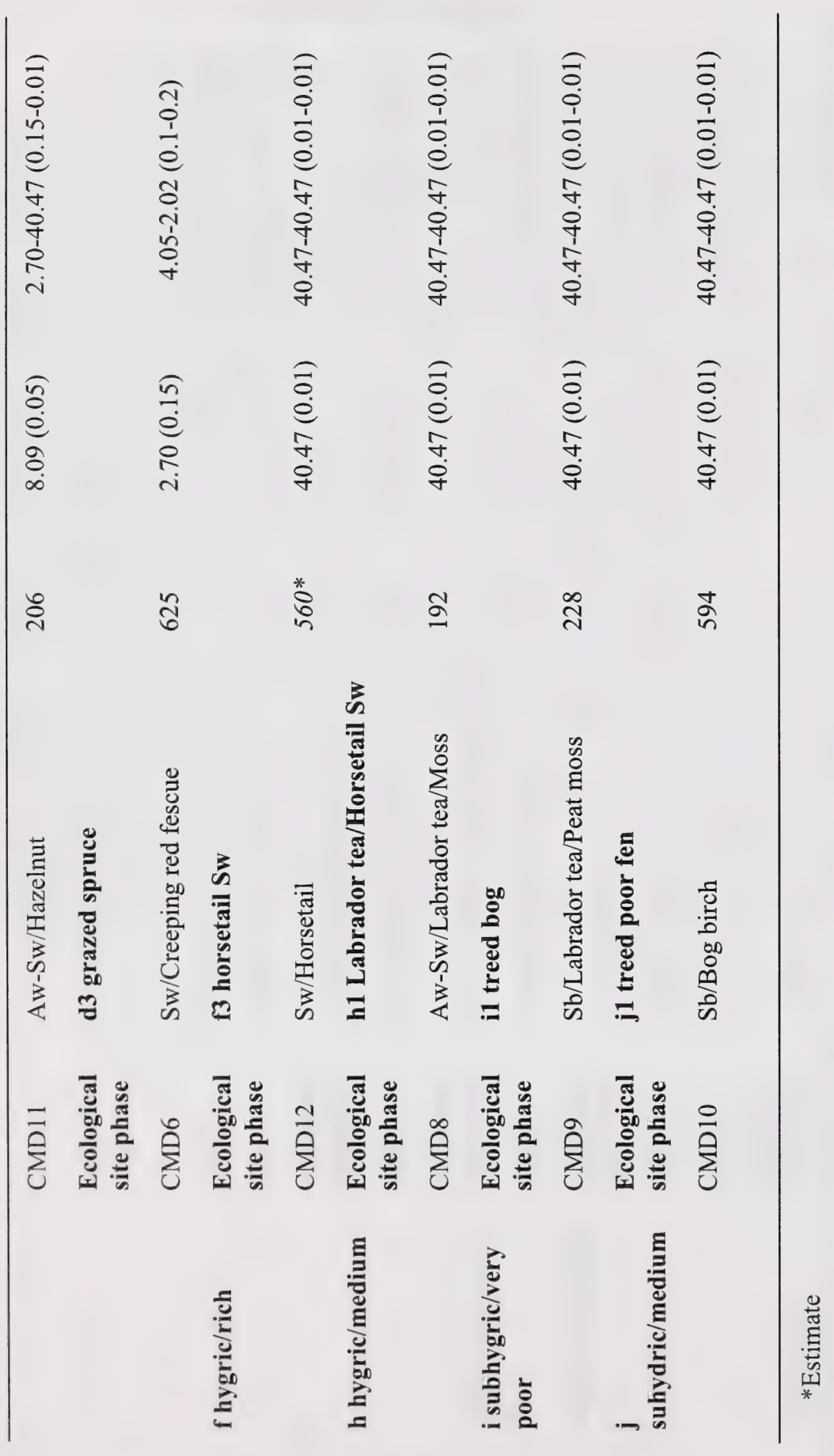

$\frac{\infty}{N}$ 


\section{Key to Conifer and Mixedwood Types - Central Mixedwood Subregion}

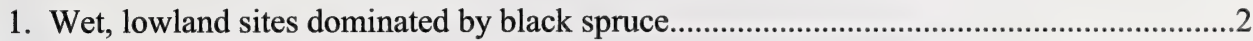

Upland mesic sites or well drained sandy sites............................................................

2. Bog birch, sedge dominate understory (rich fen).........................Sb/Bog Birch (CMD10) Labrador tea dominates understory, larch present (poor fen) Sb/Labrador Tea/Peat Moss (CMD9)

3. Mesic sites dominated by spruce, aspen, balsam poplar (maybe co-dominated by jack pine)

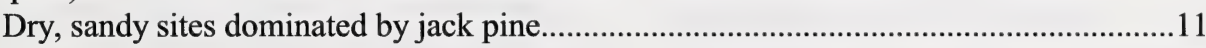

4. Mixedwood types, mixture of conifer and deciduous trees...........................................5

White spruce or balsam fir dominated types..............................................................

5. Aw-Sw mixedwood, typical mesic sites

Drier sites with Jack pine, Aw-Pj dominated.

Aw-Pj/Bearberry/Lichen (CMD3)

6. Rose, low forb, hazelnut dominated, typical mesic sites

7. Rose, low forb dominated. .Aw-Sw/Rose/Low Forb (CMD7)

Hazelnut dominated .Aw-Sw/Hazelnut (CMD11)

8. Balsam fir dominates(old growth forest). Balsam Fir-Sw/Moss (CMD4)

White spruce dominates overstory.

9. Spruce with agronomic species in the understory .Sw/Creeping Red Fescue (CMD6) Spruce with native species in the understory. 10

10. Moss dominates understory. Sw/Moss (CMD5) Horsetail dominates understory. .Sw/Horsetail(CMD12)

11. Jack pine overstory, bearberry or lichen dominates understory, alder low in cover or absent. .Pj/Bearberry (CMD2) Jack pine overstory, alder dominates understory. Pj/Alder (CMD1) 


\section{CMD1. Pj/Alder \\ (Pinus banksianal Alnus crispa)}

$\mathbf{n = 1}$ This community type is found on dry, rapidly drained, sandy soils with a poor nutrient status. Consequently, production is quite low. Cattle will utilize these areas due to the easy access, however overutilization will quickly deplete the area of forage. This community type would be rated as secondary or non-use range.

\section{Plant Composition Canopy Cover(\%) MEAN RANGE CONST.}

TREES

JACK PINE

(Pinus banksiana) $\quad 45 \quad-\quad 100$

SHRUBS

GREEN ALDER

(Alnus crispa)

PRICKLY ROSE

(Rosa acicularis) $\quad 5 \quad-\quad 100$

BLUEBERRY

(Vaccinium myrtilloides) $13 \quad-\quad 100$

FORBS

TWIN-FLOWER

(Linnaea borealis)

BEARBERRY

(Arctostaphylos uva-ursi) T $\quad$ - $\quad 100$

WILD SARSAPARILLA

(Aralia nudicaulis)

3

WILD LILY-OF-THE-VALLEY

(Maianthemum canadense) 4

GRASSES

SEDGES

(Carex spp.)

HAIRY WILD RYE

(Elymus innovatus)

NORTHERN RICEGRASS

(Oryzopsis pungens)

\section{ENVIRONMENTAL VARIABLES}

MOISTURE REGIME: SUBXERIC

NUTRIENT REgIME POOR

ELEVATION: $606 \mathrm{M}$

SOIL DRAINAGE: RAPIDLY

Percent Slope Gradient:

$$
\text { 2- } 8
$$

ECOLOGICAL STATUS SCORE: 18

\section{Forage Production (KG/HA) $n=1$}

$\begin{array}{ll}\text { GRASS } & 0 \\ \text { FORBS } & 40 \\ \text { SHRUBS } & 86 \\ \text { TOTAL } & 126\end{array}$

ECOLOGICALLY SUSTAINABLE STOCKING RATE GENERALLY NON-USE $40.47 \mathrm{ha} / \mathrm{AUM}(40.47$ - 40.47) $0.01 \mathrm{AUM} / \mathrm{ac}(0.01-0.01)$ 


\section{CMD2. Pj/Bearberry \\ (Pinus banksiana/Arctostaphylos uva-ursi)}

$\mathbf{n = 2}$ This community represents a jack pine forest which is very similar to the $\mathrm{Pj} / \mathrm{Alder}$ community type. Like the previous community cattle will utilize these areas due to the easy access, however overutilization will quickly deplete the forage supply. This community type would be rated as secondary range and should be grazed on a single rotation per year.

\section{Plant Composition Canopy Cover(\%) MEAN RANGE CONST.}

\section{Trees}

JACK PINE

(Pinus banksiana)

TREMBLING ASPEN

(Populus tremuloides)

\section{SHRUBS}

BOG CRANBERRY

(Vaccinium vitis-idaea)

PRICKLY ROSE

(Rosa acicularis)

BLUEBERRY

(Vaccinium myrtilloides)

\section{ForbS}

BEARBERRY

(Arctostaphylos uva-ursi) $\quad 18 \quad 16-19 \quad 100$

NORTHERN BEDSTRAW

(Galium boreale)

(Maianthemum canadense)

Philadelphia Fleabane

(Erigeron philadelphicus)

\section{Grasses}

HAIRY WILD RYE

(Elymus innovatus)

SEDGE SPP.

Carex spp.)

NORTHERN RICEGRASS

(Oryzopsis pungens)

Mosses

MosS SPP.
T

$38 \quad 30-45$

100

$0-1$

$0-11 \quad 50$

$0-1 \quad 50$

$0-3 \quad 50$

0-1 $\quad 50$

$0-1 \quad 100$

$0-1 \quad 50$

$2 \quad 0-3 \quad 50$

$6 \quad 0-11 \quad 100$

$2 \quad 1-2 \quad 100$

$18 \quad 0-35 \quad 100$

\section{ENVIRONMENTAL VARIABLES}

MoISTURE REGIME:

SUBMESIC

NUTRIENT REgIME:

SUBMESOTROPHIC

Elevation:

576-671 (624) M

SoIl DRAINAGE:

RAPIDLY

PERCENT SLOPE GRAdient: $10 \%$

ECOLOGICAL STATUS SCORE: 18

Forage Production (KG/HA) $n=2$

$\begin{array}{ll}\text { GRASS } & 25(0-50) \\ \text { FORBS } & 47(40-54) \\ \text { SHRUBS } & 41(10-72) \\ \text { TOTAL } & 113(100-126)\end{array}$

ECOLOGICALLY SUSTAINABLE STOCKING RATE GENERALLY NON-USE $40.47 \mathrm{ha} / \mathrm{AUM}(40.47-40.47)$ $0.01 \mathrm{AUM} / \mathrm{ac}(0.01-0.01)$ 


\section{CMD3. Aw-Pj/Bearberry/Lichen \\ (Populus tremuloides-Pinus banksiana/Arctostaphylos uva-ursi/Lichen)}

$\mathbf{n = 2}$ This community type represents a aspen forest with a secondary canopy of jack pine. It is very similar to the $\mathrm{Pj} / \mathrm{Bearberry}$ community type, but it is found on slightly moister soils with better nutrients. These conditions favour the growth of aspen. Like the previous community cattle will utilize these areas due to the easy access, however overutilization will quickly deplete the forage supply. This community type would be rated as secondary range and should be grazed on a single rotation per year.

\section{Plant Composition Canopy Cover(\%) MEAN RANGE CONST.}

TREES

JACK PINE

(Pinus banksiana)

TREMBLING ASPEN

(Populus tremuloides)

SHRUBS

BOG CRANBERRY

(Vaccinium vitis-idaea)

PRICKLY ROSE

(Rosa acicularis)

BLUEBERRY

(Vaccinium myrtilloides)

FORBS

BEARBERRY

(Arctostaphylos uva-ursi) 8

TWINFLOWER

(Linnaea borealis) $\quad \mathrm{T}$

WILD LILY-OF-THE-VALLEY

(Maianthemum canadense) 2

TOADFLAX

(Comandra umbellata) 1

Grasses

SLENDER WHEAT GRASS

(Agropyron trachycaulum)

NORTHERN RICEGRASS

(Oryzopsis pungens)

SEDGE

(Carex spp.)

LICHENS
15

$10-20$

100

20

$15-25 \quad 100$

$0-8 \quad 50$

$1 \quad 0-1 \quad 50$

$8 \quad 0-15 \quad 50$

$2-12 \quad 100$

$0-1 \quad 50$

$0-3 \quad 50$

0-1 $\quad 100$

$0-4 \quad 50$

$-4 \quad 50$

$0-7 \quad 100$

16-81 100

\section{ENVIRONMENTAL VARIABLES}

MOISTURE REgIME:

SUBMESIC

NUTRIENT REgIME:

SUBMESOTROPHIC

EleVATION:

$576 \mathrm{M}$

SOIL DRAINAGE:

WELL

ECOLOGICAL STATUS SCORE: 18

Forage Production (KG/Ha) $\mathrm{n}=2$

$\begin{array}{ll}\text { GRASS } & 28 \\ \text { FORBS } & 46 \\ \text { SHRUBS } & 134 \\ \text { TOTAL } & 208\end{array}$

ECOLOGICALLY SUSTAINABLE STOCKING RATE

GENERALLY NON-USE

$40.47 \mathrm{ha} / \mathrm{AUM}$ (40.47 - 40.47)

$0.01 \mathrm{AUM} / \mathrm{ac}(0.01-0.01)$ 


\section{CMD4. Balsam fir-Sw/Moss \\ (Abies balsamea-Picea glauca/Moss)}

$\mathbf{n = 1}$ This is a mature balsam fir forest which represents the climax vegetation for the area. The northerly aspect of this community type has probably protected the site from past disturbance by fires and allowed the community to undergo succession. The high canopy of balsam fir and spruce limits the light reaching the forest floor, limiting the growth of grasses and forbs. As a result, the forage productivity of this community type is very low. This community would be considered non-use.

\section{Plant Composition Canopy Cover(\%)}

MEAN RANGE CONST.

\section{Trees}

WhITE SPRUCE

(Picea glauca)

BALSAM FIR

(Abies balsamea)

SHRUBS

PRICKLY ROSE

(Rosa acicularis)

FORBS

BUNCHBERRY

(Cornus canadensis)

TWINFLOWER

\section{(Linnaea borealis)}

WOODLAND HORSETAIL

(Equisetum sylvaticum)

RUNNING CLUBMoss

(Lycopodium clavatum)

Mosses

FEATHER MOSS

(Pleurozium schreberi)

STAIRSTEP MOSS

(Hylocomium splendens)

$\begin{array}{lll}25 & - & 100 \\ 40 & - & 100 \\ T & - & 100 \\ 10 & - & 100 \\ 4 & - & 100 \\ 6 & - & 100 \\ 3 & - & 100 \\ & & \\ 51 & - & 100 \\ 37 & - & 100\end{array}$

\section{ENVIRONMENTAL VARIABLES}

MoISTURE Regime:

$$
\text { MESIC }
$$

NUTRIENT REgIME: MESOTROPHIC

ELEVATION:

$$
333 \mathrm{M}
$$

SoIL DRAINAGE:

WELL

Percent Slope Gradient:

$$
5 \%
$$

ASPECT:

NORTHERLY

ECOLOGICAL STATUS SCORE: 18

Forage Production (KG/Ha) $n=1$

$\begin{array}{ll}\text { GRASS } & 0 \\ \text { FORBS } & 102 \\ \text { SHRUBS } & 0 \\ \text { TOTAL } & 102\end{array}$

ECOLOGICALLY SUSTAINABLE STOCKING RATE

GENERALLY NON-USE

$40.47 \mathrm{ha} / \mathrm{AUM}(40.47$ - 40.47)

$0.01 \mathrm{AUM} / \mathrm{ac}(0.01-0.01)$ 


\section{CMD5. Sw/Moss \\ (Picea glauca/Moss)}

$\mathbf{n}=7 \quad$ This community is considered successionally mature. A more continuous cover of feather moss and presence of balsam fir would bring this community type closer to the climax community described previously. The limited light penetration in this community discourages understory development, making this a non-use area for domestic livestock.

\section{Plant Composition Canopy Cover(\%)} MEAN RANGE CONST.

\section{TREES}

White SPRuce

(Picea glauca)

TREMBLING ASPEN

(Populus tremuloides)

Shrubs

PRICKLY ROSE

(Rosa acicularis)

RED OSIER DOGWOOD

(Cornus stolonifera)

LOW BUSH CRANBERRY

(Viburnum edule)

\section{FORBS}

BUNCHBERRY

(Cornus canadensis)

FIELD HORSET AIL

(Equisetum arvense)

TWINFLOWER

(Linnaea borealis)

Palmate LEAVEd COLTSFOOT

(Petasites palmatus) 3

DEWBERRY

(Rubus pubescens) $\quad 1 \quad 0-3 \quad 57$

FIREWEED

(Epilobium angustifolium) $1 \quad 0-3 \quad 29$

Grasses

MARSH REED GRASS

(Calamagrostis canadensis) 1

Moss

STAIR STEP MOSS

(Hylocomium splendens) $13 \quad 0-49 \quad 19$

FEATHERMOSS

$\begin{array}{llll}\text { (Pleurozium schreberi) } & 1 & 0-7 & 17\end{array}$

\section{ENVIRONMENTAL VARIABLES}

MOISTURE REGIME: MESIC

Nutrient Regime: MESOTROPHIC

ELEVATION: $150-606(415) \mathrm{M}$

SOIL DRAINAGE: WELL

Percent Slope Gradient: $1 \%$

ECOLOGICAL STATUS SCORE: 18

\section{Forage Production(Kg/HA) $n=6$}

$\begin{array}{ll}\text { GRASS } & 10(0-40) \\ \text { FORBS } & 78(0-172) \\ \text { SHRUBS } & 54(0-158) \\ \text { TOTAL } & 143(36-370)\end{array}$

\section{ECOLOGICALLY SUSTAINABLE STOCKING RATE} GENERALLY NON-USE $40.47 \mathrm{ha} / \mathrm{AUM}(40.47$ - 40.47) $0.01 \mathrm{AUM} / \mathrm{ac}(0.01-0.01)$ 


\section{CMD6. Sw/Creeping red fescue \\ (Picea glauca/Festuca rubra)}

$\mathbf{n = 1}$ This community type represents an old cultivated field which has been planted to white spruce. The canopy of spruce is beginning to shade the understory causing a decline in productivity, however, there is still enough forage for grazing between the spruce trees.

\section{Plant Composition Canopy Cover(\%)}

MEAN RANGE CONST.

\section{TreEs}

Trembling Aspen

(Populus tremuloides)

White SPRUCE

(Picea glauca)

BALSAM POPLAR

(Populus balsamifera)

SHRUBS

SNOWBERRY

(Symphoricarpos

occidentalis)

PRICKLY Rose

(Rosa acicularis)

Forbs

STRAWBERRY

(Fragaria virginiana)

Clover

(Trifolum hybridum)

DANDELION

(Taraxacum officinale)

LINDLEY'S ASTER

(Aster ciliolatus)

Grasses

Creeping Red fescue

(Festuca rubra)

HAIRY WILD RYE

(Elymus innovatus)

SLENDER WHEAT GRASS

(Agropyron trachycaulum) 11

SEDGE

(Carex spp.)
100

100

100

$1 \quad-\quad 100$

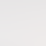

\section{ENVIRONMENTAL VARIABLES}

MoISTURE Regime:

$$
\text { Mesic }
$$

NUTRIENT REGIME: MESOTROPHIC

Elevation:

$606 \mathrm{M}$

SoIL DRAINAGE:

WELL

ECOLOGICAL STATUS SCORE: MODIFIED

\section{Forage Production (KG/Ha) $n=1$}

$\begin{array}{ll}\text { GRASS } & 525 \\ \text { FORBS } & 100 \\ \text { SHRUBS } & 0 \\ \text { TOTAL } & 625\end{array}$

ECOLOGICALLY SUSTAINABLE STOCKING RATE $2.70 \mathrm{ha} / \mathrm{AUM}(4.05-2.02)$

$0.15 \mathrm{AUM} / \mathrm{ac}(0.1-0.2)$ 


\section{CMD7. Aw-Sw/Rose/Low forb \\ (Populus tremuloides-Picea glauca/ Rosa acicularis/Low forb)}

$\mathbf{n}=\mathbf{8}$ This community type is dominated by aspen in the primary canopy and by spruce in the secondary canopy It occupies similar site conditions to the Aw/Rose/Low forb community type. As spruce succeeds into the canopy it reduces the amount of light reaching the forest floor reducing the growth of shrubs, forbs and grass. This community type would be rarely used by livestock and should be rated as secondary range.

Plant Composition Canopy Cover(\%) MEAN RANGE CONST.

TREES

White SPRUCE

(Picea glauca)

TREMbling Aspen

(Populus tremuloides)

BALSAM POPLAR

(Populus balsamifera)

SHRUBS

SNOWBERRY

(Symphoricarpos

occidentalis)

PRICKLY ROSE

(Rosa acicularis)

BRACTED HONEYSUCKLE

(Lonicera involcrata)

BUFFALOBERRY

(Shepherdia canadensis)

FORBS

TWINFLOWER

(Linnaea borealis)

BUNCHBERRY

(Cornus canadensis)

WINTERGREEN

(Pyrola asarifolia)

DEWBERRY

(Rubus pubscens)

BISHOP's CAP

(Mitella nuda)

Grasses

HAIRY WILD RYE

(Elymus innovatus)

MARSH REED GRASS

(Calamagrostis canadensis) 3

Mosses

MOSS SPP.

$\begin{array}{lll}33 & 9-80 & 100 \\ 32 & 20-60 & 100 \\ 2 & 0-10 & 29\end{array}$

$+2$

$\begin{array}{lll}1 & 0-4 & 29 \\ 12 & 1-19 & 100\end{array}$

$3 \quad 0-15 \quad 43$

$0-7 \quad 71$

$0-5 \quad 86$

$6 \quad 1-12 \quad 100$

$1 \quad 0-3 \quad 52$

$2 \quad 0-4 \quad 71$

$1 \quad 0-2 \quad 57$

$4 \quad 0-10 \quad 86$

$0-9 \quad 71$

4-7 $\quad 100$

\section{ENVIRONMENTAL VARIABLES}

Moisture Regime:

MESIC

NUTRIENT REGIME: MESOTROPHIC

ELEVATION: $150-853$ (635) M

SOIL DRAINAGE:

WELL

ECOLOGICAL STATUS SCORE: 18 - 12

Forage Production (KG/HA) $n=8$
GRASS
$128(2-308)$
FORBS
$190(70-418)$
SHRUBS
169(50-308)
TOTAL
$487(160-1034)$

ECOLOGICALLY SUSTAINABLE STOCKING RATE

$$
\begin{gathered}
4.05 \mathrm{ha} / \mathrm{AUM}(4.05-2.02) \\
0.1 \mathrm{AUM} / \mathrm{ac}(0.1-0.2)
\end{gathered}
$$




\section{CMD8. Aw-Sw/Labrador tea/Moss \\ (Populus tremuloides-Picea glauca/Ledum groenlandicum/Moss)}

$\mathbf{n = 1}$ This community type has relatively poor nutrient status. Labrador tea and bog cranberry are indicative of acidic soil surface soil conditions. Beckingham and Archibald (1996) described this ecosite with a jack pine and black spruce dominated overstory. The moisture and nutrient conditions of this community type are probably better than their ecosite, which allows aspen and white spruce to dominate the overstory, but the soil conditions are poorer than the Aw-Sw/Rose/Low forb community type. This community type produces little palatable forage and therefore would be classified as non-use.

\section{Plant Composition Canopy Cover(\%)}

MEAN RANGE CONST.

\section{TREES}

TREMbling ASPEN

(Populus tremuloides)

WHITE SPRUCE

(Picea glauca)

SHRUBS

LABRADOR TEA

(Ledum groenlandicum.)

BLUEBERRY

(Vaccinium myrtilloides)

BOG CRANBERRY

(Vaccinium vitis-idaea) $4 \quad-\quad 100$

FORBS

BUNCHBERRY

(Cornus canadensis)

TWINFLOWER

(Linnaea borealis)

BASTARD'S TOADFLAX

(Geocaulon lividum)

COW-WHEAT

(Melampyrum lineare)

GRASSES

HAIRY WILD RYE

(Elymus innovatus)

Mosses

Moss spp.

$\begin{array}{lll}55 & - & 100 \\ 40 & - & 100 \\ 11 & - & 100 \\ 8 & - & 100 \\ 4 & - & 100 \\ 5 & - & 100 \\ 5 & - & 100 \\ 3 & - & 100 \\ 3 & - & 100 \\ 1 & - & 100 \\ 67 & - & 100\end{array}$

\section{ENVIRONMENTAL VARIABLES}

Moisture Regime:

SubMESIC-MESIC

NUTRIENT REGIME:

SUBMESOTROPHIC-MESOTROPHIC

ELEVATION:

$333 \mathrm{M}$

SoIl Drainage:

MOdERATELY WELL

ECOLOGICAL STATUS SCORE: 18

\section{Forage Production (KG/Ha) $n=1$}

$\begin{array}{ll}\text { GRASS } & 0 \\ \text { FORBS } & 96 \\ \text { SHRUBS } & 96 \\ \text { TOTAL } & 192\end{array}$

\section{ECOLOGICALLY SUSTAINABLE STOCKING RATE}

GENERALLY NON-USE

$40.47 \mathrm{ha} / \mathrm{AUM}(40.47-40.47)$

$0.01 \mathrm{AUM} / \mathrm{ac}(0.01-0.01)$ 


\section{CMD9. Sb/Labrador tea/Moss (Picea mariana/Ledum groenlandicum/Moss)}

$\mathbf{n = 8}$ This community type appears to be related to the bog ecosite described by Beckingham and Archibald (1996). The bog ecosite commonly has organic soils consisting of slowly decomposing peat moss. This community type is considered non-use for livestock, due to the lack of forage and poor accessibility.

\section{Plant Composition Canopy Cover(\%) MEAN RANGE CONST.}

\section{TREES}

LARCH

(Larix laricina)

BLACK SPRUCE

(Picea mariana)

SHRUBS

WILLOW SPP.

(Salix spp.)

LABRADOR TEA

(Ledum groenlandicum)

FORBS

Cloudberry

(Rubus chamaemorus)

HORSETAIL

(Equisetum arvense)

(Equisetum scirpoides)

Grasses

MARSH REED GRASS

(Calamagrostis canadensis) 3

SEdGe

(Carex aurea)

WATER SEDGE

(Carex aquatilis$$
14
$$

$$
\text { 10-75 }
$$

31

$5-65$

88

$\begin{array}{lll}5 & 1-20 \quad 38\end{array}$

$29 \quad 7-61 \quad 100$

8
$13-35 \quad 38$

$4 \quad 7-23 \quad 25$

$1 \quad 2-3 \quad 25$

\section{Mosses}

(Sphagnum spp)

\section{ENVIRONMENTAL VARIABLES}

MOISTURE REGIME: SUBHYDRIC

NUTRIENT REGIME:

OLIGOTROPHIC

ELEVATION: 579-636 (615) M

Soll Drainage: POORLY

ECOLOGICAL STATUS SCORE: 18

\section{Forage Production (KG/Ha) $n=8$}

$\begin{array}{ll}\text { GRASS } & 52(0-192) \\ \text { FORBS } & 61(0-286) \\ \text { SHRUBS } & 91(0-200) \\ \text { TOTAL } & 228(30-678)\end{array}$

ECOLOGICALLY SUSTAINABLE STOCKING RATE GENERALLY NON-USE $40.47 \mathrm{ha} / \mathrm{AUM}(40.47-40.47)$ $0.01 \mathrm{AUM} / \mathrm{ac}(0.01-0.01)$ 


\section{CMD10. Sb/Bog birch \\ (Picea mariana/Betula glandulosa)}

$\mathbf{n = 1}$ This community type is part ot the poor fen ecosite (Beckingham and Archibald 1996) because it has an intermediate nutrient regime between the bog and rich fen ecosites. Drainage on this community type is poor to very poor, but has some movement of water through the site. This community type has a well developed shrub layer and the grass layer consists mainly of marsh reed grass and sedge species. The productivity of this type is moderate, but the high water table limits access to domestic livestock. This community would be rated as non-use.

\section{Plant Composition Canopy Cover(\%) MEAN RANGE CONST.}

Trees

LARCH

(Larix laricina)

BLACK SPRUCE

(Picea mariana)

SHRUBS

WILlOW SPP.

(Salix spp.)

BOG BIRCH

(Betula glandulosa)

BLUEBERRY

(Vaccinium myrtilloides)

\section{FORBS}

SMALl BOG CRANBERRY

(Oxycoccus microcarpus)

HoRSETAIL

(Equisetum arvense) 2

THREE LEAVED Solomon's-SEAL

(Smilicina trifolia)

5

Grasses

MARSH REED GRASS

(Calamagrostis canadensis) 6

SEdge

(Carex aurea)

Mosses

(Sphagnum spp.)

100

100

100

100

100

\section{ENVIRONMENTAL VARIABLES}

Moisture Regime:

SUBHYDRIC

NUTRIENT REGIME:

OLIGOTROPHIC

ElEVATION:

$576 \mathrm{M}$

SoIl DRAINAGE:

POORLY

ECOLOGICAL STATUS SCORE: 18

Forage Production (KG/Ha) $n=1$

GRASS

104

FORBS $\quad 90$

SHRUBS $\quad 400$

TOTAL $\quad 594$
ECOLOGICALLY SUSTAINABLE STOCKING RATE

GENERALLY NON-USE

$40.47 \mathrm{ha} / \mathrm{AUM}(40.47-40.47)$

$0.01 \mathrm{AUM} / \mathrm{ac}(0.01-0.01)$ 


\section{CMD11. Sw/Beaked hazelnut/Moss (Picea glauca/Corylus cornuta/Moss)}

$\mathbf{n = 1}$ This is a mixedwood forest which is approaching climax. The northerly aspect of this community type has probably protected the site from past disturbance by fires and allowed the community to undergo succession. The high canopy of spruce limits the light reaching the forest floor, limiting the growth of grasses and forbs. As a result, the forage productivity of this community type is very low. This community would be considered non-use.

\section{Plant Composition Canopy Cover(\%)}

MEAN RANGE CONST.

TREeS

WHITE SPRUCE

(Picea glauca)

30

Trembling AsPen

(Populus tremuloides)

Shrubs

BeAKed Hazelnut

(Corylus cornuta)

RED OSIER DOGWOOD

(Cornus stolonifera)

PRICKLY ROSE

(Rosa acicularis)

FORBS

WILD SARSAPARILLA

(Aralia nudicaulis)

SHOWY ASTER

(Aster conspicuus)

TWINFLOWER

(Linnaea borealis)

BUNCHBERRY

(Cornus canadensis)

Mosses

Moss SPP.
40

30

10

10

3

3

3

73
100

100

100

100

100

100

100

100

100

100

\section{ENVIRONMENTAL VARIABLES}

Moisture Regime: MESIC

NUTRIENT REGIME: MESOTROPHIC

ELEVATION: $606 \mathrm{M}$

SoIL DRAINAGE: WELL

ECOLOGICAL STATUS SCORE: 18

\section{Forage Production(Kg/Ha)}

Total 206*Estimate

ECOLOGICALLY SUSTAINABLE STOCKING RATE 8.09 ha/AUM $(2.70-40.47)$ $0.05 \mathrm{AUM} / \mathrm{ac}(0.15-0.01)$ 


\section{CMD12. Sw/Horsetail \\ (Picea glauca/Equisetum arvense)}

$\mathbf{n = 1}$ This community type is wet and nutrient rich. These sites are commonly found on fluvial or glaciolacustrine parent materials where flooding or seepage enhances the substrate nutrient supply. With high water tables, wet soil conditions organic matter tends to accumulate which favours the growth of horsetails. Generally horsetails are unpalatable to livestock and the wet ground conditions limit access. Consequently, this community type should be rated as non-use.

\section{Plant Composition Canopy Cover(\%) MEAN RANGE CONST.}

\section{TREES}

White SPRUCE

(Picea glauca)

BALSAM FIR

(Abies balsamea)

SHRUBS

PRICKLY ROSE

(Rosa acicularis)

RIVER ALDER

(Alnus tenuifolia) 3

BRACTED HONEYSUCKLE

(Lonicera involucrata) 3

\section{FORBS}

DEWBERRY

(Rubus pubescens)

HORSETAIL

(Equisetum sylvaticum) 40

THREE LEAVED SOLOMONS SEAL

(Smilacina trifolia) 10

BUNCHBERRY

(Cornus canadensis)

3

Grasses

MARSH REED GRASS

(Calamagrostis canadensis) 10

100

100

100

100

\section{ENVIRONMENTAL VARIABLES}

MOISTURE REGIME: HYGRIC

Nutrient REgIME: PERMESOTROPHIC

ELEVATION: $600 \mathrm{M}$

SOIL DRAINAGE: POOR TO MODERATELY WELL

ECOLOGICAL STATUS SCORE: 18

Forage Production(KG/Ha)
ECOLOGICALLY SUSTAINABLE STOCKING RATE

GENERALLY NON-USE 40.47 ha/AUM (40.47 - 40.47) $0.01 \mathrm{AUM} / \mathrm{ac}(0.01-0.01)$ 


\section{CENTRAL MIXEDWOOD SUBREGION}

\section{FOREST CUTBLOCK COMMUNITIES}

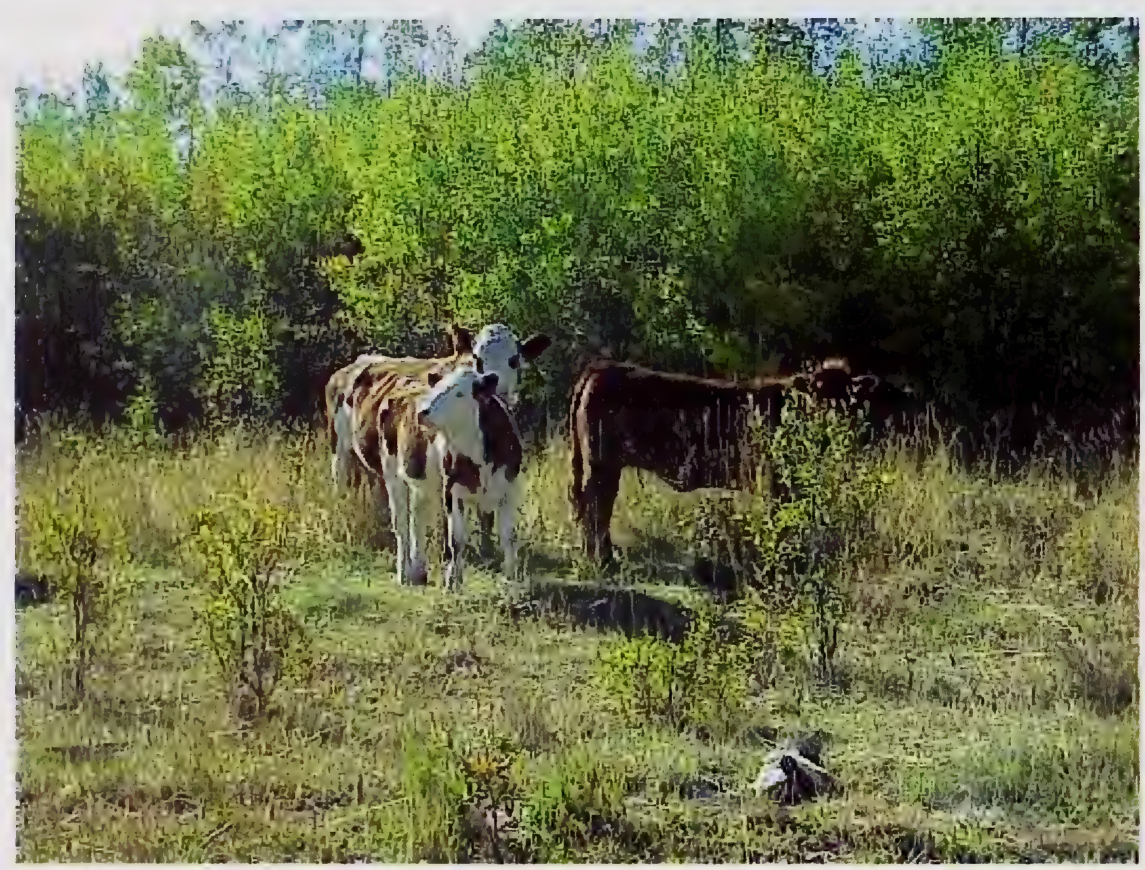

Photo 11. The Aspen/Rose/Marsh Reedgrass/Fireweed (CME1) community type develops after clear-cut logging of the modal Aspen/Rose/Tall Forb (CMC8) community. 


\section{FOREST CUTBLOCK COMMUNITIES}

Timber harvesting affects the understory community through removal of the tree layer (overstory) as well as through root destruction, soil compaction, scarification, forest floor displacement, and understory destruction. These mechanical disturbances can alter the energy flows between soil and plants which in turn, can alter the tree regeneration, species diversity and production. Logging (overstory removal) will often increase understory production by eliminating competition between overstory and understory species for light and nutrients. Any increases in production as a result of sustainable yield timber harvest are not included in the calculation of the overall carrying capacity of the disposition because these increases are only temporary and are not always available to livestock. To determine the rates (ha/AUM) for grazing on harvested cutblocks the carrying capacity is based on the undisturbed (prior to harvest) mature stand. For example, (CME1) Aspen/Rose/Marsh Reedgrass/Fireweed has an average production at 2-8 years following harvesting of $1838 \mathrm{~kg} / \mathrm{ha}$; however to ensure sustainable timber and forage production a conservative approach is taken by limiting the stocking rate to the pre-harvest plant community Aspen/Rose/Tall Forb (CMC8) average production of $978 \mathrm{~kg} / \mathrm{ha}$ or $2.0 \mathrm{ha} / \mathrm{AUM}(0.2 \mathrm{AUM} / \mathrm{ac})$.

Although sustained timber yield cutblocks can be productive primary range for both livestock and wildlife, careful management of these areas is required to ensure that both forest regeneration is successful and that livestock pre-harvest stocking levels are maintained. With good range management cutblocks can be grazed without negatively impacting regeneration however, in extreme circumstances, both livestock and wildlife grazing can affect regeneration success. In addition, timber harvesting has the potential to negatively impact range management success. It has been demonstrated in the Central Mixedwood that if given an alternative, livestock will avoid regenerating deciduous cutblocks, resulting in a net loss of available AUMs and an increase in grazing pressure on alternative plant community types. It is strongly recommended that these potential impacts are discussed by the stakeholders involved and a mitigative agreement reached prior to the integrated grazing and/or harvesting activity taking place. 


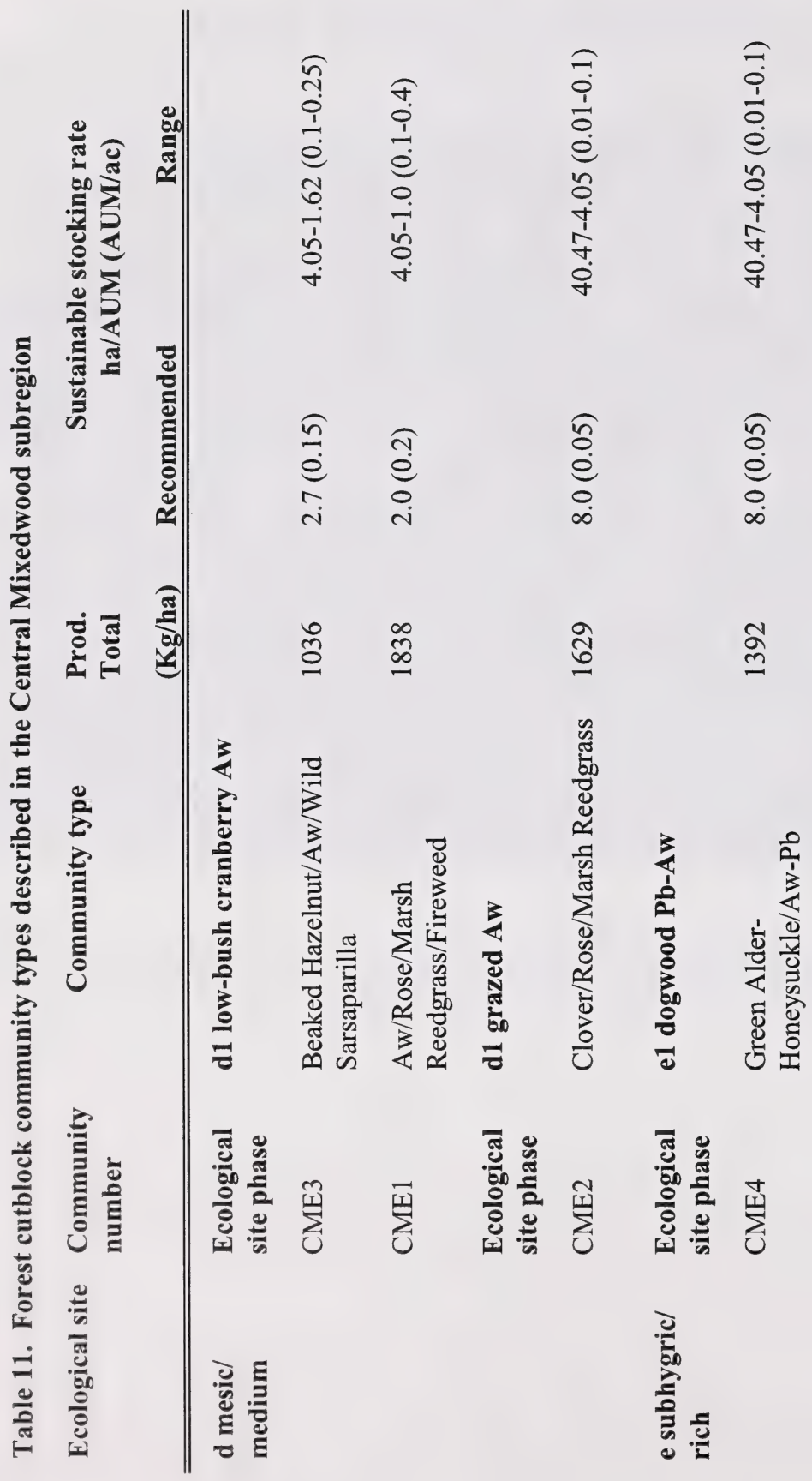

芩 
Key to Forest Cutblock Types - Central Mixedwood Subregion

1. Mesic sites dominated by Rose, Clover, Hazelnut or Marsh Reedgrass...............................2 Very moist, nutrient rich sites dominated by Alder and Honeysuckle.

Green Alder-Honeysuckle/Aw-Pb (CME4)

2. Rose, Fireweed, Marsh Reedgrass and/or Clover dominate the site 3 Hazelnut is dominant or co-dominant in the shrub layer.

Beaked Hazelnut/Aw/Wild Sarsaparilla (CME3)

3. Moderately grazed or ungrazed sites dominated by Rose and Marsh Reedgrass.

Aw/Rose/Marsh Reedgrass/Fireweed (CME1)

Heavily grazed sites dominated by Clover and Dandelion

.Clover/Rose/Marsh Reedgrass (CME2) 


\section{CME1. Aspen/Rose/Marsh Reedgrass/Fireweed \\ (Populus tremuloides/Rosa acicularis/Calamagrostis canadensis/Epilobium angustifolium)}

$\mathbf{n = 4}$ This community type formed after clear-cut logging an Aspen/Rose dominated community type. The logging probably occurred two to eight years ago. After logging, more light reaches the understory and grasses and forbs are able to flourish. As the aspen reestablishes itself, it rapidly gains dominance on the site. As aspen forms and fills in an overstory canopy, marsh reed grass will decline and rose, along with other shrubs and forbs, will become more abundant. This community type provides fairly good grazing opportunities in its early stages, but gradually excludes grazing livestock as the aspen saplings grow taller and form barriers to livestock movement through the area. This community type is in good to excellent range condition.

\section{Plant Composition Canopy Cover(\%) MEAN RANGE CONST.}

TrEes

TREMBLING Aspen

(Populus tremuloides)

BALSAM POPLAR

(Populus balsamifera)

SHRUBS

PRICKLY ROSE

(Rosa acicularis)

LOW BUSH CRANBERRY

(Viburnum edule)

BRACTED HONEYSUCKLE

(Lonicera involucrata)

FORBS

FIREWEED

$\begin{array}{llll}\text { (Epilobium angustifolium) } & 5 & 3-7 & 100 \\ \text { DEWBERRY } & & & \end{array}$

(Rubus pubescens)

Creamy Peavine

(Lathyrus ochroleucus)
LINDLEY'S ASTER

(Aster ciliolatus)

WILD SARSAPARILLA

(Aralia nudicaulis)

WILD STRAWBERRY

(Fragaria virginiana)

NORTHERN BEDSTRAW

(Galium boreale)

Palmate-Leaved Coltsfoot

(Petasites palmatus) 4

BUNCHBERRY

(Cornus canadensis)

Grasses

MARSH REED GRASS

(Calamagrostis canadensis) 23
4-11 100

$0-10 \quad 25$

$7 \quad 1-11 \quad 100$

$4 \quad 0-9 \quad 75$

$2 \quad 0-7 \quad 50$

$4 \quad 1-6 \quad 100$

$3 \quad 0-4 \quad 75$

$3 \quad 0-9 \quad 75$

$1 \quad 0-1 \quad 75$

$3 \quad 1-10 \quad 100$

$2 \quad 1-2 \quad 100$

$4 \quad 1-6 \quad 100$

$3 \quad-\quad 100$

$7-45 \quad 100$

\section{ENVIRONMENTAL VARIABLES}

Moisture Regime: MESIC

NUTRIENT REgIME: MEdiUM TO RICH

ELEVATION:

$$
758-914(821) \mathrm{M}
$$

SoIL DRAINAGE:

WELl TO MODERATELY WELL

ECOLOGICAL STATUS SCORE: 18

Forage Production(Kg/Ha) $n=4$

$\begin{array}{ll}\text { GRASS } & 714(150-1400) \\ \text { FORBS } & 824(158-1408) \\ \text { SHRUBS } & 300(92-698) \\ \text { TOTAL } & 1838\end{array}$

ECOLOGICALLY SUSTAINABLE STOCKING RATE $2.0 \mathrm{ha} / \mathrm{AUM}(4.05-1.0)$ $0.2 \mathrm{AUM} / \mathrm{ac}(0.1-0.4)$ 


\section{CME2. Clover/Rose/Marsh Reedgrass (Trifolium spp./Rosa acicularis/Calamagrostis canadensis)}

$\mathbf{n = 2}$ This community type describes the effects of moderate to heavy grazing of the CME1 Aw/marsh reed grass/rose/fireweed harvested community type. Low-growing forbs such as strawberry and clover indicate a moderate to heavy grazing regime for at least 2 to 3 growing seasons. With continued heavy grazing, succession will alter this community to a Kentucky bluegrass/clover-dandelion community. In order to sustain deciduous regeneration domestic grazing must be restricted to allow aspen and balsam suckers to emerge and proliferate.

\section{Plant Composition Canopy Cover(\%)

MEAN RANGE CONST.

\section{TREES}

Trembling Aspen

(Populus tremuloides)

SHRUBS

PRICKLY ROSE

(Rosa acicularis)

WILLOW

(Salix spp.)

Forbs

WHITE ClOVER

(Trifolium repens)

DANDELION

(Taraxacum officinale) $\quad 10 \quad 1-19 \quad 100$

FIREWEED

(Epilobium angustifolium) 5

DEWBERRY

(Rubus pubescens)
LINDLEY'S ASTER

(Aster ciliolatus)

STRAWBERRY

(Fragaria virginiana)

Grasses

MARSH REED GRASS

(Calamagrostis canadensis) 3

KentuCKy Bluegrass

(Poa pratensis)

$5 \quad 0-10 \quad 50$

Creeping Red Fescue

(Festuca rubra)

SEDGES

(Carex spp.)

$\begin{array}{lll}1 & 0-1 & 50 \\ 5 & 0-9 & 50\end{array}$

$13 \quad 2-24 \quad 100$

$10-19-100$

$2 \quad 0-3 \quad 50$

$1 \quad 0-2 \quad 50$

$1 \quad 0-2 \quad 50$

5

3

$0-10 \quad 50$

$0-6 \quad 50$

$6 \quad 1-9 \quad 100$

$0-10 \quad 50$

$1-5 \quad 100$

\section{ENVIRONMENTAL VARIABLES}

MoIsture Regime: MesiC

NUTRIENT REGIME: MEDIUM

ELEVATION: $606-914(760) \mathrm{M}$

SoIL DRAINAGE: WELl DRAINED

ECOLOGICAL STATUS SCORE: 6

Forage Production(KG/Ha) $n=2$

$\begin{array}{ll}\text { GRASS } & 723(290-1156) \\ \text { FORBS } & 461(84-838) \\ \text { SHRUBS } & 445(52-838) \\ \text { TOTAL } & 1629\end{array}$

ECOLOGICALLY SUSTAINABLE STOCKING RATE $8.0 \mathrm{ha} / \mathrm{AUM}(40.0-4.0)$ $0.05 \mathrm{AUM} / \mathrm{ac}(0.01-0.1)$ 


\section{CME3. Beaked Hazelnut/Aspen/Wild Sarsaparilla (Corylus cornuta/Populus tremuloides/Aralia nudicaulis)}

$\mathbf{n = 1}$ This community type formed after clear-cutting an Aw/hazelnut/wild forest community type similar to a CMC3 or DMC4. The presence of beaked hazelnut appears to be indicative of warmer sites that may have some fire history (Downing and Karpuk 1992). The opening of the canopy after logging seems to have allowed hazelnut to proliferate, possibly due to the increased light penetration and thus an increase in temperature. As aspen continues to mature, hazelnut may decline. Sites with high cover of hazelnut and/or thick aspen regeneration can have both limited access and forage availability for domestic livestock.

\section{Plant Composition Canopy Cover(\%) MEAN RANGE CONST.}

Trees

TREMBLING AsPen

(Populus tremuloides)

SHRUBS

BEAKed Hazelnut

(Corylus cornuta)

PRICKLY ROSE

(Rosa acicularis)

BUFFalOBERRY

(Shepherdia canadensis)

SASKATOON

(Amelanchier alnifolia)

WESTERN SNOWBERRY

(Symphoricarpos

occidentalis)

FORBS

DEWBERRY

(Rubus pubescens)

WILD SARSAPARILLA

(Aralia nudicaulis)

TALL LUNGWORT

(Mertensia paniculata)

STRAWBERRY

(Fragaria virginiana)

Palmate-leaved Coltsfoot

(Petasites palmatus)

GRASSES

MARSH REED GRASS

(Calamagrostis canadensis) 3

FRINGED BROME

(Bromus ciliatus)

HAIRY WILD RYE

(Elymus innovatus)
28

100

100

22

24

11

8

4

\section{5}

4

1

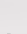

3

3

100

100

100

100

100

100

100

100

100

100

100

100

\section{ENVIRONMENTAL VARIABLES}

MoISTURE Regime:

$$
\text { MesiC }
$$

NUTRIENT REgIME:

MEDIUM

ELEVATION:

$686 \mathrm{M}$

Soll Drainage:

WELL DRAINED

ECOLOGICAL STATUS SCORE: 18

\section{Forage Production(KG/Ha) $n=1$}

$\begin{array}{ll}\text { GRASS } & 742 \\ \text { FORBS } & 190 \\ \text { SHRUBS } & 104 \\ \text { TOTAL } & 1036\end{array}$

ECOLOGICALLY SUSTAINABLE STOCKING RATE $2.0 \mathrm{ha} / \mathrm{AUM}(10.1-1.4)$

$0.2 \mathrm{AUM} / \mathrm{ac}(0.04-0.3)$ 


\section{CME4. Green Alder-Honeysuckle/Aspen-Balsam Poplar (Alnus crispa-Lonicera involucrata/Populus tremuloides-Populus balsamifera)}

$\mathbf{n = 1}$ This community type formed after clear-cut logging an Aw-Pb/green alder forest community type. This area is effected by a high (or perched) water table as indicated by the presence of balsam saplings and green alder The high water table in this community type may be partially caused by the clear-cutting. Clear-cutting deciduous stands causes the water table to rise because, even though the amount of water going into the site is the same, the amount of transpiration and water leaving the site is greatly reduced. This community type may provide good grazing opportunities as a mature stand; however the density of green alder and balsam poplar will restrict domestic access until natural thinning occurs in later seral stages.

\section{Plant Composition Canopy Cover(\%) MEAN RANGE CONST.}

Trees

TREMBLING ASPEN

(Populus tremuloides)

5

BALSAM POPLAR

(Populus balsamifera)

7

SHRUBS

GreEn Alder

(Alnus crispa)

BRACTED HONEYSUCKLE

(Lonicera involucrata)

PRICKLY ROSE

(Rosa acicularis)

LOW BUSH CRANBERRY

(Viburnum edule)

WILD RED RASPBERRY

(Rubus idaeus)

WESTERN SNOWBERRY

(Symphoricarpos

occidentalis)

FORBS

COW PARSNIP

(Heracleum lanatum)

COMMON HORSETAIL

(Equisetum arvense)

19

11

5

5

5

6

FIREWEED

(Epilobium angustifolium) 1

WILD SARSAPARILLA

(Aralia nudicaulis)

WILD VETCH

(Vicia americana)

Grasses

MARSH REED GRASS

(Calamagrostis canadensis) 39
100

100

100

100

\section{ENVIRONMENTAL VARIABLES}

Moisture Regime:

SUBHYGRIC

100

100

NUTRIENT REgime:

$\mathrm{RICH}$

ELEVATION:

$758 \mathrm{M}$

SoIl Drainage:

MODERATELY WELL

ECOLOGICAL STATUS SCORE: 18

Forage Production(KG/Ha) $n=1$

100

100

GRASS $\quad 384$

FORBS $\quad 808$

SHRUBS 200

TOTAL 1392

\section{ECOLOGICALLY SUSTAINABLE STOCKING RATE} $2.0 \mathrm{ha} / \mathrm{AUM}(13.5-1.0)$

$0.2 \mathrm{AUM} / \mathrm{ac}(0.03-0.4)$ 


\section{LITERATURE CITED}

Adams, B. 1981. Range ecology and the impact of livestock grazing on the Peace River Slopes, Alberta. Public Lands Division, Grazing Land Management, Range Management Unit. Peace River, Alta.

Adams, B.W., G. Ehlert, C. Stone, D. Lawrence, M. Alexander, M. Willoughby, C. Hincz, D. Moisey, and A.Bogen. 2003. Rangeland Health Assessment for Grassland, Forest and Tame Pasute. Alberta Sustainable Resource Development. Public Lands Division. Edmonton. AB. Pub. No. T/044. 104pp.

Alberta Rangeland Health Task Group. 1999. Terms of Reference. Alberta Agriculture Food and Rural Development (Public Lands Division), Alberta Environment (Forest Management Division). Edmonton, AB. 49pp.

Bailey, A.W., M.G. Willoughby, R. Johansen and S. Smith. Management of Yukon Rangelands. Renewable Resources, Yukon Territorial Government, Whitehorse, Yukon. 55pp. ISBN-155018-138-6.

Beckingham, J. 1993. Ecosystem associations of Northern Alberta. Dept. of Environmental Protection, Alberta Forest Service, Edmonton.

Beckingham, J. and J.H. Archibald. 1996. Field guide to ecosites of Northern Alberta. Special report 5. Canadian Forest Service. Northwest Region. Edmonton, Alta.

Brierly, D., D. Downing and D.O'Leary. 1985. An integrated resource inventory of the Keg River study area. Vol. 1 and 11, Vegetation Classification, Alberta Energy and Natural Resources. Edmonton, Alta.

Corns, I.G.W. and R.M. Annas. 1986. Field guide to forest ecosystems of West-Central Alberta. Northern Forestry Center, Canadian Forestry Service, Edmonton, Alta. 251pp.

Daubenmire, R. 1952. Forest vegetation of Northern Idaho and adjacent Washington and its bearing on concepts of vegetation classification. Ecol. Mongr. 22: 301-330.

Department of Environmental Protection. 1994. Natural Regions of Alberta. Alberta Environmental Protection. Edmonton, Alta. Pub. no.: I/531. 18pp.

Downing, D. and E. Karpuk. 1992. Aspen vegetation types of the Low Boreal Mixedwood ecoregion, East-Central Alberta. Alberta Forestry, Lands and Wildlife. Resource Information Branch. Land Information Services. Edmonton. AB. 79pp. 
Downing, D. 2000. Review of Forage Data Gaps: Native range community types, Central/Dry Mixedwood Natural Subregions, Lower Foothills Subregion. Forest Range Assessment Project. Alberta Agriculture Food and Rural Development, Public Lands Division. St.Paul. AB. 5pp.

Gauch, H.G. 1982. Multivariate analysis in community ecology. Cambridge University Press, Cambridge, 298pp.

Hay, W.K., J.M. Veltman and R.W. Haag. 1985. An integrated resource inventory of the East Beaver Lake Assessment Area, Physical Land and Forage Classifications. Vol. 1, Alberta Energy and Natural Resources, Resource Evaluation and Planning. Edmonton, Alta.

Holechek, J.L., R.D. Pieper and C.H.Herbel. 1995. Range management principles and practices. $2^{\text {ed }}$. Prentice-Hall Inc. Engewood Cliff. New Jersey. Chapter 8.

Invasive plants of natural habitats in Canada. 1992. Environmental Canada, Canadian Wildlife Service. Ottawa, Canada. $111 \mathrm{pp}$.

Johnson, D., L. Kershaw, A. MacKinnon and J. Pojar. 1995. Plants of the Western Boreal Forest and Aspen Parkland. Lone Pine Publishing. Edmonton. AB. 392pp.

Lane, C.T., M.G. Willoughby and M.J. Alexander. 2000. Range plant communities and carrying capacity for the Lower Foothills subregion. $3^{\text {rd }}$ approximation. Alberta Environment. Land and Forest Service. Edmonton. AB. Pub. No. T/532. 232pp.

Lodge, R.W., A. McLean and A. Johnston. 1968. Stock-poisoning plants of Western Canada. Agriculture Canada. Publication \# 1361. 35pp.

Mackinnon, A. J. Pojar, and R. Coupe. 1992. Plants of Northern British Columbia. Lone Pine Publishing, Edmonton, Alta. 345pp.

Mueggler, W.F. 1988. Aspen community types of the Intermountain Region. U.S.D.A. Intermoutain Research Station. INT-250. 133pp.

Peterson, E.B. and N. M. Peterson. 1992. Ecology, management and use of aspen and balsam poplar in the prairie provinces. Northern Forestry Center, Canadian Forest Service. Edmonton, AB. Special report $1.252 \mathrm{pp}$.

Range Survey Manual. 1992. Range Management Section, Alberta Forest Service. Edmonton, Alta. 39pp. 
Strong, W.L. and J.M. Thompson. 1995. Ecodistricts of Alberta: Summary of Biophysical Attributes. Alberta Environmental Protection, Resource Data Division. Edmonton, Alta. Pub. no. T/319. 91pp.

Strong, W.L. and K.R. Leggat. 1992. Ecoregions of Alberta. Alberta Forestry, Lands and Wildlife, Resource Information Branch, Edmonton, Alta. T/245. 77pp.

Strong, W.L.1992. Ecoregions and Ecodistricts of Alberta. Alberta, Forestry Lands and Wildlife. Land Information Services Division. Resource Information Branch. Edmonton, Alta. Pub. no. $\mathrm{T} / 244,77 \mathrm{pp}$.

Task Group on Unity and Concept. 1995. New concepts for assessment of rangeland condition. J. Range Manage. 38:220-225.

Thompson, W.H. and P.L. Hansen. 2002. Classification and management of riparian and wetland sites of the Alberta Grassland Natural Region and adjacent subregions. Bitterroot Restoration Inc. Prepared for the Alberta Riparian Habitat Management Program-Cows and Fish, Lethbridge, Alberta. 416pp.

Wilkinson, K. 1990. Trees and shrubs of Alberta. Lone Pine Publishing. Edmonton, Alta. 191pp.

Wilkinson, K. and E.A. Johnson. 1982. Distribution of prairies and solonetzic soils in the Peace River district, Alberta. Can. J. Bot. 61: 1851-1860.

Willoughby, M.G. and D. Downing. 1995. Deciduous plant communities and carrying capacity of the Boreal Ecoprovince of Alberta. Alberta Environmental Protection. Edmonton, Alta. Pub. no. T/312. 329pp.

Willoughby, M.G. 1996. The effects of grazing on deciduous plant communities in the Boreal Ecoprovince of Alberta. Proceedings of the Fifth Int'l Rangeland Congress, Salt Lake City, Utah. Vol. 1. 610-611. 

